Universidade de São Paulo

Faculdade de Filosofia, Letras e Ciências Humanas

Departamento de Antropologia

Programa de Pós-Graduação em Antropologia Social

\title{
Cosmopolíticas de crise: resistir, criar e compor mundos com as ruínas da democracia
}

Thiago Timóteo da Silva

\begin{abstract}
Dissertação apresentada ao Programa de Pós-Graduação em Antropologia Social do Departamento de Antropologia da Faculdade de Filosofia, Letras e Ciências Humanas da Universidade de São Paulo, como parte dos requisitos para a obtenção do título de Mestre em Antropologia Social.
\end{abstract}

Orientadora: Profa. Dra. Ana Claudia Duarte Rocha Marques

[ versão corrigida ]

São Paulo 


\title{
Thiago Timóteo da Silva
}

"Cosmopolíticas de crise: resistir, criar e compor mundos com as ruínas da democracia"

\author{
[ versão corrigida ]
}

Dissertação apresentada ao Programa de Pós-Graduação em Antropologia Social do Departamento de Antropologia da Faculdade de Filosofia, Letras e Ciências Humanas da Universidade de São Paulo, sob orientação da Profa. Dra. Ana Claudia Duarte Rocha Marques, como parte dos requisitos para a obtenção do título de Mestre em Antropologia Social.

Este exemplar corresponde à redação final da dissertação defendida e aprovada pela comissão julgadora em 18/11/2019.

\section{Banca examinadora:}

Profa. Dra. Ana Claudia Duarte Rocha Marques (orientadora) - Universidade de São Paulo (USP).

Profa. Dra. Carolina Parreiras Silva - Universidade de São Paulo (USP).

Prof. Dr. Jean François Germain Tible - Universidade de São Paulo (USP).

Prof. Dr. Sérgio Amadeu da Silveira - Universidade Federal do ABC (UFABC). 
Autorizo a reprodução e divulgação total ou parcial deste trabalho, por qualquer meio convencional ou eletrônico, para fins de estudo e pesquisa, desde que citada a fonte.

Catalogação na Publicação

Serviço de Biblioteca e Documentação

Faculdade de Filosofia, Letras e Ciências Humanas da Universidade de São Paulo

S586C

Silva, Thiago Timóteo da

Cosmopolíticas de crise: resistir, criar e compor mundos com as ruínas da democracia /

Thiago Timóteo da Silva ; orientador Ana Claudia

Duarte Rocha Marques. - São Paulo, 2019.

f.

Dissertação (Mestrado) - Faculdade de Filosofia, Letras e Ciências Humanas da Universidade de São Paulo. Departamento de Antropologia. Área de concentração: Antropologia Social.

1. Antropologia política. 2. Movimentos sociais. 3. Partidos políticos (processo político). 4. Internet. 5. Antropologia do digital. I. Marques, Ana Claudia Duarte Rocha, orient. II. Título. 


\section{ENTREGA DO EXEMPLAR CORRIGIDO DA DISSERTAÇÃO/TESE \\ Termo de Ciência e Concordância do (a) orientador (a)}

Nome do (a) aluno (a): Thiago Timóteo da Silva

Data da defesa: $18 / 11 / 2019$

Nome do Prof. (a) orientador (a): Ana Cláudia Duarte Rocha Marques

Nos termos da legislação vigente, declaro ESTAR CIENTE do conteúdo deste EXEMPLAR CORRIGIDO elaborado em atenção às sugestões dos membros da comissão Julgadora na sessão de defesa do trabalho, manifestando-me plenamente favorável ao seu encaminhamento e publicação no Portal Digital de Teses da USP.

São Paulo, 10/01/2020

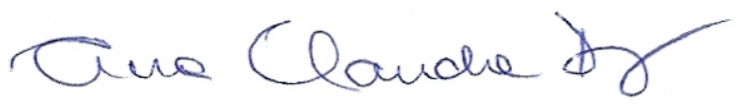




\title{
AGRADECIMENTOS
}

\begin{abstract}
À minha orientadora, a professora Ana Cláudia Duarte Rocha Marques. Obrigado pela disponibilidade, pelas indicações e pela atenção paciente e generosa.
\end{abstract}

Aos colegas membros do Hybris - Grupo de Estudo e Pesquisa sobre Relações de Poder, Conflitos e Socialidades, pelas contribuições para a primeira parte deste trabalho.

Ao Programa de Pós-Graduação em Antropologia Social (PPGAS-USP) e aos seus funcionários sempre dispostos a ajudar, especialmente à Juciele Borges pela cordialidade e solicitude.

Aos professores Carolina Parreiras e Jean Tible pelas críticas e sugestões feitas na qualificação e por terem aceitado fazer parte da minha banca de defesa. Ao professor Sérgio Amadeu por ter gentilmente aceitado o convite para fazer parte da minha banca de defesa.

Aos meus terapeutas Ella Fitzgerald, John Coltrane, Miles Davis e Zeca Pagodinho, que me acompanharam nos dias mais difíceis e sem os quais o meu caminho teria sido muito mais tortuoso.

Aos meus pais pelo apoio incondicional, carinho e compreensão.

Aos incansáveis e dedicados amigos, em especial àqueles que me incentivaram e estiveram de alguma forma presentes no decurso de minha trajetória acadêmica e do presente trabalho: Everton Medeiros, Marcelo Ramiro, Márcio Vieira, Maria Margarida (Doudou), Nilson Luciano e Otávio Mattos.

À CAPES por ter viabilizado essa pesquisa com a concessão de uma bolsa de mestrado.

E, principalmente, a todas e todos os cidadanistas que tão gentilmente me acolheram em suas vidas. In memoriam de Sônia Regina Rocha. 


\section{RESUMO}

A presente dissertação consiste em uma etnografia do movimento político Raiz -Movimento Cidadanista, com o foco em sua atuação na cidade de São Paulo. Essa associação surgiu em resposta a uma dupla percepção dos seus integrantes: a primeira é a de que o desenvolvimento do capitalismo levou a um cenário de crise (ambiental, econômica e social) de proporções catastróficas, que tem se revelado uma ameaça à própria existência da humanidade e de inúmeras outras formas de vida; a segunda é a de que as instituições políticas que marcaram o século passado não têm sido capazes de responderem a este cenário e às insatisfações dos povos e que é, portanto, preciso transformá-las. O foco desta pesquisa centrou-se no modo como os sujeitos investigados criavam formas de fazer política a partir do universo sociossimbólico que habitavam e de modelos de vida e resistência nos quais se inspiravam. A análise desse processo implicou indagar como os agentes entendiam a política e a democracia e quais eram as estratégias, os significados e os conflitos existentes na construção desse movimento político. Um aspecto que sobressaiu no exame das práticas da Raiz e que as aproximou dos levantes que surgiram no início desta década, foi o papel das tecnologias digitais na ampliação e conformação das ações de mobilização e participação social. No decurso da pesquisa, o digital passou a ocupar um lugar proeminente na compreensão dessas formas de existência política, na medida em que, visto, a priori, como mero mediador neutro da práxis política, comecei a entendê-lo como uma agência que se conecta e compõe com os sujeitos transformando decisivamente a configuração de suas práticas. Por último, este relato etnográfico é, em vários momentos, permeado por reflexões acerca das condições de realização da pesquisa antropológica e sobre o modo como o relacionamento entre pesquisador e sujeitos pesquisados incide nos caminhos e resultados analíticos.

Palavras-chave: antropologia da política; movimentos sociais; partidos-movimento; conflito; antropologia do digital. 


\begin{abstract}
The present dissertation consists of an ethnography of the Brazilian political movement Raiz - Movimento Cidadanista in the city of São Paulo. This association arose in response to two perceptions: the first is that the development of capitalism led to a crisis (environmental, economic and social) of catastrophic proportions, which has proved a threat to the very existence of humanity and countless other forms of life; the second is that the political institutions that marked the 20th century have not been able to fulfill people's expectations, which is why they would need to be reinvented. The focus of this research was on the way the subjects investigated created ways of doing politics from the socio-symbolic universe they inhabited and from the models of life and resistance in which they were inspired. The analysis of this process implied asking how the agents understood the politics and the democracy and what were the strategies, the meanings and the conflicts existing in the construction of this political movement. One aspect that stood out in the analysis of Raiz practices and brought them closer to the uprisings that emerged at the beginning of this decade was the role of digital technologies in increasing and shaping forms of participation and mobilization. In the course of the research, the digital came to occupy a prominent place in the understanding of these forms of political existence and it was no longer seen as a neutral mediator of the action of the agents, but as an agency that connects and composes with the political subjects decisively transforming the configuration of their practices. Finally, this ethnographic report is, at various times, permeated by reflections about the relationship between researcher and investigated subjects and about the conditions of fieldwork and their role in the research results.
\end{abstract}

Keywords: anthropology of politics; social movements; movement parties; conflict; digital anthropology. 


\section{SUMÁRIO}

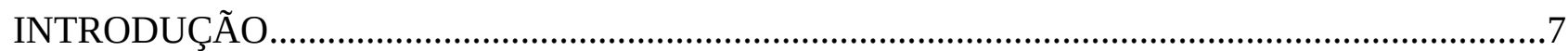

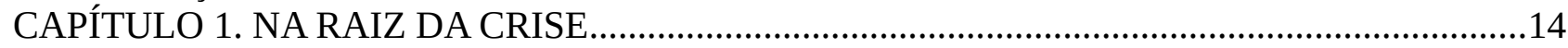

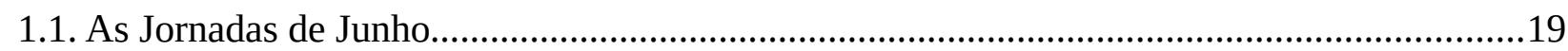

1.2. Da semente à Raiz: o surgimento da Raiz - Movimento Cidadanista.....................................23

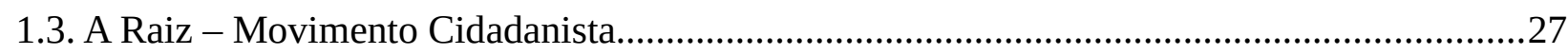

1.3.1. Bem Viver (Tekó Porã) ..........................................................................................33

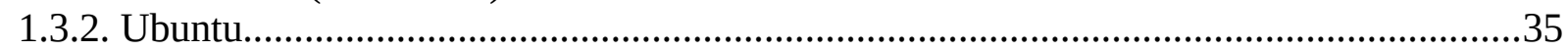

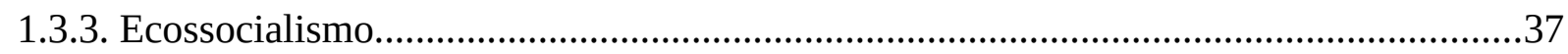

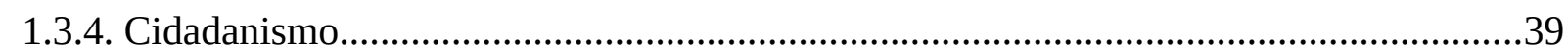

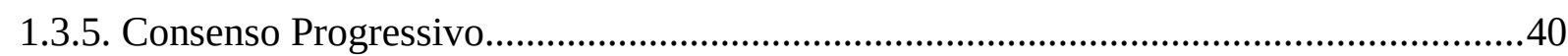

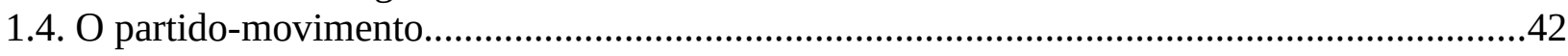

1.5. O partido em movimento.....................................................................................................

CAPÍTULO 2. DIGITALIZANDO A POLÍTICA E (COSMO)POLITIZANDO O DIGITAL..........53

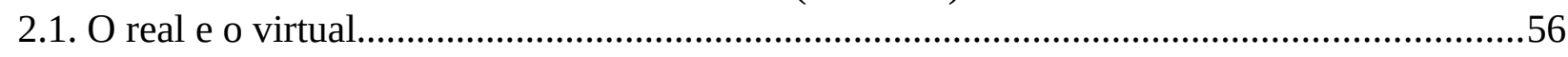

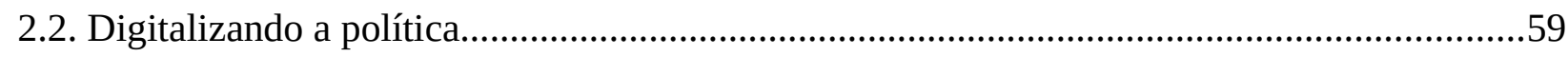

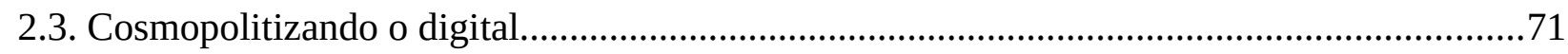

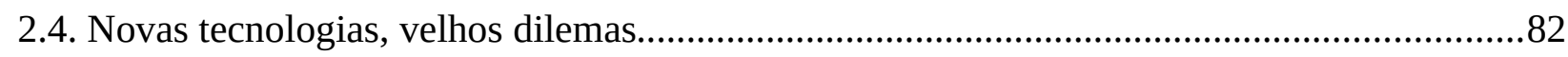

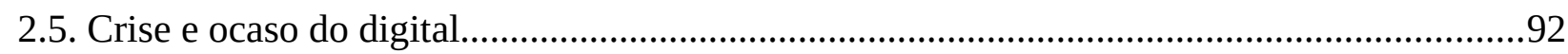

CAPÍTULO 3. FAZENDO POLÍTICA EM TEMPOS DE CRISE......................................................103

3.1. Construindo um campo...............................................................................................110

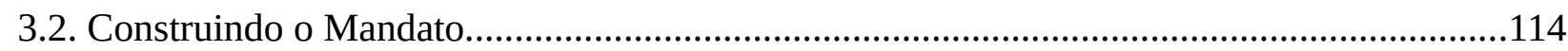

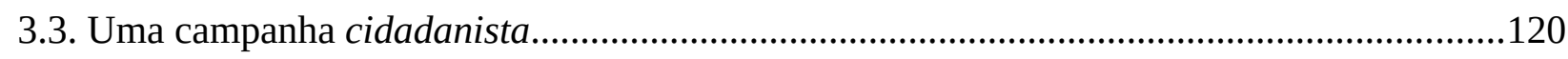

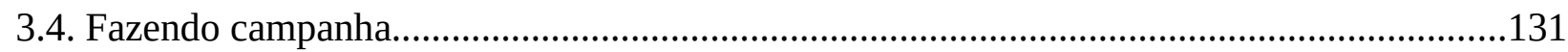

3.4.1. Fazendo campanha com WhatsApp..............................................................................133

3.4.2. Liderança e democracia na prática...................................................................................137

3.4.3. Política na comunidade..................................................................................................139

3.5. Da urgência das ruas ao sentimento das urnas.....................................................................140

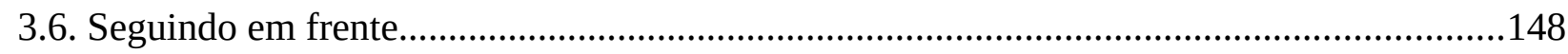

3.6.1. É na derrota que se vence uma eleição...........................................................................150

3.7. Oficina Cidadanista: de volta aos trabalhos.......................................................................155

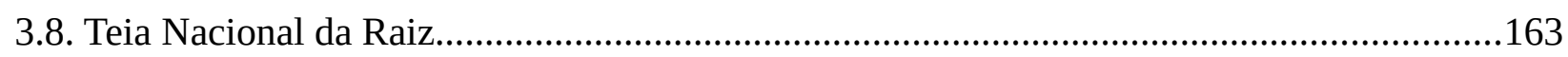

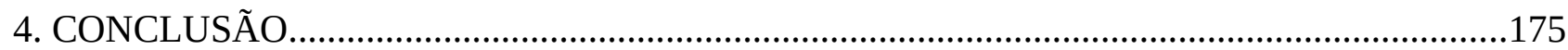

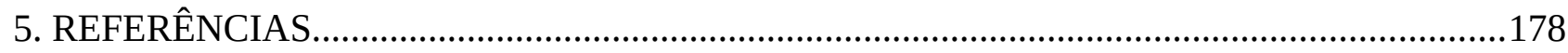




\section{INTRODUÇÃO}

\section{O que é \\ é \\ O que não é \\ é possível \\ Apenas o que não é é possível. \\ EINSTÜRZENDE NEUBAUTEN}

A recente tragédia da última eleição parece ter confirmado a célebre máxima, comumente atribuída a Walter Benjamin: "Cada ressurgimento do fascismo dá testemunho de uma revolução fracassada." Se não a levarmos ao pé da letra, essa ideia parece-me oportuna para nos fazer pensar em como a esquerda no Brasil tem sido incapaz de dar uma resposta às insatisfações de grande parte da população (que deu mostras contundentes do seu potencial disruptivo em junho de 2013), enquanto que, por seu lado, a direita obteve grande êxito em capitalizá-las e abrir-lhes uma via efetiva de expressão política. Se, por um lado, esse diagnóstico tem sido amplamente compartilhado pelas organizações e coletivos de esquerda, por outro, as dificuldades tornam-se imensas quando o que está em questão são alinhamentos que possam ir além da ideia de resistência e entrar no campo positivo da proposição de uma agenda política e econômica que enfrente os graves problemas sociais do país. Como bem sabemos, esse não é um problema que concerne exclusivamente à esquerda brasileira e podemos dizer, sem exagero, que ele aponta para um dos grandes dilemas existenciais da esquerda no mundo após o fim da guerra fria.

Com o triunfo do capitalismo, a esquerda institucional parecia cada vez mais reduzida ao papel de defensora de direitos sociais, isso quando ela mesma não assumia o protagonismo de reformas que iam no sentido oposto, como as reformas pró-mercado visando à desregulamentação das relações econômicas, com todas as consequências que bem conhecemos: privatizações, redução de direitos trabalhistas e previdenciários, sucateamento dos serviços públicos entre outras. Mesmo

1 Embora essa frase tenha sido reproduzida um sem-número de vezes, inclusive com aspas, como se fosse da autoria de Walter Benjamin, nunca encontrei a referência para a citação. Mas um colega, grande leitor de Benjamin, disseme que ela consistiria em uma síntese das reflexões benjaminianas (como na famosa frase: "os fins justificam os meios", atribuída a Maquiavel), desenvolvidas em um texto chamado Teorias do Fascismo Alemão, publicado na década de 1930. 
onde as esquerdas parlamentares funcionavam como bastiões de resistência ao avanço do capital, as crises econômicas acabaram servindo como janelas de oportunidade que abriram espaço para a destruição de direitos conquistados com o sangue e o suor de séculos de lutas. As crises tornaram aceitável o que antes seria inadmissível ou mesmo impensável, como o cancelamento de acordos firmados com sindicatos, a diminuição ou o corte de aposentadorias e de recursos destinados à assistência dos mais pobres e assim por diante. E isso tem sido possível, em larga medida, graças à separação e submissão da política (vista como o domínio do social) à economia (considerada o domínio do natural), apresentada sob o discurso do 'necessário'. Esse processo de naturalização da economia tem contado com um imenso aparato prático-simbólico que se infiltra nos aspectos mais íntimos da vida dos sujeitos e que é mantido, em larga medida, pelas alianças e articulações entre economistas, políticos, empresários, meios de comunicação, agências de publicidade, universidades, entre outros. Mas nas últimas décadas temos visto que, ao mesmo tempo que os ciclos de crise do capital abrem caminho para o avanço das políticas neoliberais, eles também têm possibilitado a emergência de formas de mobilização que vão além da mera ideia de resistência reativa e desafiam as 'restrições do real' sedimentadas pela ideologia de mercado, ao mostrarem que outro mundo é possível. É nessa chave que podemos pensar os levantes altermundistas, que tiveram início no final do século passado, as ocupações e acampamentos em espaços públicos, os movimentos insurrecionais indígenas e o próprio modo de existência de inúmeras comunidades indígenas e camponesas, que nos dão mostras de que é possível 'fazer-mundos' a partir de outras lógicas que não aquelas que governam a expansão destrutiva do capitalismo.

Esta década tem sido marcada por uma reconfiguração radical da esfera da ação coletiva, impulsionada pela potência revolucionária das novas tecnologias digitais que, além de aproximarem os agentes e operarem uma abertura sem precedentes no campo do possível, têm contribuído para produzir mudanças significativas nos modos de pensar a política e as práticas democráticas. Essa nova etapa da revolução digital não apenas aprofundou o senso de ilegitimidade e obsolescência associado às instituições políticas, como tornou pensável, após décadas de resignação e desesperança, uma revolução popular sem as consequências traumáticas dos levantes revolucionários do século precedente. Uma revolução pensada cada vez menos em termos da alternativa Estado/não-Estado (cuja premissa é a ideia de que a forma-Estado é unívoca e imutável) do que a partir da visão de que é possível (e preciso) transformar o modo de funcionamento do Estado. Inúmeras experiências políticas que surgiram no mundo após a crise de 2008 parecem caminhar nessa direção e o Podemos - agremiação partidária surgida na Espanha em decorrência 
dos levantes populares de 2011 - tornou-se paradigmático com seu modelo partidário que tem proposto superar o abismo entre a representação político-institucional e a sociedade civil. $\mathrm{O}$ conceito de partido-movimento (Boaventura de Souza 2014), reinventado a partir da experiência espanhola, tem sido uma espécie de conceito-chave para construção de novos partidos políticos ou mesmo para a rediscussão e reformulação de várias organizações e coletivos ao redor do mundo. Esse é o caso da Raiz Movimento Cidadanista, coletivo que surgiu em consequencia das manifestações que tomaram as principais capitais do país em 2013 e cuja trajetória política eu pude acompanhar de perto no decurso do ano de 2018 até o início deste ano.

Buscando oferecer uma saída política ao descontentamento e ao sentimento anti-institucional da população e inspirada na ideia de partido-movimento, a Raiz se constituiu em 2014 a partir da iniciativa de egressos do partido político em formação Rede Sustentabilidade - a primeira tentativa desses agentes de criar uma instância política conectada com as vozes de $2013^{2}$. Antes de prosseguir, convém advertir que a ideia muito corrente (divulgada em vários veículos de comunicação) de que a Raiz seria uma dissidência da Rede consiste em uma simplificação um tanto grosseira do modo como foi constituído o movimento, pois desconsidera a multiplicidade de conexões e composições (muitas delas temporárias) e as trajetórias das pessoas que compuseram o movimento e contribuíram para a sua conformação ao longo do tempo. Não se pode desprezar o fato de que o Movimento Cidadanista foi constituído graças à colaboração de inúmeras pessoas que, nem fizeram parte da Rede, nem chegaram a fazer parte da Raiz, pois tinham deixado o coletivo antes mesmo da sua fundação. Mas muitos destes que ficaram, por assim dizer, no meio do caminho, imprimiram características marcantes ao movimento por meio das múltiplas relações estabelecidas no âmbito dos espaços digitais do coletivo.

A presente pesquisa foi resultado direto do meu envolvimento pessoal nas manifestações de 2013 e do meu interesse nos desdobramentos políticos que levaram o projeto da Rede a adquirir importância no cenário nacional. Eu acompanhei o processo de formação da Rede por meio da rede social digital Facebook e dos meios de comunicação tradicionais mas, logo no início, eu já nutria certa desconfiança por conta da sua presença constante na grande mídia e, sobretudo, em relação à sua hesitação em assumir um posicionamento no espectro político-ideológico. Essa indefinição da Rede também levou a um crescente desgaste interno e o seu alinhamento com a candidatura da centro-direita (PSDB) no segundo turno das presidenciais de 2014 foi a gota d'água para alguns dos

2 Ainda que a Rede tivesse começado a ser formada bem antes do mês de junho, era bastante evidente nas declarações dos seus idealizadores que a iniciativa recebeu um novo e poderoso impulso após a eclosão das manifestações, com efeitos decisivos em suas práticas e no seu projeto político. 
seus membros-fundadores abandonarem a associação e seguirem adiante com seu projeto político em um novo arranjo coletivo. $\mathrm{O}$ curioso é notar que a coincidência entre o meu descontentamento e a insatisfação desses ativistas com os rumos da Rede foi o que fez com que os nossos caminhos se cruzassem, me levando a acompanhar, desde o princípio, a trajetória do coletivo - motivação muito semelhante a que me levou a seguir a trajetória da Rede meses antes. Foi em um site sobre política onde tomei conhecimento de que os egressos da Rede tinham formado um outro movimento e bastou procurar Coletivo Avante no Facebook para que eu me conectasse ao coletivo e passasse a seguir os seus passos até sua transformação em Raiz. Desde o princípio, portanto, a minha relação com a Raiz se deu em virtude de afinidades políticas e de uma curiosidade intelectual que, no fundo, são praticamente indiscerníveis, o que, longe de me parecer um problema epistemológico, foi o que tornou possível a presente investigação.

O que o leitor verá a seguir não será uma radiografia da Raiz Movimento Cidadanista, aliás, já me parece bem assentado que qualquer tentativa de descrição objetiva do fenômeno humano está de saída fadada ao fracasso. A proposta desta pesquisa foi bem mais modesta e consistiu, sobretudo, em tentar criar condições para que as práticas desses agentes pudessem apontar para outras possibilidades de existência política e, portanto, problematizar e, quem sabe, deslocar as categorias com as quais estamos acostumados a pensar as nossas práticas políticas. Trata-se, portanto, menos de descrever as formas de pensar dos membros do Movimento Cidadanista do que empreender um esforço intelectual para pensar com eles, ou melhor, a partir deles. Isso quer dizer que o que escrevo nas páginas que seguem é, antes de tudo, fruto da minha própria perspectiva, deslocada pela convivência com as perspectivas e os modos de fazer política dos cidadanistas. E isso implica admitir o fim do monopólio do pesquisador na construção do conhecimento antropológico e reconhecer que os meus interlocutores também elaboravam teorias que orientavam e sustentavam as suas práticas políticas e que, não raro, as submetiam ao escrutínio crítico e à experimentação. Tendo em vista que a minha abordagem se situa no interior de uma perspectiva etnográfica, evitei pautá-la pela literatura especializada, embora tenha dialogado com distintas linhas teóricas, mas, sempre que possível, partindo de questões e de modos de engajamento analítico sugeridos pelo próprio material etnográfico.

Por fim, o desafio de levar a sério a articulação entre heterogêneos obrigou-me a reconhecer a imanência do conflito e fez com que eu prestasse atenção nas recalcitrâncias, divergências e desacordos entre os agentes, o que afastou minha abordagem de uma tendência ainda muito persistente na Antropologia para ignorar e subestimar as incongruências e as múltiplas vozes 
dissonantes em proveito da coerência interpretativa. Estou com a maioria dos meus colegas antropólogos quando afirmam que inconsistências e lacunas no material não se devem a uma suposta incapacidade dos sujeitos investigados de perceberem contradições em suas práticas sociais. Mas também penso que é preciso tomar cuidado com algumas soluções fáceis e muito comuns que reduzem tais inconsistências à obsessão dos antropólogos por totalidades coesas ou a modos específicos dos sujeitos pesquisados conceberem o mundo. É preciso estarmos sempre atentos a outras possibilidades e o que as práticas dos meus interlocutores mostraram é que as contradições e as divergências não apenas podem ser reconhecidas enquanto tais, mas que sua explicitação e sua colocação como uma questão para reflexão coletiva podem ser o ponto de partida para engendrar outras práticas e outros agenciamentos coletivos.

No primeiro capítulo ( $\mathrm{Na}$ Raiz da crise) apresentarei alguns elementos que compõem o cenário de crise contemporâneo e que, de algum modo, se relacionam com a emergência e a configuração do Movimento Cidadanista, além de destacar alguns dos simbolismos e referenciais conceituais e políticos acionados em suas práticas. O tom catastrofista adotado nesse capítulo foi inspirado em um senso de urgência que, de algum modo, sempre esteve presente entre os cidadanistas e em certo espírito apocalíptico que marcou profundamente o final do período eleitoral e que se mostrava muito claramente no compartilhamento de notícias, memes e comentários a respeito dos primeiros meses do governo Bolsonaro. Não se trata, então, da subordinação ou do enquadramento do meu material etnográfico a um contexto mais amplo que o determinaria e o tornaria inteligível, pelo contrário, ficará claro na sequência do texto que as práticas dos agentes geravam as suas próprias determinações e, de certo modo, os seus próprios contextos, os quais eram incessantemente criados e recriados, mesmo que os sujeitos buscassem, muitas vezes, aproximá-las de narrativas de caráter mais abrangente.

O segundo capítulo (Digitalizando a política e cosmopolitizando o digital) será dedicado a uma análise das práticas da Raiz em meios digitais, com o foco no seu espaço na plataforma digital Loomio, que ocupou lugar central nas práticas do coletivo nos seus primeiros anos. O digital que, a princípio, seria apenas um mero intermediador ou, dito de outro modo, um cenário inerte para as ações entre sujeitos humanos, passou a adquirir centralidade analítica na medida em que parecia incidir direta e diferencialmente nos modos de fazer política do coletivo.

O terceiro e último capítulo (Fazendo política em tempos de crise) terá como foco principal a articulação dos cidadanistas em torno de uma proposta de candidatura coletiva à Câmara Federal, tendo como candidato oficial (nome na urna) um dos fundadores do Movimento Cidadanista, Célio 
Turino, e abrangerá desde o período anterior à campanha (pré-campanha), em 2018, até alguns meses após a eleição, já em 2019. O capítulo terminará com os encontros de reavaliação e reestruturação da Raiz visando à retomada de suas atividades em âmbito nacional e à redefinição de sua relação com o meio político-partidário.

A realização desta pesquisa e o resultado aqui apresentado foram orientados por diretrizes éticas estabelecidas no decurso do desenvolvimento histórico da investigação antropológica e que se encontram resumidas no Código de Ética da Associação Brasileira de Antropologia, principalmente no que se refere aos "direitos das populações que são objeto de pesquisa a serem respeitados pelos antropólogos e antropólogas" ${ }^{\prime 3}$. Em muitos momentos evitei revelar nomes para que as pessoas citadas não se constrangessem ou corressem o risco de ficarem em más relações com outros integrantes do coletivo. Isso é especialmente o caso do capítulo 2, onde optei por trocar os nomes dos cidadanistas por pseudônimos, em virtude da recorrência de várias situações atravessadas por tensões nas quais a identificação dos envolvidos poderia causar-lhes algum tipo de desconforto. Além disso, na plataforma digital não era raro que referências a declarações pregressas de alguns cidadanistas gerassem algum desgaste ou trouxessem à tona velhos conflitos, risco que eu creio ter praticamente eliminado com a substituição dos nomes. Em certas ocasiões, o esquecimento parece ter cumprido um papel tão importante quanto a memória, em outras, e a minha interferência indevida nessa dinâmica memória-esquecimento poderia ter consequências, no mínimo, inconvenientes.

Por último, quero chamar a atenção para o caráter profundamente experimental do meu empreendimento etnográfico, que se mostrará de forma marcante no decurso dos três capítulos que compõem esta dissertação. Em muitos sentidos, a experimentação é inerente à prática etnográfica e pode acontecer, por exemplo, quando o pesquisador utiliza a transformação de si mesmo, propiciada pelo encontro etnográfico, como fonte de insights e conhecimento; ou quando ele 'experimenta' os seus conceitos no campo para ver 'o que pode acontecer com eles'. Mas aqui a experimentação também pode ser estendida às estratégias analíticas adotadas para darem conta das especificidades dos fenômenos estudados, especialmente no capítulo 2. Pois se é sempre possível afirmar que todo campo etnografado é único - e, nesse sentido, nunca deixaria de ser uma novidade para o analista -, parece que alguns campos desafiam a sua capacidade analítico-descritiva mais do que outros. Esse foi o caso, por exemplo, do meu esforço em descrever e analisar as práticas políticas dos cidadanistas em um software para criação e edição de planilhas, como veremos mais à frente. Só

3 Disponível em <http://www.portal.abant.org.br/codigo-de-etica/>. Acesso em: 26/10/2019. 
muito recentemente o digital começou a ocupar um espaço relevante na Antropologia (ao menos na Europa e nos Estados Unidos) e a proliferação de perspectivas e abordagens é realmente impressionante, não apenas em razão do desenvolvimento recente do digital como campo de estudos, mas, ao que parece, por conta de suas próprias especificidades e dinâmicas de transformação. Em relação às práticas da Raiz nas quais o digital parecia cumprir um papel secundário (especialmente em um período de fortes críticas às relações virtuais), as dificuldades não foram menores, na medida em que os cidadanistas propunham, fundamentalmente, experimentos políticos deliberados, visando a subverter as formas estabelecidas (com suas regras formalizadas e classificações) de fazer política, embora admitissem, contudo, não superá-las por completo. Isso ajuda a entender como dentro de uma discussão sobre um modo de gestão compartilhada pôde ganhar relevo propostas como a de um modelo empresarial para condução da Raiz. Por isso, em certos momentos, os capítulos a seguir poderão dar a impressão de que havia em curso um processo radical de transformação de práticas e conceitos, ao passo que, em outros, ficará a sensação de que toda mudança e fluidez eram contrarrestadas por princípios e dispositivos que promoviam a estabilização e a cristalização de formas e que remeteriam, em última instância, às mesmas premissas ontológicas que sustentam as instituições políticas que eram objeto de contestação. Mas esse não me parece ser um problema que diz respeito apenas ao modo de viver a política dos cidadanistas, pelo contrário, ele tem acompanhado a Antropologia já há muito tempo, uma disciplina que, a despeito da sua inclinação pós-estruturalista pela diferença, pelos fluxos e pelas errâncias, depara-se, não raro, com a semelhança, com a rigidez e com as paragens que, muitas vezes, são tratadas como resíduos incômodos que não mereceriam maior atenção. 


\section{CAPÍTULO 1. NA RAIZ DA CRISE}

I am not proposing a return to the Stone Age. My intent is not reactionary, nor even conservative, but simply subversive. It seems that the utopian imagination is trapped, like capitalism and industrialism and the human population, in a one-way future consisting only of growth. All I'm trying to do is figure out how to put a pig on the tracks.

— Ursula K.Le Guin

É imagem comum no imaginário apocalíptico do nosso tempo a ideia do fim do mundo como consequência de um evento catastrófico que, de forma quase instantânea, põe fim a toda humanidade. Mais recentemente uma variação simetricamente inversa do mito tem ganhado força: nela, parte da humanidade sobrevive ao grande cataclismo, mas precisa aprender a viver em um mundo arrasado e sem vida. Podemos encontrar nas artes de modo geral e, especialmente, na literatura e no cinema, várias recorrências dos temas do "mundo-sem-nós" e do "nós-sem-mundo", como nos blockbusters Melancholia, de Lars von Trier, e Mad Max, de George Miller (DANOWSKI; VIVEIROS DE CASTRO 2014).

Se, por um lado, essas novas e impressionantes mitologias contemporâneas colocam na ordem do dia do imaginário social, a possibilidade de um acontecimento catastrófico de dimensão planetária, por outro, elas também mostram a necessidade de pensarmos outra possibilidade, que se escancara cada vez mais diante de nós: a de que o apocalipse pode ocorrer de forma gradual e, mais do que isso, a de que provavelmente já esteja acontecendo. Se, há poucas décadas, éramos assombrados com a possibilidade do holocausto nuclear, não deveria ser menos preocupante o fato de que todos os dias o calor equivalente à explosão de quatrocentas mil bombas atômicas se acumula no planeta, algo como 2.115.122.800 bombas de Hiroshima, desde 1998 até o presente (dia 12 de junho de 2019, às $14 \mathrm{~h} 32)^{4}$. Estamos diante de uma curiosa e espantosa convergência que coloca em relação os discursos escatológicos de inúmeros coletivos indígenas ao redor do planeta com os modos de conhecimento que conformam as sociocosmologias euro-americanas. E se o

4 Para informação atualizada em tempo real acessar o site http://4hiroshimas.com. 
aquecimento global é apontado hoje como a maior ameaça à continuidade da vida na terra, o desequilíbrio em outros processos biofísicos pode ser igualmente ameaçador. A acidificação dos oceanos, a depleção da camada de ozônio, a poluição, o esgotamento do solo e das fontes de água doce e a eliminação da biodiversidade, têm sido relacionados pelos cientistas como grandes fatores de risco para a manutenção da vida (ROCKSTRÖM 2009).

A humanidade, antes vista como sujeita aos caprichos de uma natureza que em larga medida lhe seria exterior, agora é elevada à condição de potência geológica: estamos no Antropoceno. Mas sabemos muito bem que esse antropos diz respeito a uma humanidade muito específica, um modo particular de existência que surgiu há pouco menos de trezentos anos e que, no entanto, tem sido naturalizado como único caminho possível para os coletivos humanos. Partindo do reconhecimento de que o capitalismo industrial é a grande força por trás das drásticas mudanças planetárias das últimas décadas, muitos críticos do Antropoceno defendem que o termo Capitaloceno (MOORE; PARENTI 2016) seria mais adequado para definir a era em que o Capital reina soberano. Seja como for, vale destacar que a ideia de que os humanos se tornaram uma força dominante radica fortemente em uma lógica de separação em tipos e espécies (POVINELLI 2016), a partir da qual se constituíram os grandes paradigmas da ciência (e, nesse caso, a geologia) e que remete ao dualismo metafísico natureza/cultura - um dualismo bastante instável, é importante dizer -, sobre o qual a Antropologia tem se debruçado nas últimas décadas, explorando as suas mais profundas implicações.

Foi a partir das lutas políticas dos anos 1960, sobretudo com a visibilidade conquistada por sujeitos políticos até então praticamente invisíveis, que a manutenção dessa dualidade se mostrou problemática e insustentável. Nesse cenário, o Antropoceno foi, a um só tempo, efeito e causa da erosão dessa oposição e de todos os dualismos que nela parecem estar enraizados - inclusive, a separação quase axiomática entre e a vida e a não-vida (POVINELLI 2016) -, com ressonâncias na reconfiguração da crítica social, na operação dos mercados, na governança dos Estados e grandes corporações, na geopolítica internacional e por aí vai. Sendo assim, milhões de milhões de toneladas de $\mathrm{CO}_{2}$ e $\mathrm{CH}_{4}$ estão nos obrigando a repensar e politizar os nossos constructos artificiais que separam gases atmosféricos, parlamentos, laboratórios, taxas de juros... É a inserção deliberada da política no mundo e do mundo na política que nos permitirá conter a expansão da máquina de destruição capitalista e atenuar o efeito devastador da iminente catástrofe planetária ou, ao menos, possibilitar-nos viver em um mundo arruinado. 
Stengers retoma a hipótese Gaia de James Lovelock e Lynn Margulis, na qual a Terra é pensada como uma entidade viva e em constante transformação e que é constituinte e constituída na interação com outros entes. Nesse sentido, como sugere Latour (2015:89), não estamos na atmosfera, mas "a atmosfera somos nós". Na mitologia grega, Gaia, filha de Caos, está associada à Terra e lança sua fúria avassaladora contra a tirania. Stengers propõe pensarmos o cataclismo global a partir da "intrusão de Gaia", uma irrupção raivosa e vingativa contra a tirania predatória do Capital (STENGERS 2009). A transcendência indiferente e imprevisível de Gaia impõe desafios à imagética de controle e certezas científicas da modernidade que alimentam os sonhos tecnocapitalistas de progresso e que, volta e meia, são abaladas pela devastação intrínseca aos movimentos de expansão do capitalismo. Entretanto, mais do que a resignação diante das forças que nos ultrapassam, não nos resta muito a não ser compor com Gaia para evitar a catástrofe: é preciso buscar e multiplicar alianças e alinhamentos entre as distintas entidades (humanas e não-humanas) que habitam o mundo por meio de arranjos que são,é forçoso reconhecer, bastante complexos e instáveis, o que nos remete à ação colaborativa dos hackers, aos movimentos sociais que surgiram nas últimas décadas e, - não apenas também, mas especialmente -, à diplomacia transversal dos xamãs ameríndios.

Os povos indígenas, grandes "especialistas em fins de mundo" (DANOWSKI; VIVEIROS DE CASTRO 2014:142) - por terem resistido a tantos séculos de escravidão, genocídios, etnocídios e saques de todo tipo -, podem nos mostrar como é possível viver nesse mundo em ruínas. A insurreição dos Mayas no México (1994-) é talvez o exemplo mais conhecido de que é possível resistir e viver em um mundo arrasado sem sermos capturados pelos modos de subjetivação que sustentam e promovem a barbárie capitalista. Não se trata, contudo, de um modelo a ser seguido: não há atalhos ou garantias, nem tampouco o recurso à razão universal, mas somente a evocação e invocação da potência de arranjos criativos e abertos capazes de resistir à captura por lógicas totalizantes e aparelhos centralizadores.

Os levantes do final do século passado e início deste século têm mostrado a emergência de múltiplas formas de resistência afirmativa, que vão além da denúncia e da rejeição à opressão do Estado e do Capital, produzindo novos agenciamentos e criando novas formas de ação. Se a queda do muro de Berlim figurou em boa parte do imaginário político euro-americano como o fim da história e o triunfo do capitalismo, os protestos em Seattle contra a reunião da Organização Mundial do Comércio, em 1999, representaram o retorno da política como meio efetivo de luta contra injustiças e da transformação da realidade. As manifestações nas ruas de Seattle, Praga e Gênova, na 
primeira década dos anos 2000, foram marcos no restabelecimento da esperança de que outro mundo é possível, além de apresentarem elementos que se tornariam cada vez mais característicos dos modos de ação política atuais, como: a articulação e o agenciamento de múltiplos entes (estudantes, ecologistas, trabalhadores, anarquistas, ativistas de diversos movimentos sociais e identitários, agentes não-humanos); a diversidade de modos de ação e de táticas de circulação, enfrentamento e defesa; a criação de redes de solidariedade; a ressonância entre diferentes manifestações e domínios vistos tradicionalmente como fora da esfera da política etc.

Se há algo que a crise de 2008 nos ensinou, é a lição amarga de como o Capital depende da ação deliberada dos governos para sobreviver e se perpetuar. O confisco escandaloso de trilhões do orçamento público para o salvamento de grandes conglomerados financeiros se mostrava não apenas necessário, mas inevitável diante das alternativas que pareciam configurar todo o campo do real. Resta-nos cada vez menos dúvidas de que muito da força do modelo estatal-capitalista reside em sua capacidade de definir o real, incluindo, os próprios termos que são acionados para lhe fazer oposição. Diante do cenário posto pela crise, só haveria duas alternativas: utilizar o dinheiro dos contribuintes para salvar a economia e retomar a estrada virtuosa do crescimento (com alguns sacrifícios, é claro) ou não fazer o resgate e permitir que o efeito cascata provocado pela débâcle financeira destrua o nosso modo de vida e, no pior cenário, coloque em risco a própria sobrevivência dos cidadãos. Por isso não é de se espantar que o inimigo vence até mesmo no momento de sua derrota. Seria, portanto, necessário transbordar os limites do pensável e subverter as categorias com as quais o ocidente está acostumado a pensar a política, o que parece ser o desafio a que se lançaram muitos movimentos que surgiram após 2008, seguindo a trilha aberta pelas experiências altermundistas da virada do século. As praças, marcos referenciais dessas manifestações, representam ao mesmo tempo a continuidade com o passado, como locus de encontro e do exercício da política, e um sítio privilegiado de mudanças e de redefinição do fazer político. São momentos de experiência compartilhada que promovem o encontro dos corpos e afetos e a sua inserção no coração da atividade política. As novas tecnologias digitais também têm desempenhado papel fundamental na conformação da dinâmica e magnitude dessas mobilizações incidindo, inclusive, no conteúdo político das reivindicações dos manifestantes, o que aponta para a necessidade de pensarmos o digital não apenas como um mediador neutro das relações entre agências humanas, mas como agência que se conecta e compõe com diferentes entes, transformando e sendo transformada nessas práticas. 
Ainda que me pareça razoável buscar aproximações entre as lutas populares das últimas duas décadas, não pretendo aqui isolar fatores comuns que atuariam como causas, principalmente quando se trata de eventos tão díspares como os protestos da Praça Puerta del Sol na Espanha (2011), da Praça Taksim Gezi, na Turquia (2013) ou os levantes da chamada Primavera Árabe. Essas manifestações foram o resultado de uma conjunção complexa de condições e não podem, sem prejuízo, serem reduzidas a um elenco comum de motivações. Os manifestantes turcos se rebelaram em 2013 contra a demolição do Parque Taksim Gezi e contra o autoritarismo do governo Erdogan, enquanto que os indignados do $15 \mathrm{M}$, na Espanha, protestavam principalmente contra o desemprego, contra políticas de austeridade que ameaçavam direitos sociais básicos e por uma democracia mais participativa. Não é preciso muito esforço para defender que o neoliberalismo tenha tido o seu papel na conformação de ambos os cenários de crise, o que, no entanto, não nos permite afirmar a priori que as especificidades das situações sejam apenas manifestações superficiais que escondem os verdadeiros determinantes que operam em nível mais profundo de infraestrutura econômica. Seguramente a máquina de destruição do Capital está operando nessas situações, assim como sempre esteve funcionando a pleno vapor em inúmeros bolsões de miséria e desigualdade espalhados pelo mundo sem que isso, contudo, desencadeasse a irrupção de movimentos contestatórios dessa natureza. Tão ou mais produtivo quanto comparar eventos buscando alinhá-los por suas semelhanças parece ser colocá-los em relação, não apenas por meio de suas semelhanças, mas também por meio de suas diferenças. Esse deslocamento da abordagem permite olhar para um evento a partir de outro, não exatamente do ponto de vista do outro, mas partindo da perturbação provocada pelo evento em nosso sistema de referências.

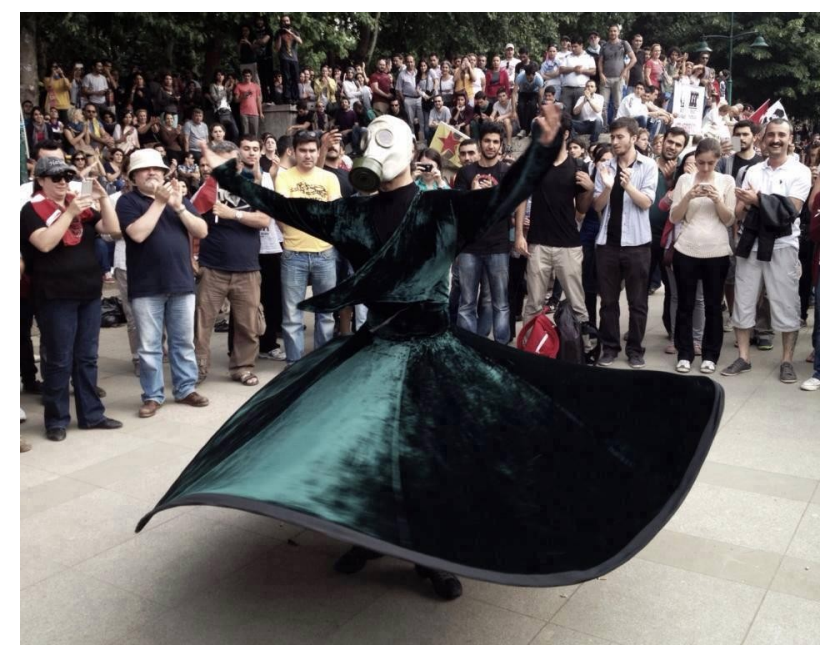

Foto1. Manifestante Sufi girando usando máscara de gás no Parque Gezi, 02/06/2013. Autor: Azirlazarus. Fonte: http://CreativeCommons, Wikimedia.org/wiki/File. 


\subsection{As Jornadas de Junho}

As Jornadas de Junho estão entre os mais impactantes acontecimentos da história política brasileira recente e têm inspirado a produção de uma extensa literatura, acadêmica e não-acadêmica. Não é meu intento passar em revista as principais abordagens analíticas e questões levantadas, nem tampouco fornecer um quadro detalhado, algo como um contexto ou pano de fundo de onde teriam surgido as práticas políticas que são objeto do presente relato etnográfico. A ideia é, antes de tudo, olhar para os levantes que ocorreram no país em 2013 partindo da experiência etnográfica e, assim, isolar alguns aspectos e tecer alguns comentários que parecem contribuir para um diálogo produtivo; trata-se, portanto, de um olhar retrospectivo que, de certo modo, realiza uma torção das análises que, partindo de um corpus literário e da comparação apressada de grandes fenômenos sociais supostamente representativos do fenômeno social em questão, tentam encaixar a realidade observada em molduras pré-formatadas.

A despeito da diversidade de interpretações, os levantes que começaram em junho e seguiram ao longo do ano de 2013 têm sido vistos como uma espécie de transbordamento, para as praças e ruas das grandes cidades brasileiras, de um sentimento de indignação coletiva cujo estopim foi o aumento das tarifas dos transportes urbanos. A insatisfação geral da população com os poderes constituídos (sobretudo em razão dos efeitos diretos da crise econômica na vida das pessoas), as novas vias de comunicação abertas pelos dispositivos digitais, a repressão policial aos manifestantes e a sua criminalização pela mídia corporativa (as duas últimas denunciadas reiteradamente nas redes sociais digitais), são elementos frequentemente mobilizados para explicar a explosão das manifestações pelas ruas de todo o país. Entretanto, é preciso ter cuidado com as narrativas sobre a emergência súbita desses levantes, pois elas tendem a deixar de lado o fato de que as lutas pelo direito à mobilidade existem e vêm se fortalecendo há bastante tempo e em várias partes do país ${ }^{5}$; e o fato do aumento na tarifa estar na origem de um movimento que se espalhou rapidamente pelo país não significa que esse aumento seja apenas causa imediata e circunstancial (como tem sido a

5 Podemos citar a Revolta do Buzu, uma onda de protestos ocorrida em Salvador, em 2003, bem como os protestos em Florianópolis em 2004 e 2005 e em São Paulo no ano de 2011, entre outros, que são sempre lembrados pelos ativistas como importantes marcos na luta pela mobilidade e grandes referências para a construção do Movimento Passe Livre (MPL-SP, 2013). Sem contar as inúmeras revoltas de não-ativistas que frequentemente irrompem em pequenas cidades de todo o país e que não ganham muita repercussão nas grandes mídias. 
tendência nos usos do termo "estopim"), mas também diz respeito a um tema central que afeta a vida de grande parte dos moradores dos grandes centros urbanos. ${ }^{6}$

Essas abordagens, por seu caráter mais sincrônico e situacional, estão mais sujeitas a uma interpretação espontaneísta das manifestações, deixando de lado tanto fatores internos (que dizem respeito à trajetória de luta do movimento até o momento que o levou a agir naquela situação), quanto as ressonâncias, as inspirações e contaminações entre distintas mobilizações e práticas políticas. E tudo indica que o advento das novas agências tecnológicas tem feito com que essas ressonâncias 'invisíveis' adquiram cada vez mais peso na conformação dessas práticas, lançando desafios analíticos consideráveis. O viés espontaneísta também tende a dar sobrepeso analítico a uma suposta efemeridade das manifestações (que surgiriam e desapareceriam subitamente), o que dificulta entender como essas lutas podem contribuir para a constituição de novas práticas e de novos sujeitos políticos coletivos. Outro grande obstáculo à compreensão dessa contribuição é a ideia de que a fragmentação e a fluidez dessas práticas são problemas a serem superados - para que elas sejam bem sucedidas politicamente - por meio da unificação, da criação de instâncias centralizadas e de caráter permanente, entre outros. Mas o que práticas de movimentos como o MPL e a Raiz pareciam indicar é que a dispersão e a fluidez eram intrínsecas aos seus modos de definir a política e a democracia, embora, em algumas situações, elas também pudessem ser concebidas de forma negativa. É necessário, portanto, precisar etnograficamente se ideias como fluidez e fragmentação são mobilizadas pelos sujeitos, o que podem significar no conjunto de suas práticas e em quais situações seriam vistas como desejáveis ou não.

Da mesma forma podemos colocar em suspeição as simplificações que atribuem a esses levantes a ausência de objetivos claros ou metas difusas. O problema é que essas análises, por operarem com muitas das categorias da democracia representativa, supõem que essas lutas devem se constituir em torno de uma lista de reivindicações enquanto o que está em jogo, muitas vezes, é a recusa geral das linhas políticas existentes (e do seu modo de operação) e a proposição de outras, que sejam baseadas em outros princípios, isto é, em outros modos de pensar a política. Não podemos também ignorar o papel das emoções na conflagração e na manutenção desses levantes, de modo que não há indicações de que seja apenas o cálculo da chance de êxito (em convencer as autoridades constituídas) que faz as pessoas decidirem sair às ruas ou a constatação puramente racional de que haveria num dado momento uma oportunidade para uma ação reivindicatória bem-sucedida. São bastante recorrentes nas análises sobre Junho, passagens que

6 Não me parece absurdo afirmar que a origem social dos analistas também deve contribuir para essa tendência analítica. 
mencionam a indignação dos manifestantes, seja diante do aumento da tarifa dos transportes, seja diante da repressão às primeiras manifestações. Deste modo, o sentimento acaba assumindo o papel de poderoso indutor da ação política sem que, contudo, seja objeto de uma atenção mais detalhada, como se, por sua própria natureza, não necessitasse de maiores explicações. Daí a sua presença tímida, (geralmente reduzida à mera menção), no início das manifestações e seu notável desaparecimento, quase que por completo, no desenrolar dos acontecimentos. Se as emoções estiveram presentes de forma discreta nas análises dos levantes de 2013, os eventos que ocorreram após junho, onde se destacaram as manifestações que desencadearam o processo de impeachment da ex-presidenta Dilma Rousseff e o período das eleições presidenciais de 2018, mostraram que já não é mais possível subestimar o efeito das emoções no âmbito da ação política. A reivindicação que aqui faço da reavaliação do estatuto das emoções na pesquisa dessas práticas políticas (para além do reconhecimento do papel circunstancial das emoções como gatilho para ação), também é consequência direta do meu trabalho de campo, onde as emoções se mostraram decisivas nas mais distintas dimensões da ação coletiva e em diversas nuances. Nele, o digital adquiriu uma importância crucial, uma vez que atuou decisivamente no surgimento, na propagação, na circulação e na conformação dos afetos. Hoje talvez já não cause tanta estranheza a constatação de que o digital está intimamente relacionado com a dinâmica dos afetos, situação bem distinta do período anterior ao advento dos smartphones, quando era muito corrente a ideia de que a ausência (ainda que relativa) de emoções era um dos traços mais característicos das interações virtuais. Nessa pesquisa optei por dar relevo à dimensão êmica das emoções, que muitas vezes está em franco desacordo com a forma como são conceituadas pela filosofia ou pela psicologia e outras ciências do comportamento. Assim, termos que em outros modos de conhecimento podem ser diferenciados, como emoções, afetos e sentimentos, nas situações em que eram acionados pelos meus interlocutores, eram tomados como intercambiáveis, embora me pareça que houvesse a predominância do uso de emoções e afetos em situações que sugeriam um maior grau de envolvimento intensivo. $\mathrm{Na}$ realidade, na maioria das vezes os sujeitos não utilizavam uma categoria mais abrangente para conceituar os seus estados emocionais, mas faziam amplo uso de termos mais específicos como raiva, ódio, medo, tristeza ou metáforas como esquentado(a) ou paralisado(a). Assim sendo, ao contrário de certa tendência psicologizante que reduz os afetos à dimensão individual, o que o campo propõe é que há um ganho analítico notável se forem entendidos e relacionados no interior das práticas e dos discursos coletivos dos agentes. 
A dinâmica da participação e articulação dos manifestantes que tomaram as praças e ruas do Brasil a partir de junho de 2013, aponta para a sintonia desses levantes com vários outros movimentos ao redor do mundo, a despeito das suas inúmeras diferenças. São formas de pensar a política que, cada vez mais, rejeitam deliberadamente a separação entre forma e conteúdo e, por isso, tendem a não aceitar que suas ações sejam organizadas ou lideradas por instituições hierarquizadas como partidos e sindicatos. Assim são dignas de profundo interesse as composições entre os diversos participantes das Jornadas como: coletivos de inspiração anarquista (Anonymous, FAG, Resistência Popular, Utopia e Luta etc.), adeptos da tática Black Block, militantes de partidos, midiativistas, estudantes, entre outros. De certo modo, esses eventos funcionaram como grandes laboratórios para experimentações políticas e essas alianças como operadores de abertura para outras composições, para outros modos de relação entre entes (incluindo as instituições formais e dispositivos tecnológicos) e para problematizar categorias que estão nos fundamentos da nossa democracia representativa. É preciso insistir na importância das ressonâncias, tanto no espaço como no tempo, por vias diretas, como, por exemplo, coletivos que se originam a partir da experiência de uma ação política, ou por vias indiretas, como no caso de coletivos que surgem a partir do sentimento de indignação gerado por um evento - mesmo que seus fundadores não estejam diretamente relacionados a essa situação. Aí o papel das redes sociais digitais e dos meios de comunicação tradicionais parece essencial. É bom ressaltar que essa distinção entre ressonância direta e indireta tem, sobretudo, valor explicativo já que, por exemplo, um sujeito que acompanha e interage com uma luta política por meio das redes sociais pode estar tão ou mais envolvido (e ser tão ou mais decisivo) do que um manifestante que vai às ruas, dependendo da situação específica e do critério considerado.

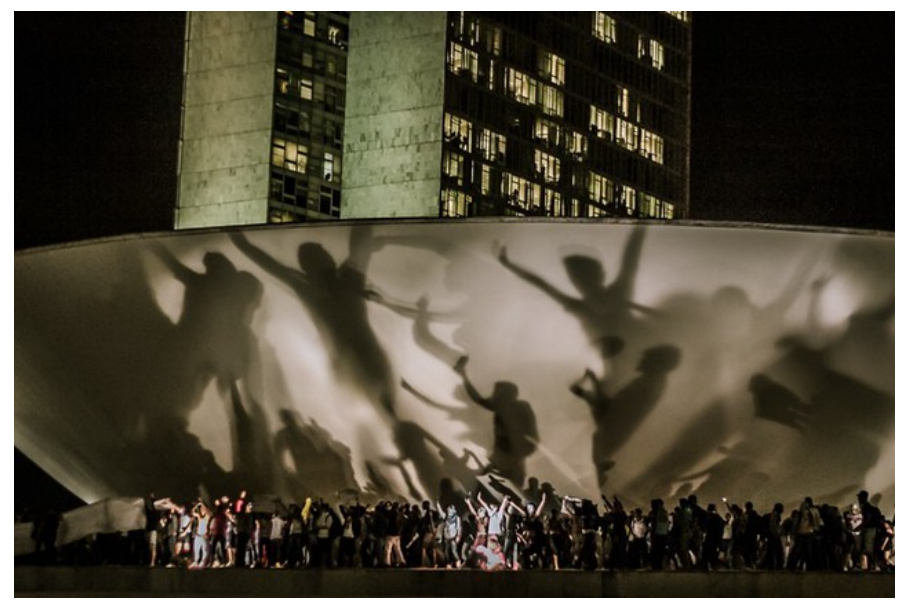

Foto2. Manifestantes ocupando a rampa do Congresso Nacional, em Brasília, no dia 17 de junho de 2013. Autor: Mídia Ninja. Fonte: $<$ https://www.brasildefato.com.br/2017/06/26/4-anos-das-jornadas-de-junho-como-a-militancia-politica-se-transformou/>. 


\subsection{Da semente à Raiz: o surgimento da Raiz - Movimento Cidadanista}

O meu objetivo aqui não é compor uma narrativa reunindo e relacionando cronologicamente um conjunto sistemático de acontecimentos para explicar o surgimento da Raiz - Movimento Cidadanista, mas apenas pensá-lo a partir de questões e dinâmicas que sempre estiveram muito presentes e que me pareceram, portanto, constitutivas do modo de existência do coletivo.

É muito corrente nas análises sobre as Jornadas de Junho, a ideia de que um dos efeitos mais importantes das manifestações foi o despertar das pessoas para a política, tirando-as de um suposto estado de apatia. Embora esse tipo de análise esteja comumente imbuída de reducionismo e preconceito - reducionismo por reduzir a política a atos de protesto e preconceito por reproduzir uma afirmação de amplo respaldo no imaginário popular, mas que é desmentida pelo fato de que a maioria dos manifestantes já demonstrava interesse pela política antes das manifestações -, Junho foi para muitos sujeitos uma espécie de porta de entrada para o protesto político nas ruas, abrindo um novo campo de possibilidades de ação e de participação política. ${ }^{7}$ Para múltiplos agentes e coletivos, Junho foi um momento de retomada e de surgimento de novas ideias, práticas, alianças e redefinição de rumos. Alguns coletivos surgiram a partir dessas manifestações embora, muitas vezes, fossem movimentos que já existiam anteriormente, mas que ganharam novo fôlego e foram se redefinindo a partir da suas participações e da reflexão a respeito do seu lugar no interior da conjuntura política que se apresentava. Muitos deles tiveram maior exposição a partir de Junho, como o próprio MPL, mas já vinham de um longo processo de amadurecimento e transformação. Esse era o caso do movimento Rede Pró-Partido, constituído meses antes das manifestações em torno da figura de Marina Silva e que deu origem, mais tarde, ao partido Rede Sustentabilidade. A iniciativa teve origem no Movimento Nova Política, criado em 2011, e que tinha como objetivo fomentar discussões sobre novas formas de fazer política. Sem entrar em maiores detalhes, não é difícil se dar conta da dinâmica complexa de formação, continuidade e constituição recíproca entre os diferentes coletivos. Ainda que seja importante levar em consideração a centralidade de Marina, se seguirmos sua trajetória e de seus correligionários desde a sua candidatura pelo Partido Verde, em 2010 (e mesmo antes, no Movimento Brasil com S, em 2007), passando pelo Movimento Nova Política (2011), Rede Pró-Partido (2013), Partido Socialista Brasileiro (2014) e Rede

7 Segundo pesquisa nacional realizada pelo Ibope, em junho, 89\% dos entrevistados afirmaram ter médio ou grande interesse pela política e $46 \%$ estavam participando pela primeira vez de uma manifestação (Fonte: IBOPE. Pesquisa manifestantes, 20/06/2013). 
Sustentabilidade (2013-), podemos ver, a despeito de linhas claras de continuidade, a dificuldade de pensar essa dinâmica a partir da ideia clássica de grupo como corpo substancial e estável, de contornos bem definidos. Embora Marina tenha sido sempre acompanhada de perto por companheiros de luta política (que já foram, inclusive, chamados de marineiros), não é possível identificar um conjunto fechado de agentes que passou por essas organizações, já que muitos saíram, outros entraram, alguns sequer se identificavam como parte de qualquer um dos coletivos, mas contribuíram para o seu funcionamento - tanto quanto ou mais do que alguns dos filiados. A natureza do vínculo dessas pessoas também variava enormemente de formação para formação: a iniciativa da Rede Pró-Partido e o vínculo com o PSB, por exemplo, tinham um caráter temporário e fins muito específicos, respectivamente, viabilizar a criação de um partido e a participação nas eleições de 2014. Ademais, a Rede nasceu a partir do Movimento Nova Política sem substituí-lo ou ser englobada por ele, mas mantendo uma relação de troca permanente e influência recíproca, até a perda paulatina de vitalidade e seu esvaziamento como um grupo digital na rede social Facebook. Chama a atenção essa presença dos coletivos nos meios digitais, que torna ainda mais problemática essa noção de grupo, uma vez que, em algumas ocasiões, não fica claro se um dado coletivo foi dissolvido ou se está apenas inativo (podendo ser reativado a qualquer momento) ou qual seria o estatuto de alguns de seus membros. Talvez seja o caso de levar a sério a hipótese de que a mera existência de um espaço em uma rede digital permite a manutenção, por muito tempo, do senso de existência de uma coletividade, ainda que não haja interação contínua entre os seus membros, o que pode ter implicações analíticas bastante relevantes.

Por isso a ideia corrente de que a Raiz foi criada por um grupo de dissidentes da Rede (EL PAÍS 2014) pode carregar consigo pressuposições que simplificam em demasia a dinâmica interna da Rede e a trama complexa que deu origem à composição da Raiz. Essa simplificação poderia, por exemplo, levar à conclusão de que o suposto grupo já funcionaria dentro do partido como uma espécie de segmento ou facção e que a suas linhas de fissão já poderiam ser identificadas em certos alinhamentos em relação a algumas discussões partidárias. Entretanto, olhando um pouco mais de perto, tal hipótese seria dificilmente sustentável. É preciso chamar a atenção para o crescente descontentamento de membros em relação a alguns temas considerados centrais, como a falta de transparência, indefinição ideológico-programática e centralização do processo decisório. $\mathrm{O}$ ápice desse descontentamento foi o apoio da executiva do partido ao candidato Aécio Neves (PSDB) considerado pela maioria representante das elites e da velha política -, no segundo turno das presidenciais de 2014, que ocasionou a saída de vários integrantes, muitos dos quais participaram 
mais tarde da formação da Raiz. Mas segundo interlocutores, esse descontentamento foi quase generalizado, não se restringindo apenas àqueles que saíram naquele momento, desgaste que continuou se aprofundando, provocando outra desfiliação coletiva em 2016 e com justificativas similares. ${ }^{8}$

A desilusão dos dissidentes de 2014 foi, contudo, acompanhada por um forte sentimento de que era preciso continuar fora da Rede, de que na sua visão da política havia uma boa resposta para o descontentamento da população com um sistema político disfuncional e corrupto. E assim, em outubro daquele mesmo ano, surgiu o coletivo Avante, nome que remete à necessidade de seguir adiante (para além da experiência malsucedida na Rede e rompendo com a política tradicional) e às lutas socialistas e anarquistas do século passado (aqui fazendo referência especial à música Bandiera Rossa, que diz: avanti poppolo, Bandiera Rossa...). O Avante reuniu não apenas os egressos da Rede, mas militantes de diversos movimentos sociais, estudantes, intelectuais, artistas, ambientalistas e pessoas sem nenhuma experiência partidária pregressa, incluindo algumas que se identificavam com o anarquismo e com correntes libertárias, refratárias à política institucional. $\mathrm{O}$ coletivo fez amplo uso das redes sociais digitais para divulgação, articulação e recepção de novos membros, modelo de atuação que depois foi continuado na Raiz. Os encontros presenciais eram reservados para decidir as questões mais importantes, mas muito valorizados por promoverem o contato face a face (questão que será discutida mais detalhadamente no capítulo II).

Embora o Avante não seja aqui objeto de exame detalhado, fica bastante claro que o conteúdo e as dinâmicas características de funcionamento da Raiz tomaram forma, em larga medida, no seu âmbito. O Avante foi concebido para a construção de uma proposta de associação política alternativa e seria dissolvido no mesmo momento do surgimento dessa associação, de modo que a relação entre Avante e Raiz é tanto de continuidade como de transformação. Não se tratou, contudo, da reunião de pessoas para a elaboração de um projeto ou modelo que se realizaria em um novo coletivo, aliás, nada mais distante do modo desses agentes conceberem a política do que essa ideia de correspondência estrita entre modelo e realidade. Trata-se, antes, de um esboço aberto e experimental, não apenas sujeito a contínuos reajustes (sem referência a um grande modelo ou verdade exterior), como fazendo destes rearranjos os motores fundamentais da dinâmica do seu modo de existência. Mas, olhando mais de perto, vemos que havia concepções diversas do que seria esse experimentalismo e que havia uma forte tensão entre um experimentalismo mais aberto e

8 Os argumentos expostos pelo antropólogo Luiz Eduardo Soares, no dia 3 de outubro de 2016, para explicar a sua saída da Rede converge de modo notável com as razões apontadas por outros egressos da Rede e pelos descontentes com os rumos do partido. A carta foi publicada no portal Justificando < http://www.justificando.com/2016/10/03/carta-aberta-aos-membros-da-rede>. Acessado no dia 23/05/2019. 
errante e um experimentalismo no qual subsistia, ainda que de forma residual, uma ideia de se tentar chegar a um modelo acabado. A fala de Alex, no espaço digital do coletivo, sobre a construção do estatuto é bastante elucidativa dessa tensão:

A ideia do Estatuto é fornecer uma organização experimental que poderá e será (assim espero) refinada até o momento da fundação do partido em si, por volta de 2017 [...] O mais importante para mim é praticar a "circularidade" [fazer os círculos funcionarem] de acordo com os princípios e é isso que devemos estimular. E, ao fundar um círculo, que se discuta em primeiro lugar os princípios e a estrutura experimental e se leve isso para o aprimoramento dos instrumentos. Todo instrumento deve ser continuamente aprimorado, incluindo os contratuais.

Alex, em sintonia com seus interlocutores, sugeriu uma contínua avaliação e transformação dos arranjos que estavam sendo criados sem, contudo, abandonar completamente a ideia de que esse processo de "aprimoramento" (que supõe um referencial) teria fim com a fundação partidária da Raiz.

A participação do digital nesses arranjos fez com que eles se tornassem ainda mais instáveis e sujeitos à reavaliação, afinal de contas, a digitalidade era vista como impregnada de imprevisibilidade e riscos. O uso da rede social digital Facebook para a escolha do nome do coletivo foi, como veremos no próximo capítulo, objeto de intenso debate sobre o modo como essa rede social promovia modos de relação que iam em sentido contrário dos princípios defendidos pelo coletivo, fazendo com que, mais tarde, o seu papel fosse redefinido no conjunto das práticas da Raiz.

O processo de elaboração do manifesto de fundação da Raiz (a Carta Cidadanista) e do seu estatuto funcionou como um importante laboratório de construção coletiva e composição de realidades com humanos e não-humanos (especificamente, os dispositivos digitais) e já evidenciavam dinâmicas constitutivas e constituintes da Raiz. Em março de 2015, o coletivo Avante passou a se chamar Raiz - Movimento Cidadanista e, diante do entendimento comum da necessidade de atuação na arena política institucionalizada, apresentou-se como partido político no Fórum Social Mundial, em Porto Alegre, em janeiro de 2016 - embora a legalização não viesse a se concretizar como veremos no capítulo 3. O Movimento Cidadanista se constituiu em larga medida em torno de princípios, práticas e pautas defendidos nos levantes socialistas e anarquistas do século passado e naqueles que marcaram as crises das últimas décadas. As lutas antiglobalização da década de 1990, as mobilizações que tomaram as praças e ruas do mundo após a crise de 2008 e, 
principalmente, as manifestações das Jornadas de Junho, a resistência dos povos indígenas, as experiências políticas do municipalismo catalão, do Podemos espanhol e do grego Syriza, eram referências constantemente reivindicadas como inspiração e, de certo modo, balizadoras das ações do coletivo. Os modos de existência e de resistência dos povos indígenas inspiraram a adoção dos princípios fundadores do coletivo expressos na Carta Cidadanista enquanto que os ideais de participação, autonomia e horizontalidade, caros a coletivos libertários, pesaram decisivamente na avaliação e na escolha da plataforma digital do coletivo. Não podemos mais menosprezar essas influências ou reduzi-las à mera menção, como tem sido a tendência hegemônica nesse tipo de análise. Fica cada vez mais evidente que essas influências podem ter efeitos nada triviais e, por isso, precisamos saber até que ponto e de que forma essas experiências ressoam umas nas outras e como podem se constituir mutuamente, reconhecendo, é claro, que elas são transformadas já no momento em que são tomadas como objeto de reflexão pelos agentes. A segunda parte será dedicada a uma apresentação da Raiz Movimento Cidadanista em diálogo com os seus princípios fundadores e as suas definições estatutárias. Ficará claro que a Raiz é o resultado de um lento e intrincado processo de composição coletiva que reúne ideias e práticas heterogêneas e de uma rica reflexão política e conceitual.

\subsection{A Raiz - Movimento Cidadanista}

No dia 8 de março de 2015, dia da mulher, estudantes, intelectuais, artistas e ativistas de várias causas, reunidos em São Paulo, oficializaram a existência da Raiz - Movimento Cidadanista e lançaram a Carta Cidadanista, contendo os princípios que inspiravam a construção da Raiz, como as ideias de Bem Viver ou Teko-Porã (de inspiração ameríndia), Ubuntu (de origem africana), Ecossocialismo (de origem europeia) e Consenso Progressivo, além de delinear as bases de sua organização como partido-movimento. A seguir faço uma breve apresentação dos simbolismos constituintes da Raiz e, em seguida, apresento um resumo dessas quatro ideias-conceito, dando relevo aos significados mobilizados com mais ênfase nas práticas coletivas cotidianas.

Como dito anteriormente, o nome Raiz - Movimento Cidadanista foi escolhido após enquete realizada na rede social Facebook e a decisão final tomada na reunião nacional pelos participantes (presenciais e online). Na verdade, houve uma articulação da escolha (no seu sentido mais usual de seleção das opções mais votadas de uma lista) com um processo de construção conjunta (que 
incluiu a interlocução, a avaliação e o refinamento) que levou ao nome definitivo. A análise desse processo revelou os sentidos do termo Raiz para os participantes, alguns dos quais continuamente reivindicados e reafirmados. Nos discursos dos meus interlocutores o termo evocava imediatamente significados que remetem a:

1. Ideia de origem (ancestralidade): que vai ao encontro do desejo coletivo de resgate das raizes identitárias que formaram o país (europeia, indígena e africana) e que, sobretudo no caso das duas últimas, foram sempre consideradas de status inferior e silenciadas;

2. Noção de fixação e fundamentos sólidos: a Raiz reconhecia como condição sine qua non da sua existência o enraizamento na sociedade (o que, em sua visão, não existiria na grande maioria dos partidos), por isso havia o pensamento persistente de que a constituição do coletivo como partido político levaria tempo e que deveria ocorrer sem atropelos, poderia nem mesmo acontecer.

3. Ecologia: a Raiz é a metáfora, por excelência, da ligação com a terra, a base que sustenta a vida. A ecologia, nessa concepção, não se restringia aos modelos das ciências naturais e, muitas vezes, adquiria um sentido, não expressamente formulado, de uma organização do cosmos baseada em um equilíbrio entre os seres e que o distanciamento da humanidade em relação à natureza fez com que esse equilíbrio fosse seriamente comprometido. Existia uma noção difusa de um fluxo energético ligado a esse equilíbrio e de que o contato com a natureza e, sobretudo com a terra, promoveria a reconexão da humanidade com essas energias, enquanto que a perda desse contato seria a causa de inúmeras modalidades de degradação físico-espirituais (doenças, estresse, tristeza, descontrole emocional etc.). As práticas rituais realizadas no início ou no encerramento de alguns encontros (sobretudo as reuniões mais ampliadas) faziam referência principalmente à conexão com a terra, ao recarregamento e troca de boas energias e ao sentimento de união dos presentes. Em sua maioria, essas práticas consistiam em dinâmicas de grupo em que os participantes se conectavam pelas mãos formando um círculo e experimentam movimentos em ritmos sincronizados (como em uma dança circular), às vezes acompanhados de vocalização conjunta ou cadenciada. Os participantes, geralmente quando se referiam a essas práticas, falavam em realização de uma mística, mas elas já foram definidas em termos mais específicos, como troca de energia telúrica.

O simbolismo da terra, não raro, também estava associado a uma simbólica da feminilidade e dos predicados subsumidos nessa ordem, embora essa associação não estivesse isenta de tensões. Era relativamente comum nas falas de meus interlocutores a ideia de que nossas raízes estariam fincadas na ordem feminina e materna da natureza, inclusive, em uma das minhas primeiras idas a campo, Mateus me perguntou se, como antropólogo, eu saberia dizer se as primeiras sociedades 
eram matriarcais. A Terra (referida, às vezes, como mãe-terra em alusão à Pachamama) costumava estar relacionada à fertilidade, à maternidade, à união e ao cuidado, por um lado, e à resiliência e à potência, por outro, características também atribuídas ao feminino em algumas ocasiões. Assim se pode compreender melhor a convenção de se referirem à Raiz, nunca em concordância com o masculino de partido (que remeteria à divisão), mas sempre no feminino, denotando a "inteireza" (CARTA CIDADANISTA:47). Se havia uma constante comportamental inflexível na Raiz era a de que se alguém começasse a frequentar as reuniões e dissesse 'o Raiz' (com artigo definido masculino), a sua fala seria, tão logo percebida, automaticamente corrigida. A força do simbolismo de gênero se apresentava de forma muito clara nos significados atribuídos à participação da deputada federal Luíza Erundina na formação da Raiz. Erundina foi, por algum tempo, a maior referência do coletivo e embora, normalmente, não atuasse diretamente (em questões executivas e deliberativas), fazia uso do seu prestígio político para promover (alavancar) a imagem da Raiz, embora a indefinição a respeito do seu lugar no coletivo tenha sido objeto de muita discussão interna. Houve um notável processo de identificação de atributos associados à parlamentar com o imaginário da Raiz, como a sua feminilidade, profundamente ligada à força (de caráter e princípios), resiliência (o exemplo da mulher pobre do nordeste do país que venceu no sul) luta (vida dedicada à ação e militância política) e ao cuidado, quase maternal (de quem sempre olhou pelos mais pobres). A sua ancianidade (vista como deliberadamente assumida e reivindicada pela manutenção dos seus cabelos brancos) também era, não raro, interpretada como uma personificação do simbolismo de origem da Raiz. Essa identificação profunda entre a Raiz e a parlamentar se expressava nas referências à Erundina como a grande jardineira, nossa guerreira e até mesmo matriarca. É importante esclarecer que essa centralização na imagem da parlamentar ia contra a visão geral de que a Raiz deveria atuar contra o personalismo (um dos grandes males da velha política) e essa contradição não deixava de ser observada e criticada por alguns, às vezes em termos bastante enfáticos, como na reclamação de Luiz Paulo a respeito de uma desmedida glorificação e endeusamento de Luíza.

A discussão na plataforma digital sobre os significados do Triskle Celta, que constituiu o símbolo da Raiz, mostrou mais concretamente como o simbolismo do feminino esteve, desde o começo, carregado de importância e tensões. O símbolo foi formado pela imagem negativada do Triskle Celta no interior de um círculo. As espirais celtas foram encontradas em inúmeros artefatos e monumentos pré-históricos, embora com muitas variações na forma da representação. A palavra Triskle significa, literalmente, três pernas e, de fato, pode-se ver na imagem a sugestão de 
três pernas correndo ou, numa outra perspectiva, três pontas curvilíneas que fazem referência ao movimento contínuo da vida e do universo. A seguir reproduzo a primeira versão do texto sobre a identidade visual da Raiz que sintetiza alguns dos seus significados:

Associado aos quatro elementos básicos da natureza - a terra, o fogo, o ar e água -, o triskle celta é o símbolo que sintetiza toda a sabedoria desse povo. Ele representa as três faces da mulher, considerada a expressão máxima da natureza: a anciã, a mãe e a virgem. Usado como talismã, esse objeto atrai as três principais qualidades femininas - ou seja, a intuição, a ternura e a beleza - e ajuda a obter proteção contra todos os males. A divindade relacionada a esse talismã é a própria natureza. A cor marrom do símbolo representa a terra.

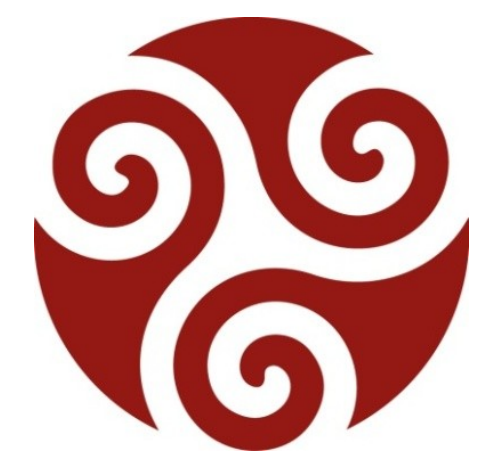

Fig.1. Símbolo da Raiz - Movimento Cidadanista: imagem negativada do Triskle celta dentro de um círculo com a cor marrom simbolizando a terra.

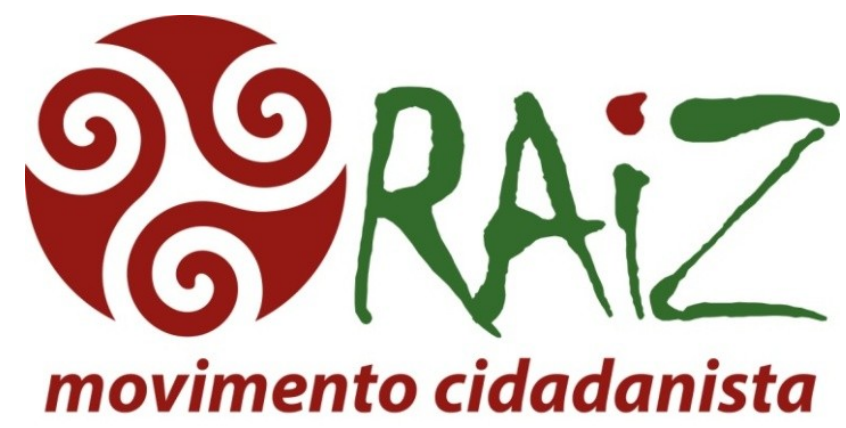

Fig.2. Símbolo Misto (predominantemente horizontal) da Raiz-Movimento Cidadanista. É misto, pois é composto por: 1.símbolo (o triskle). 2. logotipo (o nome estilizado Raiz em verde, em fonte Chiller, representando a natureza - em sua naturalidade e beleza quase artística - com a estilização de um ponto acima da letra i, na cor marrom, representando o fruto); 3.assinatura (movimento cidadanista em letras minúsculas na cor marrom, deixando o destaque para o nome Raiz.) 
Três mulheres se manifestaram em discussão online contra os significados veiculados pelo símbolo, segundo elas, profundamente radicados em um essencialismo sexista, descontentamento expresso enfaticamente na manifestação de Sandra:

Vemos aí que a mulher é tratada de forma totalmente sexista. As três fases da vida - jovem, adulta e anciã - são vistas apenas do ponto de vista reprodutivo. E acredito que a maioria discorde de que nossas principais qualidades sejam "intuição, ternura e beleza"... Vamos discutir isso?

Todos os que escreveram na sequência apoiaram as manifestações das companheiras e Eliane, a iniciadora da discussão, sugeriu explorar a polissemia do Triskle e tomar como referência outros conjuntos de significados, mais alinhados com os ideais da Raiz. E assim os simbolismos mobilizados foram:

1. Simbologia ligada ao constante movimento de ir, representando: a ação, o progresso, a evolução, a criação e os ciclos de crescimento.

2. Simbologia ligada às representações da triplicidade: Corpo, Mente e Espírito; Passado, Presente e Futuro; Céu, Terra e Mar; Primavera, Verão e Inverno... os ciclos de transformação. Este símbolo está, ainda, associado ao crescimento pessoal, ao desenvolvimento humano, ao fluir e à expansão da consciência física e espiritual. A cor marrom do símbolo representa a terra. (MANUAL DA IDENTIDADE VISUAL - RAIZ: 5)

A transformação e o crescimento eram continuamente apontados como objetivos e como preocupações da Raiz e a referência a esses significados não me parece fortuita. Mas se a transformação precisava ser contínua, pois dela dependia a dinâmica de funcionamento do coletivo, e se o crescimento era necessário para fazer frente aos grandes problemas do país, era ainda mais imprescindível que ambos fossem balizados pelos princípios da Raiz, sob o risco dos cidadanistas se deixarem corromper pelas práticas da política tradicional e transformarem o coletivo numa máquina de angariar votos e expandir o poder, como seria o caso da maioria dos partidos existentes.

Por último, é digno de nota o recurso ao simbolismo botânico (para além da imagem da raiz), que era acionado principalmente nos discursos que tinham como objeto a configuração e o funcionamento do coletivo. Nessas situações, eram por vezes estabelecidas relações de homologia entre o movimento político e o campo da botânica: os predicados atribuídos a sementes, raízes, troncos, folhas, flores e frutos também se mostravam "bons para pensar" a ecologia das práticas políticas da Raiz. Era comum estabelecerem tanto relações diretas entre elementos de ambos os 
domínios, termo a termo, quanto relações entre sistemas de relações, como no caso do totemismo classificatório examinado por Lévi-Strauss (2009). O caso mais frequente era a referência à relação entre sementes e frutos para pensar a passagem dos princípios, baseados nas três origens (ameríndia, africana e europeia), à realização da política emancipatória do movimento, o cidadanismo. As imagens botânicas faziam mais do que servir meramente para ilustrar, de forma algo poética, as instâncias e processos do movimento político: elas também eram um importante instrumento do pensamento com efeitos nada desprezíveis. Os três princípios estariam na origem da política emancipada da Raiz assim como as sementes originam os frutos no final do seu caminho natural, o que permitia traçar outros paralelos igualmente frutíferos. As sementes definem, em larga medida, como serão os frutos, mas também dependem de outros fatores para gerarem bons frutos. Como sementes selecionadas, os cidadanistas também selecionaram entre os nossos ancestrais "aquilo que de melhor se produziu em termos de pensamento, ética e filosofia" (p.13). Entretanto, pensar a partir da fisiologia vegetal pode transformar uma preocupação botânica relativamente simples em uma questão política nada trivial: quais nutrientes garantiriam a germinariam adequadamente esses princípios para o pleno desenvolvimento do movimento-partido até gerarem bons frutos políticos? Essa era uma questão que, de tempos em tempos, voltava a fazer a parte das preocupações do coletivo e que era, não raro, formulada em termos botânicos, ao menos nesse momento formativo da associação. No entanto, não é difícil perceber que, ao mobilizar termos pertencentes a um campo discursivo específico, esses termos podem modular e modificar decisivamente a forma do discurso. É o que ocorreu quando Renan questionou o funcionamento dos Grupos de Trabalho (GT's):

Vejo cada GT como um jardim, um ambiente pra que algo (comunicação, articulação política, organização, etc.) seja cultivado. Dessa forma, garantimos que o que está ali, está crescendo e se desenvolvendo aos cuidados de quem trabalha regando, podando, adubando, no entanto, se começam a germinar plantas fora desse jardim, pra quê replantá-las dentro da cerca?! Se estão brotando bem naturalmente, porque não deixá-las crescer, desenvolver e, ao seu tempo, dar os frutos?! O mais importante não é colhermos os frutos coletivamente?!

A réplica de Sidney a essa declaração de Renan deixou implícita a concordância em relação ao uso das imagens da cerca e do jardim para falar sobre a centralização (mesmo discordando da ideia de que os GT's fossem centralizadores) embora contestasse a limitação imposta pelo imaginário botânico do crescimento natural, que o concebia como intrinsecamente não coletivo, afinal de contas, na forma de Sidney ver a política, a autonomia não era necessariamente oposta ao 
coletivo, algo muitas vezes reafirmado pelos membros da Raiz. O que me parece mais interessante em tudo isso é que a oposição crescimento cultivado/crescimento natural (ou selvagem) é visivelmente tributária do dualismo metafísico natureza/cultura e de sua variante indivíduo/sociedade e o que esse caso mostra é que, quando esse dualismo se estabiliza em outro código, ele pode, em retorno, ser reforçado por ele. Assim a tentativa dos cidadanistas de ultrapassarem a oposição indivíduo/sociedade no campo de suas práticas políticas também teve de lidar com as limitações impostas pelo uso de imagens de outro campo (botânica), mas radicadas nessa mesma oposição fundante.

A seguir farei um resumo das três ideias-semente da Raiz (Bem Viver, Ubuntu e Ecossocialismo) - priorizando o conteúdo reiterado com mais frequência nas suas ações - e do Consenso Progressivo, considerado o nutriente mais importante para o seu pleno florescimento. É importante ressaltar que, embora houvesse iniciativas para aprofundamento dessas ideias (para entenderem como elas operavam em seus contextos de origem), elas eram sempre redefinidas quando traduzidas para as publicações escritas e quando eram acionadas em suas práticas e são esses significados que me parecem mais relevantes para dialogar com essa forma de fazer política.

\subsubsection{Bem Viver (Tekó Porã)}

O conceito de Bem Viver, inspirado na ideia Guarani de Tekó Porã, encontra aproximações nas cosmologias de vários povos ameríndios, como nos conceitos quéchua de Sumak Kawsai e o aymara Suma Qamaña. O Bem Viver da Raiz fundava-se na ideia de que é preciso aprender a viver com os outros existentes e reconhecer que a humanidade é parte da comunidade da vida e não pode viver "à parte da natureza" (RAIZ.CARTA CIDADANISTA:14). A tradução do pensamento ameríndio para o conceito de Bem Viver cidadanista foi feita, em grande medida, por meio do estabelecimento de uma relação de oposição quase simétrica em relação à ideia de "viver melhor", atribuída ao capitalismo e ligada ao produtivismo/consumismo desenfreados e à exploração predatória da natureza e do homem pelo homem. Embora o manifesto reconheça a necessidade de seguir as cosmologias ameríndias, "fundindo cultura e natureza" (p.15), ainda nele subsistem elementos que só podem ser entendidos no âmbito desse dualismo e de outros elementos fundadores da nossa metafísica. A ideia de que os povos tradicionais nos ensinam que a terra é acolhedora e que deve ser protegida está mais para uma lição dos povos que aprenderam antes os ensinamentos 
da metafísica cristã (seja diretamente, pela da igreja, seja indiretamente, por meio dos seus representantes mais mundanos, como o ativismo ecológico e algumas vertentes do socialismo) do que, propriamente, de um pensamento que remeteria à origem desses povos, como supõe a Carta. ${ }^{9} \mathrm{O}$ mesmo pode ser dito em relação às referências à Pachamama (p.16), divindade que, em um passado distante, não apresentava os atributos que hoje consideramos maternais, como geralmente meus interlocutores supunham em algumas referências à divindade (DANOWSKI; VIVEIROS DE CASTRO 2014:146). O que não quer dizer que os povos indígenas não acionem esses atributos ao se referirem à Pachamama, pelo contrário. A questão é que esse uso dificilmente poderia ser remetido a uma ancestralidade pré-colombiana como comumente se faz e tudo leva a crer, embora isso ainda cause muito desconforto, que Pachamama sofreu uma espécie de domesticação por meio de sua associação à imagem da Virgem Maria (Galinier \& Molinié 2006).

O conceito de Bem Viver foi, dentre as ideias-semente, a mais acionada na campanha eleitoral e não é difícil entender o porquê. Ao conversar com eleitores nas atividades de campanha, vi que era muito frequente a associação do Bem Viver com ideias relacionadas à natureza, reciclagem, diminuição da poluição e até com a priorização do transporte público e direito à cidade - o que não deixa de ter relação com os significados acionados pelo próprio coletivo -, sendo que a maioria desses interlocutores não fazia ideia de sua origem ameríndia. O padrão gráfico do material de campanha também parece ter contribuído para ressaltar esses significados relacionados à natureza.

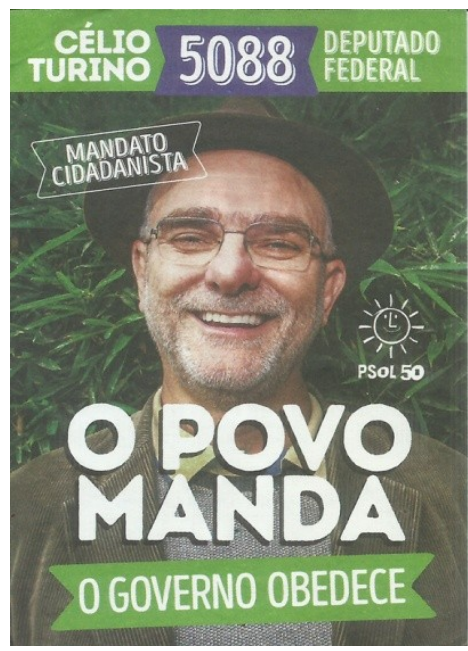

Fig.3. Esse foi um dos santinhos principais da campanha do Mandato Cidadanista, tendo o Célio Turino como cabeça de chapa. Há uma clara alusão a elementos ecológicos, embora nenhuma referência direta ao Bem Viver.

9 Também não podemos desconsiderar a importância estratégica do discurso da proteção ambiental para a própria sobrevivência de muitas populações indígenas. 


\subsubsection{Ubuntu}

Noção originária de povos de língua Bantu e que foi sistematizada em uma ética muito difundida na áfrica subsaariana, estando na base da política de reconciliação na África do Sul pósapartheid. Pode ser expressa na frase de um dos seus maiores difusores e sistematizadores, o arcebispo anglicano Desmond Tutu: "sou o que sou graças ao que somos todos nós" (DESMOND TUTU 2007:28). Ubuntu remete à noção de interdependência, compreensão, colaboração. Os membros da Raiz elegeram a filosofia Ubuntu como objeto de estudo e como uma de suas raízes, pois ela representaria uma ruptura com a lógica do individualismo exacerbado ocidental. A ideia de Ubuntu era sempre acionada durante as interações, tanto nas reuniões presenciais, como nas conversas em meio digital. Na maioria das vezes ela funcionava como um parâmetro para caracterizar e avaliar as atitudes dos membros do coletivo. Um trecho de um debate acirrado em um tópico sobre a construção colaborativa da Carta Cidadanista, ilustra bem o modo como o termo costumava aparecer nas conversas:

Mania de ao invés de se ater ao que se coloca enquanto pensamentos e argumentos, partir para o ataque às pessoas, colocando-se no lugar de "narrador das atitudes alheias" ("...quero registrar..."). Que fique isto registrado também, atitude muito pouco Ubuntu.

Diante das discordâncias e desavenças que barravam o avanço na escrita da Carta, mais uma vez o Ubuntu é reivindicado:

Peço um pouco de generosidade, desprendimento e capacidade de colaboração, um pouco de UBUNTU, enfim, para que, ao menos desta vez, se consiga dar um passo adiante.

É importante aqui atentar para uma questão fundamental: as definições dos conceitos da Raiz não foram estabelecidas de forma exaustiva e sistemática (embora tenham sido apresentadas no manifesto fundador), mas se davam, sobretudo, nas situações em que eles eram acionados e, por isso, se mostravam permeáveis à contingência e à transformação. A análise situacional dos conceitos em uso mostra como os atributos, os termos e as práticas a eles associados são 
indispensáveis para a compreensão dessas dinâmicas de significação. Contudo, é preciso reconhecer que de tempos em tempos ressurgiam reivindicações de maior embasamento e consistência teórica para a manutenção desse conceitual no repertório coletivo. É razoável supor que a adoção desses conceitos não se deu somente em razão da constatação (racional) de afinidade entre modos de pensar. Fica bastante claro, sobretudo no caso do Ubuntu, que o processo de constituição desse conceitual também comportava certo julgamento estético e afetivo:

Terceiro, nós precisamos assumir nossas raízes africanas, assim como ameríndias, e a melhor forma de fazê-lo é assimilando, jogando luzes naquilo que de mais virtuoso foi produzido por cada povo, e UBUNTU é tão lindo, poético, tão nobre.

Para além do esmero com a forma da Carta Cidadanista - o que é esperado para um manifesto do gênero -, era bastante notável a preocupação com a beleza dos conceitos, das ideias e das ações. Durante a escolha do nome para o partido, um dos argumentos para adoção do nome Nós, foi justamente a sua poética bastante significativa - virtude depois também reconhecida no vocábulo raiz . A avaliação das falas nas reuniões e nas atividades de campanha também era feita em termos de beleza discursiva, mais do que pela eficiência em comunicar o programa político ou pela habilidade persuasiva. Esse senso do belo que acompanhava essas ações não pode ser separado das emoções que ele despertava que podiam, tanto serem expressamente formuladas, em comentários a posteriori, como permanecerem em seus estados não-formulados, reduzindo-se, no mais das vezes, a expressões corpóreo-faciais que sugeriam assentimento e aprovação. O material de campanha também era frequentemente objeto de apreciação estética, sendo muito comum o elogio espontâneo (não estimulado) dos folhetos, panfletos e santinhos. Em uma das atividades de campanha, um interlocutor fez um comentário genérico exaltando a beleza do material, enquanto olhava para um folheto com a proposta da chapa em favor do direito dos animais. Diante da minha pergunta (com certo tom desafiador) sobre o que havia de bonito naquele material que o diferenciava de tantos outros, ele me disse:

- Esse material tem personalidade, tem a cara da Raiz.

- Como assim, cara da Raiz? - perguntei.

- Ele tem cor, é bonito, é simples, mas chama a atenção, não parece material político.

- É, não tem nada a ver com o material dos tucanos, nem com do PT... Esse boi é simples, mas tem uma coisa lúdica que desperta a curiosidade [falei levantando o panfleto e olhando-o fixamente] 
- Isso aqui é afeto, é arte, quem vê não passa batido, sente vontade de pegar.

O que muitas vezes esses agentes sugeriam é que a política pode ser, mais do que um método frio de governo e tomada de decisão, uma forma coletiva de encantamento da vida, mais do que a arte de governar, pode ser um governo com a arte, uma 'poética política'. Não é difícil entender como se constituiu essa visão quando consideramos que o coletivo era composto por jovens católicos, artistas, professores, socialistas libertários, ecologistas e ativistas de várias causas que se empenhavam em resistir e criar, sobre as ruínas de mundos arrasados, mundos que fossem, não apenas habitáveis, mas animados pela vida, pela arte e pela poesia. Na primeira reunião após o resultado final das presidenciais, os participantes foram chegando ao local do encontro e se acomodando em silêncio, com expressões de profundo desânimo e tristeza por conta do resultado. Fui um dos primeiros a chegar e me sentei à mesa, para aguardar os demais. Era notável o silêncio dos presentes, dispostos em intimidade sem, contudo, proferirem nenhuma palavra, até que William começou a circular algumas folhas avulsas contendo alguns poemas de sua autoria, alguns dos quais versando justamente sobre política. De repente, o silêncio foi quebrado e um dos presentes começou a falar sobre os poemas, outro sobre literatura e o terceiro sobre como a arte é capaz de nos tirar do imobilismo e nos munir de forças para seguir adiante e sonhar. Não é à toa que a cultura (ao lado da educação) entrava sempre em cena quando estavam em discussão os programas políticos do coletivo ou os requisitos para uma cidadania emancipada.

\subsubsection{Ecossocialismo}

O Ecossocialismo é uma corrente de pensamento político que se formou a partir da convergência de elementos do socialismo libertário, do marxismo e dos movimentos ecológicos. Acompanha o marxismo na crítica ao modo de produção capitalista, mas dele se afasta por sua suposta insistência no produtivismo desenfreado e predatório ${ }^{10}$. Para a Raiz, o reformismo, em suas versões capitalismo sustentável ou capitalismo verde, tenderia a manter intacta a essência destrutiva do capitalismo e seria, portanto, preciso romper com esse sistema. Não se trataria, contudo, de uma ruptura abrupta, ideia-guia dos movimentos revolucionários do século passado, mas de uma espécie

10 Como não poderia deixar de ser, essa visão de um socialismo marxista ambientalmente predatório não é compartilhada por muitos socialistas e ecossocialistas. Há, inclusive, autores como Gasper (2014) que defendem que Marx foi um precursor das preocupações ecológicas. 
de reformismo para fora do sistema, ou seja, por meio da promoção de lógicas que subvertam aquelas que sustentam o sistema vigente. Na Raiz, era muito forte o sentimento de que a catástrofe ecológica já estaria acontecendo e que essa crise só poderia ser remediada (talvez revertida) com ações urgentes que deveriam começar na esfera da vida cotidiana, mas requereriam, mais do que nunca, o protagonismo dos governos, daí a necessidade imediata de atuação também nos meios políticos institucionais, para além do ativismo ecológico tradicional. Havia, na prática, certa tolerância ao ideário desenvolvimentista (defendido por uma parte da esquerda brasileira), sobretudo por ele vir acompanhado da defesa da redução da desigualdade via políticas de distribuição de renda e da defesa de direitos sociais. Entretanto, esse era um ponto de controvérsia e persistia a ideia de que não seria possível conciliar um projeto nacional desenvolvimentista, nos moldes defendidos por essa fatia da esquerda (a partir de forte industrialização) e a defesa socioambiental. O manifesto cidadanista e as discussões coletivas mostravam grande afinidade com a ideia de decrescimento - que surgiu na década de 1970 e ganhou força nos últimos vinte anos -, que contesta a relação comumente aceita entre melhoria do nível de vida e crescimento constante do Produto Interno Bruto (LATOUCHE 2009). Os decrescimentistas se apoiam em modelos ecológicos e matemáticos para mostrar que o crescimento infinito não é sustentável para manutenção da vida no planeta. As reuniões da Raiz tendiam a promover ideias que iam ao encontro das bandeiras dos ecossocialistas, como a crítica ao produtivismo e ao consumismo, a defesa do fim dos mega-projetos de geração de energia e exploração mineral, a promoção de iniciativas autossustentáveis, o apoio e fomento às cadeias produtivas locais, a priorização do transporte público em detrimento do transporte individual, entre outros. O que percebi durante meu trabalho de campo foi uma preocupação crescente do coletivo para incorporar as práticas ambientalmente sustentáveis nas ações cotidianas, o que ficava claro quando discutiam possíveis ações futuras de intervenção e a própria organização das reuniões, como no caso do uso de copos plásticos descartáveis, que, até o final do meu campo ainda persistia, embora fosse uma prática que gerasse grande descontentamento e que, por isso, parecia estar em vias de ser abandonada. O Ecossocialismo da Raiz propunha uma relação de profunda sinergia com os valores solidários do Ubuntu africano e o Bem Viver ameríndio, contribuindo para uma ampliação do sentido do comum, que passava a incluir na política (e na democracia) as múltiplas formas de existência humanas e não-humanas. 


\subsubsection{Cidadanismo}

O Cidadanismo sempre foi um conceito central na proposta política da Raiz, fazendo, inclusive, parte do nome do coletivo. O termo propõe o resgate e a reinvenção do conceito de cidadania e remete à constatação de que a cidadania clássica (com origem na antiguidade e resgatada no pensamento político liberal ocidental) sempre foi excludente e de que suas promessas emancipatórias pouco se efetivaram de fato e têm como seus principais obstáculos contemporâneos o capitalismo e a desigualdade social que lhe é inerente. O Cidadanismo consiste na "ação da cidadania, buscando a efetividade de direitos" e a remoção dos obstáculos que impedem a sua realização plena, como o abuso do poder econômico e midiático e a pobreza extrema (RAIZ. CARTA CIDADANISTA 2015:33-34). Sua proposta é a reinvenção da política por meio do resgate do espaço público e das ações cooperativas e solidárias, o que requer uma abertura para as novas formas de participação e autogestão que têm sido experimentadas nas mobilizações dos últimos anos. Isso passaria pela politização das múltiplas esferas da vida e pelo empoderamento dos cidadãos, transformação que só se efetivaria por meio da educação (uma educação não instrumental, que estimule as pessoas a refletirem sobre suas realidades) e da cultura. Assim como a cidadania, o Cidadanismo supõe, além de direitos, deveres, e na base deles está o respeito às diferenças, incluindo outras formas de vida e de existência. Desta forma, o Cidadanismo acabou por englobar outros conceitos centrais da Raiz, como o Bem Viver, o Ubuntu e o Ecossocialismo. A extensão da noção de direitos aos animais e ao planeta Terra, bandeira de luta da Raiz, adquiria, portanto, sentido pleno dentro desse conceito.

O Cidadanismo era um conceito frequentemente mobilizado nas ações da Raiz e, ao que parece, de grande potencial retórico, tendo sido acionado até mesmo por um candidato aliado em uma atividade de campanha (e que não era filiado, nem participava das atividades da Raiz), quando falava aos eleitores sobre a necessidade de mandatos participativos, coletivos, comunitários $e$ cidadanistas. Nas atividades de campanha o conceito era, muitas vezes, acionado no sentido de um reavivamento da cidadania, principalmente no que diz respeito à noção de direitos. Em algumas ocasiões também era acionado para se referir ao sujeito politicamente atuante, seja no ativismo ou no meio político institucional, seja em ações cotidianas, ligadas aos problemas da comunidade. 


\subsubsection{Consenso Progressivo}

O Consenso Progressivo ocupava um lugar central nas práticas de tomada de decisão da Raiz e, por ter ocupado um espaço reduzido na Carta Cidadanista, recebeu uma elaboração um pouco mais rigorosa em formato de guia. No entanto, o documento foi apresentado como uma sugestão, como o primeiro passo para o estabelecimento de uma metodologia e, por isso, estaria aberto a contribuições e reformulações. Como veremos mais à frente, essa abertura ao exterior é também um princípio fundamental do dinamismo característico do funcionamento da Raiz. Partindo do sentido etimológico de consenso (do latim cōnsēnsus) como conformidade e concordância, os cidadanistas propunham ir além e resgatar seu sentido mais antigo, derivado do étimo cōnsentiō, que significa "sentir junto" (RAIZ. GUIA PARA CONSENSO PROGRESSIVO 2015:1). A prática do consenso na Raiz deveria buscar a efetivação da ideia de construção conjunta, uma construção que rechaça a lógica de disputa entre posicionamentos concorrentes, e parte do pressuposto de que o processo decisório exige cautela, na medida em que está inextricavelmente ligado à circulação dos afetos. Na verdade, a composição afetiva era tão importante nesses encontros quanto a pura e simples tomada de decisão. Era através dela que também se construíam laços de confiança e reciprocidade e que se constituíam o sentimento (e as modalidades) de ligação entre os sujeitos e entre eles e os temas de escrutínio político.

O Consenso Progressivo não é a constituição da unanimidade, mas a ideia de que as decisões devem ser tomadas buscando a convergência e, tanto quanto possível, o consenso. O desafio está em construir acordos sem a imposição da vontade da maioria e o esmagamento da divergência. $\mathrm{O}$ processo que leva a uma decisão final deve ser avaliado não apenas pela sua contribuição para resolução de um problema, mas também pela sua capacidade de manter e reforçar o sentimento de união coletiva e de afastar qualquer tendência ao "faccionalismo" (p.2). Assim, uma ideia que, a princípio, possa parecer a mais acertada de um ponto de vista tradicional de cálculo político (como o aumento da capacidade de expandir o campo de influência ou as alianças) pode não ser a melhor quando se tem como objetivo prioritário reforçar o sentimento de pertencimento coletivo. Para viabilizar essa proposta, a Raiz entendia que era preciso adotar e criar técnicas para a apreciação de ideias e argumentos e tomada de decisão; tais técnicas deveriam funcionar de modo a enfatizar as convergências e explicitar as divergências (ao invés de escondê-las ou ignorá-las) para que fossem negociadas. Muitas vezes se percebia que as divergências não eram insolúveis e se deviam principalmente a incompreensões de partes do que era proposto que, por esse método, poderiam ser 
esclarecidas; ou a discordâncias em relação a aspectos secundários (vistos como pouco relevantes) da matéria em discussão que poderiam ser facilmente alterados ou negociados (a discordância aqui pode muitas vezes contribuir para o refinamento da proposta). Quando as divergências se mostravam insolúveis, depois de esgotados todos os meios de negociação, partia-se para a votação. Na prática as votações deslocavam o sentido comum de voto vencedor/voto vencido em que a ideia preterida era vista como sem importância ou mesmo destituída de coerência, racionalidade, inteligência etc. Nas reuniões presenciais da Raiz, o momento da votação não era sublinhado enquanto tal, sendo muitas vezes evitado ou disfarçado, resumindo-se, no mais das vezes, ao anúncio de que, na fase de discussão, as opiniões convergiram em certo sentido e formaram maioria para uma dada decisão. Em relação às ideias que eventualmente não eram adotadas, elas dificilmente eram descartadas como absurdas, pelo contrário, sua exclusão passaria por um cuidadoso processo de justificação podendo, não raro, integrar um repertório informal de ideias que, em outra ocasião, poderiam ser resgatadas como propostas factíveis.

O coletivo admitia que, para ser efetivo, esse sistema de busca pelo consenso dependeria do real comprometimento dos participantes, condição que era frequentemente reiterada nas reuniões. Por sua vez, o comprometimento dependeria de uma atitude de desprendimento (desapego de pequenas convicções pessoais) e confiança (de que o outro "dará sempre o seu melhor") (p.3), o que os cidadanistas reconheciam não ser algo simples pois exigiria um esforço contínuo para superar formas de subjetividade muito arraigadas que promoveriam o ensimesmamento individualista. Nos encontros era muito presente a ideia de que precisavam aprender a escutar o outro, o que seria muito diferente de ouvir, ato passivo. Segundo essa concepção, escutar requer uma "interpretação ativa, profunda e generosa" (p.3) na medida em que o outro deve ter boas razões para expressar e defender o seu ponto de vista e é imprescindível tentar entendê-lo. Existiam, inclusive, reuniões especiais com o foco na escuta ativa e interessada (Escuta Profunda), sem interrupção ou contraposição de argumentos, como veremos no capítulo 3. Só depois dessa etapa de escuta compreensiva era aconselhada a manifestação do posicionamento contrário, se fosse o caso, e essa intervenção deveria ser feita, idealmente, com clareza e sempre com tom amigável, de gentileza, o que tinha o efeito claro de aproximar os presentes e de desarmar afetos que pudessem desencadear reações de hostilidade. A adesão a essas recomendações ficava clara nos momentos em que as discussões eram tomadas por discursos inflamados, mesmo agressivos, até que o emissor interrompia a sua fala com a observação de que sua raiva era direcionada ao objeto da discussão, 
não ao autor do argumento - às vezes essa tensão era, inclusive, desfeita por meio do recurso ao humor.

Em última instância todos os participantes das reuniões deveriam reunir esforços para a melhor condução das conversas, mas era esperado que alguns participantes se voluntariassem para exercer esse papel mais ativamente, eram os jardineiros. Caberia aos jardineiros intervir para a retirada de assuntos e questões que desviassem os participantes do tema em discussão. Também deveriam organizar a sequência das falas e fazer algum controle da sua duração, sistematizando no final os argumentos e ponderações e encaminhando o debate para a tomada de decisão. Vale dizer que, na prática, não havia uma diferenciação estrita entre jardineiros e não jardineiros, já que muitos contribuíam naturalmente para a jardinagem e, além disso, o termo em si era raramente utilizado nas reuniões, restringindo-se ao Guia e algumas produções escritas. Os dispositivos digitais também exerciam influência decisiva na forma como o Consenso Progressivo era definido e realizado na prática, algo que será discutido com mais vagar no próximo capítulo.

\subsection{O partido-movimento}

O modo de organização da Raiz foi inspirado na ideia de partido-movimento. O termo foi utilizado pela primeira vez por Herbert Kitschelt (2003) para se referir aos partidos formados a partir da institucionalização de movimentos sociais (temáticos ou identitários), como foi o caso dos Verdes, na Alemanha, e que mantinham, paralelamente, ações políticas como movimentos sociais e como organizações político-partidárias. Não houve, entretanto, grande transformação no modo de configuração e funcionamento desses partidos em relação aos partidos tradicionais e suas agendas políticas se mantiveram centradas nas causas específicas que lhes deram origem. O conceito de partido-movimento adotado pela Raiz tem sua origem na análise de Boaventura de Souza (2014) das formas partidárias que surgiram a partir das manifestações pós-2008 e que foi prontamente assimilado por alguns articuladores da formação que, segundo Boaventura, seria o exemplo paradigmático dessa redefinição, o Podemos espanhol. O termo não foi resultado de elaboração conceitual sistemática e tem servido para se referir às novas experiências partidárias que mantêm muitas das características dos movimentos que lhes deram origem como: democracia direta, mecanismos de transparência e horizontalidade etc. Trata-se, então, de uma instituição que opera no 
sistema político partidário tradicional, mas combina em seu funcionamento mecanismos de "complementaridade entre democracia participativa e democracia representativa" (SANTOS 2014).

A Raiz fez do fato do conceito não ter recebido uma definição fechada uma virtude, de maneira que assim ele pudesse ser definido pela prática coletiva. A ideia geral que inspirava a proposta da Raiz é a de que ela não deveria ser um partido que abrigaria ou buscaria filiar movimentos sociais (o que poderia levar à cooptação, para alguns), nem um movimento social que se organizaria em torno de causas específicas. A proposta era construir um partido (que, portanto, participasse de eleições) que fosse permeável aos movimentos sociais, que atuasse conjuntamente com eles e que estivesse em sua retaguarda. O desafio era criar um modelo organizativo que atendesse a essa proposta sem abrir mão das instâncias partidárias de caráter mais rígido, requeridas pela legislação. Para dar conta da complexidade dessa estrutura, foram criados núcleos de atuação, os chamados Círculos, que eram uma espécie de dispositivo de abertura para os movimentos sociais ou quaisquer interessados. Os Círculos deveriam ser formados por, no mínimo, três filiados e poderiam ser territoriais (localidade, bairro, cidade, etc.), temáticos (como economia solidária, educação) ou identitários (LGBT, feminista, juventude etc.). Essa abertura se completaria pela regra que concedia aos colaboradores externos (não filiados) o pleno direito de participar, inclusive das votações (presenciais ou no espaço deliberativo digital). Os Círculos foram inspirados nas instâncias de mesmo nome criadas pelo Podemos, na Espanha, e que também tinham como objetivo promover a participação da base (incluindo também interessados não filiados) na construção das ações e do programa político do partido.

Em contraposição à fluidez e abertura dos Círculos, a Esfera seria uma instância que remeteria à estrutura partidária clássica de caráter mais rígido, dando estabilidade ao movimento dos Círculos e promovendo a articulação entre fluxo e estrutura. As Esferas deveriam existir nos três níveis da federação e seriam os órgãos executivos que: colocariam em prática as decisões das Teias; zelariam pelo cumprimento do estatuto da Raiz e das exigências da legislação eleitoral e partidária; elaborariam os planos de gestão orçamentária e financeira, entre outros (RAIZ.ESTATUTO 2016: 34). Seriam compostas por Coordenações (como a Coordenação de Finanças) e Vogais (membros da executiva sem função definida).

Teoricamente, a única instância deliberativa e de direção política da Raiz seria a Teia, que também acompanharia os três níveis da federação. Caberia a ela eleger a coordenação da respectiva Esfera e outras comissões executivas. Ao contrário das instâncias de deliberação da maioria dos partidos, a Teia não teria delegados, o voto seria exercido diretamente por todos os filiados. O voto 
direto era um componente fundamental do sentido de horizontalidade da Raiz e cumpria papel decisivo para evitar o fechamento dos Círculos e, consequentemente, para impedir sua transformação em correntes que competiriam entre si para o controle da direção do partido, pois diminuiria consideravelmente a proeminência de pessoas (como seriam os delegados) e traria muito mais agilidade ao processo, uma vez que a Teia podia ser realizada, tanto presencialmente (Teia Plenária e Teia Convenção), como em meio digital (Teia Digital). As propostas amadurecidas e aprovadas no âmbito de um Círculo poderiam ser encaminhadas para votação na Teia após serem remetidas ao Grupo de Trabalho (GT) que teria maior afinidade com as suas temáticas, se houvesse. Os Grupos de Trabalho eram grupos especializados dedicados à criação e à implementação de propostas que surgiam em qualquer instância da Raiz, mas caíram em certo descrédito e foram paulatinamente sendo desativados, em parte por razões que serão apresentadas no capítulo 2. Essa arquitetura tinha por objetivo assegurar um arranjo que permitiria a atividade político-partidária e que, ao mesmo tempo, garantiria que os Círculos fossem autônomos e funcionassem em contínua relação de troca e de fluxo com os movimentos, com independência operacional e deliberativa (para os seus objetos de atuação) e sem estarem subordinados às Esferas.

\subsection{O partido em movimento}

Nos primeiros anos da Raiz, o contato inicial com o coletivo era estabelecido, principalmente, por meio da rede social Facebook. Uma concepção comum no movimento era a de que essa plataforma seria um instrumento perverso do capitalismo de controle e de que sua estrutura dificultaria muito o diálogo (o que ficará mais claro no próximo capítulo). Ainda assim, o reconhecimento geral era de que a rede social tinha sido decisiva para reunir os membros fundadores a partir do grupo digital do movimento Avante e foi imprescindível para a comunicação e ampliação da base social da Raiz. Eu tomei ciência da existência do coletivo Avante na imprensa online e estabeleci contato após ter encontrado o Avante na rede social. Muitos dos que passaram pela Raiz entraram no coletivo através do Facebook. E foi também por meio dessa plataforma que alguns cidadanistas ingressaram nos Círculos, os segmentos que constituíam a base de atuação na Raiz. Durante um bom tempo foi principalmente no Facebook que se realizava o princípio de abertura ao exterior, uma ideia que se encontrava no âmago da concepção dos Círculos. Essa permeabilidade dos Círculos garantia que o funcionamento do partido-movimento fosse alimentado 
pela dinâmica móvel dos coletivos ativistas e do engajamento dos colaboradores. Em um tópico de discussão no Loomio, plataforma digital do movimento naquele momento, Rafael, um dos membros-fundadores da Raiz, anuncia sua saída dizendo que esperava ter deixado algumas sementes. De fato, a entrada e a saída contínua de pessoas no coletivo, propiciadas pela autonomia e abertura dos círculos, foi decisiva para munir o movimento de ideias e para abri-lo ao inesperado e à contingência. Um bom exemplo foi o processo de constituição da associação como partido que teve a participação ativa de pessoas identificadas com o socialismo libertário de inspiração anarquista. Mesmo que algumas dessas pessoas tivessem se desligado do coletivo antes da sua formalização, sua participação nos debates de formação do coletivo contribuiu para deixar nos documentos e diretrizes do movimento um forte teor anticapitalista. O mesmo se pode dizer a respeito da abertura para a participação de mulheres e minorias sociais. Ainda que um debate sobre uma questão que dissesse respeito à causa $L G B T$ pudesse ser iniciado por um hetero, logo ele seria lembrado que deveria acionar o Círculo correspondente para continuar a discussão. Idealmente, nenhuma decisão que envolvesse minorias seria tomada sem a plena participação e deliberação de representantes dessas minorias. Isso permitia uma troca e um aprendizado bastante fecundo entre os membros da Raiz, abrindo o coletivo para pensar outras possibilidades de ser e estar no mundo, como na construção colaborativa do estatuto na qual alguns dos participantes nunca tinham pensado na possibilidade da existência de identidades de gênero não-binárias, um debate, portanto, com efeitos na própria constituição do mundo.

Como vimos anteriormente, ao contrário da fluidez e flexibilidade (e permeabilidade) dos Círculos, as Esferas eram fixas e rigidamente regulamentadas, com divisões territoriais bem estabelecidas. Embora, de certo modo, possamos remeter a distinção Círculos/Esferas à oposição fluxo/estrutura, é preciso tomar cuidado para não reduzi-las a um binarismo estático. Nos dois casos parecia haver processos atuando em sentido inverso, quais sejam, o da cristalização dos Círculos e o da flexibilização das Esferas. Com o passar do tempo houve uma tendência ao autofechamento de alguns Círculos, sobretudo, quando formados por especialistas em um determinado assunto. Por seu turno, as Esferas receberam, até certo ponto, um afluxo de ideias e pessoas oriundas dos Círculos (seu próprio corpo constitutivo poderia ter atuação nos Círculos), além de ter uma rotatividade considerável em seu quadro que se contrapunha a uma tendência inerente às Esferas em direção à cristalização de hierarquias e procedimentos. 
Foram os africanistas da escola de Manchester que fixaram na Antropologia a noção de segmentaridade. Essa noção atendia à preocupação de entender como sociedades sem um aparelho estatal centralizado poderiam subsistir e funcionar. Tendo como base esses estudos, a Antropologia, durante muito tempo, tendeu a opor formas sociais segmentares e formas sociais estatais centralizadas. O que essa forma de fazer política nos mostra é que, não só os modelos segmentares podem estar em operação nas organizações estatais (no caso, no sistema partidário), mas que eles podem atuar em articulação com modelos segmentares não-estatais. No lugar da oposição segmentário e centralizado, o que o modelo em questão sugere é uma aproximação com a distinção deleuziana entre segmentaridade flexível e segmentaridade dura (DELEUZE; GUATTARI 2012). A organização territorial das Esferas (municipal, estadual, federal) talvez seja o exemplo mais próximo da ideia de segmentaridade dura, na qual os segmentos territoriais, mesmo estando dispostos concentricamente em níveis diferentes, operavam sempre segundo um centro organizador, "um centro de significância" (p.113), que ressoava no âmbito de cada nível. Por outro lado, na segmentaridade flexível dos Círculos não havia um espaço político homogêneo para sobrecodificálos; esses segmentos tinham sua "própria medida interna", faziam e se desfaziam, absorviam e eram absorvidos, se fundiam e se transformavam em outros, sempre uns com relação aos outros, como na transformação (por meio de fusão) do círculo temático Ecossocialista no círculo Ecossocialismo e Liberdade. Essas noções tornam bastante significativa a diferença entre a segmentaridade das Esferas (que eram, por sua natureza, territoriais) e a dos Círculos territoriais. Embora o Círculo da cidade de São Paulo (Sampa) também tivesse uma referência territorial, ele era atravessado por dinâmicas que não operavam por referência a um centro irradiador (como era o caso da Esfera São Paulo). É preciso, no entanto, ter cautela e não tomar essa dualidade a partir da ideia de opostos estanques e o que o campo propôs foi justamente pensá-la como processos que se embaralham e se constituem mutuamente. Tudo leva a crer que as coisas se passavam de maneira muito mais complicada e esse arranjo político era atravessado por movimentos múltiplos, por vezes contraditórios, sobretudo movimentos que atuavam no sentido da flexibilização e mobilidade e tendências que operavam no sentido da cristalização de formas e coagulações de hierarquias.

Questões relativas à hierarquia (verticalidade) e horizontalidade eram onipresentes na Raiz; os discursos e práticas eram muitas vezes planejados, modulados, transformados e avaliados de acordo com seu potencial para promover modos horizontais de relação e para esconjurar tendências hierárquicas. Era amplamente difundida a ideia de que formas verticais de organização e relação comportam intrinsecamente um conteúdo maléfico, destrutivo, muitas vezes fruto de má intenção, 
uma espécie de demônio que é preciso exorcizar. Essa visão explica a persistente desconfiança com o caráter partidário da associação e o intenso debate inicial sobre a pertinência da proposta de institucionalização como partido. A desconfiança, aliás, exerceu um papel fundamental em inúmeras ações do coletivo e, muitas vezes, possuía uma potência supressória e moduladora que não pode ser subestimada. Geralmente a desconfiança era acompanhada de justificativas ligadas às memórias e experiências de vida pessoais (o mais das vezes, desilusões com experiências políticas anteriores) ou memórias relacionadas a uma dimensão histórica e política mais abrangente (de erros cometidos por Lenin na União Soviética aos impasses atuais do partido Podemos na Espanha). A desconfiança levava muitas vezes a situações que dificultavam e bloqueavam o diálogo, remetendo ao que um dos meus interlocutores, Pedro, chamou de horizontalismo paranoico, isto é, a percepção e a denúncia reiterada de que havia sempre alguém disposto a se apropriar do processo político, atitude que, sem dúvida, tinha como premissa a imagem do indivíduo autônomo, racional-calculista e autointeressado. Pedro chamou a atenção para os riscos dessa obsessão (fetiche) com a horizontalidade:

Uma lógica que não aparece como saudável azeitamento do processo democrático, mas como acusação paranoica de que existe uma impureza de fins, uma corrupção da assembleia sempre à espreita. Ao combater essa sombra que parece vir de todos os lados, a horizontalidade acaba devorando o próprio rabo, ao entrar num processo de vigilância constante.

$\mathrm{Na}$ prática, a horizontalidade adquiria o sentido de igualdade nas possibilidades de participação e na condução e definição do processo decisório (o que estaria na essência de uma democracia verdadeira), além de estar fortemente associada com o voluntarismo e a descentralização, aproximação que, não raro, tinha implicações bastante perigosas. A dificuldade dos colaboradores-voluntários em assumir compromissos com relação a normas e procedimentos e a descentralização das atividades dos Grupos de Trabalho (GT's) tinha, em alguns casos, levado ao atropelamento de decisões deliberadas em assembleias e a um certo fechamento hierárquico, sobretudo quando os GT's eram formados por especialistas. Foi o que ocorreu com a Comissão de Comunicação (que mais tarde se tornou um GT e depois se dissolveu deixando suas prerrogativas para a já existente Coordenadoria de Comunicação) que passou a tomar decisões, a produzir documentos (manuais) e veicular campanhas (publicando memes e textos) sem que tivessem sido debatidos e deliberados pelas instâncias deliberativas, por serem entendidas como tarefas de caráter apenas técnico. O que não deixou de gerar repetidas manifestações de indignação: 
Eu pergunto para todos: [...] que instância ou espaço decidiu pelo tal "manual de chegamento", que instância ou espaço decidiu pelo manual de Consenso Progressivo. Estes documentos todos estão lá no site como documentos oficiais da Raiz, mas quem decidiu sobre estes documentos foram meia dúzia de pessoa que participavam dos tais GTs (aliás não houve decisão formal!!!) [...] Se continuar criando pequenos guetos (GRs, Coordenadorias, Comissões, etc.) que funcionam como espaço de deliberação paralelo não vamos ter nem Círculos, nem Teias e nem Esferas, pois o espaço de poder e deliberação virtual vai continuar sendo acessado por meia dúzia, no máximo uma dúzia de militantes, e as deliberações continuaram sendo fragmentadas e decididas por pessoas que não tem nenhum mandato..

Nesse caso, o pressuposto da separação entre técnica e política resultou na imposição de decisões sem um debate político ampliado, remetendo aos perigos nefastos das tecnoburocracias. A partir da reflexão conjunta sobre o modo como o trabalho dos agentes de comunicação desafiava essas separações e da reflexão sobre as implicações do que antes era visto apenas como técnica, integrantes do coletivo de comunicação foram paulatinamente se convencendo de que decisões sobre quais seriam as campanhas veiculadas, quais os meios de divulgação e em que momento seriam veiculadas, eram também questões políticas e não poderiam ser monopolizadas por um grupo fechado de especialistas. A dissolução da separação entre técnica e política fez parte de um movimento coletivo em torno da redefinição e ampliação dos sentidos da política e da democracia, levando a politização das situações cotidianas mais triviais. O que os cidadanistas muitas vezes mostraram é que, ao mesmo tempo em que os significados atribuídos à política determinavam as práticas dos sujeitos, esses significados também eram transformados pelo pensar e pelo fazer coletivo, sendo, ademais, intrinsecamente abertos ao evento e à transformação.

Pensando nessa abertura, acontecimentos e eventos que, em princípio, não teriam relação alguma com a prática político-partidária adquiriram relevo. Era muito comum nos encontros a realização de práticas criativas com aspecto lúdico, tais como danças circulares e dinâmicas de grupo que, como vimos antes, frequentemente veiculavam significados que evocam um simbolismo difuso ligado à terra e ao fazer coletivo. Essas reuniões eram atravessadas por diferentes formas de solidariedade, além de gestos e ações que apontavam para a busca de outra relação com o corpo, como o ato de sentar no chão, de contato entre corpos, de dar as mãos etc. Tais ações apontam não apenas para o deslocamento dos sentidos usuais da política, mas para a tessitura de um outro eu e de um outro mundo. Não era incomum que reivindicassem o caráter experimental e criativo dessas ações e, em lugar de se pautarem na ideia de viverem como se fossem livres, buscavam, ao mesmo 
tempo, construir e vivenciar o mundo que almejavam, mas cuja imagem futura não poderia ser antecipada com exatidão. O que parece acontecer aqui é uma torção da concepção revolucionária clássica linear (emergência do mundo sonhado a partir da ruptura revolucionária com as formações sociais do passado) e da concepção reformista mais corrente (alcança-se o mundo futuro desejado por meio da soma contínua de transformações, isto é, da sua realização progressiva, ainda que possa haver vacilos e recuos). O que está em pauta parece ser a ideia de que a práxis política invoca e constrói o mundo (futuro) e nesse movimento também se transforma, em virtude de sua relação com esse mundo continuamente em mudança. O que essas práticas e muitas outras parecem colocar em xeque é a ontologia do tempo linear que alicerça os modelos modernos de transformação revolucionária e isso não me parece pouca coisa. Não somente não há ponto no futuro a ser alcançado como o futuro é profundamente marcado pela permeabilidade, abertura e indeterminação.

É importante chamar atenção para o fato de que a participação da Raiz nos protestos e ações de rua não era marcada pela adesão explícita às práticas de protesto criativo, que têm se destacado nas últimas décadas por problematizarem a linha divisória entre as expressões artísticas e a política, chamadas por alguns autores de "artivismo". ${ }^{11}$ Os cidadanistas valorizavam a simples presença nas manifestações e, na maioria das vezes, sequer planejavam um encontro prévio para irem conjuntamente aos protestos - o que ocorria eram combinações ocasionais para se encontrarem antes ou durante o ato (geralmente via aplicativo de mensagens WhatsApp). Essa ausência de preocupação com a forma dos protestos é facilmente compreensível quando vemos que se tratava de um modo de fazer política que defendia, continuamente, a não separação da política das outras esferas da vida cotidiana. Mas também não seria surpresa se, em outro momento, houvesse a incorporação de performances artísticas nos atos de protesto, uma vez que o coletivo defendia reiteradamente que a arte deveria fazer parte da política e das múltiplas esferas da vida. De todo modo, ambas as alternativas desafiam as interpretações do protesto segundo o modelo de espaço liminoide de Victor Turner (1979). Para Turner existe uma fronteira (metafórica, simbólica, espacial ou temporal) que separa o espaço liminoide do restante da vida coletiva. As duas alternativas parecem ir justamente no sentido oposto, qual seja, o de romper fronteiras que separam os espaços e onde é possível jogar com os significados que lhes são comumente atribuídos, apresentando-se como uma ameaça à ordem estabelecida (Di Giovanni 2015:21). Embora não

11 No dossiê Artivismo, publicado no Cadernos de Artes e Antropologia, Paulo Raposo (2015) define o Artivismo como "um neologismo conceptual ainda de instável consensualidade, quer no campo das ciências sociais, quer no campo das artes. Apela a ligações, tão clássicas como prolixas e polêmicas entre arte e política, e estimula os destinos potenciais da arte enquanto ato de resistência e subversão. Pode ser encontrado em intervenções sociais e políticas, produzidas por pessoas ou coletivos, através de estratégias poéticas e performativas.” 
houvesse preocupação com táticas e performances de protesto, havia geralmente referências positivas às ações orquestradas por outros manifestantes e à ocupação coletiva do espaço público e, sempre quando podiam, os membros da Raiz exibiam com orgulho suas camisetas, bandeiras ou faixas com os símbolos do movimento. O aparecer ou marcar presença nos protestos era muito valorizado, inclusive, a ideia de convocar manifestações (puxar manifestações) chegou a ser discutida em algumas reuniões.

A análise da dinâmica de alianças também parece fornecer pistas importantes para compreender esse processo de construção e abertura para o mundo. A costura (ou a recusa) de acordos e arranjos com coletivos, setores tradicionais da esquerda ou frentes de mobilização revela uma mudança paulatina de postura que ia da resistência inicial a composições com alguns coletivos tradicionais de esquerda (identificados com o centralismo burocrático e o personalismo) a uma postura mais pragmática, voltada para composições pontuais em torno de problemas específicos, a ponto de surgirem propostas que defendiam o diálogo com setores identificados até com a centrodireita político-ideológica, algo que seria pouco provável no começo da Raiz, tendo em vista o teor dos debates a esse respeito. Essa mudança de postura se baseia em parte na ideia de que seria possível avançar na construção de um novo mundo a partir de compromissos mínimos e que essas composições entre heterogêneos já seriam, por si mesmas, a realização de um novo modo de viver a política. Por outra parte, diante da grave crise que tem ameaçado direitos básicos e a existência de inúmeras formas de vida, a ideia de composição de grandes alianças (frente ampla) não apenas se tornou aceitável, mas passou a ser vista como uma necessidade cada vez mais premente.

Quando olhamos para essas composições, aproximações ou afastamentos vemos frequentemente o conceito de esquerda ser mobilizado para justificar, mapear e interpretar essas dinâmicas. Os cidadanistas geralmente viam a esquerda como um campo do espectro político razoavelmente fácil de identificar, embora multifacetado, e o mero pertencimento a esse campo já continha em si um indicativo de que alinhamentos seriam possíveis, uma vez que reconheciam nele certa sensibilidade compartilhada em relação à justiça social. Se a Raiz se opunha a várias ideias e práticas da esquerda, por um lado, por outro ela se alinhava a muitas outras, mas nem sempre esses alinhamentos eram automáticos. Nessa perspectiva, ser de esquerda significava ter uma sensibilidade acentuada para com o sofrimento dos socialmente excluídos, mas sem excluir completamente a ideia de compartilhamento de uma série de atributos e ideias, que poderiam variar consideravelmente. Assim, não é difícil constatar que ser de esquerda na Raiz não significava a mesma coisa para todos os seus integrantes e ainda que essa afirmação possa parecer um tanto 
trivial, ela tem implicações nem um pouco óbvias. O conceito de esquerda, sem dúvida, serviu para unir e para relacionar essas pessoas, como afirma a vulgata corrente. Mas o que ela não diz é que o que esse conceito unia e relacionava eram, sobretudo, diferenças. Na prática, a constatação de pertencimento ao mesmo campo político, por si só, já inclinava os agentes a boas relações, não sendo muito relevante a identificação ou vinculação específica dentro do campo. No entanto, a apresentação de pontos de vista diferentes nas ações e discussões era, não apenas estimulada, mas determinante e altamente valorizada, embora também pudesse, em certos casos, afetar negativamente as relações quando geravam discordâncias insolúveis. As virtudes da contribuição diferencial nos debates eram geralmente relembradas em termos de aprendizado, complementação, refinamento e correção e isso era facilmente percebido nas situações em que os presentes estavam falando de ações e políticas voltadas para realidades que não vivenciavam, como era o caso da discussão de políticas para as minorias. O que não significa, no entanto, que só o integrante de uma minoria social tinha voz legítima para falar sobre as questões que afetavam essa minoria, inclusive, já presenciei críticas diretas à ideia de lugar de fala por supostamente ir nessa direção (muito embora essas críticas me pareçam longe de serem consensuais). A visão era, sobretudo, de que a condição de minoria, a sua vivência diferencial, tornava seu ponto de vista um operador inestimável de abertura para outras realidades, sem, no entanto, excluir a possibilidade do diálogo franco e da interlocução com os que não fizessem parte dessa minoria. A importância conferida às falas dos que participavam pela primeira vez dos encontros (que se expressa no nível de atenção, no convite insistente às falas, na interlocução com o orador) também pode ser mais bem entendida nessa chave da contribuição diferencial do que, meramente, como uma forma de estabelecer boas relações com o visitante. Os níveis de atenção, interação e as expressões de satisfação com a fala do visitante pareciam acompanhar a magnitude das suas contribuições (argumentos, sugestões, contraposições), como se os presentes tivessem prazer em extrair o máximo de diferença do seu interlocutor. 


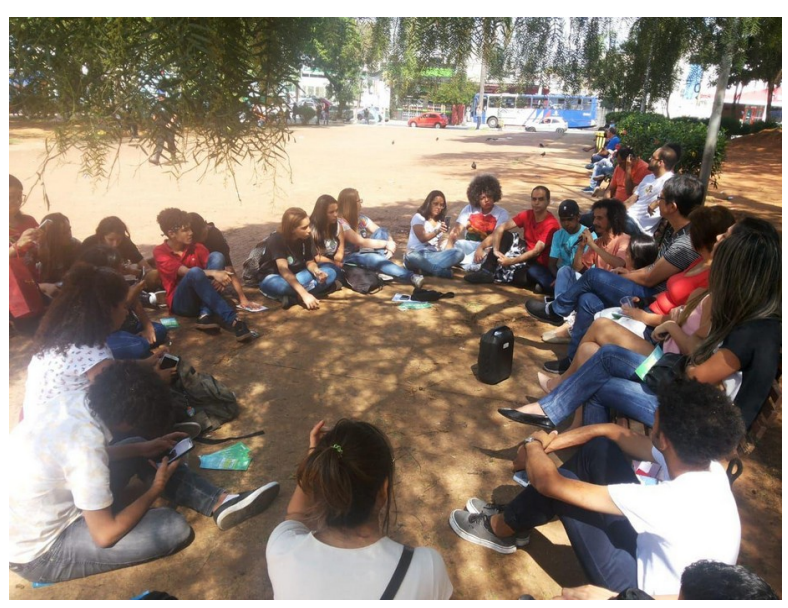

Foto 3. Roda de conversa aberta na Praça do Forró, em São Paulo, na campanha eleitoral do Mandato Cidadanista para a câmara federal, em setembro de 2018. Autoria: Mandato Cidadanista.

A abertura da Raiz à participação diferencial tinha claramente o efeito de impedir o fechamento do coletivo em pequenos segmentos autocentrados - tendência que foi constatada em alguns Grupos de Trabalho, como vimos -, e de estimular a adoção de novas ideias e práticas políticas coletivas. A concentração das atividades dos cidadanistas em dispositivos digitais, nos primeiros anos de sua formação, representou a expressão máxima desse movimento de abertura ao promover o encontro e a colaboração entre múltiplos agentes, além de contribuir para dar uma forma específica a esses encontros, tendo incidência direta nas práticas políticas do coletivo, inclusive nas suas tensões e ambivalências constitutivas. 


\section{CAPÍTULO 2. DIGITALIZANDO A POLÍTICA E (COSMO)POLITIZANDO O DIGITAL ${ }^{12}$}

Como vimos no capítulo anterior, o digital teve um peso decisivo na conformação e na dinâmica de funcionamento da Raiz e este capítulo tem como objeto central o papel e os efeitos da digitalidade no conjunto dessas práticas políticas. A maior parte do material analisado provém da plataforma digital utilizada pelo coletivo nos seus primeiros anos (2015-2017), mas foram feitas incursões mais pontuais em outras plataformas e dispositivos. ${ }^{13}$ Não é meu objetivo aqui, portanto, fazer uma análise sistemática da participação digital do coletivo com o intuito de compor um quadro detalhado, mas sim pôr em relevo dinâmicas que marcaram decisivamente o fazer político desses agentes. O próprio descentramento e experimentalismo inerentes aos modos de atuação dos cidadanistas não permitiriam perseguir tal intento, uma vez que dispositivos que eram bastante utilizados, de repente foram simplesmente descartados, do mesmo modo que grupos digitais de discussão continuamente surgiam e desapareciam, às vezes, sem sequer serem conhecidos pela maioria. Como veremos adiante, o foco deste capítulo no digital é, antes, um artifício explicativo, pois na realidade, digital e não-digital, faziam partem de uma mesma trama complexa que constituía tais modos de fazer política e que só pode ser desenredada analiticamente.

A plataforma digital da Raiz revelou-se em seus primeiros anos um espaço fulcral de discussão e deliberação e nela que eram postos em prática, cotidianamente, os princípios e as formas de fazer política defendidos pelo coletivo. Ela foi fundamental para definir o caráter e os modos de atuação do Movimento Cidadanista, de modo que a ideia, ainda muito influente nas ciências sociais, de que o ambiente virtual é apenas um recurso, uma ferramenta neutra que facilita o diálogo, a tomada de decisões e a realização de atividades conjuntas, mostrava-se bastante problemática quando contrastada com a prática efetiva desses agentes. A constatação dessa limitação na abordagem clássica do digital nos convida ir além do objetivo de compreender como as pessoas se apropriam e fazem uso dos dispositivos digitais para explorar como as lógicas da digitalidade podem transformar as nossas relações e deslocar conceitos que estão na base do pensamento social.

12 O primeiro esboço deste capítulo foi apresentado em Comunicação no $56^{\circ}$ Congreso Internacional de Americanistas, em julho de 2018, em Salamanca, Espanha.

13 A análise das práticas digitais continuará no próximo capítulo, com a plataforma WhatsApp. 
A abertura da Antropologia às potencialidades do digital pode ser entendida como consequência direta da grande transformação ocorrida recentemente nas humanidades nos estudos sobre os objetos, tendo entre as correntes mais representativas o pós-humanismo (BARAD 2007), a chamada ontologia orientada para objetos (BOGOST 2012) e o novo materialismo (BRYANT; HARMAN; SRNICEK 2011). No campo da Antropologia propriamente dito e sob a influência de algumas ideias que estão na base da chamada virada ontológica, o volume publicado em 2007, Thinking Through Things: Theorizing Artefacts Ethnographically (HENARE; HOLBRAAD; WASTELL 2007), propõe uma transformação profunda do estatuto das coisas, no sentido de nelas reconhecer formas genuínas de alteridade. Essa proposta busca distanciar-se das análises inspiradas na obra de Alfred Gell, muito influentes desde o final do século passado e que têm como uma de suas preocupações centrais identificar e explicar a agência dos objetos.

Em Art and Agency (1998), Gell defende que a agência é um atributo que também deve ser estendido aos artefatos e tais objetos seriam portadores agência em virtude da sua ligação com os humanos em uma cadeia causal (p.20-21). Gell dá como exemplo as minas enterradas no Camboja: esses artefatos explosivos seriam índices das intenções assassinas de Pol Pot e se tornariam agentes ao materializarem essas intenções. O problema dessa visão é que, em última instância, as coisas não podem realmente ser agentes, elas apenas indexam uma agência que é propriamente humana, isto é, são apenas índices das intenções de um agente humano (HOLBRAAD; PEDERSEN 2017:204205). Nesse sentido, compreender as coisas equivale a compreender a agência humana que está por trás delas, de modo que não se pode esperar que o estudo da coisa faça alguma diferença, isto é, que tenha um efeito de incidir diferencialmente nas conceitualizações antropológicas. Além disso, essa perspectiva repousa na premissa de uma distinção entre coisas e pessoas, uma divisão muito criticada por refletir os pressupostos da ontologia naturalista euro-americana.

Uma abordagem alternativa a essa visão e que possui grande prestígio dentro da Antropologia começou a ser construída a partir das ideias de Bruno Latour. Em sua Teoria AtorRede (1994;2005), Latour faz uma crítica veemente à distinção naturalista entre natureza e cultura e entre pessoas e coisas. Para ele, pessoas e coisas são híbridos e apenas aparecem como entidades particulares enquanto propriedades emergentes de uma rede na qual, em realidade, apresentam-se conectadas de várias formas e onde se constituem e se transformam mutuamente. Se a coisa-em-si não existe na visão latouriana é em virtude de ela ser, na verdade, uma associação ("assembleia", “coletivo", "nó”) e assim se torna fácil entender como qualquer interesse nas propriedades das coisas seria desprovido de sentido, dado que essas entidades isoladas não passariam de artifícios 
criados por meio da "purificação" naturalista dos modernos. O problema é que ao deixar de lado a ideia de coisas como entes portadores de propriedades específicas, torna-se difícil compreender como elas podem fazer a diferença nas assembleias das quais fazem parte, o que não impede Latour, contraditoriamente, de identificar no híbrido arma-homem as características distintivas de uma arma, como velocidade, mecânica de detonação etc. (LATOUR 1999). Ao que parece, a substituição da ontologia naturalista pela ontologia das redes latouriana ainda mantém limitações consideráveis para a análise antropológica dos objetos.

Longe de reivindicar a separação apriorística entre pessoas e coisas, o que a virada ontológica propõe é utilizar essas noções de forma heurística. Não se trata de emancipar a coisa associando-a aos humanos, nem tampouco afirmar a priori o que ela é, mas simplesmente marcá-la heuristicamente como uma forma vazia, pronta para ser preenchida etnograficamente. Tratar o digital como coisa nesse sentido, não é negar a mútua imbricação entre pessoas e dispositivos digitais, mas desentranhá-los heuristicamente das pessoas para que possam contribuir para sua própria definição conceitual e, portanto, para o deslocamento dos termos em que normalmente têm sido estudados (HOLBRAAD; PEDERSEN:215). Adotar uma abordagem ontologicamente inspirada do digital é, então, agir como se os dispositivos digitais operassem formas de ser que atuam na constituição e configuração dos modos de existência dos sujeitos. O objetivo analítico, no entanto, não é descobrir e dissecar as propriedades do digital mas, antes, investigar os seus efeitos no emaranhado da práxis dos sujeitos políticos, o que não implica, de modo algum, determinismo unilateral, como na visão tecnoessencialista de que a vida social está paulatinamente sendo moldada por fórmulas algorítmicas.

Entender o digital na perspectiva aqui endossada também implica situá-lo no horizonte mais amplo de uma cosmopolítica, ou seja, da sua articulação com outros entes na composição de um mundo comum (STENGERS 2014). Comum aqui não tem o sentido de um compartilhamento de um conjunto de ideias que poria de acordo os agentes, mas de uma união, muitas vezes contingente, entre humanos e humanos e não-humanos em uma coletividade sem forma fixa ou acabada, um 'viver-junto'. Trata-se, portanto, de um arranjo sem garantias, que se reveste de certo senso de precariedade e necessita ser continuamente renegociado por estar sempre sujeito à contestação. Levar a sério o desafio posto pela articulação entre heterogêneos requer necessariamente o reconhecimento da imanência do conflito e exige um olhar sensível para as recalcitrâncias, as divergências e os desacordos entre os agentes, o que afasta essa abordagem de uma tendência ainda 
muito persistente nas análises antropológicas para ignorar e subestimar as múltiplas vozes discordantes a fim de garantir a coerência e solidez de suas interpretações.

$\mathrm{Na}$ sequência deste capítulo veremos como a arquitetura e o funcionamento dos ambientes digitais incidiram diretamente e diferencialmente sobre as práticas dos cidadanistas da Raiz e sobre os modos de pensarem a política, especialmente em relação a alguns conceitos que têm balizado grande parte do debate sobre democracia, como os conceitos de autonomia, horizontalidade, representação etc. Essa influência, no entanto, não estava isenta de tensões e contradições e mostrarei como, por um lado, o digital promovia dinâmicas que reforçavam os pressupostos ontológicos que estão na base do pensamento sociopolítico ocidental e que, por isso, muitas vezes essas dinâmicas entravam em choque com os princípios defendidos pelo coletivo. Por outro lado, veremos que as suas práticas digitais também continham elementos que desafiavam alguns desses pressupostos e os dualismos que lhes estão normalmente associados, a começar pela oposição entre o real e o virtual, um dos dualismos fundadores dos estudos sobre o digital. (BOELLSTORFF 2016).

\subsection{O real e o virtual}

A maior parte dos estudos contemporâneos em tecnologia ainda está fundada na oposição real/virtual. Embora essa oposição tenha sido cada vez mais abalada pelas práticas que transpassam essa fronteira, subsiste fortemente a ideia de que o virtual (digital) é irreal ou tem um estatuto de realidade precário. As práticas da Raiz frequentemente embaralhavam ou dissolviam essa fronteira, embora no plano discursivo ainda houvesse referências ocasionais a um mundo real (das relações autênticas, afetivas, face a face) em oposição a um mundo virtual (frio, falso, irreal, incompleto). Essa oposição foi sendo cada vez mais nuançada, na medida em que o online se tornou o centro para onde convergiu grande parte das atividades do coletivo. Assim, os debates, as resoluções, as propostas e as votações passaram a ser centralizados na plataforma digital, de modo que, em certo sentido, é possível afirmar que o mundo digital era mais real do que o mundo desconectado. Em muitas situações não se sabia exatamente se uma ideia, uma discussão, uma proposta, uma aliança surgiu no âmbito virtual ou fora dele, o que não importava, bastava apenas que essas ações fossem direcionadas posteriormente para o debate público, no ambiente digital. Uma conversa em um espaço de discussão online não era um simulacro de diálogo ou uma conversa que precisava ser 
atualizada (por um diálogo mais genuíno) no mundo real ou, dito de outro modo, a realidade estava cada vez mais deixando de ser, para esses agentes, uma propriedade que distingue o online do presencial (BOELLSTORFF 2016:397). Em muitos casos, os modos de organização e registro online contribuíram e serviram como modelo para a formação de uma espécie de cultura do registro, que se difundia por múltiplas práticas do coletivo. Nos espaços de discussão online não era raro que declarações pretéritas de membros do movimento fossem recuperadas e reproduzidas ipsis litteris, enquanto que as reuniões offline (presenciais), paulatinamente, adotavam o hábito do registro sistemático dos encontros. Deste modo, era preciso registrar, simplificar, classificar e dispor esses encontros em formato digital (em ordem cronológica, na categoria mais adequada da página e em lugar facilmente acessível), o que também incidia diretamente na organização e na dinâmica das reuniões presenciais (organização do espaço, opção pelo uso de equipamentos de captação de som e registro audiovisual, coordenação das falas etc.); a realidade do presencial também passava a ser (re)definida pela realidade do digital.

Mesmo o 'fazer-junto', produtor de certo senso de coletividade e que era frequentemente visto como um traço distintivo do presencial, podia ser reconhecido na elaboração conjunta online de documentos (como o estatuto e o regimento da associação), na dedicação a uma causa (como, por exemplo, na mobilização em rede contra o impeachment da ex-presidenta Dilma Rousseff) ou na resolução de um problema (criação de um método para redigir o estatuto). Essas ações colaborativas online contribuíram para a produção da coletividade e para a emergência de novas formas de solidariedade, ressaltando, ao mesmo tempo, a singularidade dos sujeitos com suas potencialidades criativas.

De acordo com o que foi exposto, fica claro por que a dicotomia real/virtual mostra-se bastante problemática para pensarmos essas práticas, ao passo que os termos opositivos online, offline (ou presencial) ${ }^{14}$ servirão aqui, antes, como suporte explicativo, para facilitar o funcionamento da heurística aqui proposta. Também não é o objetivo deste capítulo partir de uma definição sistemática do digital. Para os fins aqui pretendidos, o digital deve ser entendido como uma série de dispositivos eletrônicos de processamento, transmissão e armazenamento de informação que operam por meio de entidades discretas (código binário) e que podem ser concebidos para projetarem imagens em ecrãs, promovendo assim a máxima interação com (e entre) os agentes que os operam como, por exemplo, computadores, tablets e smartphones - dispositivos

14 Na realidade o offline não se opõe ao digital, mas diz respeito à ausência de conexão em rede. Como não tenho interesse no offline digital, faço, para fins didáticos, a equiparação do offline às interações presenciais, correspondência que também se fazia presente nos discursos de alguns interlocutores. 
utilizados pelos sujeitos dessa pesquisa. $\mathrm{Na}$ verdade, muitos desses aparelhos podem também incluir em sua composição dispositivos analógicos (que representam a informação por meio de variações contínuas, sem conversão binária, ou seja, por analogia direta), especialmente no caso de computadores. A forma que o digital assume no momento em que é acionado ou operado por um sujeito é o resultado de um agenciamento muito complexo que inclui o movimento dos elétrons nos circuitos dos dispositivos, os códigos de programação, o desenho das plataformas (que inclui a disposição dos elementos no ecrã e a sua estética), o ambiente sociocultural geral, condições econômicas de acesso às tecnologias, a forma e o nível de instrução educacional e digital, a legislação dos Estados, questões éticas etc.

O uso que faço dos termos espaço e ambiente para descrever as formas que o digital adquire nas telas dos aparelhos não se deve, pura e simplesmente, a uma adoção automática de termos de uso comum entre os ciberagentes ${ }^{15}$, mas é consequência do próprio modo como os sujeitos experimentavam essas tecnologias. Quando um agente lia uma mensagem em um tópico de discussão e, em seguida, escrevia e publicava outro texto em resposta a esta postagem, ele não via essa sucessão de mensagens na tela como um mural onde pessoas situadas em diferentes lugares deixavam seus recados para serem lidos quando outros fossem acessá-los. O Fórum de Discussão era vivenciado como um espaço de interlocução onde os sujeitos se encontravam e interagiam como se não existissem os diferentes tempos e lugares nos quais acionavam seus artefatos digitais. $\mathrm{O}$ espaço era, portanto, menos a sala da casa ou o escritório onde os agentes estavam digitando suas mensagens, do que os retângulos brancos dispostos em sequência em um fundo acinzentado que constituíam os verdadeiros lugares ou ambientes onde ocorriam os encontros políticos do digital.

15 Uso o termo ciberagente para me referir ao agente que interatua com dispositivos digitais. Possui um sentido mais específico em relação à agente, por um lado, e em relação à internauta e cibernauta, por outro. Dentro da perspectiva aqui endossada, o conceito poderia muito bem ser utilizado para fazer referência a outros agentes nãohumanos, como robôs e dispositivos tecnológicos, embora neste capítulo eu o restrinja apenas aos humanos. 


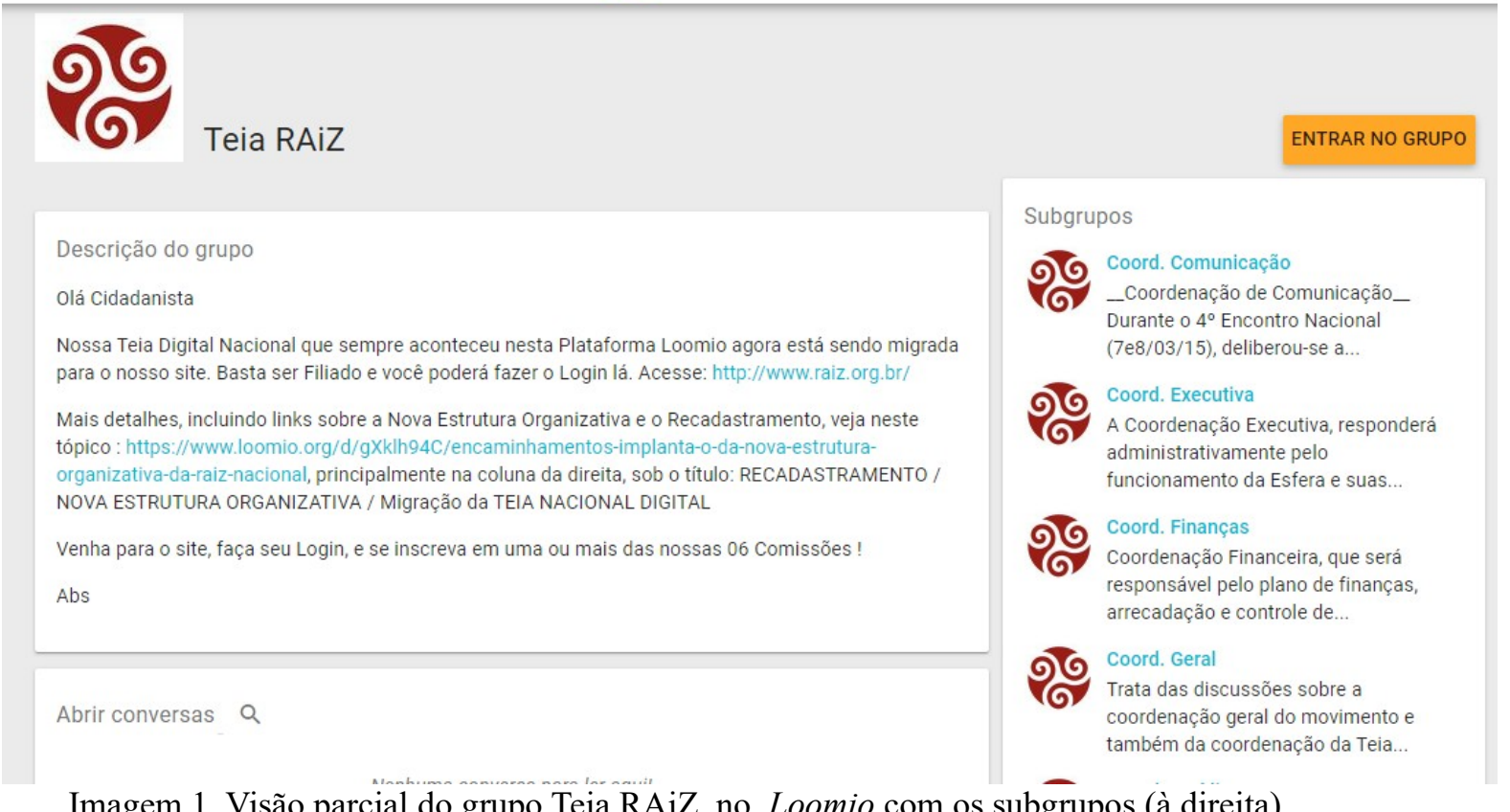

Imagem 1. Visão parcial do grupo Teia RAiZ no Loomio com os subgrupos (à direita).

\subsection{Digitalizando a política}

A plataforma Loomio é uma aplicação web que utiliza código aberto e foi criada por iniciativa de ativistas do movimento internacional Occupy com o intuito de promover a participação das pessoas em processos decisórios (MCKENZIE 2013). Em 2014 o projeto captou cem mil dólares via financiamento colaborativo (crowdfunding) e lançou a versão Loomio 1.0 para desktop e, depois, para dispositivos móveis. O Loomio é desenvolvido e mantido por uma empresa social (além de desenvolvedores-colaboradores espalhados pelo mundo) e financiado por contratos com empresas, instituições da sociedade civil, governos e doações de usuários. Baseado em software livre, sua filosofia pressupõe liberdade de uso, modificação e compartilhamento, estando, portanto, alinhado com os valores de vários coletivos que o adotaram ao redor do mundo, como o partido Podemos espanhol, o Partido Pirata (na Grécia, Chile e Bélgica), o movimento britânico Students for Cooperation, entre muitos outros.

O Loomio está organizado a partir do conceito de grupo. Um grupo pode ser criado, por exemplo, pela iniciativa de um membro de uma associação que, como administrador, concede permissão para o ingresso de novos membros e novos administradores. A partir desse grupo 
principal são criados subgrupos e dentro desses subgrupos os usuários cadastrados podem criar tópicos de discussão dentro dos quais qualquer participante pode publicar comentários e encaminhar propostas para serem submetidas à votação e cujo resultado é resumido em um gráfico circular. A Raiz estava organizada no Loomio da seguinte forma: havia um grupo principal (que funcionava como a página inicial da Raiz na plataforma) onde eram realizadas as deliberações do coletivo e que correspondia à instância da Raiz chamada Teia Digital; dentro deste grupo havia os subgrupos, que correspondiam às instâncias Coordenadorias e Esferas (regionais). ${ }^{16}$ Segue uma reprodução do Loomio da Raiz.

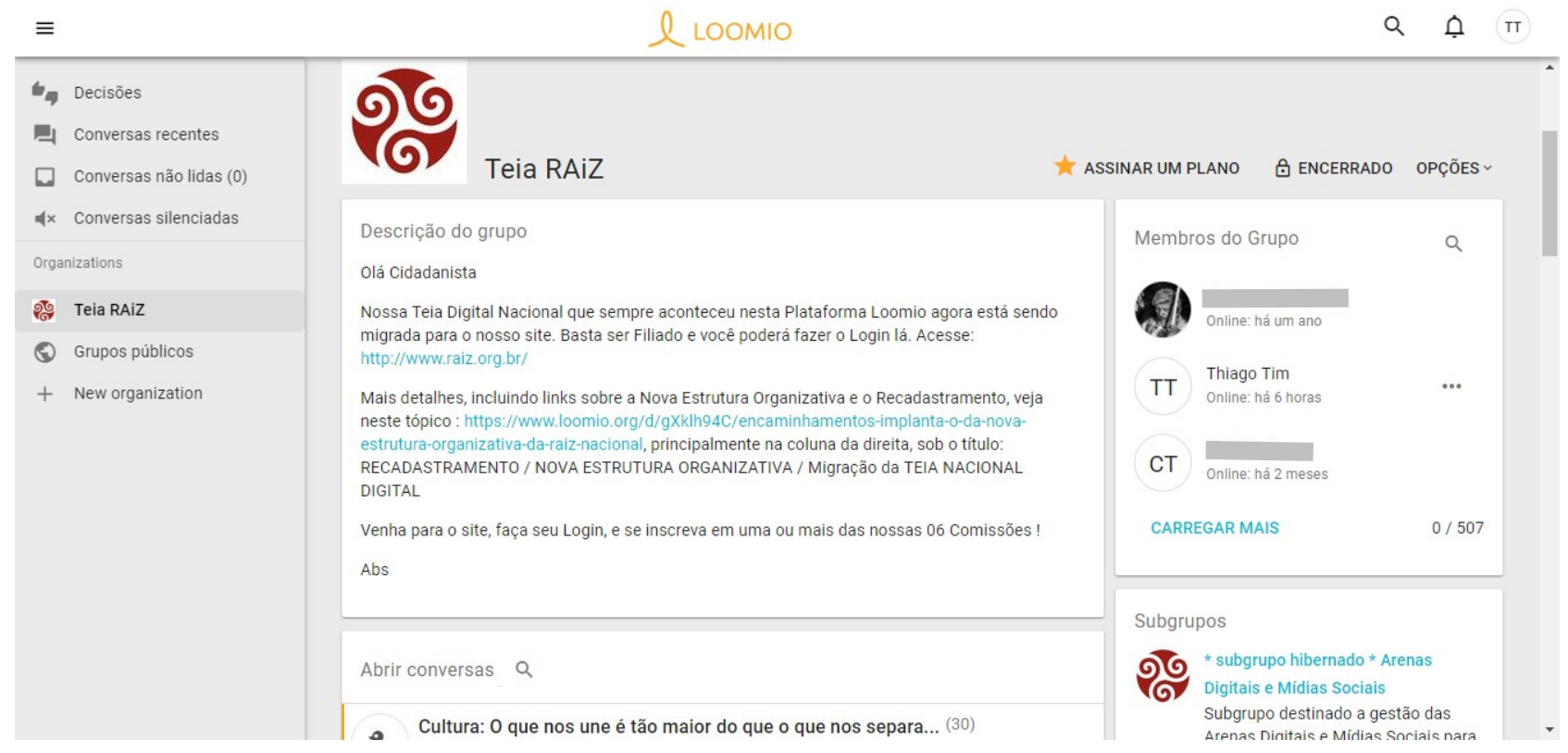

Imagem 1.1. Visão parcial do grupo Teia RAiZ no Loomio.

16 No ano de 2017 a Raiz abandonou o Loomio (embora ainda possa ser acessado por aqueles que possuem login no antigo grupo da Raiz) e migrou para uma plataforma própria, desenvolvida dentro da sua página oficial. 


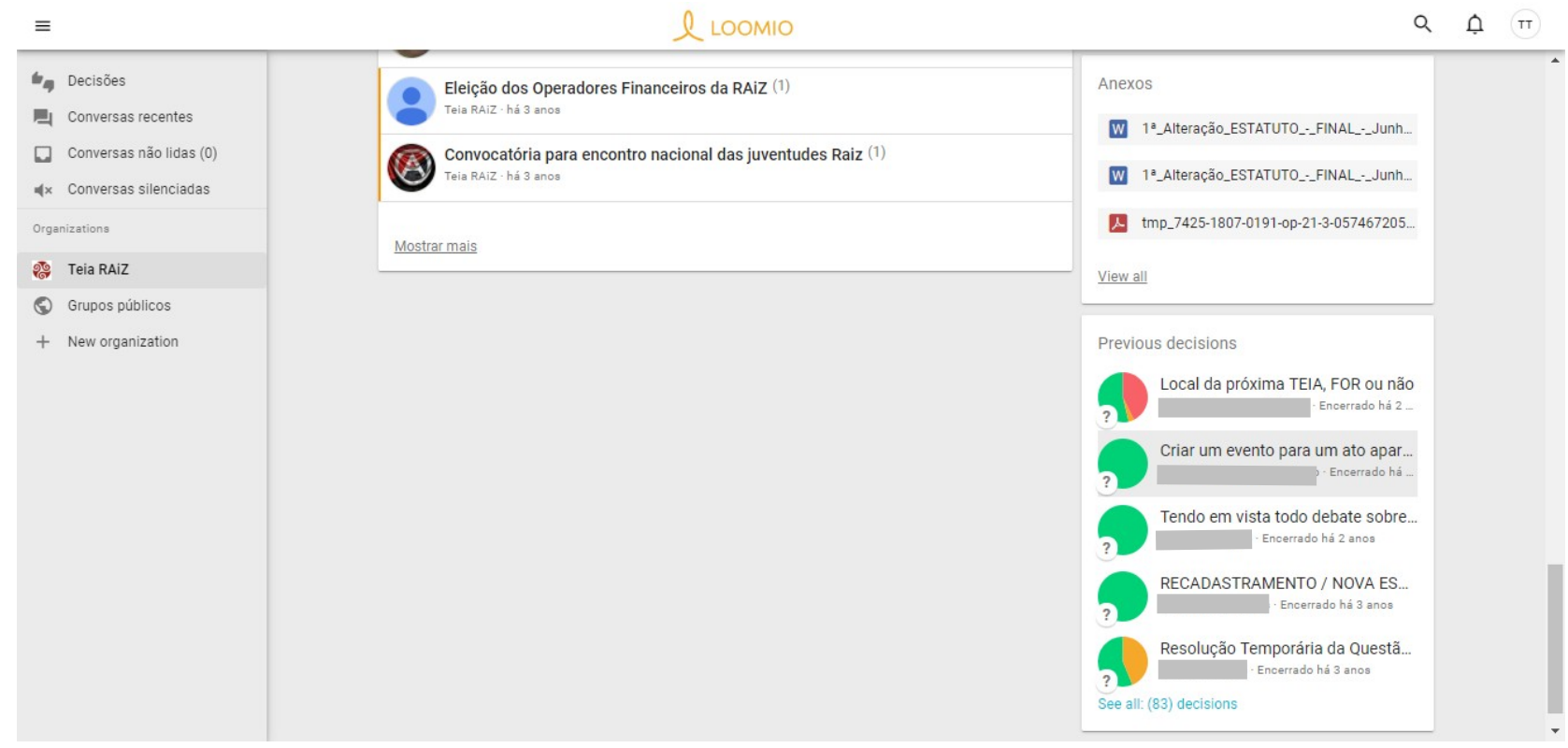

Imagem 1.2. Visão parcial do grupo Teia RAiZ no Loomio (zona inferior da página, incluindo as seções Anexos e Previous Decisions).

A estrutura da plataforma era basicamente dividida em três colunas:

1. Na primeira coluna (inteiramente na cor cinza, à esquerda) havia um menu vertical com links que serviam como atalhos para as decisões e conversas, na seguinte sequência: Decisões; Conversas Recentes; Conversas não lidas; Conversas silenciadas; e abaixo uma segunda seção (Organizations) com links para os grupos nos quais o usuário estava cadastrado, para grupos externos e para criação de novos grupos (Teia Raiz; Grupos Públicos; New organization).

2. A segunda coluna, localizada centralizadamente e de maior largura, apresentava em destaque o símbolo da Raiz com o nome do grupo ao lado em um fundo cinza (Teia Raiz) seguido por seções descontínuas, cada uma das quais delimitada por um retângulo de fundo branco. A primeira seção (Descrição do grupo) foi concebida para a descrição do 'grupo-web', mas vemos aqui que ela foi utilizada para postar uma mensagem para os seus membros-usuários. Logo abaixo tinha uma seção com todas as conversas realizadas, identificadas pelo título (com nome do grupo logo abaixo em fonte tipográfica de tamanho menor e informando a distância temporal em relação ao presente) e organizadas em sequência cronológica. No topo da seção havia um campo para pesquisa, identificado 
pelo ícone de uma lupa, onde o usuário poderia realizar uma busca por postagens escrevendo palavras ou frases (que poderiam estar no título ou no corpo do conteúdo).

3. Na terceira coluna, de largura bem menor que a anterior, havia quatro seções retangulares descontínuas em fundo de cor branca. A primeira seção (Membros do grupo) mostrava os últimos usuários que estiveram online (em ordem temporal decrescente) em relação ao número total de cadastrados (507) e permitia a busca de membros do grupo. Na segunda seção (Subgrupos) encontravam-se os links para os 15 subgrupos criados, subdivididos em Coordenadorias (11), Esfera Nacional e grupos com temas específicos (4), um deles com o título iniciado por GT (Grupo de Trabalho). Na terceira seção (Anexos) havia links para os documentos, textos e imagens adicionados no repositório de arquivos disponibilizado pela plataforma. Na quarta seção (Previous decisions) os ciberagentes encontravam os links que davam acesso aos resultados das decisões tomadas por meio de votação, já com os seus respectivos gráficos circulares em miniatura.

Acima da terceira coluna, três links destacavam-se em sequência horizontal: um link para assinatura de um dos planos pagos do Loomio (Assinar um plano) e dois links com opções de configuração (Encerrado e Opções). O limite superior da página era demarcado por uma barra (uma faixa retangular branca que cortava horizontalmente todo o topo da página) e o interior desse retângulo acomodava um botão à esquerda (em forma de três linhas paralelas na cor preta) que, quando clicado, ocultava e tornava visível a primeira coluna; no centro da faixa, era possível ver, em destaque (na cor laranja), o logotipo do Loomio e no canto direito havia, na cor preta: um ícone em forma de lupa para busca de termos na plataforma; um ícone (em formato de sino) onde era mostrado o número de notificações do grupo e que deveria ser acionado para verificá-las; e um botão (um círculo com as iniciais do nome de usuário no interior) que dava acesso a configurações do usuário.

Ao clicar em um dos 'botões-link' das conversas iniciadas, na coluna do meio, o usuário era direcionado ao espaço de discussões com duas colunas, reproduzido nas imagens 2 e 2.1. Na imagem 2 há, na coluna principal, à esquerda, o título e a proposta de discussão e logo abaixo (em letra de tamanho reduzido) o nome do proponente, datação (há 3 anos), status da conversa (privada) e o número de pessoas que visualizaram a página da conversa (Seen by 204). Na sequência (imagem 
2.1), logo abaixo, há as participações dos outros membros, com nome e data no topo e após o espaço destinado à escrita, no canto inferior direito, há três botões: o primeiro permitia adicionar um emoticon ${ }^{17}$ que poderia ser selecionado em uma lista de vinte possibilidades e que apareceria no canto inferior esquerdo da mensagem junto ao nome daquele que o escolhesse (na imagem temos três reações positivas à mensagem dos interlocutores); o segundo botão consiste numa seta virada para a esquerda e que, quando acionada, permitia escrever uma resposta à postagem localizada imediatamente acima dela; por último, o terceiro botão (com a imagem de elos de corrente) permitia inserir na mensagem links para quaisquer ‘endereços-web’ escolhidos.

$\mathrm{Na}$ coluna da direita, de largura menor (imagem 2), podemos ver uma seção com um campo para busca de membros da conversa (com um ícone da lupa na extremidade direita) e uma seção logo abaixo (Previsisous decisions) com o resultado da consulta (por meio de votação), aos participantes da conversa, sintetizado por um gráfico circular. A maior parte das discussões não encaminhava resoluções para votação, por isso, nesses casos, esta seção estava ausente.

17 Emoticon é um termo derivado da junção das palavras inglesas emotion e icon. Trata-se de uma imagem de um ente de aspecto lúdico, geralmente amarelo e em forma de círculo, cuja expressão foi inspirada nos traços característicos das expressões faciais humanas e que serve para transmitir uma reação, emoção ou estado

psicológico, como no exemplo a seguir de um emoticon alegre: $\because$. Teve sua origem a partir da combinação de caracteres tipográficos, identificados com expressões faciais como, por exemplo: :) (dois pontos seguidos de um parêntese para expressar alegria). O primeiro registro de uso de caracteres com intuito de representar expressões faciais tem sido erroneamente atribuído ao jornal New York Herald Tribune, em 1953 (EMOTICON 2019), mas há fontes que mostram sua aparição em setembro de 1893, em um jornal de uma pequena vila belga (MAUMUS 2017). Com o advento dos dispositivos digitais e depois da internet o emoticon se tornou um ente característico e onipresente nas plataformas digitais. Os emoticons têm importância ainda bastante subestimada nos estudos sócioantropológicos dos espaços digitais, restringindo-se, quase que exclusivamente, ao campo dos estudos da linguagem e comunicação. 


\section{Frente POVO SEM MEDO}

Pessoal, algumas pessoas da RAIZ acho que chegaram a ir ao lançamento da Frente Povo Sem Medo. Chegou a rolar alguma conversa?

A FPM está convocando junto com a Frente Brasil Popular as manifestações do dia 31 Pela leitura superficial que fiz, a Povo Sem Medo vai mais além do governismo da maioria da FBP e aglutina também alguns setores da oposição de esquerda, razão pela qual acho que seria um espaço interessante para somarmos forças com outros movimentos para construir uma alternativa não-conservadora para o Brasil.

0 que acham? A RAiZ deveria fazer parte de uma das frentes? Das duas? De nenhuma?

Deixo abaixo a carta da FPM:

CARTA CONVOCATÓRIA DE LANÇAMENTO DA FRENTE POVO SEM MEDO

0 mundo vive sob o signo de uma profunda crise do capitalismo, que perdura desde 2008 . Medidas de austeridade econômica dominam a agenda política, multiplicando desemprego, miséria e redução dos direitos trabalhistas. Por outro lado, os banqueiros comemoram cada aniversário da crise, aumentando seus já exorbitantes lucros.

No Brasil, as medidas econômicas não deveriam seguir o mesmo script. O "ajuste fiscal" do governo federal diminui investimentos sociais e ataca direitos dos trabalhadores. Os cortes na educação pública, o arrocho no salário dos servidores, a suspensão dos concursos são parte dessa política. Ao mesmo tempo, medidas presentes na Agenda Brasil como, aumento da idade de aposentadoria e ataques aos de direitos e à regulação ambiental também representam enormes retrocessos. Enquanto isso, o $1 \%$ dos ricos não foram chamados à responsabilidade. Suas riquezas e seus patrimônios seguem sem nenhuma taxação progressiva. 0 povo está pagando a conta da crise.

Ao mesmo tempo, os setores mais conservadores atacam impondo uma pauta antipopular, antidemocrática e intolerante, especialmente no Congresso Nacional. Medidas como a

Previous decisions

Entrada da RAiZ na Frente Povo Sem Medo Encerrado há 3 anos

\section{Imagem 2. Frente Povo Sem Medo (tópico de discussão).}

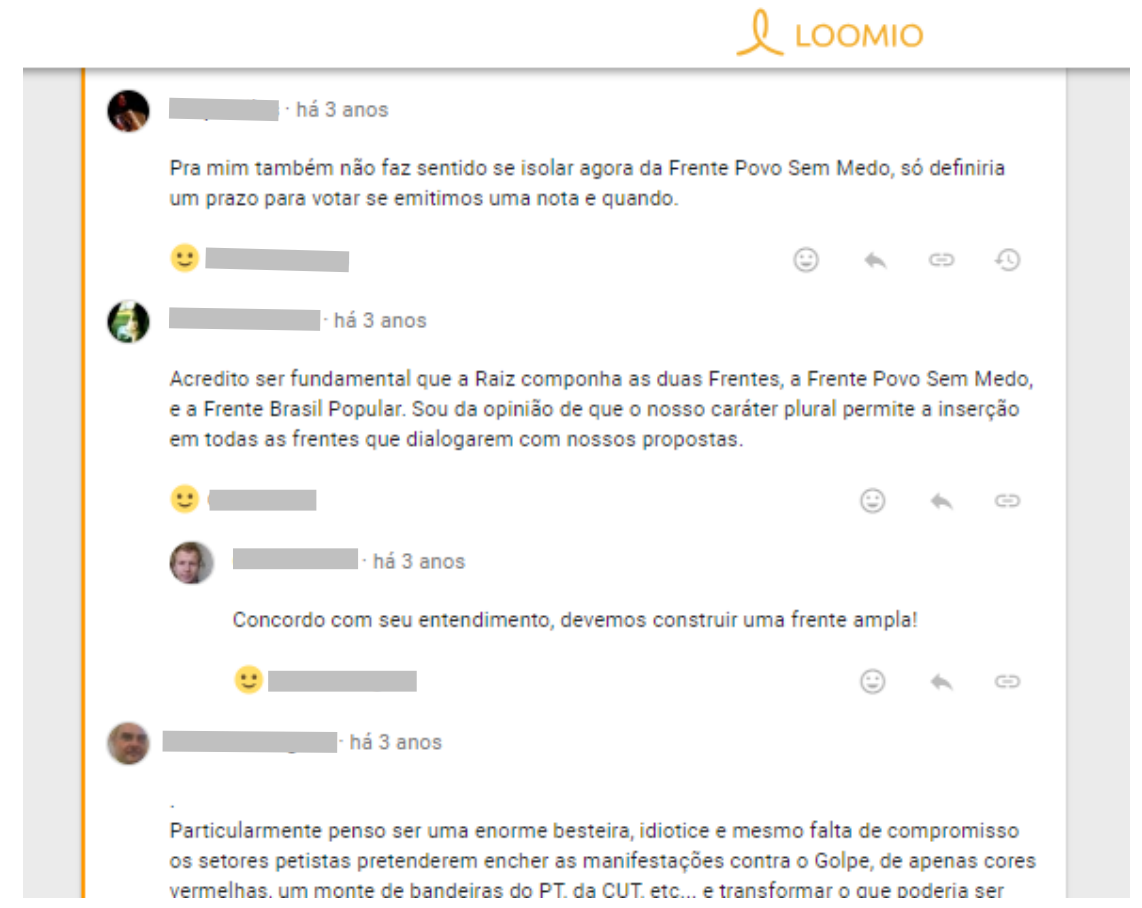

Imagem 2.1. Frente Povo Sem Medo (tópico de discussão - continuação). 
O espaço para votações do Loomio (imagem 3) possuía basicamente a mesma estrutura e desenho do espaço destinado às discussões, com campo para o título (que poderia ser diferente do título da discussão), identificação do proponente, data e texto de apresentação da votação e resumo dos encaminhamentos propostos pelo debate. Logo abaixo havia um gráfico circular com o número absoluto e os percentuais de votação nas categorias, no caso: Concordo 50 (90\%), Abstenção 1 (1\%), Discordo 4 (7\%), Bloqueio 0 (0\%). Em sequência, a imagem 3.1, mostra os votantes listados nominalmente com as opções escolhidas ao lado dos nomes e, abaixo, as justificativas das suas escolhas, que eram opcionais.

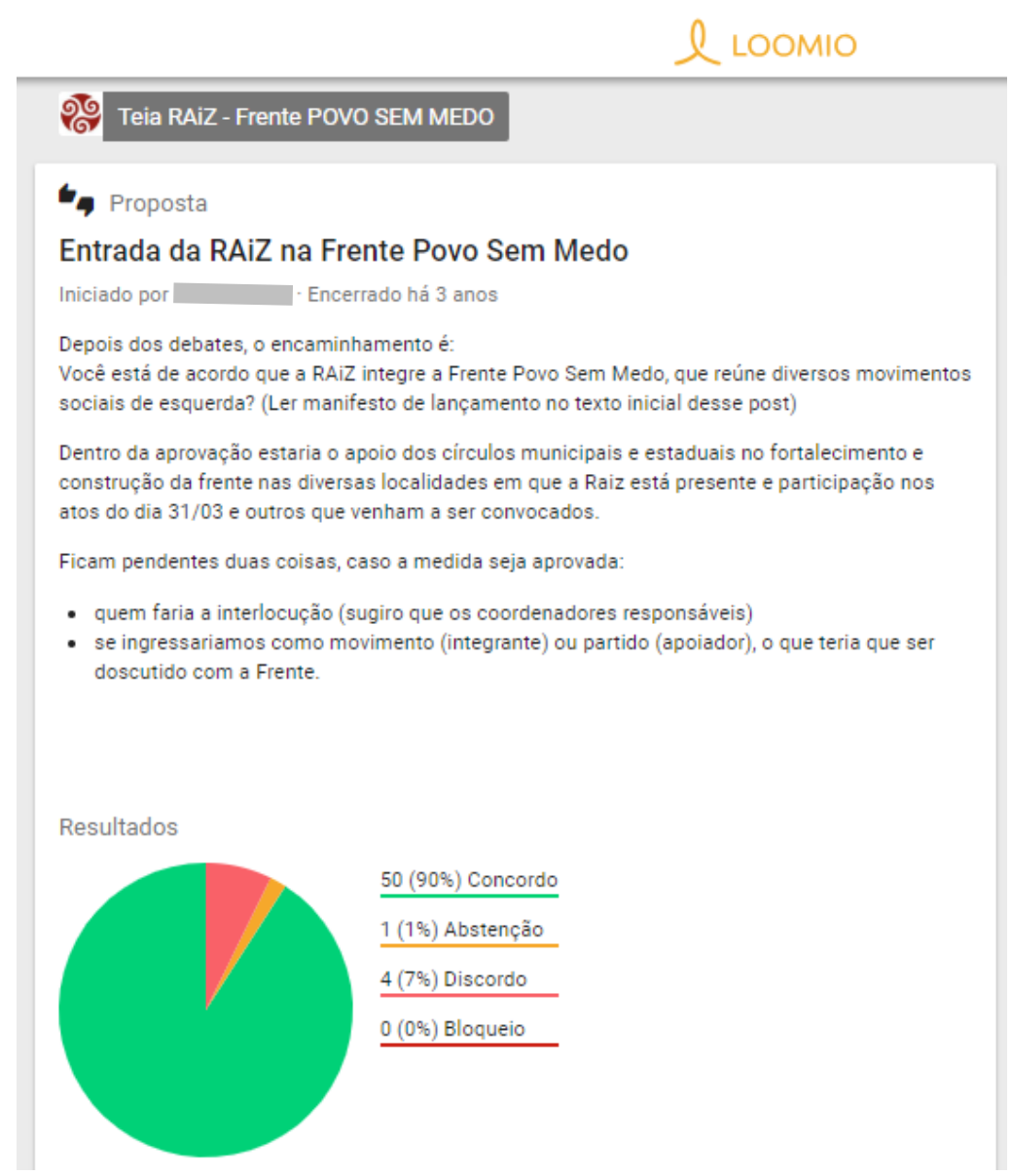

Imagem 3. Entrada da Raiz na Frente Povo Sem Medo (Proposta de votação e resultado). 


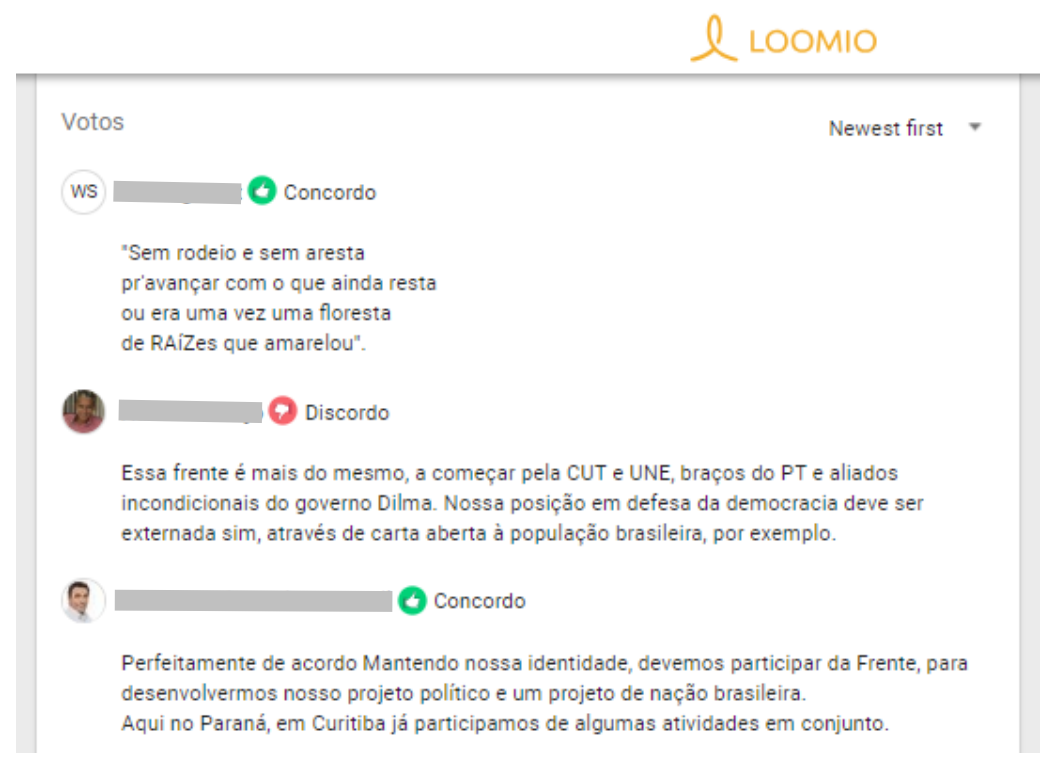

Imagem 3.1. Entrada da Raiz na Frente Povo Sem Medo (votos nominais, justificativas e comentários)

Ao avaliar a arquitetura do ambiente de votação e seu funcionamento fica evidente que a tomada de decisão na forma de escolha entre categorias (concordância, abstenção, discordância e bloqueio) impunha dinâmicas muito particulares e limitações profundas ao processo decisório. Além da limitação radical das possibilidades de escolha, nota-se uma tensão fundamental entre o modo como a ferramenta funciona e o princípio da busca pelo consenso defendido pelo coletivo. A reclamação de Aruan Canola ia nesse sentido:

Ao se fazer uma votação, aqui no Loomio, deve-se primeiro ter um debate acumulado sobre abrir ou não a votação, e em que moldes. Este vício Facebooquiano de ficar abrindo Enquetes, de forma individual (ista), sem um acúmulo coletivo anterior, falseia a questão democrática. Cria um efeito Manada, em que as pessoas se sentem compelidas a votar, muitas vezes sem qualquer vínculo mais profundo com aquilo, e várias vezes a revelia de todo o acúmulo que pode ter havido em um debate.

Mesmo que sempre houvesse discussões antes das votações e embora o Consenso Progressivo não descartasse o voto, ele deveria ocorrer apenas como último recurso - embora, muitas vezes, essa regra não fosse observada - e, além disso, o formato do ambiente de discussão (sequenciamento cronológico de mensagens) $^{18}$ dificultava o estabelecimento progressivo de convergências. O dispositivo de votação foi arquitetado segundo uma lógica de divisão, que dividia os votantes em posicionamentos opostos, ao passo que sua ideia de consenso supunha uma lógica

18 Havia outras opções para ordenação das mensagens, o que me parece pouco relevante em se tratando da mudança de resultados, acredito até que maximizariam os efeitos supracitados. 
que permitisse e promovesse alinhamentos e que as divergências fossem explicitadas em suas nuances. A existência de um botão de bloqueio provocou debates acirrados em torno dos significados de se bloquear uma votação e sobre o papel do dispositivo na promoção de participações descompromissadas com práticas mais construtivas. As falas de Aruan e Daniel iam ao encontro de outras manifestações nesse sentido:

A questão da responsabilidade de quem "bloqueia". Pois feita de forma banal, apenas representa boicote a decisões coletivas [...] Portanto, tendo-se responsabilidade ao abrir uma votação, ou seja, vota-se apenas quando ela é necessária, e tendo-se os termos consensuados, sou a favor de considerar o Bloqueio apenas como mais um voto contra. Simples assim.

Concordo com vocês, realmente é algo bem delicado mesmo... mas penso que deixar como está também não facilita o processo. Imaginem um monte de pessoas diferentes entrando neste grupo e, antes de entender direito os processos, podem ficar bloqueando tudo.

A partir do teor dessas e outras discussões também fica claro que, a despeito de ter sido uma possibilidade adicional de escolha, a opção bloqueio favorecia uma lógica de divisão, uma vez que indicava o não-alinhamento com outros pontos de vista por meio de uma marca, sujeita sem dúvida a diversas interpretações, mas seguramente mais próximas dos sentidos relacionados à disjunção. Ademais, a configuração do dispositivo em termos de opções de escolha teve como efeito estimular a introdução de descontinuidades no espaço social e a promoção de uma 'metafísica da escolha', sobre a qual parecem estar fundadas a democracia representativa (onde o cidadão escolhe livremente seus representantes) e a lógica do neoliberalismo (no qual o consumidor escolhe produtos, serviços e empregos no mercado). Ao que parece, a política forjada nesses espaços tendia a reproduzir e exacerbar aspectos-chave do modelo político que, para meus interlocutores, era objeto de contestação, na medida em que esse formato da plataforma privilegiava o lugar da escolha - sobretudo pelo seu caráter, predominantemente, terminativo e por ser realizada entre opções estanques e acabadas - na constituição do processo democrático.

A forte rejeição ao Facebook como espaço deliberativo se revelou ainda quando a Raiz era Avante e o processo de escolha do nome da Raiz mostrou como o funcionamento da rede social podia limitar de diversas formas a realização dos princípios mais caros ao coletivo. $\mathrm{O}$ fato do Loomio só permitir a concordância, discordância, abstenção e bloqueio de propostas fez com que o Facebook fosse adotado como plataforma para a escolha do nome da associação, após uma reunião 
presencial no Rio de Janeiro onde houve a primeira seleção de nomes. Grosso modo, a votação se deu por meio de enquetes de caráter consultivo ${ }^{19}$ a partir dos nomes elencados no Loomio, na reunião presencial e no Facebook. Cada votante tinha direito a escolher três nomes e, encerrada a enquete, outra era realizada com os nomes mais votados na anterior (afunilamento de nomes) e a inclusão de novos nomes, até a decisão final no encontro em São Paulo. O primeiro problema que vale a pena destacar é que a seção de comentários do Facebook não foi projetada para promover o diálogo e a construção argumentativa, o que tornava muito difícil acompanhar um debate: o crescimento do número de mensagens fazia da localização de um trecho do debate uma tarefa bastante árdua (as mensagens eram escritas em semi-retângulos azuis de cantos arredondados e empilhadas umas sobre as outras em letra de tamanho pequeno); as mensagens com mais comentários e curtidas ficavam em destaque (pois estavam organizadas na configuração padrão como mais relevantes); ao selecionar a opção para mostrar todos os comentários (o que seria o esperado em um debate), ainda assim, eles não apareciam em ordem cronológica, mas em ordem de relevância. O que o usuário via, portanto, era uma grande sequência de mensagens (que facilmente chegava a dezenas) com pouca conexão lógico-semântica entre si. Outro problema era que o modelo de enquete fornecido pelo Facebook, ao apresentar em destaque o dispositivo de votação (mostrando logo de cara um gráfico de barras horizontais com os mais votados), já conduzia o ciberagente à votação, enquanto que o espaço de debate ficava localizado em um campo de visualização secundário, aliás, o que aparecia na tela era o campo para mensagens com a inscrição comentários, tornando a ideia de discussão e argumentação ainda mais distante. Esses problemas foram muito bem sintetizados na reflexão feita por Miguel Vieira, em uma conversa iniciada no Loomio para discutir a escolha do nome.

\footnotetext{
Não acredito em consensos absolutos, em unanimidade, mas acredito em processos que busquem a consensuação, através aproximações argumentativas e busca de entendimentos. E estes processos com certeza não se realizam estimulando votações e votações, em uma plataforma pobre como o Face, onde qualquer argumentação vai se perdendo em meio a dezenas e centenas de postagens. Não se produz acúmulo de debate, não se conversa. Apenas se vota, se compete. Lamento os últimos encaminhamentos sobre a escolha do Nome, questão de suma importância. Estamos perdendo a oportunidade de praticarmos aquilo que falamos.
}

19 A consulta aqui não funcionava como mera sugestão, pois ela tinha um caráter seletivo-eliminatório que já era, em si, decisivo. Portanto, é preciso ter cautela com a oposição consultivo/decisório e outras oposições muito arraigadas e que podem levar a interpretações equivocadas. 
A reflexão de Miguel ainda chama a atenção para a degeneração do consenso em disputa, uma dinâmica intimamente relacionada à metafísica da escolha e com efeitos radicalmente opostos ao que o coletivo esperava. Muitos votaram sem deixar qualquer comentário, sem nem mesmo terem participado de discussões anteriores, enquanto outros escreviam comentários incitando os votantes a lhes seguirem em suas escolhas, isso quando não ridicularizavam as outras opções concorrentes, recorrendo até mesmo a insultos para desqualificar os defensores de outros nomes. A ferramenta curtir disponibilizada pelo Facebook, que permitia manifestar o apoio ou elogiar uma postagem na rede social, também contribuiu para configurar um ambiente de disputas e dividir os agentes, a ponto de Álvaro se queixar de gente que ficava abordando as pessoas em função de curtidas. ${ }^{20}$ A manifestação de Júnior tinha o mesmo teor das reclamações dos seus interlocutores:

Bia, a questão não é preferência por A ou B, o que percebo são pessoas tentando desqualificar o nome $\mathrm{A}$ ou B e não tentando compreender o outro lado; Outra coisa que percebo, são ataques gratuitos, principalmente de pessoas que nem temos ideia de quem são, comprometimento zero. As facilidades do mundo virtual pode ser uma bomba, abrir o computador, conectar na internet e digitar, é fácil, quero ver é fazer o movimento, fazer o doce, só isso =) Abraços

Sem dúvida, a facilidade em participar da votação no Facebook (ao ver a votação no mural de notícias bastava efetuar um clique), permitia que qualquer participante do 'grupo-web' votasse em segundos, sem sua atuação implicar qualquer compromisso, inclusive, poderia até assumir um caráter lúdico. Já no Loomio, as coisas se passavam de maneira algo distinta: a participação no Loomio da Raiz requeria um cadastro e os membros cadastrados já estavam, em sua maioria, familiarizados com o fato de ali se tratar de uma plataforma para discussão e deliberação política.

Esse momento da escolha do nome também pôs em relevo o papel das emoções nessas disputas, pois as discussões estavam geralmente acompanhadas de grande animosidade: palavras e frases de incentivo em caixa alta, trocas de acusações, insultos, acarretando, até mesmo, o desligamento de membros do coletivo. Queixas em relação ao predomínio de afetos negativos nessas discussões foram muito frequentes e, em nenhum momento, consideradas impertinentes. Júnior confessou estar no limite em relação aos ataques sofridos na discussão dos nomes e que iria

20 Recentemente, a plataforma Instagram, no Brasil, deixou de mostrar o número de curtidas das publicações, informação geralmente utilizada para medir a popularidade das postagens e do perfil de um autor (agora esta informação está disponível apenas para o autor do conteúdo). Segundo a rede social a intenção da mudança - que por enquanto se resume a um período de testes -, é diminuir a competitividade entre os usuários e estimular interações mais saudáveis (ANDRION 2019). Em 2017, um estudo da Royal Society for Public Health, no Reino Unido, considerou o Instagram a pior rede social para a saúde mental dos usuários (BBC News 2017). 
começar a respondê-los com os quatro pés no peito do agressor. As emoções também se manifestavam no seu aspecto positivo, expresso, por exemplo, no vínculo afetivo presente na identificação com um dos nomes. $\mathrm{O}$ sentimento despertado por um nome era frequentemente reivindicado como argumento para a sua escolha, embora fosse algumas vezes mostrado como um elemento secundário. Entre os argumentos mais frequentes estavam aqueles que mostravam relação entre os significados evocados pelos nomes e aqueles associados à Raiz, como, por exemplo, o senso de união (Ciranda, Nós, Somos), de ecologia (Ecos, Raiz) ou de uma política diferente da tradicional (Movimento Cidadanista, Podemos, Livre). Outra justificativa comum era a suposição de aprovação e aceitabilidade da população. Contudo, é importante chamar a atenção para o fato de que esses significados acionados também estavam impregnados de emoções, embora nem sempre diretamente reconhecidas enquanto tais. Era comum nos discursos dos cidadanistas o reconhecimento de uma separação ontológica entre emoção e argumentação racional (sobretudo nesse primeiro momento formativo do coletivo), embora muitas vezes reconhecessem a necessidade de aproximá-las. Mas os significados associados à união, por exemplo, não eram puras entidades linguísticas, que colocavam em relação de homologia os princípios do coletivo e o nome Ciranda, mas eles estavam carregados de afetos que foram sendo conformados e reforçados nas múltiplas práticas coletivas desses sujeitos. Talvez seja em parte por essa razão que alguns mostravam tanta dificuldade em abrir mão de certos nomes, uma postura sempre reivindicada nesses debates (o desapego). Com o nome Ciranda é possível que tenha se passado algo do mesmo gênero. Talvez o fato do termo ter sido defendido com vigor por pessoas do meio cultural não foi apenas em razão de remeter linguisticamente a uma prática cultural popular, mas por evocar sentimentos bastante enraizados ligados a essa prática (um sentido poético chegou a ser relacionado ao nome) que poderiam, inclusive, ter relação com memórias de um passado feliz. Essas situações chamam a atenção para a necessidade de olhar com mais afinco para as emoções contidas nessas práticas a fim de se evitar que a análise social caia num árido logicismo linguístico.

$$
* * *
$$

A análise dos ambientes de discussão e votação do Loomio colocou em evidência elementos e dinâmicas que me parecem fundamentais para entender a forma dessas práticas, alguns já presentes no modo de funcionamento do Facebook, afinal de contas, ambas as plataformas têm arquiteturas que se assemelham em diversos aspectos. Uma das questões que se colocam de 
imediato na análise desses ambientes digitais é a respeito do papel dessas tecnologias na eliminação das vias mais radicais de expressão política. O encaminhamento dos debates do Fórum de Discussão para o espaço de votação no Loomio consistia numa operação drástica de eliminação, discretização, simplificação e uniformização e questões que apresentavam certo grau de complexidade (e muitas vezes com potencial político mais radical) para serem submetidas a uma consulta simples tendiam a ser reformuladas (nesse sentido da homogeneização e simplificação) ou desconsideradas. Nesse espaço os agentes precisavam se enquadrar em uma das quatro categorias existentes e figurar em uma tabela como mais uma unidade de voto vencedor ou vencido. As nuances argumentativas, a complexidade de cada posicionamento, a possibilidade de conhecer o outro, o apelo emocional etc., eram eliminados em proveito de uma realidade que tomava a forma de uma operação meramente lógica. A oposição sim (concordo) e não (discordo) eliminava uma série de graus de aproximação e afastamento, modulações discursivas, cláusulas de precaução etc., enquanto que divergências pontuais e facilmente negociáveis e divergências profundas e incontornáveis eram equiparadas em uma mesma categoria e o que se apresentava no final era o registro puro e simples da discordância.

Se, por um lado, os cidadanistas mostravam que o digital não podia, simples e unilateralmente, regrar o funcionamento do social - como a 'tecno-teologia' da grande inteligência algorítmica supõe -, por outro, as práticas digitais no Loomio também nos revelam as resistências interpostas pelos dispositivos digitais para funcionar segundo uma lógica do social. Os cidadanistas reconheciam ocasionalmente as limitações da arquitetura de software para implementar um modelo mais participativo e dialógico de organização política, mas os debates em torno do assunto mostravam claramente que partiam do pressuposto de que o digital poderia ser, em grande medida, moldado segundo intenções e objetivos sociais (embora reconhecessem a complexidade técnica da empreitada), premissa que tem sido moeda corrente nos estudos de tecnologia.

\subsection{Cosmopolitizando o digital}

As situações em que os agentes reconheciam as limitações das ferramentas eram sempre muito reveladoras e mostravam, como em uma lente de aumento, os modos de operação da ontologia do digital. A análise do período em que foi escrito o estatuto da associação é muito elucidativa nesse sentido. O documento começou a ser redigido no espaço de discussão da 
plataforma, onde as contribuições escritas eram dispostas em sequência cronológica. ${ }^{21}$ Partiram de um esboço da estrutura do documento para, em seguida, iniciarem a escrita dos itens que comporiam o estatuto. Assim que um determinado item era redigido e pré-aprovado pelos colaboradores, ele passava a fazer parte do texto que seria levado para votação. O fato é que o modelo de organização das discussões propiciado pela plataforma (chamado aqui de Modelo Fórum de Discussão) trouxe algumas dificuldades. A principal delas foi ocasionada pela disposição das participações na ordem em que foram postadas (cronologicamente), cujo efeito foi o empilhamento de mensagens e a dispersão das discussões de determinados itens do documento por diferentes partes do Fórum e a consequente dificuldade para o diálogo em torno de certos pontos específicos: uma discussão sobre um aspecto particular de um artigo era comumente sucedida por várias outras mensagens, podendo ser retomada, mas muitas vezes abandonada sem qualquer resolução. Esse modelo diacrônico e linear, embora permitisse, por sua natureza textual, a expressão individual contínua dentro de uma mensagem, gerava uma dificuldade imensa para se pensar o produto final da relação entre mensagens (o todo), o que teve como resultado a dispersão caótica dessas contribuições, em um movimento de discretização desordenada. Além disso, a entrada dos agentes nos debates em diferentes momentos fazia com que muitos não atentassem para o todo e passassem a atuar apenas com base em informações retiradas de fragmentos das conversas, ignorando todo um acúmulo prévio de discussão e transformando esses debates, muitas vezes, em algo parecido com aquela brincadeira conhecida como telefone sem fio.

A apresentação parcial da minuta do primeiro capítulo do estatuto para discussão coletiva foi feita voluntariamente por João Lucas. A minuta foi apresentada no Fórum de Discussão, em um tópico criado dentro do Grupo de Trabalho Construção Colaborativa do Estatuto, no Loomio. O texto continha os quatro primeiros artigos da seção I do estatuto que tratava da definição, objetivo, sede e símbolos da Raiz. O tópico foi configurado para ser visto apenas pelos cadastrados no Loomio e foi visualizado por 113 pessoas. O Fórum recebeu 153 postagens de 21 pessoas, mensagens que foram dispostas em sequência cronológica. A primeira mensagem, do Fernando Lames, versava sobre seis pontos relacionados à minuta e que abordavam, desde correções de nomenclaturas do texto, dúvidas sobre datas, processos e conceitos, até o encaminhamento de uma proposta de redação para um artigo. Apenas levando em consideração esse tópico, as seis questões propostas para discussão foram retomadas à medida que os interlocutores ingressavam na plataforma, sendo misturadas a uma infinidade de outras questões. Vemos, por exemplo, uma

21 Partes de alguns capítulos do estatuto foram escritas fora da plataforma e só depois submetidas para discussão e reformulação coletiva. 
questão aparentemente muito simples, sobre a necessidade de definir se a grafia do nome do partido incluía ou não o travessão: o correto seria Raiz Movimento Cidadanista ou Raiz - Movimento Cidadanista? Essa questão foi apresentada no primeiro tópico (no dia 10 de abril) e reapareceu nas mensagens das posições de número $2,11,14,16,44,45,48,49,50,53,55,57,120,121,125$ etc., terminando com a sugestão, na mensagem 125 (seis dias depois), para que ela fosse encaminhada como destaque para deliberação juntamente com outras divergências incontornáveis. Inúmeras outras questões apresentadas para discussão foram se misturando durante a conversa e acabaram sem apreciação, esquecidas no fluxo da diacronia.

A mistura e o vaivém de argumentos, a retomada da discussão de questões já consideradas encerradas e a proliferação de conversas pontuais que se desviavam do principal assunto em debate, eram frequentes no ambiente de discussão e, muitas vezes, desmotivavam a participação e a continuidade nos debates, como se queixou André:

Caros,

Primeiro: Novamente a discussão de forma e método num tópico de conteúdo. Este tópico é sobre o Capitulo 01 do Estatuto (...). Segundo: compreendo a motivação, mas é absolutamente claro que entraremos no Eterno Retorno. Minha nossa, depois de extenuantes debates se volta depois de um tempão (1 ou 2 meses...) para novas contribuições e é claro reabertura de debates... não é razoável (...) Nem vou me delongar mais. A cada passo de avanço, se volta dois pra trás, fica difícil.

O senso de descontrole propiciado pela experiência no Modelo Fórum parece ter contribuído para a formação de um conceito de democracia participativa como caótica e dependente de dispositivos de ordenamento (hierárquicos) para subsistir. O fantasma do caos nas assembleias nunca esteve totalmente ausente das falas dos cidadanistas, mas a forma como estava configurado o espaço de discussão parecia aumentar a magnitude e dar uma forma particular a essa ameaça. A partir da constatação reiterada dessas dificuldades, foi sugerida a utilização de um editor de texto para a escrita coletiva do estatuto (com marcação das intervenções, bem como a intermediação de sistematizadores) e, em seguida, a utilização de um dispositivo criado com o intuito de manter o foco no assunto em discussão e promover a participação e a transparência. Esse dispositivo foi construído com um editor de planilhas, estruturado em tabelas (em um aplicativo chamado Google Sheets) e merece destaque na medida em que foi proposto justamente para superar os limites da arquitetura da plataforma de discussão e por ter sido inspirado nos princípios políticos da Raiz. ${ }^{22}$

22 O dispositivo foi criado pelo cidadanista Alexandre Gerard a quem agradeço à gentileza de ter acolhido a ideia de falar sobre a sua invenção. Mesmo que o sistema de planilhas tenha sido considerado uma experiência malsucedida 
Nesse sistema, os itens e artigos do estatuto foram alocados sequencialmente nas linhas da segunda coluna (dentro da Coluna A), enquanto que cada coluna subsequente registrava a participação de um colaborador, como segue na Tabela 1 (Ferramenta para construção do consenso). Por ser uma planilha excessivamente extensa e de difícil visualização elaborei uma versão a partir da original com a reprodução e simplificação de algumas células -, mas a lógica permanece a mesma. As letras duplas são abreviações dos nomes dos colaboradores. A tabela pode ser lida assim: o colaborador Allan Vitor (alocado na coluna E) propôs uma redação alternativa (na célula 3E) ao texto original da minuta (redigido na célula 3A) e dois colaboradores (AR e AN) optaram pela sua versão, além dele próprio (AV). 
TABELA1. FERRAMENTA PARA CONSTRUÇÃO DE CONSENSO

\begin{tabular}{|c|c|c|c|c|c|c|c|c|c|c|c|}
\hline \multicolumn{4}{|c|}{ A } & B & \multicolumn{2}{|c|}{ C } & \multicolumn{2}{|c|}{ D } & \multicolumn{3}{|c|}{ E } \\
\hline \multicolumn{4}{|c|}{$\begin{array}{c}\text { FERRAMENTA PARA } \\
\text { CONSTRUÇÃO DE CONSENSO }\end{array}$} & \multirow[t]{2}{*}{$\begin{array}{l}\text { COLABORADO } \\
\text { RES } \rightarrow\end{array}$} & \multicolumn{2}{|c|}{ andremoura } & \multicolumn{2}{|c|}{ biancagomes } & \multicolumn{3}{|c|}{ allanvitor } \\
\hline Linha & \multicolumn{3}{|c|}{$\begin{array}{l}\text { MINUTA BASE - } \\
\text { enunciados e concordância }\end{array}$} & & AM & $\begin{array}{l}5 / J U N \\
12: 01\end{array}$ & BG & $\begin{array}{l}5 / \text { JUN } \\
13: 37\end{array}$ & AV & & \\
\hline 1 & $\begin{array}{l}\text { Seção II - } \\
\text { Dos Círculos }\end{array}$ & $\begin{array}{c}\% \\
\text { Nivel de } \\
\text { concord } \\
\text { ância }\end{array}$ & $\begin{array}{c}\text { Votos } \\
\downarrow\end{array}$ & Enunciado & \multicolumn{2}{|c|}{$\begin{array}{l}\text { Seção II - } \\
\text { Dos Círculos }\end{array}$} & \multicolumn{2}{|c|}{$\begin{array}{l}\text { Seção II - Dos } \\
\text { Círculos }\end{array}$} & \multicolumn{3}{|c|}{$\begin{array}{l}\text { Seção II - Dos } \\
\text { Círculos }\end{array}$} \\
\hline 2 & & $75 \%$ & 4 & $\begin{array}{c}\text { Concordância } \\
\rightarrow\end{array}$ & & & JO & & AV & AR & AN \\
\hline 3 & $\begin{array}{l}\text { Art. } \mathbf{2 7} \text { - Os } \\
\text { Círculos } \\
\text { constituem a } \\
\text { instância de } \\
\text { base da RAIZ, } \\
\text { podendo ser } \\
\text { organizadas } \\
\text { por no mínimo } \\
\text { três pessoas, } \\
\text { sendo pelo } \\
\text { menos uma } \\
\text { filiada em dia } \\
\text { com suas } \\
\text { contribuições } \\
\text { partidárias, } \\
\text { por afinidade } \\
\text { de lugar de } \\
\text { moradia, de } \\
\text { trabalho, de } \\
\text { estudo, } \\
\text { profissão, área } \\
\text { de atuação no } \\
\text { movimento } \\
\text { social, e outras } \\
\text { que forem } \\
\text { reconhecidas } \\
\text { pela Esfera } \\
\text { Nacional. }\end{array}$ & ${ }^{\circ} \mathrm{CS}$ & & Enunciado & \multicolumn{2}{|c|}{$\begin{array}{c}\text { Art. } \mathbf{2 7} \text { - "Os } \\
\text { Círculos } \\
\text { constituem a } \\
\text { instância de } \\
\text { fluxo entre a } \\
\text { RAIZ e os } \\
\text { movimentos } \\
\text { da sociedade, } \\
\text { podendo ser } \\
\text { organizadas } \\
\text { por no mínimo } \\
\text { três pessoas } \\
\text { filiadas, em dia } \\
\text { com suas } \\
\text { contribuiçōes } \\
\text { partidárias e } \\
\text { abertos à } \\
\text { participação } \\
\text { de } \\
\text { colaboradores } \\
\text { não filiados." }\end{array}$} & \multicolumn{2}{|c|}{$\begin{array}{c}\text { Art. } 27 \text { - Os } \\
\text { Círculos de } \\
\text { Cidadania } \\
\text { constituem a } \\
\text { instância de } \\
\text { base da RAIZ, } \\
\text { podendo ser } \\
\text { organizados por } \\
\text { no mínimo três } \\
\text { pessoas filiadas } \\
\text { que, em dia com } \\
\text { suas } \\
\text { contribuições } \\
\text { partidárias, } \\
\text { aglutinem-se } \\
\text { por afinidade de } \\
\text { lugar de } \\
\text { moradia, de } \\
\text { trabalho, de } \\
\text { estudo, área de } \\
\text { atuação nos } \\
\text { movimentos }\end{array}$} & \multicolumn{2}{|c|}{$\begin{array}{l}\text { Art. } 27 \text { - Os Círculos } \\
\text { constituem a instância } \\
\text { de fluxo entre a RAIZ e } \\
\text { os movimentos da } \\
\text { sociedade, podendo ser } \\
\text { organizadas por no } \\
\text { mínimo três pessoas } \\
\text { filiadas, em dia com suas } \\
\text { contribuições partidárias } \\
\text { e são abertos à } \\
\text { participação de } \\
\text { colaboradores não } \\
\text { filiados. } \\
\text { Parágrafo único: A } \\
\text { formação de Círculo com } \\
\text { menos de três pessoas } \\
\text { filiadas pode ser } \\
\text { autorizada mediante } \\
\text { deliberação do } \\
\text { respectivo Rizoma. }\end{array}$} & $\begin{array}{l}\text { ulos } \\
\text { ância } \\
\text { RAIZ e } \\
\text { da } \\
\text { do ser } \\
\text { r no } \\
\text { soas } \\
\text { m suas } \\
\text { idárias } \\
\text { à } \\
\text { de } \\
\text { não } \\
\text { lo com } \\
\text { ssoas } \\
\text { ser } \\
\text { ante } \\
\text { lo } \\
\text { ma. } \\
\text { rir a } \\
\text { xceção } \\
\text { no de } \\
\text { s para } \\
\text { orne } \\
\text { para a } \\
\text { culos } \\
\text { loguma de } \\
\text { veis } \\
\text { stação } \\
\text { le } \\
\text { l.. }\end{array}$ \\
\hline
\end{tabular}

Tabela 1. Ferramenta para construção de consenso. 
Partindo da coluna A, onde estavam dispostos os artigos do texto base, se um colaborador cadastrado na coluna D quisesse sugerir a alteração do artigo localizado na célula A3, ele deveria redigir a sua contribuição na coluna com seu nome, D3, e, caso outro colaborador discordasse da sua proposta ou quisesse apresentar uma outra contribuição alternativa para o mesmo texto, ele deveria escrever a sua contribuição na linha 3 da coluna que estivesse com o seu nome, como fez André Moura na célula 3C.

Não é preciso ir muito longe na análise do modo de funcionamento da tabela para constatar que essa proposta tendia a manter alguns dos problemas do Modelo Fórum relacionados, por exemplo, às dificuldades de redigir um documento com um número elevado de pessoas ou manter a coesão entre diferentes artigos do documento (a dificuldade de harmonizar o todo, como sublinhou Paulo Lima, acompanhado por Adolfo Senna). O que é importante ressaltar aqui é que a estrutura sincrônica e relativamente estanque do dispositivo fez com que as contribuições obedecessem a um princípio de ordem, evitando que fossem diluídas na contingência. Também praticamente eliminou as reivindicações por um processo participativo mais igualitário, o que é digno de nota. $\mathrm{O}$ agrupamento matricial permitiu que nenhuma intervenção fosse desprezada ou que se sobrepusesse às outras e as dissensões foram evidenciadas, de acordo com os princípios básicos do Consenso Progressivo. Bastaria deslizar o olhar por uma linha (item ou artigo do estatuto) da planilha que facilmente se localizaria uma manifestação de discordância: na tabela é possível ver que nenhum dos votantes optou pelo texto-base e três colaboradores apresentaram contribuições alternativas à versão do Allan Vitor, que obteve $75 \%$ de concordância. Apenas uma colaboradora, Joseane Oliveira (JO), optou por outra versão do artigo e seu alinhamento minoritário fica evidenciado na leitura da tabela. Por seu efeito aglutinador, esse modelo permitiu a comparação detalhada entre todas as propostas de redação para um dado texto, uma vez que contribuiu consideravelmente para eliminar o efeito dispersor da discussão linear. Além disso, esse método eliminou a necessidade de intervenção contínua de um sistematizador humano durante o processo, ao contrário do Fórum, onde se fez necessária a mediação constante de um sistematizador para tentar ordenar a distribuição dispersa das contribuições. A presença de um sistematizador em algumas situações foi vista, muitas vezes, com desconfiança na medida em que uma pessoa (ou poucas) tinha controle privilegiado sobre o processo podendo, na prática, selecionar, ignorar e transformar as diversas contribuições. Os próprios sistematizadores apontaram algumas vezes que a operação de sistematização muitas vezes inseria um componente personalista e antidemocrático no conjunto dessas práticas, como admitiu Alex, na construção do estatuto: 
Segue a sistematização da seção I do capítulo. Adotei como critério de seleção das propostas a minha opinião pessoal.

No Método de Planilhas, Alex atuou principalmente copiando os dissensos evidenciados no dispositivo para que fossem discutidos no Fórum de Discussão, havendo, assim, uma atuação complementar entre ambos as plataformas. Entretanto, como o próprio Alex indicou, boa parte do trabalho de sistematização já estava feito, já que o modo como estava configurado o sistema de tabelas fez como que ele funcionasse como um importante sistematizador não-humano. O Método de Planilhas alterou decisivamente o fazer coletivo: ao separar a redação dos itens do estatuto dos comentários (há apenas a sugestão para escreverem uma justificativa, no final) e do diálogo, diminuiu consideravelmente a magnitude das transformações do texto-base, reduzindo-as a mudanças pontuais e facilmente identificáveis. Por outro lado, o Modelo Fórum permitiu maior permeabilidade às contribuições, incluindo contribuições relacionadas a mudanças significativas na estrutura da organização. Algumas reclamações em relação ao uso das planilhas foram justamente por elas operarem essa separação e por ser difícil pensar a organização estatutária da Raiz separada dos seus princípios e conceitos fundadores. Houve também queixas em relação a um suposto efeito de exclusão do modelo, mas essas reclamações foram no sentido da dificuldade de adaptação ao seu funcionamento, pois a promoção da igualdade de participação era vista como uma grande virtude do método, ao contrário do Modelo Fórum, onde as várias reclamações dividiam-se entre queixas em relação à atuação do sistematizador (a exclusão injustificada de proposições dos debatedores ou mesmo a suposta promoção de propostas que teriam mais afinidade com o seu ponto de vista), à desconsideração de participações que ficavam esquecidas no meio de inúmeras outras e à influência demasiada das participações mais insistentes (que tinham mais presença em número e, portanto, maior visibilidade). A dificuldade na operação do Método de Planilhas também se deveu, em alguns poucos casos, ao uso de dispositivos portáteis (smartphone e tablet), que tornou a manipulação de planilhas extensas uma tarefa complicada e que requeria bastante paciência, sobretudo por não estarem acostumados com a lógica deste formato ${ }^{23}$. Se, para alguns, trabalhar com planilhas era como brincar com um joguinho de vídeo-game, para outros, era muito difícil olhar em caixinhas muito segmentadas e isso não é nada trivial quando se tem como objetivo político aumentar as possibilidades de participação. Essa dificuldade também diz respeito diretamente à descrição antropológica que agora vê diante de si novos entes analíticos cuja feição

23 Essa familiaridade com a lógica do modelo de planilhas também acompanhava, de certo modo, a faixa etária daqueles que o utilizavam, de modo que o formato foi mais bem acolhido pelos mais jovens. 
desafia a hermenêutica hegemônica na disciplina, pouco afeita a esse tipo de configuração geométrica.

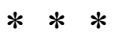

Outra questão que emergiu da análise das práticas políticas nos ambientes digitais foi a existência de diferentes regimes de temporalidade que pareciam ter incidência direta sobre essas práticas e que se articulavam de diversas formas, às vezes de modo explicitamente conflituoso. No espaço do Fórum, a discussão a respeito do travessão no nome da Raiz não pertencia ao mesmo modo de existência temporal de um debate presencial. Portanto, a surpresa com o fato de uma discussão tão pontual chegar ao quinto dia só faz sentido se considerarmos um regime temporal que é exterior à temporalidade da plataforma. Nesse caso, o Fórum teve o efeito de comprimir o tempo e ele o fazia na medida em que era um espaço com características muito específicas. As inúmeras contribuições, provenientes de diferentes momentos e lugares, eram reunidas em um mesmo ambiente, plano e contínuo, cuja linha temporal era facilmente deslocada com o deslizar da página para cima e para baixo. Embora houvesse marcadores temporais (data e horário) nas manifestações dos agentes, eles pareciam ter pouco efeito sobre essa temporalidade do dispositivo. $\mathrm{O}$ senso de passagem do tempo parecia ser fortemente marcado pelo caráter cumulativo do dispositivo (empilhamento linear de mensagens), por sua configuração estético-estrutural e pelo número de participantes e mensagens postadas. Assim, um número excessivamente grande de mensagens tornava muito difícil o que os cidadanistas chamavam de acúmulo de discussão e, por isso, concorria para uma noção de um tempo finito, função do próprio esgotamento da discussão (não havia mais o que dizer ou a conversa se dirigia a tantas direções que ficava difícil estabelecer alguma linha de continuidade, como se ela tivesse terminado naturalmente); ou para uma noção de repetição, o eterno retorno que parecia levar a discussão ao infinito. Aqui chama a atenção o fato de que o Fórum, embora estivesse fortemente calcado na lógica de fluxo diacrônico, também permitia, em alguma medida, a reversibilidade, isto é, a retomada e a interação com o que tinham discutido em um ponto anterior do tempo. A acumulação, que parece ser uma vantagem da escrita sobre a oralidade, se mostrava um problema onipresente nessas assembleias digitais e, tudo leva a crer, que o esquecimento também cumpria um papel fundamental ao minorar os seus efeitos adversos. Embora, em princípio, o digital permitisse recuperar qualquer participação dentro de uma conversa, era comum que muitas questões e ideias propostas pelos participantes fossem ignoradas, como 
mencionado antes, o que, apesar de gerar manifestações de descontentamento, contribuía para que o debate não se prolongasse em demasia e para manter o foco no principal assunto em exame.

As formas de temporalidade do espaço Fórum, obviamente não operavam no vácuo e estavam constantemente se articulando com diversas agências e modos de temporalidade específicos. O debate sobre o conteúdo do capítulo I do estatuto foi marcado por muitas reclamações em relação à celeridade dos trabalhos, como protestou Felipe Senna:

Aqui, porém, já se torna inevitável retornar a outra divergência de fundo que procurei expressar todas as vezes em que senti necessidade de fazê-lo: você e muitos outros dos que estão à frente do processo partem do princípio de que "não há tempo a perder"; eu parto do princípio de que a oportunidade de se construir um partido realmente diferente no cenário nacional não merece ser contagiada por qualquer elemento de pressa.

A tentativa de imprimir um ritmo mais acelerado à escrita do primeiro capítulo parecia ir de encontro ao regime temporal promovido pela plataforma, bem como à dinâmica do próprio Consenso Progressivo. Vale a pena chamar a atenção para o fato de que a forma de existência temporal do Consenso Progressivo pressupunha um tempo endógeno que fosse gerado e expandido a partir do desenvolvimento do processo argumentativo. Por isso a ideia de que não chegaram ao consenso em relação a algumas questões e que elas deveriam ser remetidas à votação também poderia indicar a submissão do consenso e da sua temporalidade intrínseca a uma temporalidade que lhe seria exterior, como aquela característica do período eleitoral que será discutida no próximo capítulo.

Mas se a pressa era um indicativo do constrangimento da temporalidade da plataforma e do consenso a um regime temporal exógeno, não havia a necessidade de recorrer, como fizeram alguns cidadanistas, a explicações que supunham finalidades escusas por trás do interesse daqueles que pediam mais celeridade às discussões. O que parecia haver era, antes de tudo, a existência de um regime temporal gerencial, uma temporalidade marcada por prazos, mesmo não havendo um evento (como uma eleição) que servisse como referência temporal limite. A construção do estatuto mostrou um modo possível de operação desse regime: em primeiro lugar havia a divisão de uma tarefa em etapas e, a partir da estimativa do tempo necessário para a realização de uma das etapas da tarefa, foram estabelecidos prazos para consecução de cada uma das etapas. É digno de nota que, nesse processo, houve a equiparação entre os intervalos de tempo (que eram homogêneos) e as etapas do estatuto (cada uma com sua própria medida interna), equiparação cuja inconsistência sempre vinha 
à tona nas contínuas alterações dos prazos para término dos trabalhos e pelos atropelos na construção de convergências, o timming afobado de Alex:

Opa gente, chegando agora. Reforço a minha opinião que está havendo muita pressa...mal saiu a deliberação pela discussão por capítulos, o pessoal ainda está chegando, não existe ainda nenhum círculo formatado e já venceu o prazo de contribuição?? Quantas pessoas viram essa discussão aqui? Mas tudo bem, vou tentar atender esse timming afobado. Acho que ao menos o documento sistematizado proposto pelo@andrenoronha deveria ser postado no grupo do Face para publicidade geral e como forma de chamar àqueles que tem questionamentos ou sugestões para participar aqui.

Felipe Senna, sempre muito enfático, reconheceu explicitamente a contradição entre a celeridade para o cumprimento dos prazos e o princípio do Consenso Progressivo:

Outra coisa é essa pressa desmedida, contra a qual vários aqui já se posicionaram. Colocar o próximo capítulo ainda hoje à noite, sem que tenhamos clareza sobre como superaremos as divergências? Por quê? Para quê? Proponho, em vez disso, que nos esforcemos todos para fechar a discussão deste Capítulo de modo exemplar, para que sigamos adiante tendo como referência o que aqui se fez.

O modelo de tabelas, embora mostrasse relativa simplicidade em virtude de sua estrutura visivelmente sincrônica, parecia promover uma forma de existência temporal nem um pouco trivial. A princípio o modelo matricial levava ao extremo a ideia de reversibilidade, de modo que qualquer participante poderia, idealmente, começar a partir de qualquer ponto da tabela, ir e voltar, sem grande prejuízo em sua atuação. Além disso, mesmo o seu voto poderia ser feito, apagado e refeito, de acordo com a versão do texto que julgasse melhor, não sendo necessariamente aquela de sua própria autoria. Aqui é importante abrir um parêntese, pois havia um deslocamento em relação ao que seria o ideal do Consenso Progressivo, que recomenda o voto apenas em torno de pontos não consensuados ao final do processo (e só em último caso). Já na planilha era possível votar a todo momento, mas, devido ao fato do voto ser dinâmico e do Método de Planilha incentivar a proliferação de células com alterações mínimas (a diferença entre duas versões pode ser apenas de uma palavra), não havia o efeito divisor que existia no modelo de votação única entre poucas categorias. Esse ponto é importante, pois alerta para o perigo de generalizações apressadas e mostra que alterações sutis no funcionamento do voto podem ter efeitos radicalmente distintos. 
Ao olhar o ambiente matricial mais de perto, é possível discernir elementos que de certo modo traem a reversibilidade tão característica do sistema. $\mathrm{O}$ acúmulo de variações do texto-base tornava mais difícil a avaliação de cada versão e a escrita de uma nova, tanto pela quantidade de informação a ser comparada, quanto pela extensão da planilha - que impossibilitava visualizar muitas contribuições ao mesmo tempo -, o que dificultava uma comparação minuciosa. É como se o processo criativo tivesse chegado ao seu ponto de saturação, o que convidava o agente a passar para o próximo tópico e dar o assunto por encerrado. Embora isso ocorresse em um grau muito menor do que no Modelo Fórum, o seu efeito na constituição da ideia de uma tarefa terminada não pode ser desprezado. Além disso, suponho que o tipo de documento em construção também favorecia, em parte, o surgimento de um senso de um tempo cumulativo que corria em uma única direção (embora houvesse elementos que também apontassem para uma dinâmica sincrônica), tornando menos atraente a possibilidade de retorno. O estatuto possuía, ao mesmo tempo, uma progressão (lógica, conceitual e de conteúdo) e interdependência (entre alguns capítulos e seções), que tornava qualquer mudança de parte do texto um exercício bastante delicado, já que a alteração ou retirada de um conceito ou uma ideia poderia exigir a reconfiguração de seções anteriores ou posteriores.

Ainda que o Modelo Fórum e o Modelo de Planilhas fossem utilizados para um mesmo objetivo geral, é preciso chamar a atenção para o fato de que esses dois ambientes apontavam para estatutos bastante diferentes - e que resultariam, muito provavelmente, em distintas formas de organização da Raiz. Fica evidente que questões de método e plataforma são, em sua essência, questões políticas e dizem respeito diretamente a questões de horizontalidade, hierarquia, consenso, transparência, abertura ao outro, cristalização de formas etc. Embora essas duas plataformas compartilhassem características ligadas a sua natureza lógica e abstrata, pode-se também perceber que os efeitos dessas propriedades da digitalidade não são tão simples quanto possam parecer e que os dispositivos podem funcionar de formas bastante distintas, o que aponta para a necessidade de estudos etnográficos mais aprofundados que tenham como objeto essas tecnologias em operação. Por ora, minha incursão etnográfica foi limitada a apenas alguns casos pontuais, embora acredito já ter sido suficiente para mostrar que o digital pode funcionar como uma tecnologia instauradora, conformadora e normativa e que pode gerar efeitos imprevisíveis, inclusive o de (des)potencializar futuros alternativos. 


\subsection{Novas tecnologias, velhos dilemas}

Já é praticamente consenso entre os cientistas sociais que a democracia está sendo radicalmente transformada pela incorporação das novas tecnologias digitais nas práticas políticas dos sujeitos. Entretanto, a maior parte das análises recentes dos levantes populares dos últimos anos tende a ver o digital apenas como uma ferramenta neutra que permitiria incrementar as possibilidades de participação e aumentar e descentralizar os fluxos de informação - embora a balança tenha começado a pender para o outro lado como, por exemplo, na discussão acerca do papel dos algoritmos na constituição de bolhas de informação. O que fica claro, com base no que até agora foi exposto, é que o digital pode atuar decisivamente na configuração dessas práticas e, inclusive, na transformação dos significados da política e da democracia. O digital representou para muitas formas de atuação política que emergiram neste século a eliminação de barreiras que impediriam a realização dos sonhos de democracia direta e a democracia representativa está passando a figurar cada vez mais como uma instituição ultrapassada que deve ser radicalmente transformada.

A formação da Raiz foi bastante marcada pela visão de que as novas tecnologias possibilitariam a realização da democracia na sua forma mais plena, em que todos teriam a possibilidade de participar ativamente das decisões. Não é difícil perceber que a inclusividade, propiciada pela plataforma digital, encontrava-se no centro da definição de democracia do coletivo, mas a coisa parece um pouco mais complicada. Em algumas ocasiões a inclusividade era relacionada à inclusão social em geral, da qual também faria parte o acesso às novas tecnologias; em outras, ao conhecimento técnico para manipulá-las; mas, na prática, a inclusividade tinha a ver, sobretudo, com a possibilidade de participação (assim, todos os que possuíssem computadores e fossem letrados digitalmente estariam incluídos) e não com a participação de fato. Assim se pode entender como, em muitos casos, algumas decisões importantes tomadas por quatro ou cinco pessoas, tenham sido consideradas tão legítimas quanto decisões tomadas por vinte ou trinta membros do coletivo. ${ }^{24} \mathrm{~A}$ baixa participação em alguns debates e deliberações até era vista como um problema, mas não a ponto de colocar em risco sua noção de inclusividade e de democracia, afinal de contas, era uma escolha não participar. Não há dúvidas de que essa concepção (de que a

24 Houve também reclamações em relação a decisões tomadas em deliberações com poucos participantes. Entretanto, essas queixas ocorreram em pouquíssimas ocasiões e as críticas eram dirigidas, principalmente, à falta de divulgação das votações. 
participação é função de um ato de vontade deliberada do sujeito) é tributária da imagem moderna do indivíduo racional dotado de vontades e interesses que podem ser buscados após um cálculo de custos e vantagens.

Mas para que a inclusividade fosse efetiva, os cidadanistas reconheciam reiteradamente a necessidade de que todas as ações fossem pautadas pela transparência, já que, para participar, era preciso saber o que estava acontecendo, como se estava decidindo etc. No entanto, as conversas apontavam para uma indefinição em relação à ideia de transparência que me parece decisiva. Normalmente, bastaria manterem o tópico em discussão ativo no Loomio por alguns dias, antes da tomada de decisão, para a ação ser considerada como pautada pela transparência, afinal de contas, estava lá para todo mundo ver. No entanto, era muito frequente a reclamação de que não se sabia onde e quando um determinado assunto teria sido conversado ou uma dada decisão teria sido tomada. A pulverização das discussões nas reuniões presenciais, grupos de trabalho, WhatsApp, Facebook, Loomio e Telegram (em menor grau) era, em grande parte, causa dessa fragmentação excessiva da informação, o que contribuiu para a formação de uma noção de transparência mais ativa, ligada à preocupação com a publicização intensiva das ações e discussões que estavam sendo travadas, sobretudo, no Loomio. Por outro lado, essa fragmentação também reforçou a ideia de que a desordem seria inerente à democracia direta e aos processos horizontais (como vimos em relação ao Fórum de Discussão) e de que era preciso uma agência para colocar ordem no caos. É bom ressaltar que esse senso de desordem variava de acordo com cada espaço considerado: em linha ascendente havia as reuniões presenciais, seguidas do ambiente de planilhas, do Loomio e do Facebook (para a maioria a própria imagem do caos quando se tratava de construção coletiva). A reflexão de David Ribas resumiu muito bem essa concepção e convergiu em vários pontos com o sentimento predominante:

Boa tarde@joaogomes estamos desorganizados sim. Basta acompanhar o Loomio para constatar. O excesso de descentralização está tornando inviável qualquer tipo de movimento. Não adianta abrir diversos canais de comunicação, quando tudo fica/cai no limbo do Loomio, Facebook etc. Chegamos ao ponto de muitas pessoas não terem mais um interesse ativo em acompanhar a RAIZ, e digo daqueles que já estão envolvidos a algum tempo, porque as informações são desencontradas, não agregam, ou não sai do lugar, devido ao excesso de fragmentação (...). A RAIZ enquanto movimento está sem norte. A direção (ou nome que melhor preferir) é que delimita esse norte, e isso não significa a perda da horizontalidade. Lembro novamente que somos um corpo (cabeça, tronco e membros). A cabeça não está funcionando. Não por culpa de uma pessoa. Mas por ingerência de todos os envolvidos, tudo é disperso; fragmentar é sair de um limbo e cair no buraco negro. 
A mensagem de Ribas foi explícita quanto à necessidade de uma direção para impor ordem à fragmentação gerada pela ingerência de todos nos espaços digitais, mas também chamou a atenção para os diferentes sentidos que a horizontalidade assumia no interior do coletivo. Como vimos, um dos atributos definidores da horizontalidade era a possibilidade de participação de todos nos processos de decisão, o que ia ao encontro da visão de Ribas. Mas ele apontou para certa tendência, presente no coletivo, que via a existência de mecanismos de controle e direção como plenamente conciliáveis com a ideia de horizontalidade ou mesmo a condição de sua existência. Essa tendência se chocava com outra, mais presente no começo do movimento, de que a horizontalidade não poderia comportar qualquer direcionamento que não fosse expressamente deliberado nas assembleias presenciais ou digitais. Mas a ideia mais prevalecente era a de que esses elementos ordenadores fossem, por sua natureza, contrários a ideia de horizontalidade, embora fossem necessários para sua existência, por conterem as forças que levariam à fragmentação e à entropia.

Ao observar com atenção essas discussões é fácil perceber que na base dessa diferença de perspectivas havia indefinições e disputas acerca do que poderia ser a horizontalidade e a verticalidade (ou hierarquia). Periodicamente ressurgia o debate e as opiniões se dividiam em torno da questão sobre se funções ou instâncias de coordenação, organização e execução constituíam uma intrusão hierárquica no horizontalismo defendido pelo coletivo.

Concordo em quase tudo. Apenas discordo que chamar a coordenadoria seja necessariamente ranço de hierarquia. Acho que coordenadorias são criadas exatamente para ajudar na coordenação. Quando existem muitos membros propondo vários posts que no fundo podem trazer a uma mesma discussão uma coordenação pode ser útil e a coordenadoria a se pronunciar é a que tiver maior relação com o assunto. Isso não quer dizer que ela irá decidir, muito pelo contrário. Irá encaminhar para a horizontalidade.

A postagem de Mateus Pomar acompanhou as opiniões que defendiam o papel mediador das coordenadorias para o encaminhamento das discussões e propostas de ações à discussão aberta. Nessa visão, a organização de um debate ou planejamento de uma ação não possuiria um viés autoritário se as coordenadorias não usurpassem a função deliberativa do coletivo. Mas longe de representar a opinião da maioria, essa concepção mostrava uma divergência de origem que sempre permeou os modos de pensar a horizontalidade da Raiz e que foi muito bem colocada na postagem de Daiane Alves: 
@ danielvieira eu entendo sua visão, mas discordo. Trazemos bagagens e visões diferentes e nosso entendimento sobre organização e horizontalidade não é o mesmo. O que você considera organizador, pra mim, é centralizador. Pra mim, ao estipular que reuniões pra falar da RAiZ devam necessariamente passar pelo GT de Articulação ou que comunicados só poderão ser elaborados passando pelo GT de Comunicação, estamos perdendo horizontalidade. Os GTs acabam se tornando hierarquicamente superiores, como algo regulador ou controlador. Sei que essa não é sua visão e que você interpreta de outra maneira, mas é assim que eu vejo.

Ao contrário de Mateus Pomar e Diogo Vieira, para quem as Coordenadorias e os Grupos de Trabalho apenas organizavam os trabalhos, sem necessariamente promover a formação de hierarquias, Daiane acreditava que a função mediadora dessas instâncias especializadas colocava em risco a horizontalidade do coletivo. A atuação dos Grupos de Trabalho, das Comissões e das Coordenadorias foi nesse momento formativo da Raiz objeto de muita desconfiança e suscitou inúmeros desentendimentos, sobretudo em relação às ações do setor de comunicação, como vimos no capítulo 1. Em primeiro lugar, quase todo cidadanista se via, de certa forma, como um agente de comunicação e fazia questão de utilizar os meios de que dispunha para chamar as pessoas e promover as ideias do coletivo, principalmente nos espaços digitais. Por isso a ideia de Diogo (de que fazer memes e ficar lançando sem passar pelo GT Comunicação é estranho), soava absurda para muitos de seus companheiros. Um caso semelhante poderia ser a iniciativa de qualquer integrante do coletivo para firmar uma parceria com uma instituição que poderia somar esforços com a Raiz em prol de alguma causa. ${ }^{25}$ Seria impensável, para a maioria, que todas as parcerias do tipo tivessem que passar pelo Gt de Articulação Política para começarem a ser negociadas. As discussões sobre essas situações-tipo faziam com que as críticas aos Gt's fossem de fácil compreensão e tendiam a angariar amplo apoio, uma vez que essas atividades eram entendidas como eminentemente políticas; mas em atividades que pareciam mais técnicas (a despeito de movimentos no sentido da diluição da fronteira entre política e técnica), as críticas aos grupos especializados e coordenadorias se tornavam mais difíceis e cercadas de controvérsias. Para os defensores dos Gt's o caos só poderia ser evitado por algum agente organizador, já que as coisas abandonadas a si mesmas tenderiam naturalmente à bagunça. Por isso, para esses sujeitos, tais agentes externos eram garantidores da horizontalidade que, sem eles, provavelmente se tornaria um fim em si, na melhor das hipóteses, paralisador, na pior, desagregador e dissociativo. Os críticos dos Gt's obtinham algum sucesso em convencer seus interlocutores que havia sim, nesses espaços, a

25 Esse caso hipotético foi sugerido por um dos cidadanistas, mas, na prática, sempre foi comum que eles se aproximassem de outros coletivos por iniciativa própria e como representantes da Raiz. 
tendência para tomarem decisões autocráticas, sem a deliberação na Teia, e tinham a favor dos seus argumentos os casos empíricos que costumavam ser muito convincentes.

Vale dizer que muitas controvérsias políticas formuladas em termos abstratos e de difícil resolução, muitas vezes caminhavam para a solução quando remetidas a casos concretos, que tinham a capacidade de deslocar decisivamente certas posições. A própria ideia de que o GT não deliberava, mas apenas planejava, organizava e executava, dificilmente se sustentava quando viam que, na prática, qualquer processo de organização e planejamento requeria uma cascata de pequenas decisões que, muitas vezes, tinham efeitos notáveis sobre todo o processo político. Entretanto, ainda persistia um problema: se num primeiro momento pareceria plausível remeter todas as decisões à Teia (o digital traria essa possibilidade), a prática mostrava que essa era uma possibilidade de difícil realização. Então a questão que se colocavam era: como seria possível garantir a horizontalidade sem que todos tivessem que decidir sobre tudo a todo instante? É importante mencionar o fato de que os críticos dos Gt's muitas vezes também viam, nas grandes dificuldades de implementação da democracia direta radical, uma indicação de sua tendência natural à desordem. Mas se a abertura à participação de todos nos processos decisórios constituía a realização mais plena e concreta da horizontalidade, a própria noção de horizontalidade se tornaria uma ideia irrealizável em vista dessa impossibilidade prática de todos poderem participar de todas as decisões.

Não é difícil perceber que no fundo dessa problemática persistia uma obsessão com o controle, pois se um lado afirmava que os Gt's precisavam controlar alguns processos para evitar a fragmentação e a desordem, o outro dizia que se todos não controlassem tudo, os Gt's tenderiam a se tornar instâncias hierárquicas e autoritárias e permeáveis a uma miríade de interesses personalistas. O que mais uma vez remete à ideia de que as ações do coletivo, deixadas a si, tenderiam naturalmente à desordem e só a ação consciente e deliberada de controle poderia evitar essas forças desagregadoras. O equacionamento frequente da organização com o controle e da ausência de agências controladoras com a desorganização impôs um desafio para pensarem a realização de ações autônomas, tão caras aos modos de pensar a política do coletivo. Como seria possível os sujeitos criarem e tomarem iniciativas sem terem que passar o tempo todo pelo crivo, seja de instâncias especializadas, seja da grande assembleia geral digital? Para complicar a questão, não era incomum a reclamação de que as ações dos grupos especializados interferiam negativamente na igualdade de participação, na medida em que iniciativas mais alinhadas às preferências dos membros dessas instâncias teriam maior possibilidade de serem efetivadas e de sofrerem menor alteração em relação à proposta original. 
Os impasses que permeavam as relações entre governança, autonomia, participação e horizontalidade manifestavam-se muitas vezes por meio de acusações, insinuações e atribuição de intenções antidemocráticas a algum(s) dos agentes envolvidos nas situações discursivas. Essas situações de conflito desvelavam o espectro da desconfiança que assombrava essas relações e acionavam discursos que reivindicavam a prática do Ubuntu e o estabelecimento de vínculos de confiança como condição para solucionar ou ao menos garantir que esses impasses não colocassem em risco a existência do coletivo.

O "eu sou porque nós somos" é muito profundo, significa que a nossa humanidade só se realiza na humanidade do outro. Não é um conceito piegas, ou um ser "bonzinho" ou pacifista, ou de negação das contradições, ao contrário. Mas pressupõe companheirismo, camaradagem, confiança (sobre confiança daria para abrir um capítulo a parte, porque ao longo destes dois anos o que tem grassado é a desconfiança e desconstrução do "outro" a todo instante). Como realizar um projeto coletivo sem confiança? Ou sempre apontando o dedo para os outros (inclusive para dizer que falta atuação em movimentos, sendo que normalmente quem cobra isto é quem não está nos movimentos, nem na semeadura cotidiana de um círculo).

Como exposto no capítulo 1, a desconfiança atuava decisivamente na conformação do coletivo e pode ser explicada, em parte, em razão da trajetória pregressa desses sujeitos na política, no mais das vezes, marcada por uma série de frustrações, como destacavam reiteradamente os cidadanistas egressos da Rede. Havia também a influência da fragmentação dessas relações entre as plataformas digitais e mesmo no interior de uma mesma plataforma e isso não pode ser desprezado. Do mesmo modo que era difícil rastrear todo o percurso enunciativo que levava a uma decisão importante, havia a possibilidade de retomar a memória desse processo, mas de forma extremamente fragmentária, o que poderia ser mais pernicioso do que não haver registro algum. Assim se tornava possível, por exemplo, apontar as contradições nos discursos dos companheiros (contradições que às vezes eram consequência direta do efeito fragmentador da plataforma) ou mostrar que determinadas decisões eram autoritárias, pois elas passavam por cima de decisões tomadas anteriormente naquele espaço ou em outro, algo que não era raro acontecer. Havia quase um consenso de que os efeitos desagregadores e paralisantes da desconfiança impossibilitavam a 
construção política coletiva, levando muitas vezes ao horizontalismo paranoico a que Pedro se referiu no capítulo anterior, ou seja, ao temor quase obsessivo de que alguém estivesse prestes a manipular o processo decisório. De papel secundário e acessório a confiança passou então a figurar como uma das condições fundamentais da existência da forma política do coletivo. Era preciso confiar nos grupos especializados para que pudessem atuar sem terem que remeter todas as suas decisões à assembleia, assim como era impossível assegurar a autonomia e o protagonismo dos agentes sem que houvesse confiança na honestidade de suas intenções. E essa questão sobre a necessidade de confiar também remetia à tensão inerente à ideia de representação ou de delegação de poder a um representante. Pois por mais que fosse objeto de desconfiança (e até de desprezo), a figura da liderança e do representante político não poderia ser simplesmente descartada, já que se tratava de um coletivo que se organizava para atuar no campo político-institucional, seja direta (lançando candidatura própria), seja indiretamente (apoiando candidaturas de outros partidos). A questão passava a ser cada vez mais sobre as condições de possibilidade de se confiar em alguém, uma vez que nunca deixavam de chamar a atenção para os efeitos nefastos que ações delegadas mal-pensadas ou mal-intencionadas poderiam provocar. Para diminuir esses riscos a transparência mais uma vez assumia um papel decisivo ao permitir que todos pudessem saber o que estava se passando e participar e intervir nas práticas sempre que necessário.

De certo modo a transparência, por si mesma, poderia gerar confiança e aqueles empenhados em publicizar as ações da Raiz no Loomio e aumentar o número de participantes nos fóruns decisórios eram, frequentemente, reconhecidos por sua postura, percebida como profundamente democrática. Ademais, a confiança também dependia da possibilidade de obstaculizar e rever as decisões, algo que estava muito enraizado no modo de agir dos cidadanistas, bastante marcado pela experimentação. $\mathrm{O}$ digital era essencial nesse sentido na medida em que, não apenas estimulava $\mathrm{e}$ imprimia formas às experimentações criativas dos cidadanistas, como permitia a interrupção rápida de qualquer ação que atentasse contra os princípios da Raiz. Mas restava ainda um problema cuja solução talvez não fosse tão simples. Se muitos reconheciam as virtudes políticas da confiança, ela não parecia ser simplesmente resultado de um ato de vontade deliberado, como sugeriu Diego Veiga, ela não surgiria como um passe de mágica:

Somente pedir confiança para as pessoas, para mim não ajuda em nada. Não se pode exigir confiança sem se conhecer. E só se conhece com o tempo. Isso é um processo lindo, mas trabalhoso. Não mágico e automático. 
A ideia de que relações de confiança dependeriam da aproximação das pessoas, do estabelecimento de relacionamentos interpessoais, tinha muita força na Raiz e fazia com que o digital fosse visto com reservas, na medida em que dificultaria a constituição desses vínculos ou até teria o efeito oposto. Por isso as reuniões presenciais eram tão valorizadas a ponto serem realizadas no formato de imersão cuja proposta era justamente incentivar as relações de afeto e promover os laços interpessoais - ao contrário, por exemplo, da plenária que, mesmo sendo presencial, seria um formato muito mais frio. Havia, sem dúvida, um tanto de exagero nessa tendência em conceber o digital como frio e destituído de afetos positivos, pois bastaria um olhar mais acurado para as conversas do Loomio para ver que nelas se constituíam muitas relações de admiração, afeto e camaradagem, sobretudo quando as interações se davam no âmbito de um esforço colaborativo para a consecução de alguma tarefa. Esses momentos de trabalho colaborativo online eram muitas vezes marcados pela valorização da doação de si, isto é, o reconhecimento da dedicação daqueles que se empenhavam em tarefas de grande importância para o coletivo, de modo que passavam a gozar de grande prestígio entre os que acompanhavam ou se dedicavam às mesmas atividades. Atitudes de desprendimento e generosidade também costumavam ser um convite ao estabelecimento de vínculos mais sólidos, principalmente quando elas ocorriam em situações de muita disputa nas quais os ânimos se mostravam acirrados. Mas para que se constituíssem laços entre os sujeitos era necessário que suas interações fossem contínuas, que frequentassem os mesmos tópicos em discussão, o que muitas vezes se tornava difícil em vista da grande quantidade de assuntos em debate nos diferentes espaços. Por residirem em estados e cidades diferentes, muitos membros da Raiz se conheciam apenas no âmbito da plataforma digital e em alguns casos as reuniões presenciais, como as Teias Nacionais, se tornavam oportunidades para grandes encontros entre camaradas que construíram vínculos afetivos, mas que nunca tiveram oportunidade de estabelecer relações face a face, algo fácil de constatar em comentários antes e após os encontros. Isso indica que a concepção do outro e o estatuto dos vínculos nos meios digitais não podem ser reduzidos meramente à identificação de uma lista de atributos ou a uma rede que os define, os particulariza e os constitui de acordo com parâmetros como modalidade e quantidade de conexões.

Os encontros presenciais eram considerados eventos políticos no seu sentido mais amplo, pois eram vistos como momentos que atualizavam, reafirmavam e revigoravam o senso de coletivo, o companheirismo e os afetos; contribuíam para imprimir uma forma característica ao movimento; davam o estímulo necessário para prosseguir nas lutas e na construção da Raiz; e se tornavam momentos especiais de abertura e renovação de práticas e ideias. Era muito comum a atribuição de 
certo esmorecimento do coletivo à baixa frequência de encontros presenciais, juízo que recebeu uma elaboração muito profunda na reflexão de Cláudio Martins:

(...) ao menos quem defendeu o cancelamento daquela [Teia de Fortaleza] poderia propor um novo encontro, ou vamos seguir somente no virtual e na comodidade de nossos sofás? Os encontros presenciais são muito importantes, nada pode substituí-los, assim como nada substitui a luta ombro a ombro, isso porque os vínculos se tornam mais fortes e a coragem aflora com verdade (sem o anteparo de um computador). Daí penso que devemos buscar compreender melhor o sentido do afeto, da potência, dos desejos, do amor (sim do amor), da fraternidade, do companheirismo, da colaboração (e não da competição ou da contínua desconstrução) como categorias políticas.

Havia uma visão muito bem aceita de que o descontentamento de vários cidadanistas não teria resultado em saídas se houvesse uma rotina mais regular de encontros. É como se o presencial fosse o antídoto para o sentimento de desgaste provocado ou amplificado pelas forças desagregadoras inerentes à distância física e à digitalidade. O desligamento do coletivo também era facilitado quando o vínculo existia somente nos ambientes digitais, podendo efetivar-se de forma silenciosa, quase imperceptível. Aqueles que participavam com frequência dos debates normalmente criavam um tópico de discussão para anunciar a saída e expor as suas motivações, mas em quase todas as ocasiões não havia muitos apelos para que a decisão fosse revertida, na verdade, o que havia geralmente, eram manifestações de pesar pela decisão e até a concordância com as motivações alegadas para a desistência. $\mathrm{O}$ ambiente pouco amistoso dos debates online e a sensação de que havia muitas discussões no Loomio e poucas ações efetivas estavam entre as principais razões alegadas para o afastamento da Raiz. As críticas à falta de atuação da Raiz muitas vezes vinham acompanhadas de comentários que sugeriam uma falta de clareza em relação à atuação do movimento, algo que constatei repetidas vezes. A Raiz não assumia como objetivo primário a criação de um movimento social que atuasse nas diferentes áreas de preocupação e engajamento de seus membros, finalidade que, por vezes, alguns reclamantes atribuíam-lhe. A proposta era que os membros da Raiz atuassem nos movimentos e causas sociais já existentes podendo, a partir daí, gerar ações internas -, tendo a Raiz como retaguarda e como espaço político mais abrangente que assimilasse essa atuação no conjunto de um programa político mais amplo. Deste modo, boa parte dos membros da Raiz estava engajada em outros movimentos e trazia a sua experiência desses movimentos para pensar a política dentro das respectivas áreas - sem estarem impedidos de participar dos Círculos temáticos de outras áreas. O que parece ter ocorrido foi que 
inúmeras pessoas se vincularam à Raiz sem se engajarem ativamente em quaisquer causas, mas alimentando a expectativa de que logo surgiriam ações organizadas de militância ou intervenção, algo que praticamente não ocorreu. O fato de esse vínculo ter começado na plataforma digital pode ter sido decisivo para esse sentimento de frustração uma vez que o Loomio induzia, naturalmente, à sensação de pertencimento e de presença constante no cotidiano da Raiz, a ponto de ser visto, muitas vezes, como uma espécie de duplo digital do coletivo, como se ali estivesse toda a Raiz. Mas o motivo de saída mais presente na alegação dos egressos do movimento era, sem dúvida, a centralização do processo decisório nas mãos de poucas pessoas ou pequenos núcleos, tendência vista como autoritária e manifestamente oposta aos princípios que alicerçavam a construção da Raiz. Era justamente esse o teor de um trecho de uma carta aberta publicada no Loomio, no início de 2017, anunciando a saída de sete integrantes do movimento:

E aqui consideramos o principal fato de nossa decisão coletiva de rompimento com a RAIZ: a quebra de confiança e a evidente deturpação dos princípios acordados e respaldados na "Carta Cidadanista" por práticas que direta e indiretamente que constroem "super pessoas", hierarquicamente superiores de fato, completamente deslocadas de uma organização horizontal. Se construir uma organização horizontal é um dos pilares de reivindicação de parte significativa das pessoas que se aproximam da RAiZ, qual o sentido permanecer nela se isto não acontece de fato?

Sem querer entrar no mérito da manifestação dos agentes, o que me parece bastante significativo é que os comentários sobre focos de centralismo hierárquico na maioria das vezes eram feitos em termos genéricos (decisões tomadas entre amigos, em reuniões excludentes etc.) e vinham acompanhados de queixas em relação à falta de transparência. É razoável supor que isso se deva, em alguma medida, às dificuldades de acompanharem as minúcias do processo decisório e às desconfianças já mencionadas. Também é de se esperar que a pulverização das deliberações por diferentes espaços favorece aqueles que acompanhavam e participavam mais ativamente dessas discussões, na medida em que detinham maior conhecimento (tanto dos assuntos em discussão quanto da própria dinâmica da deliberação) e, portanto, maior influência sobre as decisões tomadas, principalmente aqueles que participavam com mais frequência das reuniões presenciais, encontros onde sempre foram decididas questões de grande importância. Há casos muito instrutivos de cidadanistas questionarem resoluções por terem sido supostamente decididas autocraticamente e de serem imediatamente informados sobre os encontros onde essas questões foram discutidas e deliberadas. De todo modo, raramente os integrantes da Raiz localizavam facilmente hierarquias 
cristalizadas em pessoas ou instâncias específicas. Talvez a exceção ficasse por conta, em um dado período, do coletivo responsável pela comunicação e um ou outro Gt mas, ainda assim, se tratava de uma desconfiança difusa e raramente identificavam um conjunto de decisões relevantes tomadas de modo autoritário ou uma atuação autocrática continuada e sistemática. Assim, para a Raiz a hierarquia se definia, sobretudo, por seu caráter processual e se constituía principalmente nas práticas nas quais alguns agentes poderiam assumir uma posição que lhes permitisse ter influência sobre o funcionamento e decisões do coletivo. Essa influência poderia ocorrer tanto naturalmente (como resultado da participação contínua, capacidade persuasiva ou conhecimento do tema em escrutínio), como ser o resultado de uma ação intencional em que o sujeito supostamente agiria para fazer valer os seus interesses, entendidos geralmente em termos de projetos de poder pessoal. A celeridade percebida no encaminhamento de algumas questões também contribuía para o sentimento de que havia interesses pessoais que atropelavam o devido processo democrático (que necessitava de tempo para envolver as pessoas e para resguardar os princípios da Carta Cidadanista). Sempre foi muito forte a concepção de que a institucionalização apressada da Raiz, isto é, sem que houvesse o tempo necessário para a ampliação da sua base social, pudesse resultar em uma organização partidária hierárquica e burocratizada e bastante permeável a interesses conflitantes com os princípios fundadores da associação.

\subsection{Crise e ocaso do digital}

As eleições municipais de 2016 foram marcadas por uma série de conflitos que trouxeram à tona as tensões constitutivas do modo de organização e funcionamento da Raiz e que têm sido discutidas neste capítulo. Por não terem obtido sucesso na coleta de assinaturas para a regularização partidária, os cidadanistas tiveram que decidir regionalmente como se daria a política de alianças e a sua atuação nas eleições.

Segundo interlocutores, a ausência de uma resolução específica de abrangência nacional sobre as eleições e a necessidade de se organizarem de acordo com o calendário e com as dinâmicas políticas regionais fizeram com que algumas decisões fossem tomadas sem ampla participação e passando por cima de princípios fundamentais da Raiz. O caso mais emblemático dessa situação ocorreu na cidade de Fortaleza, no Ceará, com o apoio do Círculo e da Esfera de Fortaleza a Roberto Cláudio, candidato da coligação PDT/DEM. O problema não estava no apoio ao cabeça de 
chapa do PDT, um partido de centro-esquerda e, de certo modo, alinhado a algumas pautas defendidas pela Raiz, mas à coligação do PDT com o DEM, partido de direita identificado com o que de pior existe na política brasileira e que foi apoiador decisivo do golpe parlamentar que resultou no impeachment da presidenta Dilma Rousseff e contra o qual a Raiz se insurgiu imediatamente. Essa aliança foi considerada bastante desgastante para o coletivo (a deliberação sobre uma moção de desaprovação à iniciativa dos cidadanistas de Fortaleza deixou muito claro esse desgaste), e colocou em evidência a tensão entre autonomia e a manutenção dos princípios do coletivo.

Em São Paulo, a participação do Círculo Sampa na campanha para prefeitura da incentivadora da Raiz, Luiza Erundina, pelo PSOL, embora vista como uma candidatura da própria Raiz, também teve os seus percalços. Os cidadanistas de São Paulo frequentemente reclamavam da centralização das decisões por parte da coordenação de campanha do PSOL que, no seu entender, abriu pouco espaço para a sua participação na determinação dos rumos da campanha e modificou e ignorou propostas para o programa de governo da candidata que foram fruto de construção conjunta entre integrantes da Raiz e do PSOL. Certa rejeição ao PSOL tinha relação com a experiência desse período, que contribuiu para constituir e reforçar uma visão do PSOL como uma organização partidária verticalizada e autoritária (como veremos no próximo capítulo). A experiência eleitoral de 2016 seria uma boa oportunidade para, grosso modo, ativar a Raiz no campo político-partidário e para colocar em prática os princípios políticos tão caros ao movimento. No entanto, os desafios e os conflitos desse período mostraram o distanciamento entre os princípios e a forma organizativa do coletivo, de um lado, e a forma como a prática se deu, de outro, levando a um processo de avaliação interna que culminou no diagnóstico de que seria necessária uma renovação geral da Raiz. A nova estrutura da Raiz contemplou o redesenho das comissões, a redistribuição de funções e o recadastramento dos membros, muitos dos quais sem nenhuma participação nas atividades ou nas discussões presenciais ou online.

A reconfiguração da Raiz também ocorreu no campo do digital de acordo com a percepção geral da necessidade de um site e de uma plataforma para discussão que representassem de forma mais adequada o Movimento Cidadanista. A crítica ao Loomio sempre esteve presente, mas tudo leva a crer que a mudança de plataforma estivesse mais ligada ao espírito de renovação geral e à ideia de criarem um espaço personalizado, mais de acordo com as identificações da Raiz, inclusive esteticamente. Com isso, a plataforma digital Loomio foi abandonada e substituída pelo website da Raiz, com uma plataforma própria para discussão e deliberação. Apesar de ter sido muito celebrada 
pelos cidadanistas, a nova plataforma acabou não sendo adotada como espaço de discussão cotidiana, provavelmente em razão da reestruturação ter priorizado as relações presenciais (mais autênticas) e colocado o digital em segundo plano. Outro fator que parece ter tido algum peso nesse quase abandono do digital foi a saída de alguns cidadanistas do coletivo, que se efetivou digitalmente quando não fizeram a transição de plataforma mediante recadastramento. Por desempenharem um papel secundário nas interações cotidianas do coletivo farei apenas uma breve descrição do website (hospedado no endereço www.raiz.org.br) e do espaço dedicado a discussões e deliberações.

O desenho da página inicial da Raiz foi concebido para dinamizar e promover a participação nos diferentes espaços em que a Raiz estava inserida, o que fica evidente logo na primeira seção.

1. A barra superior na cor cinza-escura continha os links para os espaços digitais de participação da Raiz: primeiro havia, em cor verde, o endereço de correio eletrônico, o link para a Teia Digital e para o Sistema Integrado, espaço acessível apenas para os cadastrados no site (Filiados e Colaboradores), onde havia a listagem e descrição dos Círculos e espaço para anexar documentos e outros materiais. Depois havia, indicado pelo desenho de uma lupa, um campo para pesquisa de conteúdo do site e, por último, os links para as redes sociais Loomio, Facebook, Twitter, Youtube e Telegram.

2. Abaixo havia uma faixa horizontal da cor branca com o logotipo da Raiz e um menu horizontal contendo os links: A Raiz (ao passar com o ponteiro do mouse ou o dedo no touch screen por cima abria um submenu vertical com informações gerais sobre a Raiz, a Carta Cidadanista, Contato etc.), Círculos (permitia acesso aos Círculos existentes), Venha Participar (acessava informações para ingresso na Raiz), Agenda (acessava a agenda de eventos), Biblioteca (abria um menu vertical para acesso a documentos, artigos e manuais), Imprensa (abria um menu vertical para contato com a assessoria de imprensa, fotos e notícias da Raiz na imprensa).

3. A seguir havia um grande painel dinâmico que se destacava logo que a página era carregada e que apresentava, alternadamente, cinco imagens escolhidas pelo administrador do site. 
4. A seção abaixo, Últimas Notícias, era um espaço dedicado a uma seleção de links de notícias, comunicados e outras produções escritas da Raiz e apresentava em um fundo branco: o título, uma imagem e as primeiras frases do texto de cada produção selecionada.

5. A seção seguinte, em fundo cinza-escuro, tinha o link para os quatro princípios fundamentais da Raiz (o Ubuntu, o Teko Porã, O Ecossocialismo e o Consenso Progressivo), com imagem, título e o início do texto apresentando cada princípio. Abaixo havia uma sequência de palavras agrupadas (Nuvem de tags) - com a fonte tipográfica na cor verde, em diferentes tamanhos -, composta por termos associados com o coletivo que, quando clicados, mostravam uma lista do conteúdo do site onde essas palavras estavam presentes.

6. Por fim, também em fundo cinza-escuro, havia os campos para entrar em contato com a administração do site e no rodapé o logotipo da Raiz e os links para as redes sociais. 


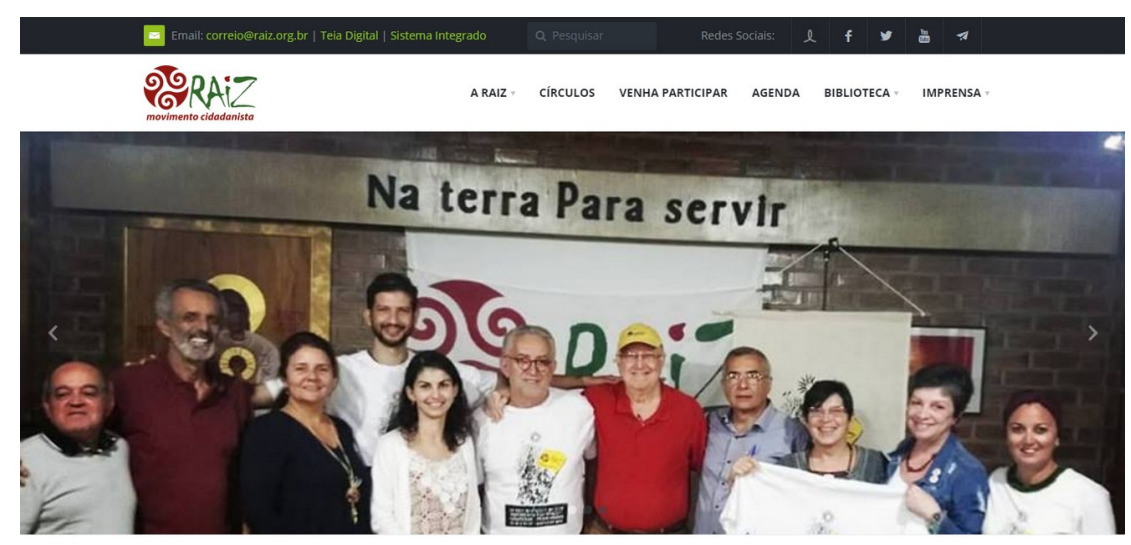

ÚLTIMAS NOTÍCIAS
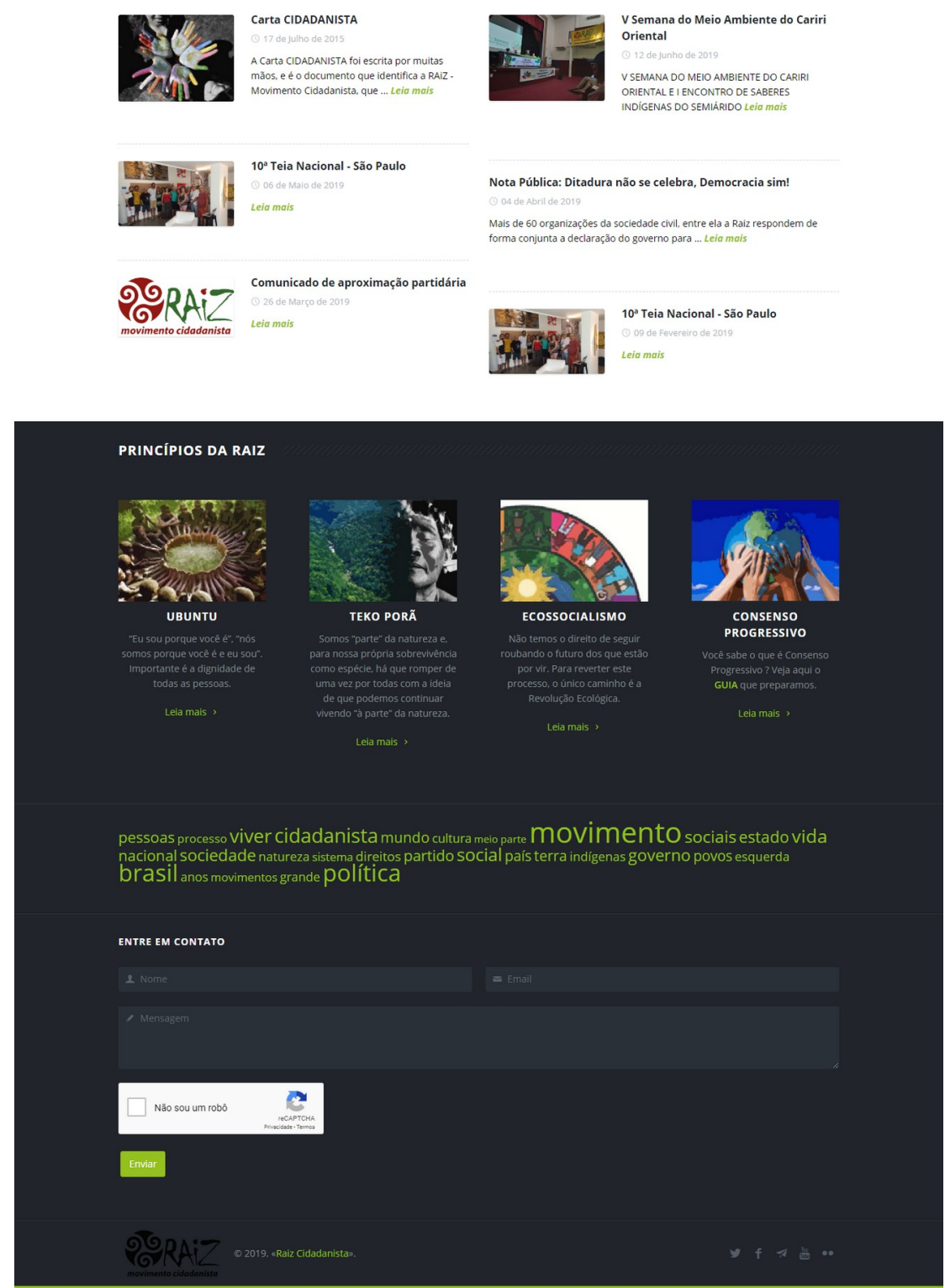

Imagem 4. Página inicial do novo site da Raiz - Movimento Cidadanista. 
A Teia Digital podia ser acessada facilmente por um link posicionado na barra superior da página principal e só permitia acesso aos cadastrados (Filiados e Colaboradores). O link Teia Digital abria uma página com as opções entre a Teia Nacional, Estadual e Municipal e embaixo havia uma seção com quatro imagens que também serviam como links para os textos sobre os quatro princípios da Raiz. Os espaços das Teias tinham o mesmo design com duas seções no canto esquerdo com retângulos alongados em sentido vertical (comprimento). A primeira seção tinha um menu vertical com links que facilitavam localizar discussões: Recentes (mostrava as conversas mais recentes na Teia); Meus grupos (mostrava os grupos nos quais o membro com perfil ativo participava); Não Lidos (tópicos não lidos desde a última visita); Diretório (mostrava todos os grupos existentes); Pesquisa (listava os tópicos por assunto); Meu Perfil (exibia os dados do perfil do membro do site como dados pessoais e grupos dos quais fazia parte); Sair (para sair da Teia e do perfil). A segunda seção (Eventos), logo abaixo, tinha uma lista com o título e a data dos eventos programados em ordem cronológica decrescente e o link para o texto com informação detalhada. Ocupando a maior parte do espaço da página encontravam-se os tópicos de discussão, cada tópico em um retângulo na cor azul-claro que se estendia horizontalmente. Cada retângulo possuía o título do tópico, o autor, a data e hora de início, o número de comentários, o número de pessoas envolvidas na discussão, o grupo ao qual o tópico pertencia e o desenho de uma estrela que servia para marcar o tópico como prioritário quando ativada pelo visitante. 


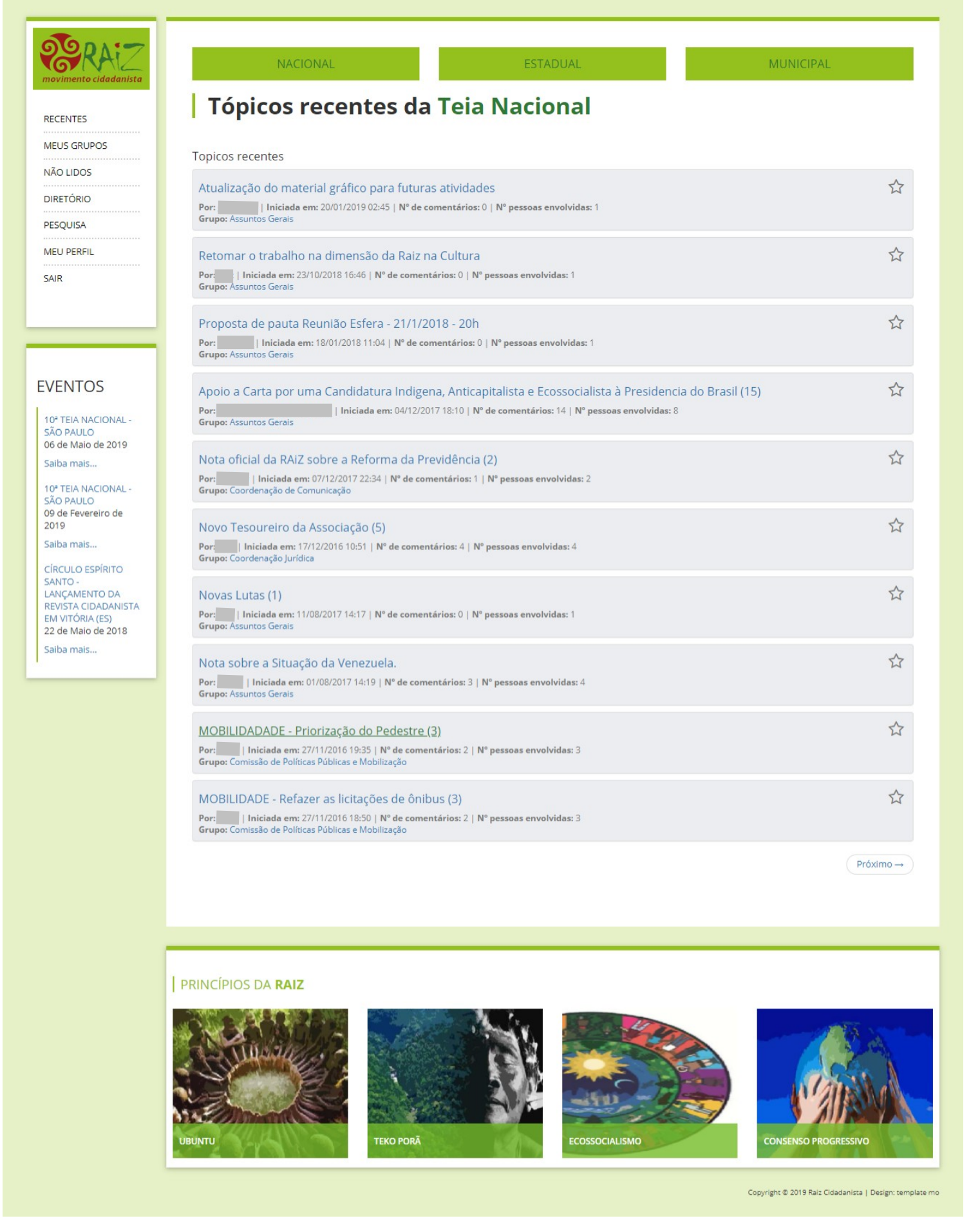

Imagem 5. Nova Teia digital da Raiz.

O espaço destinado às discussões (imagem 5) funcionava basicamente sob a mesma lógica do Loomio com o empilhamento das mensagens em sequência cronológica. Entretanto, havia algumas diferenças que, aparentemente, o tornavam mais organizado, no sentido de que era mais fácil ler, acompanhar o fluxo de argumentos e interagir, se comparado ao Loomio. A área de 
visualização das mensagens era, em largura, quase o dobro do Loomio, o que na prática diminuía a extensão do acúmulo de mensagens e facilitava a busca de um trecho específico do debate - na medida em que era possível ver um número maior de mensagens ao mesmo tempo. Além disso, as mensagens eram apresentadas completas, ao contrário do Loomio onde eram parcialmente exibidas quando muito extensas, sendo preciso clicar em Show more para mostrar o restante do texto. As respostas diretas a mensagens específicas também apresentavam boa visibilidade e adquiriam maior importância estética, se comparadas ao Loomio: eram visualizadas dentro de um retângulo em tom azul-escuro alocado dentro do retângulo azul-claro onde a mensagem original tinha sido escrita, logo abaixo dela (conforme imagem 6). Também era possível utilizar vários recursos para formatação do texto como negrito, sublinhado, itálico (os três recursos só podiam ser usados no Loomio por meio da inserção de tags de edição no texto), listas numeradas ou marcadas, cores para fontes, imagens e Emoticons. Estes recursos permitiam inserir marcas que diferenciavam e destacavam partes da mensagem contribuindo para a ênfase e, talvez, a retenção de um argumento em relação a inúmeras outras ideias presentes na discussão. Tanto a caixa de apresentação do tópico quanto as caixas das mensagens dos participantes possuíam na parte inferior as opções Ciente, Concordo, Concordo em parte, Discordo, Menção (esta última para mencionar pessoas nas mensagens e elas serem avisadas) e Responder (na caixa de descrição do tópico não aparecia essa opção, apenas a indicação Conversa Editada caso ela tivesse sido alterada). A opção Ciente superava uma limitação fundamental do Loomio que era a impossibilidade de mensurar a participação do leitor que não postava mensagens, mas acompanhava as discussões. A possibilidade de sinalizar a leitura de uma mensagem mutatis mutandis transpunha a ideia exposta no capítulo 1 de "escuta ativa e interessada" para o plano da escrita, criando a figura do leitor ativo. O Loomio, por sua vez, apresentava somente a quantidade de pessoas que tinha acessado o tópico em discussão, não havendo nenhuma garantia de que essas pessoas tivessem lido qualquer mensagem. O diferencial mais significativo e, provavelmente, o maior problema do novo espaço de discussão, era que ele propunha o voto para cada uma das mensagens do tópico, o que, como vimos no caso da votação no Loomio, dificultava muito a construção paulatina de alinhamentos. Na nova plataforma cada proposta de discussão acabava sendo também uma proposta de votação, ao contrário do Loomio onde estavam separados, por isso havia situações em que era preciso desencorajar a votação, ao menos por um tempo, como fez João Paulo no final da apresentação de um tópico de discussão: 
IMPORTANTE: Por favor, não adiantem o voto ainda. O tópico inicial fica aberto apenas para sabermos se alguém sugere uma terceira data antes de iniciarmos a votação.

No canto superior direito do espaço de discussão havia uma estrela que possibilitava marcar a discussão como prioritária e do seu lado esquerdo um ícone de um envelope que oferecia algumas opções quando se passava o ponteiro (cursor) por cima dele. Havia opções para marcar a conversa como prioritária (Prioritário), para sempre receber notificações via e-mail (Sempre receber notificações), para ter um resumo diário da conversa via e-mail (Resumo Diário), para receber no email apenas notificações de votação (Apenas notificações de votação) e para não receber nenhuma notificação (Não receber notificações). O Loomio também permitia receber notificações no e-mail de novas participações na discussão, mas não havia tantas opções para configurar o recebimento. 


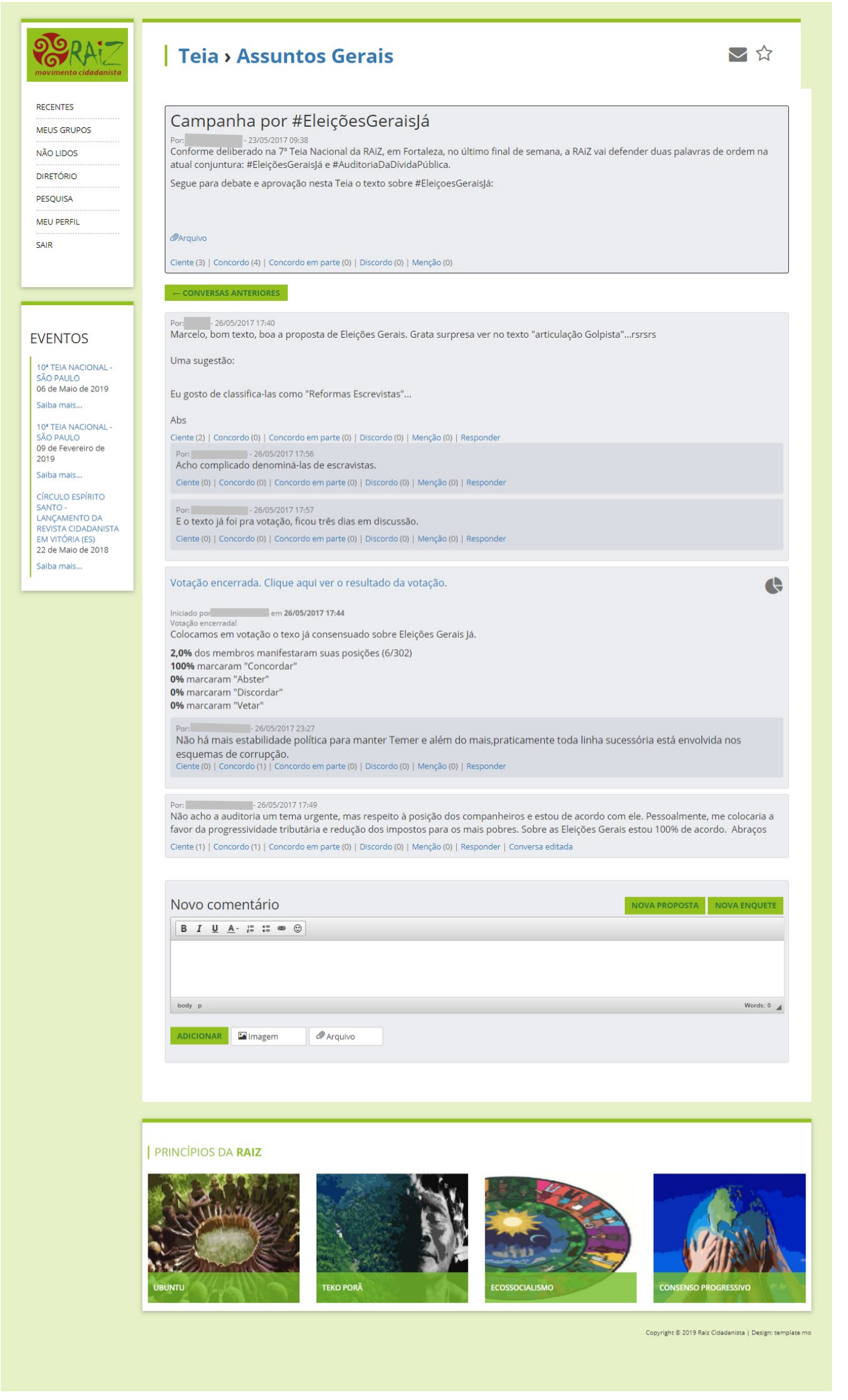

Imagem 6. Tópico de discussão da Teia Nacional da Raiz. 
Quando acionei os links para as diferentes Teias vi que a Teia Municipal digital nunca tinha sido realizada e a Teia Estadual apresentava somente seis tópicos de discussão, podendo ser considerada praticamente inativa. As discussões da Teia Nacional foram realizadas apenas trinta e sete vezes desde o final de 2016 e só em cinco tópicos houve a participação de mais de cinco pessoas. A falta de interação sistemática na Teia Digital torna muito difícil a avaliação dos efeitos da sua arquitetura nas práticas políticas do coletivo, por esse motivo não foi possível uma análise mais pormenorizada. O baixo grau de participação na nova plataforma provavelmente contribuiu para a sensação de que a Raiz estava pouco ativa ou mesmo inativa, sentimento muito presente nas declarações reiteradas de alguns cidadanistas de que a Raiz estava meio parada e de que ela necessitava realizar ações práticas. As interações nos grupos do WhatsApp de algum modo compensavam essa ausência nas plataformas, mas, ao que parece, de forma muitíssimo limitada. Esse aplicativo funcionava e era utilizado de forma bastante diversa de espaços como o Loomio e a Teia digital do site da Raiz. As conversas, quando existiam, costumavam ser muito breves e de caráter principalmente informativo. No dia-a-dia, o WhatsApp funcionava mais como um espaço para compartilhamento de notícias, principalmente sobre o meio político-institucional, uma espécie de repositório de mensagens, memes e notícias com nível relativamente baixo de interação entre os agentes, embora isso tenha mudado consideravelmente no período eleitoral, como veremos no próximo capítulo. Permanecia, portanto, a visão de que a Raiz precisava romper um relativo estado de paralisia e focar nas ações práticas. Seria preciso um grande acontecimento para quebrar esse sentimento de letargia coletiva e para despertar novamente a Raiz. E nada melhor do que uma eleição para isso. 


\section{CAPÍTULO 3. FAZENDO POLÍTICA EM TEMPOS DE CRISE}

O período eleitoral é sempre um momento privilegiado para a compreensão de dimensões estruturantes da política e de outros aspectos-chave da vida social. Contudo, nunca é demais lembrar que, essa dimensão específica da vida social a que chamo política, trata-se, tão somente, de um constructo artificial, destinado a servir como um conceito heurístico para ser preenchido ou deslocado pelas práticas e categorias dos sujeitos pesquisados.

Nas últimas três décadas várias pesquisas etnográficas têm sido dedicadas ao estudo do período eleitoral. O estudo de Moacir Palmeira (1996) sobre a experiência de moradores de pequenos municípios do interior pernambucano no "tempo da política", tornou-se paradigmático no campo da Antropologia da Política e tem se mostrado uma fonte poderosa de insights muito valiosos. O "tempo da política" é, para os interlocutores de Palmeira, (p.50) "o momento em que as faç̧ões (os partidos reais) são identificadas, e em que, por assim dizer, existem plenamente, em conflito aberto, as municipalidades divididas de uma maneira pouco habitual nas grandes cidades". Esse período é marcado por um novo ordenamento das relações sociais e por tornar visível e colocar em evidência aspectos ocultos ou menosprezados da vida social ordinária. Desse modo, alinhamentos de interesses, compromissos e alianças são estabelecidos e sinalizam a abertura para novas relações assim como fraturas no tecido social são expostas ou podem surgir nesse momento. Mutatis mutantis, a análise de Palmeira pode ajudar a iluminar alguns aspectos da forma como o período eleitoral foi vivenciado pelos sujeitos que fizeram parte da minha investigação. Mas enquanto a maior parte dos relatos etnográficos apresenta o período eleitoral a partir do modo como foi experimentado pelos eleitores, minha pesquisa privilegiou a perspectiva da candidatura ao cargo eletivo.

Este capítulo tem como objeto central as práticas políticas do coletivo Mandato Cidadanista na cidade de São Paulo em torno da candidatura de Célio Turino à vaga de deputado federal pelo Estado de São Paulo. A pesquisa de campo abrangeu o período eleitoral que foi de agosto a outubro de 2018 e o período subsequente, que se estendeu até a Teia Nacional da Raiz, realizada em São Paulo, em fevereiro de 2019. A análise da experiência do coletivo na campanha eleitoral revela como em uma lente de aumento as dinâmicas constitutivas do seu modo de existência bem como as práticas, significados e dilemas que tomaram forma a partir da situação da corrida eleitoral. As eleições de 2018 adquirem uma importância adicional em razão do cenário de crise (político- 
institucional, econômica e social) que tem assolado o país e que se traduziu no profundo descrédito das instituições, na polarização político-ideológica e na ascensão do autoritarismo e de diversas formas de violência política. A candidatura de Jair Bolsonaro soube muito bem capitanear esse descontentamento e foi, de certo modo, um grande catalisador de uma onda reacionária, marcando fortemente a disputa eleitoral em todos os níveis. Essa situação provocou, entre meus interlocutores, um notável deslocamento do sentido de resistência, noção que sempre esteve presente em suas práticas discursivas. Comumente associada a uma recusa ao neoliberalismo e suas consequências nefastas, a resistência passou a assumir o sentido de defesa imediata contra os ataques desferidos à democracia e a direitos e valores fundamentais. O primeiro sentido mobilizado na noção de resistência aponta para uma recusa ativa, isto é, para a ideia de construção criativa de novas formas de agir no mundo que subvertam as lógicas sobre as quais está assentado o capitalismo contemporâneo, enquanto que, no segundo, a resistência está, sobretudo, relacionada a uma recusa negativa, de caráter reativo. É claro que, na realidade, as coisas se mostravam de modo muito mais complexo, já que esses significados nunca se cristalizaram como duas alternativas estanques e exclusivas prontas para serem escolhidas de acordo com as situações. Práticas políticas como a participação em frentes de mobilização pela democracia, que construíam e acionavam os significados associados à resistência reativa, também promoviam formas de 'fazer-junto' que apontavam para múltiplos outros sentidos, inclusive aqueles que constituíam a noção de resistência ativa. Assim podemos entender a evolução de pequenas frentes de resistência, organizadas por cidadanistas dos bairros de Ermelino Matarazzo e Itaquera logo após a vitória de Bolsonaro que, partindo de uma recusa com sentido negativo, atuaram na constituição de práticas e significados com caráter fortemente construtivo.

Em março de 2018, o Partido Socialismo e Liberdade (PSOL), fez um convite ao Célio Turino da Raiz de São Paulo para ser candidato a deputado federal pelo partido. Célio Turino atuou por mais de 30 anos junto a movimentos culturais e sociais e foi cofundador da Rede Sustentabilidade - até seu rompimento com a associação nas eleições de 2014 - e depois atuou, junto a sua companheira de vida e luta, Silvana, na fundação da Raiz, sendo, desde então, um dos membros mais atuantes na construção do movimento. Após o convite do PSOL, Célio se reuniu com integrantes da Raiz para falar da proposta e dizer que não queria ser candidato de si (mim) mesmo e que só seria candidato se fosse representando um grupo. E assim surgiu o projeto da candidatura e do mandato coletivos, com uma gestão compartilhada da candidatura e a 
proeminência de Turino no plano da comunicação com o eleitorado, uma vez que ele seria oficialmente o nome na urna.

Embora o Mandato Cidadanista (MC) tenha sido constituído majoritariamente por integrantes da Raiz e baseado nos princípios cidadanistas (da Raiz), ele não foi, em sentido estrito, uma ação da Raiz, já que não houve discussão e decisão oficial acerca do assunto. Nesse momento a Raiz era vista como em um estado de quase paralisia enquanto coletivo, embora alguns integrantes continuavam em seus ativismos vendo-se como atuando pelo movimento. Diante desse quadro de inatividade e da ausência de uma resolução de caráter nacional sobre candidaturas por siglas partidárias (o que já tinha provocado um grande desgaste na eleição anterior), os cidadanistas do Estado de São Paulo optaram por constituírem um coletivo autônomo. Confesso que quando recebi por e-mail um convite para apresentação do Mandato Cidadanista, na pré-campanha eleitoral, para mim se tratava de uma atividade da Raiz e ao saber no campo que aquele coletivo não era uma instância da Raiz criada para disputar a eleição me senti bastante frustrado, afinal de contas o meu objeto de estudo era a Raiz - Movimento Cidadanista. Ao adentrar o debate promovido na sede de campanha do Mandato minhas primeiras perguntas foram acerca das atividades da Raiz e sobre o processo de institucionalização como partido, ao que as respostas eram sempre pouco esclarecedoras, com frases e termos que eu passaria a escutar repetidamente a partir dali: a Raiz estava meio parada, hibernando, paralisada, entre outros. Mas se meus interlocutores eram praticamente unânimes em dizer que o Mandato Cidadanista não era a Raiz, ao examinar o material explicativo e ao conversar com os presentes, logo percebi que os componentes do Mandato eram praticamente os mesmos da Raiz, que o modo de organização também era muito semelhante, que os princípios acionados eram aqueles presentes na carta fundadora da Raiz, em suma, que ali havia algo muito significativo que imediatamente transformou a minha frustração inicial em estímulo e curiosidade intelectual. Esse primeiro choque com a chegada ao campo, que se repetiu em certos momentos da pesquisa, logo mostrou que a frustração era nada menos que um resquício de concepções teóricas bastante limitadoras como a de grupo como entidade substantiva com fronteiras bem definidas, uma ideia que foi desafiada já no processo de formação da Raiz, como vimos no capítulo 1. Com o passar do tempo, alguns cidadanistas foram deixando cada vez menos nítida a distinção entre o Mandato e a Raiz a ponto de alguns se referirem ao Mandato como a Raiz na prática. Seja como for, a experiência do Mandato colocou novamente em discussão a Raiz como projeto coletivo e representou para os cidadanistas uma espécie de reavivamento do movimento. 
A chapa do Mandato Cidadanista seguiu uma nova tendência na política brasileira de mandatos coletivos que têm questionado e procurado subverter as formas institucionalizadas de fazer política. A Bancada Ativista, em São Paulo, e o coletivo Juntas, em Pernambuco, estão entre as iniciativas mais conhecidas de mandatos coletivos que obtiveram sucesso eleitoral.

Em São Paulo, a Bancada Ativista foi eleita para a assembleia legislativa estadual com 149.844 votos, ficando em décimo lugar no estado. O coletivo tinha nove integrantes e era formado em sua maioria por mulheres. Em Pernambuco, o Juntas, coletivo formado por cinco mulheres, foi eleito para a Assembleia estadual com 39.175 votos. A possibilidade de mandatos coletivos não é reconhecida e regulamentada pela legislação eleitoral brasileira, o que faz dessas iniciativas arranjos informais sujeitos às formas e limitações dos dispositivos legais. A lei diz que a candidatura é individual e só permite um nome com foto na urna e apenas um candidato eleito pode ocupar a cadeira e votar nas deliberações das assembleias. Mas há a possibilidade de registrar um nome que não seja o do registro civil do candidato, abrindo uma brecha para o registro dos nomes dos coletivos. Na Bancada Ativista, o nome mostrado na urna era composto pelo primeiro nome da candidata somado ao nome do coletivo (Mônica da Bancada Ativista), enquanto no Juntas, aparecia somente o nome do coletivo com a foto da Jô Cavalcanti, a candidata registrada na justiça eleitoral. Os dois coletivos defendiam o exercício do mandato compartilhado entre os seus integrantes de modo que todas as decisões deveriam ser tomadas em conjunto, buscando o consenso. Por isso cada membro do mandato era considerado, internamente e para os seus eleitores, um(a) codeputado(a), embora oficialmente esse termo não tivesse qualquer efeito legal. Esse modelo de ação política coletiva era então baseado fundamentalmente na confiança, já que esses arranjos poderiam ser desfeitos a qualquer momento e@s codeputad@s excluídos do mandato por uma simples decisão do candidato oficialmente eleito. Embora ainda seja cedo para avaliar o funcionamento dessas e outras iniciativas nos parlamentos, talvez já seja possível afirmar que elas têm se mostrado formas efetivas de inclusão de ativistas, minorias e categorias sociais que sempre foram sub-representadas no âmbito político-parlamentar. São mulheres, negros, LGBT’s e moradores das periferias que, não apenas estão começando a ocupar um espaço preponderantemente branco, de classe média, masculino e heteronormativo, mas também podem funcionar como elos de ligação efetivos entre o Estado e as demandas dessas pessoas. Outra característica importante dessas candidaturas é o seu caráter marcadamente identitário, no sentido de que elas se concebem como representativas e sensíveis às demandas de segmentos sociais específicos - que possuem marcadores sociais que foram e continuam sendo utilizados pelos detentores do poder para manutenção da sua situação de 
exclusão - e, com isso, têm conquistado o apoio de eleitores que também se identificam politicamente com essas categorias, o que pode ser percebido tanto na atuação dos ativistas que compõem os coletivos, quanto nos discursos de campanha e nas características do eleitorado ao qual são direcionadas as ações de campanha. Nesse aspecto, o MC se diferenciava decisivamente dessas candidaturas, uma vez que, reiteradamente os cidadanistas se posicionavam criticamente contra alguns aspectos do ativismo identitário, sobretudo, em relação a sua suposta tendência em fomentar divisões sociais e dificultar uniões em frentes de luta mais abrangentes. No entanto, o quadro de polarização eleitoral parece ter favorecido, no campo da esquerda, as candidaturas identitárias, com candidatos eleitos em várias regiões do país, o que, na visão de alguns cidadanistas, foi uma tendência que tornou ainda mais difícil a obtenção de sucesso nessas eleições.

As candidaturas da Bancada Ativista, do Juntos e do Mandato Cidadanista foram pelo Partido Socialismo e Liberdade, uma agremiação partidária que tem apoiado várias iniciativas do gênero no país. Entretanto, com exceção do Juntos, nem todos os componentes dos coletivos eram filiados ao PSOL, inclusive, na Bancada havia uma codeputada alinhada ao PT e, no Mandato, alguns viam o PSOL mais como um instrumento necessário diante da conjuntura política e da falta de uma alternativa melhor. As consequências desse empréstimo da legenda para movimentos que operam de forma autônoma em relação aos partidos só agora começam a ser discutidas no Brasil, mas não há dúvidas de que se trata de uma relação que não está isenta de tensionamentos, embora comumente se reconheça na abertura e no apoio dispensado pelos dirigentes partidários um ato de extrema boa vontade e generosidade.

A proposta do Mandato Cidadanista foi resultado de construção coletiva e foi concebida como um modelo não acabado, aberto a reformulações. O Mandato foi assim constituído:

1. Time de codeputad@s. Pensado como a instância mais importante e definidora do Mandato, foi formado por oito codeputadas e cinco codeputados voluntários, atuantes em diferentes causas que seriam as suas principais áreas de atuação no Mandato. Deveriam elaborar propostas de leis, realizar estudos e consultas à população, fazer a articulação do mandato com as bases e atuar juntamente ao deputado eleito na tomada de decisões relativas ao mandato e às votações na câmara federal. Segue abaixo a relação de codeputad@s:

Aluízio Marino - Cultura digital e ocupações culturais

Baby Amorim - Pontos de Cultura

Bruna Reis - Parto humanizado e oeste paulista 
Cristine Takuá - Povos indígenas

Deise Mara - Campinas e região

Dennis Oliveira - Antiracismo e comunicação democrática

Eduardo Brasileiro - Igreja Progressista

Magno Oliveira - Juventude e Alto Tietê

Ondalva Serrano - Agroecologia

Rafaela Guabiraba - Ermelino Matarazzo

Surya Guimaraens - Igualdade de gênero

Thaynah Gutierrez - Estudantes

Thomás Enlazador - Socioambientalismo e Permacultura

Podemos ver que ao lado dos nomes dos componentes há a indicação dos ativismos principais aos quais se dedicavam ou das regiões onde atuavam politicamente, de acordo com a forma escolhida para apresentação ao eleitorado. Enquanto alguns pensavam suas ações como ligadas a temáticas que ultrapassavam uma região, outros viam mais o seu ativismo como localizado territorialmente (podendo até abarcar diferentes esferas de atuação) ou concebiam o seu campo de luta tanto em relação a temáticas específicas quanto a localidades. Essa especificação e divisão dos ativismos e das regiões de atuação é um tanto simplista pois, na prática, a ação dos cidadanistas sempre ultrapassava esses campos, os quais se encontravam ligados de múltiplas formas, como no caso da Thaynah, cuja atuação na luta estudantil aproximava-a naturalmente do ativismo pela igualdade de gênero.

2. Observatório Cidadanista. Consistiria na abertura de vários canais de interlocução com a sociedade que incluiriam a comunicação pelas redes sociais, reuniões online e presenciais com o representante eleito e codeputad@s, a promoção de consultas populares e, principalmente, a construção de uma plataforma virtual própria para a participação da população.

3. Conselho de visões. Seria um conselho consultivo formado por pessoas com reconhecido conhecimento e experiência nas áreas de atuação do Mandato.

4. Núcleo Executivo. Incluiria o Célio Turino como deputado eleito e uma equipe executiva com profissionais das áreas jurídica, comunicação, alguns interlocutores (que fariam as pontes com as outras instâncias do Mandato), entre outros que se mostrassem necessários para o funcionamento do Mandato. 
5. Plataforma digital de decisão compartilhada Rios. Pensada para ser o principal canal de interlocução com o eleitorado, a plataforma digital Rios seria construída de maneira a proporcionar uma experiência de participação mais inclusiva e de acordo com os princípios e o modo de funcionamento do Mandato.

Essa configuração do MC era considerada um modelo de participação política com enorme potencial de agregar apoio dos eleitores, cada vez mais descontentes com as candidaturas convencionais. No entanto, durante a campanha percebi certa falta de clareza por parte de alguns codeputad@s quanto ao funcionamento do Mandato na prática, o que mais tarde, na avaliação da campanha, foi também um dos principais pontos negativos levantados pelos cidadanistas. Mesmo acreditando na ideia, continuamente reafirmada, de que o plano sempre seria ajustado e transformado no momento da sua realização prática, o conhecimento em profundidade do modelo era visto como imprescindível para compreensão do cerne do projeto político do coletivo e para a comunicação com outros sujeitos políticos. Parece tratar-se menos de saber exatamente o que iriam fazer se fossem eleitos e mais de demonstrar e reconhecer fazer parte de um coletivo por meio da posse compartilhada de um saber. O domínio desse saber também era visto como indispensável para o contato com o eleitorado, uma vez que se supunha que o eleitor associaria diretamente esse conhecimento com a capacidade de organização e atuação política da candidatura. E isso chama a atenção para outro ponto.

É muito comum nas campanhas eleitorais práticas de interpretação do comportamento do eleitorado e tentativas de prever seus pensamentos, desejos e intenções a fim de que a candidatura e os executores da campanha possam modular as suas ações e discursos para conquistar os eleitores e angariar o seu apoio e votos. Mesmo nos casos em que os estrategistas da campanha estão munidos de pesquisas e informações acerca do perfil do eleitorado, sobra um grande espaço para suposições e conjecturas. Apesar de reconhecerem repetidamente as dificuldades de uma campanha eleitoral, os cidadanistas acreditavam que o seu modelo de mandato participativo seria a resposta para o suposto desejo do eleitorado por mais participação na política institucional - apoiados, sem dúvida, nas inúmeras análises sobre a crise política brasileira dos últimos anos - e que o desafio seria, unicamente, apresentar a sua proposta para o maior número possível de pessoas, as quais estariam naturalmente propensas a aderir à candidatura. Então, para terem sucesso na conquista do eleitorado seria preciso, na medida do possível, realizar uma abordagem mais cuidadosa, com mais vagar, pois assim poderiam apresentar adequadamente o projeto cidadanista. Mesmo as atividades de distribuição de material impresso, que normalmente implicam um contato mínimo com as pessoas, 
privilegiavam a interação e a conversa com os passantes que indicavam ter maior disposição para o diálogo.

Ao acompanhar as ações de panfletagem dos cidadanistas em um terminal de ônibus urbano no bairro de Itaquera, ficou bastante clara a diferença entre a panfletagem de outros candidatos (feita, majoritariamente, por funcionários contratados) e a panfletagem qualificada do Mandato (realizada pel@s própri@s codeputad@s, contratad@s e voluntári@s). Em primeiro lugar, vi que, ao contrário das pessoas que trabalhavam para outras candidaturas, não havia uma meta quantitativa de material a ser distribuído ou tempo determinado para a execução da ação. Também não havia o senso de urgência para atingir o maior número possível de passantes ou para terminar o trabalho rapidamente para retornarem às suas casas, pelo contrário: procuravam quase sempre estabelecer um diálogo com as pessoas que perguntavam sobre o material ou sinalizavam interesse pelo mesmo. Aliás, um tempo depois do início da ação, percebi que a distribuição de material nas filas dos pontos de parada dos ônibus passou a ser preferida em relação à distribuição nos locais de grande fluxo de pessoas, uma vez que, nos pontos, as pessoas geralmente olhavam o material e estavam mais inclinadas a ouvir e conversar - uma estratégia, sem dúvida, ineficiente do ponto de vista meramente quantitativo. Essas situações de campanha desvelam elementos que apontam para os modos de organização e funcionamento do Mandato Cidadanista, como, por exemplo, as formas de engajamento dos membros do MC na campanha eleitoral e o seu papel na definição das estratégias de campanha, como veremos adiante.

\subsection{Construindo um campo}

Em razão de não haver uma agenda de atividades presenciais da Raiz em São Paulo e da quantidade imensa de material escrito para ser analisado, o meu contato com o coletivo, no primeiro semestre de 2018, restringia-se basicamente ao acompanhamento das suas redes sociais digitais e à leitura dos e-mails que, poucas vezes, recebia. Como eu estava planejando fazer a minha pesquisa de campo presencial no começo do segundo semestre de 2018, a minha percepção de inatividade da Raiz não deixava de me causar alguma apreensão, até o primeiro domingo de junho quando recebi um longo e-mail (especificamente, uma carta enviada por mala-direta) do Célio com o título: Apresentação do Mandato Cidadanista - Célio Turino. O texto fazia uma apresentação da proposta do mandato coletivo e da candidatura do Célio à deputado federal pelo PSOL e convidava os 
destinatários para um arraial (uma festa ao ar livre muito comum no meio do ano) onde seria apresentado o Mandato. A carta ainda mencionava o fato de não terem conseguido legalizar a Raiz, algo que eu sabia, mas da forma como estava escrita, fui levado a ter dúvidas em relação à continuidade do movimento, embora, por outro lado, ali estava claro para mim que os cidadanistas permaneceriam atuando juntos. Como já estava com compromisso marcado, tive que aguardar o encontro seguinte, que ocorreu no começo do mês de agosto na sede de campanha do Mandato Cidadanista, um imóvel emprestado localizado em um bairro nobre da zona oeste de São Paulo. O encontro foi divulgado na página do Mandato no Facebook e por e-mail e consistiu em um bazar (Bazar Cidadanista) para arrecadação de recursos para a campanha com um debate sobre colorismo $^{26}$. Ao chegar no local do encontro, adentrei a área externa ao imóvel, onde estavam sendo vendidos os itens doados para o bazar, e cumprimentei o Thomaz, um dos codeputados que estavam organizando a atividade. Expliquei brevemente o meu intento e, com um entusiasmo notável, Thomaz me convidou para entrar na sala onde estavam iniciando o debate, então me acomodei discretamente em uma das cadeiras próximas à porta e comecei a assistir à discussão - que me parecia bastante acalorada embora poucos entre os presentes falassem. Nesse momento eu não fiz nenhum tipo de registro ou anotação, já que minha intenção era unicamente conhecer as pessoas e ser aceito como pesquisador.

Quando fui para o campo pela primeira vez não esperava que a minha trajetória política e a trajetória do Mandato fossem se cruzar de modo tão inesperado. Dias antes da minha entrada no campo, um amigo de infância, dirigente regional de um dos maiores sindicatos do país e excompanheiro de luta no movimento cultural, apresentou-me um candidato do bairro de Ermelino Matarazzo (bairro no qual residimos, na periferia da zona leste de São Paulo) que iria concorrer a uma cadeira na assembleia estadual e que necessitava de apoio e pessoas para trabalhar em sua campanha. Em razão dos meus compromissos acadêmicos e da minha dedicação prioritária ao trabalho de campo, recusei a participação direta na campanha, embora tivesse garantido o meu apoio à candidatura. Quando cheguei ao campo esperava uma candidatura que tivesse sua base eleitoral (no sentido de zonas territoriais que supunham haver potencial eleitoral e nas quais, por esse motivo, as ações de campanha seriam concentradas) em bairros de classe média e nas regiões

26 O colorismo é uma teoria de origem estadunidense que relaciona a discriminação social à tonalidade da pele, ou seja, quanto mais clara a pele de uma pessoa, mais fácil é a sua aceitação na sociedade. Enquanto o racismo se baseia na discriminação do sujeito por identificá-lo como pertencente a uma raça, o colorismo é a discriminação baseada, essencialmente, na cor da pele. No Brasil, o colorismo também levaria em consideração as características fenotípicas dos sujeitos como o cabelo (se é mais crespo ou mais liso) ou nariz (se é mais largo ou mais fino), por exemplo. O termo apareceu pela primeira vez em um ensaio da escritora Alice Walker intitulado "If the Present Looks Like the Past, What Does the Future Look Like?” e que foi publicado no livro “In Search of Our Mothers”, em 1982. 
mais centralizadas da cidade, uma vez que a maioria dos membros mais participativos da Raiz apresentava esse perfil socioeconômico - e sem contar que a sede de campanha se encontrava localizada em um bairro de classe média alta da cidade. Fiquei bastante surpreso ao saber que o Mandato Cidadanista teria como reduto eleitoral justamente o bairro de Ermelino e Itaquera, o que, em um primeiro momento, não deixou de me causar algum desconforto. Em primeiro lugar, eu sabia que o candidato que eu apoiava fazia dobradinha com o candidato a deputado federal do seu partido, o PC do B e, portanto, haveria, em tese, uma disputa pelo mesmo eleitorado. Em segundo lugar, a minha atuação pregressa como professor da educação básica e como ativista cultural no bairro poderia me colocar em algumas situações desconfortáveis, principalmente por conhecer um grande número de pessoas e ter estabelecido com elas boas e más relações, embora não visse nisso nada que inviabilizasse o meu trabalho. Ao contrário da segunda razão do desconforto, que depois me pareceu banal, a primeira me colocava em uma posição bastante delicada do ponto de vista ético e das possibilidades de acesso ao campo. Ao final do encontro, estabeleci-me em uma roda de conversa informal e, ao me identificar como morador de Ermelino, imediatamente meus interlocutores disseram que havia no coletivo codeputad@s do bairro e que ele seria um dos locais principais de ação na campanha. Assim, senti a necessidade imediata de falar do meu apoio ao Luís França, ainda que esse fato pudesse me colocar em uma posição suspeita dentro do coletivo. Mas, felizmente, não só a minha expectativa de ser percebido com um adversário político era falsa, como havia uma integrante do coletivo que também apoiava o mesmo candidato - algo que soube depois já que ela não esteve presente neste encontro. Foi então que, no espaço de uma hora, passei de espião político do candidato adversário a facilitador de uma aproximação entre os dois candidatos, iniciando, dias depois, os primeiros contatos com o Luís França para uma reunião com o Célio e sua equipe.

É muito instrutivo pensar como o trabalho de campo nos coloca diante de situações difíceis e que são, muitas vezes, impossíveis de serem antecipadas por qualquer manual de campo ou reflexão a priori. Como estudante de Antropologia, sempre esperei que o campo me levasse por caminhos imprevisíveis, que desafiassem a minha capacidade analítico-descritiva, afinal de contas, é por essa razão que eu optei pela disciplina antropológica no lugar da Sociologia. No entanto, é realmente impressionante o modo e a rapidez com que, muitas vezes, o campo retira o pesquisador da sua zona de conforto e o obriga a compor com as circunstâncias. Mesmo sabendo que a Antropologia tem nos últimos anos estimulado os etnógrafos a participarem ativamente das atividades dos seus interlocutores, sempre pensei que, em linhas gerais, poderia ter uma atuação bastante discreta, não 
por crer na capacidade de distanciamento analítico do pesquisador, mas por estar mais de acordo com a minha personalidade. Embora posteriormente eu tenha conseguido manter uma atuação bastante condizente com o meu perfil, nunca deixou de estar presente em mim a sensação de que, em inúmeras ocasiões, o campo dita os seus próprios termos de engajamento e que não nos resta outra coisa senão a abertura ao inesperado que, por si só, já pode ser uma grande recompensa.

Se, por um lado, não podemos antecipar como as coisas vão ser no campo e, portanto, fórmulas e modelos de ação se mostram quase sempre descartáveis, todos os caminhos da etnografia devem passar por ações pautadas pela ética e pelo profundo respeito aos sujeitos que tão generosamente nos acolhem em suas vidas. Apesar de nem sempre na prática os limites da ética serem tão nítidos quanto possam parecer em discussões abstratas, na maioria das vezes, uma conversa franca com nossos interlocutores é suficiente para iluminar as nossas ações. Era evidente que o vínculo com duas candidaturas em uma mesma região, mesmo que não fosse de adversários diretos (um candidato a deputado estadual e outro a federal), sugeria um problema ético considerável. Isto posto, não havia saída possível que não passasse pela explicitação desse vínculo e a atuação a partir do novo campo de possibilidades configurado a partir desse ato.

Felizmente, esse primeiro contato contribuiu para que eu fosse muito bem recebido no campo e meus interlocutores sempre se mostraram muito solícitos sempre que eu precisei. É muito provável que o fato de eu me reconhecer no mesmo campo político que eles tenha sido decisivo para essa aceitação, inclusive, minha escolha da Raiz como objeto de estudo foi justamente por acreditar que a construção de uma democracia digna desse nome depende, direta ou indiretamente, do surgimento de novos experimentos políticos, como os que têm surgido nas últimas décadas. No entanto, em alguns momentos foi perceptível algum desconforto com minha condição de pesquisador, sobretudo quando se tratavam de discussões sobre assuntos relativos a situações de conflito entre cidadanistas. Também, a princípio, não lhes estava muito clara a natureza do trabalho de campo na Antropologia, de modo que, em três ou quatro conversas, percebi que alguns esperavam que eu participasse de uma ou outra reunião para coletar dados e logo a pesquisa no campo já estaria terminada. Essa concepção da pesquisa fez com que, no começo, eu não tivesse sido convidado para algumas atividades, por suporem que aquelas ações seriam pouco significativas e destituídas de interesse para mim. Isso chama atenção para as diferenças internas de perspectivas em relação à minha pesquisa, inclusive sobre alguns aspectos fundamentais, o que em larga medida é de minha total responsabilidade. Além da apresentação da minha pesquisa em reuniões mais gerais, fiz pequenas apresentações na medida em que fui conhecendo alguns integrantes do 
Mandato, muitas vezes, de modo muito superficial. Algumas atividades externas, como manifestações e carreatas no centro da cidade, pareciam pouco propícias a apresentações, já que as pessoas estavam sempre em movimento e me parecia mais sensato esperar por momentos oportunos do que intervir desnecessariamente no ritmo de suas atividades.

\subsection{Construindo o Mandato}

O número de codeputad@s e a composição geral da chapa do mandato foram estabelecidos em comum acordo entre os integrantes do coletivo, levando em consideração, tanto a sua vontade e disponibilidade para participar, como seu histórico de atuação política e a diversidade de regiões, esferas de atuação e categorias sociais, com atenção especial àquelas politicamente subrepresentadas. Em relação à representação por gênero havia, como vimos anteriormente, oito

mulheres e seis homens. Apesar das mulheres estarem bem representadas na composição do Mandato o fato do candidato oficial ser um homem não deixou de ser reconhecido internamente como uma limitação incômoda do arranjo criado pelo coletivo e essa visão também foi manifestada por alguns coletivos de mulheres que, por esse motivo, hesitaram em estabelecer alianças com o Mandato. Por isso houve posteriormente, nas reuniões de avaliação das eleições, a proposta para escolherem uma mulher como cabeça de chapa para as eleições seguintes, em 2020. No que diz respeito à composição etária, o $\mathrm{MC}$ apresentava uma distribuição bem equilibrada, abarcando membros nas faixas dos 20,30,40, 50 e 60 anos (com alguns poucos integrantes acima e abaixo dessas faixas - aqui também levando em consideração os demais membros da chapa do MC, para além d@s codeputad@s), com prevalência das faixas etárias médias.

A chapa do Mandato não deve ser confundida com o modelo proposto para o Mandato depois de eleito. A chapa contou, para além do candidato a deputado, codeputad@s e membros com função executiva, com uma equipe de apoiador@s e voluntári@s que, além de terem sido imprescindíveis para a realização das ações de campanha, também foram fundamentais para atualizar e conformar os significados atinentes ao Mandato Cidadanista e à política para esses agentes. No começo da campanha, por vezes cheguei a pensar que alguns voluntári@s eram codeputad@s, tal era o grau de envolvimento na definição das estratégias e das ações de campanha. De fato, alguns voluntários tiveram participação mais marcante (engajada) que alguns codeputad@s, o que, sem dúvida, serviu para consolidar a visão de que estes últimos poderiam ter 
se dedicado mais. Mas o importante é que esses voluntários conquistaram reconhecimento e adquiriram certa proeminência no coletivo justamente em função desse engajamento e isso remete diretamente à questão da autonomia.

A expectativa dos cidadanistas era de que todos tomassem para si a iniciativa de pensar e desenvolver ações, sem depender da condução ou da liderança dos companheiros mais ativos, como às vezes acontecia. Assim, a elaboração da agenda e das estratégias de campanha dependia decisivamente da participação dos membros do coletivo nas reuniões de campanha. Esperava-se, portanto, que um cidadanista residente e atuante em Ermelino Matarazzo pensasse ações e atividades de campanha no bairro, como foi, por exemplo, a organização de reuniões com a comunidade e a montagem da banca do Mandato na feira livre de quinta-feira. Mas, na realidade, os cidadanistas não chegavam simplesmente nas reuniões já com as propostas de ações fechadas, prontas para serem comunicadas a todos.

A construção de uma agenda de campanha também dependia fortemente da atuação de um coordenador ou facilitador nas reuniões, papel desempenhado por Ivan. A sua atuação não consistia na determinação unilateral de uma agenda, mas, sobretudo, na sugestão de atividades e na coordenação da reunião com o intuito de estimular os agentes a proporem e criarem suas próprias iniciativas. É preciso reconhecer que, quando Ivan perguntava a respeito do andamento das ações nas regiões de atuação dos cidadanistas ou sugeria a presença do coletivo em eventos que ele entendia como importantes para a campanha, essas intervenções raramente eram entendidas como uma requisição de prestação de contas ou uma forma de pressão. Mas se tratava, antes de tudo, de uma cobrança difusa, em prol do coletivo, ou seja, em nome de um compromisso que todos assumiram ao aceitarem fazer parte do Mandato Cidadanista (houve, inclusive, um pacto cidadanista). Nunca presenciei a solicitação direta para que um ou alguns membros específicos do Mandato cumprissem suas obrigações ou se dedicassem mais às suas atividades. $\mathrm{O}$ que havia era, sobretudo, o pedido para que todos, indistintamente, se empenhassem mais e, algumas vezes, reclamações genéricas de que havia dias na agenda que não tinham sido preenchidos com atividades, algo que era visto como um grande problema tendo em vista a enorme quantidade de eleitores a serem conquistados em um intervalo de tempo tão curto. A prática de incitar os cidadanistas a falarem sobre suas ações funcionava, por um lado, como uma forma de lembrá-los de sua responsabilidade para com o coletivo - sem a necessidade de uma cobrança direta, que poderia ser interpretada como um excesso autoritário - e, por outro, era um modo de reforçar o sentido de urgência que a campanha eleitoral requeria para ser vitoriosa (preocupação que sempre foi 
antagônica ao pensamento político cidadanista). Também houve nessas reuniões uma rica troca de experiências, permitindo que os agentes aumentassem o seu repertório de ideias e estratégias a ponto de, em certas ocasiões, ações terem sido combinadas e incluídas na agenda logo após relatos de realização de atividades inspiradoras. Muitas vezes os cidadanistas combinavam as ações de campanha entre eles, sem qualquer tipo de mediação, tomando apenas o cuidado de informá-las posteriormente para o coletivo e o coordenador. Assim, a frequência, o local e o tipo de ação eram em larga medida determinados pela disposição e disponibilidade (de horário e lugar) dos envolvidos, tudo combinado de modo muito simples e pragmático, bastando, para originar uma ação, a simples pergunta: vamos fazer? O importante era que todos estivessem em ação nas ruas, parques, terminais de ônibus, eventos, centros comunitários, enfim, que tivessem autonomia para pensar a eleição e criar estratégias para conquistar o eleitorado. Os cidadanistas não percebiam tentativas de cerceamento ou de controle de suas iniciativas, a não ser pela recomendação reiterada para que priorizassem alguns eventos que, na avaliação da coordenação, teriam o potencial de converter mais votos, mas ainda assim sempre demonstraram estar convencidos dessa importância. Segundo a recomendação do próprio coordenador Ivan, em uma das reuniões de campanha em Ermelino Matarazzo: a gente vai fazendo, o negócio é perder o controle.

Embora o Mandato fosse, em vários aspectos, a continuidade da Raiz, houve um elemento que, mesmo não sendo propriamente novo, marcou profundamente a campanha e passou a modificar marcadamente o campo de atuação da Raiz. Trata-se da aproximação do coletivo com setores de base da igreja católica, de onde provieram alguns dos integrantes da chapa do Mandato. Mesmo que já houvesse a relação de integrantes com a igreja, essa relação ainda não havia assumido a importância coletiva que teve com organização do MC. A proximidade de Turino com os chamados setores progressistas ${ }^{27}$ da igreja e, principalmente, com o papa Francisco, parece ter contribuído decisivamente para essa aproximação. Em uma conversa com integrantes da juventude católica de Itaquera ficou claro que a sua concepção positiva do Mandato se devia, de forma relevante, à associação da imagem do Célio com a do papa. Os cidadanistas sempre consideraram

27 A ideia de movimentos (correntes, igrejas etc.) progressistas tem sido cada vez mais presente nas autodenominações de iniciativas identificadas com o campo político da esquerda no Brasil. Embora haja variações nos significados atribuídos ao termo progressista, eles apontam para o alinhamento com bandeiras comumente defendidas pela esquerda, como a luta contra o preconceito e a desigualdade social, a defesa das liberdades civis, a crítica ao capitalismo, entre outros. 
essa associação um trunfo para angariar o apoio do eleitorado e um dos impressos de campanha mais solicitados para a distribuição era a Folha Cidadanista, mais especificamente, a edição com a reportagem de capa tratando do encontro do Célio com o papa em Roma e com uma foto do encontro em destaque. De fato, nas ações de distribuição de material vi que a recepção do jornal era muito maior do que a aceitação de outros impressos, aliás, muitas vezes as pessoas vinham até nós solicitar o jornal. Acredito que a razão para isso é, principalmente, o formato do material, já que um jornal não é geralmente visto de longe como um material de campanha política. Entretanto, conversei com algumas pessoas que estavam lendo o material nas filas dos pontos de ônibus do terminal Itaquera e entre dezesseis leitores interpelados (escolhidos por parecerem compenetrados na leitura), sete apontaram o título e a foto com a figura do papa como elementos que despertaram o interesse pela leitura. Vale mencionar o fato de que entre esses leitores cinco eram católicos e tinham uma imagem extremamente positiva do papa Francisco enquanto um era evangélico e outro sem religião, mas ambos também declararam nutrir simpatia pela figura do papa. $O$ grau de aceitação do jornal pelos católicos era realmente impressionante e essa receptividade parece ter sido muito bem aproveitada com a distribuição do impresso na saída das missas e atividades realizadas nos espaços sociais das igrejas.

A participação de católicos no Mandato coincidiu com certo reavivamento de setores de base da igreja que vem acontecendo após o início do papado de Bergoglio, um fenômeno que necessita ser mais bem explorado. Os membros católicos do Mandato utilizavam com mais frequência os termos igreja progressista para se referirem às instâncias de base da igreja que, historicamente, têm sido fortemente influenciadas pela Teologia da Libertação, ${ }^{28}$ como as Comunidades Eclesiais de Base (CEB). No primeiro diagrama do Mandato, por exemplo, o codeputado Eduardo Brasileiro, da Paróquia Nossa Senhora do Carmo, em Itaquera, foi identificado como representante das Comunidades Eclesiais de Base ao passo que nas publicações mais tardias passou a ser referido como representante da Igreja Progressista, uma opção bem mais inclusiva que permite abarcar, por exemplo, igrejas evangélicas ${ }^{29}$. O termo progressista também tem um alcance mais geral e nos discursos normalmente era associado à defesa de políticas de inclusão e desenvolvimento social,

28 A Teologia da Libertação é uma corrente teológica cristã nascida na América Latina, na década de 1970, e que, grosso modo, defende que a igreja deve atuar, preferencialmente, junto aos mais pobres, seguindo preceitos básicos do evangelho e que, para tal, as análises das ciências humanas e sociais sobre as causas da pobreza e desigualdade são ferramenta importante para a luta contra a desigualdade (DUSSEL 1999).

29 A falta de diálogo com as igrejas evangélicas era continuamente apontada como uma das principais deficiências do Mandato, principalmente em razão da aproximação dos evangélicos com candidaturas da direita conservadora, principalmente a de Jair Bolsonaro. 
bem como à liberalização dos costumes, pautas comumente defendidas pela esquerda. De modo geral, os cidadanistas católicos se mostravam favoráveis a pautas polêmicas - normalmente rechaçadas pela maioria dos cristãos - como a descriminalização do aborto e a descriminalização ou liberação da maconha para uso medicinal ou mesmo recreativo. Parece razoável defender que o ingresso dessas pessoas no Mandato poderia muito bem ser pensado em termos do conceito afinidades eletivas ou nas palavras da Rafaela, em termos que caminhos paralelos que se cruzaram ou que se encontraram para a construção conjunta de novos caminhos. A Rafaela, o Eduardo e seus companheiros de fé já atuavam ativamente nas comunidades de suas paróquias muito antes de constituírem o Mandato e prosseguiram com seus ativismos após as eleições. Mas tudo leva a crer que o Mandato ampliou, de modo decisivo, os objetos e o significado político de suas atuações. Assim podem ser pensadas, por exemplo, as iniciativas pós-eleitorais da Rafaela para promover, no salão social da paróquia de São Francisco de Assis, encontros de discussão e formação política que versavam sobre diversos temas (como mandatos coletivos, por exemplo), encontros que procuravam diluir as barreiras que, por muito tempo, têm separado a ação comunitária da política institucional. Mais do que aprender sobre mandatos coletivos, essas reuniões discutiam a viabilidade de uma candidatura coletiva e comunitária ou o apoio a candidaturas de ativistas da comunidade para o pleito municipal seguinte. É importante lembrar que, em sentido estrito, esses encontros não faziam parte nem das atividades do Mandato Cidadanista (que terminou alguns meses depois do fim das eleições), nem tampouco da Raiz, mas eram ações autônomas da Rafaela (e outros) que nem sequer chegou a se filiar à Raiz. Entretanto, nas discussões pós-eleitorais da Raiz, ela era vista como integrante natural do coletivo para as próximas eleições, tendo sido mencionada, inclusive, como uma das possibilidades para ser a candidata oficial da Raiz à câmara. Por isso tenho insistido nas limitações da noção clássica de grupo para entender essas formas de fazer política e privilegiado o modo como os agentes efetivamente atuavam e o que faziam com essa noção. Nunca vi avaliarem a pertinência ou não da candidatura da Rafaela ou da Thaynah para as eleições seguintes em termos de filiação à Raiz, aliás, elas estiveram entre os nomes mais citados quando falavam sobre possibilidades para uma provável candidatura do coletivo em 2022, à frente da maioria dos filiados. Havia, sem dúvida, um senso de pertencimento a uma coletividade (que ia muito além da ideia de um arranjo temporário para disputar uma eleição), mas ele era mais o resultado de um 'fazer-junto' do que de um cadastro formal, registrado em uma lista ou banco de dados. Por isso não me parece meramente acidental que nas últimas atividades do meu campo, nas quais assumi um papel menos 
observante e mais participante, alguns cidadanistas me incluíram nas falas como um dos integrantes da Raiz, mesmo que já lhes estivesse claro que eu estava ali como pesquisador.

É importante deixar claro que a presença da igreja no Mandato não se deveu unicamente ao ativismo dos cidadanistas católicos de Ermelino e Itaquera. As paróquias São Francisco de Assis, em Ermelino Matarazzo, e Nossa Senhora do Carmo, em Itaquera, sempre se destacaram pelo seu engajamento na luta social, tanto por parte dos grupos de jovens e pastorais, quanto por parte dos padres Ticão e Paulo. Em Ermelino Matarazzo, desde a adolescência tenho acompanhado a atuação do Padre Ticão em diversas causas que vão, desde a promoção de rodas de conversa sobre política e tratamentos de saúde alternativos, até a organização de mobilizações por mais universidades e equipamentos públicos na região. Críticos ao clericalismo dominante na igreja e de sua inércia diante da dura realidade social que aflige os mais pobres, seis padres da zona leste de São Paulo, entre os quais, Padre Paulo e Padre Ticão, fundaram, em 2010, o coletivo Igreja Povo de Deus em Movimento (IPDM) que reuniu paróquias, religiosos, comunidades e cidadãos, em torno da luta por transformação social e por direitos sociais básicos como educação, saúde, moradia e emprego. Em muitos sentidos, o IPDM constituiu uma retomada da Teologia da Libertação e uma revalorização do papel das Comunidades Eclesiais de Base (CEBs) na zona leste de São Paulo, buscando, tanto atuar diretamente em ações sociais, como realizar discussões e atividades de formação política. Os movimentos existentes no interior das paróquias da zona leste, sobretudo os grupos de jovens de onde provieram os integrantes do Mandato, têm, direta ou indiretamente, sido revigorados e transformados por essa nova onda de ativismo social, que, de certo modo, recebeu grande impulso com o repúdio a inúmeras medidas adotadas pelo governo recém-eleito. Fica então claro que as configurações e dinâmicas do Mandato Cidadanista e da Raiz dependiam de múltiplas modalidades de relações entre sujeitos e entre coletivos. Mais do que vasos comunicantes entre coletivos, havia inúmeras formas de composições, ressonâncias e contaminações de todo tipo, bem como fusões e interpenetrações, até que, de repente, um movimento já era outro e não era possível saber exatamente como discerni-los - preocupação que, muitas vezes, nem mesmo fazia sentido do ponto de vista dos agentes envolvidos. O mesmo vale para a ideia supracitada de retomada da Teologia da Libertação (TL). Na perspectiva de alguns desses agentes (como o Padre Ticão) a Teologia da Libertação sempre foi uma fonte de inspiração para sua atuação, nunca esteve morta ou em decadência como se tem afirmado frequentemente (RIBEIRO 2010) e como a ideia de retomada pode dar a entender. É muito difícil analisar o pensamento social da igreja (mesmo aquele que, a princípio, não reivindica fazer parte da Teologia da Libertação) sem reconhecer relação direta ou 
alguma influência da TL e bastaria uma conversa com qualquer padre ou liderança religiosa dessas paróquias para que isso fosse logo confirmado.

\subsection{Uma campanha cidadanista}

No final do mês de agosto foi realizado o lançamento oficial da campanha do Mandato Cidadanista, no Teatro Comune, no centro de São Paulo. Nunca é demais afirmar que esses eventos oficiais podem ser momentos privilegiados para apreender os significados e as práticas que conformam os modos de fazer política dos sujeitos, contrariando a visão de que esses eventos possuiriam importância secundária em razão do fato de terem sido minuciosamente planejados e preparados e que, por isso, esconderiam uma suposta verdade das relações sociais que só a espontaneidade das práticas cotidianas poderia revelar. $\mathrm{Na}$ verdade, a relação desse eventos mais formais com as atividades ordinárias da campanha se deu sob diversas modalidades e podemos dizer que, muitas vezes, os primeiros desvelariam ou apresentariam em modo ampliado aspectos das relações sociais que eram pouco visíveis ou apenas vagamente sugeridos nas práticas e discursos cotidianos. De certa forma, o lançamento de campanha tanto ampliou, quanto antecipou, complementou, modulou e até mesmo inverteu as formas e dinâmicas presentes nas ações realizadas nas ruas, feiras, parques, terminais de ônibus e paróquias. E mesmo o que o evento silenciou em relação a aspectos fundamentais da realidade eleitoral pode se mostrar bastante revelador para o entendimento dessas práticas.

Já passava das sete da noite quando adentrei a área social em frente à entrada do teatro, onde se encontravam aproximadamente quinze pessoas, distribuídas em pequenas rodas de conversa, e mais outras três desacompanhadas, caminhando e observando alguns cartazes e decoração do local. Assim que cheguei, comecei a saudar os presentes com os quais ia estabelecendo contato visual e fui em busca dos cidadanistas que eu já conhecia para cumprimentá-los e para ser apresentado aos seus companheiros. Depois de algumas apresentações, mais ou menos meia hora depois, entrei no teatro, onde alguns já estavam sentados, e me sentei na última fileira em que havia pessoas sentadas, à direita. Pouco antes das oito horas, o codeputado e ativista socioambiental Thomás Enlazador fez a abertura do evento saudando os quase sessenta presentes até aquele momento e pedindo para que compartilhassem em suas redes o link da transmissão ao vivo. Logo de início, Thomás falou do princípio do Bem Viver (Tekó Porã, em Guarani), segundo ele, uma contribuição 
dos povos tradicionais para o Mandato, mostrando a continuidade do projeto do Mandato Cidadanista com os princípios fundadores da Raiz. Em seguida a codeputada indígena e educadora Cristine Takuá entoou um canto Guarani. Era muito perceptível nesse momento a compenetração dos presentes e a emoção provocada pela vocalização profunda de Cristine, acompanhada da rítmica de seu maracá, emoção que eu mesmo experimentei e que, ao final, se traduziu em palmas calorosas e em um breve comentário de um espectador que sentava ao meu lado sobre a sua sensação corpórea (fiquei arrepiado) com a performance. Conversando depois com dois dos espectadores ficou muito patente a interpretação do canto com uma reza de lamento ou de exortação a entidades espirituais, associando-o com a necessidade de força para lutar contra a destruição do nosso mundo. Mais importante do que perceber certas convergências na interpretação do rito - que, sem dúvida, mereceria um exame mais detalhado - foi constatar que se tratou de um momento de profunda absorção emocional coletiva. Momentos como esse, em que emoções são experimentadas coletivamente, podem, sem dúvida, fortalecer o senso de pertencimento a uma coletividade, mas nesse caso, parece ter feito mais do que isso. Esse ritual e outras ações pós-campanha sugeriram que, entre os cidadanistas, as emoções não eram apenas um meio para fins que lhes seriam exteriores, mas elas também se mostravam, ao mesmo tempo, meios e fins. Assim, além das emoções terem sido acionadas em prol do sentido de coletividade, o coletivo também parece ter sido mobilizado para o cultivo e a gestão das emoções, de modo que podemos falar em uma coletividade emocional ou afetiva. Estamos falando de um 'sentir-junto', ou seja, um modo de fazer política que, visando a superar as práticas políticas que sempre reivindicaram a separação entre razão e emoção, buscava emocionar a política para reencantá-la. Como vimos no capítulo 1, a própria concepção de esquerda e de (ecos)socialismo dos cidadanistas supunha o desenvolvimento de uma sensibilidade para com o sofrimento dos socialmente excluídos e de outras formas de vida.

Depois da apresentação da música Todo amor que houver nessa vida, cantada a capella pelo cidadanista e cantor André, com participação da plateia, Ivan assumiu o microfone e chamou às falas o convidado e candidato a deputado estadual Toninho Vespoli, que fez um balanço dos aspectos positivos e negativos dos governos do Partido dos Trabalhadores na presidência e sobre as conquistas do seu partido, o PSOL, em São Paulo. Ao falar da importância da candidatura do Célio para o PSOL, Toninho destacou a nova forma de se organizar que o Célio levou para o PSOL e para o campo progressista. A fala de Vespoli retomou uma ideia muito persistente entre os cidadanistas, sobretudo após as eleições, que foi decisiva para aproximação da Raiz com o PSOL e para minar a resistência daqueles que, a princípio, se lhe opunham. Trata-se da ideia de que, caso a Raiz 
ingressasse no PSOL, ela não seria apenas mais um movimento dentre tantos outros que estavam abrigados no partido, mas o projeto cidadanista teria um grande potencial de transformar a legenda. É como se a proposta da Raiz tivesse uma capacidade ímpar de responder aos anseios daqueles que em 2013 clamaram por um novo modo de fazer política e que isso seria reconhecido tão logo começassem mostrar suas ideias e seu modo de fazer política dentro do partido. Havia, sobretudo, a visão de que o projeto da Raiz teria a capacidade de conquistar as pessoas por sua filosofia e por sua poética intrínseca. Por isso os cidadanistas não falavam em ingressar no PSOL para convencer os psolistas a aderirem a Raiz, a ideia era, antes de tudo, encantar, como se, ao conhecerem a proposta da Raiz, a tendência fosse logo serem conquistados pela beleza e profundidade filosófica contida nos seus princípios e nas suas ideias. Daí a importância, para o coletivo, em ser visto, ser conhecido e marcar presença, se possível, vestindo suas camisetas, segurando suas faixas e portando suas bandeiras. Claro que nas ações de campanha todos sabiam que era preciso atuar no sentido de argumentar e convencer o eleitorado de que o Mandato deveria ser escolhido por ser um diferencial positivo em relação a outras candidaturas. Ainda assim, era muito forte a ideia de que, se as pessoas tivessem a oportunidade de entender o que era o Mandato, seus princípios e sua concepção inovadora do fazer político, elas provavelmente se encantariam e abraçariam facilmente a proposta. Em muitos momentos, nas atividades de campanha, era fácil perceber essa tensão entre o pragmatismo eleitoral (maximizador de votos) e as formas de apresentação de um novo modo de pensar a política, o que é, em larga medida, a contradição entre as exigências do tempo da política e a temporalidade das relações socioafetivas autênticas e da conversa interessada. Assim, entre a necessidade de distribuir impressos e pedir votos para a maior quantidade possível de eleitores e o desejo de conversar com as pessoas e convidá-las a ler, entrar no site e aderir às ideias do Mandato, muitas vezes se buscou um meio-termo como a panfletagem qualificada (em que se priorizava a distribuição dos impressos para as pessoas que pareciam ter maior interesse em recebê-los e se mostravam mais abertos ao diálogo) e a promoção de rodas de conversa com a comunidade. Por outro lado, não foram raras às vezes que ouvi as pessoas dizerem, inclusive alguns cidadanistas, que o Mandato Cidadanista apresentava uma proposta política muito bonita, mas que era muito filosófica, no sentido de lhe faltar objetividade e aplicação prática, apesar da chapa ter apresentado um programa eleitoral contendo propostas concretas de políticas públicas, incluindo, em alguns casos, a indicação da fonte de recursos do orçamento para sua implementação.

Após o discurso de Toninho, Ivan agradeceu e falou brevemente sobre a experiência do Célio Turino de 40 anos na gestão pública e da sua iniciativa de trazer as ideias e as pessoas da Raiz 
para a sua candidatura e, logo em seguida, convidou-o para assumir o microfone. Célio iniciou a sua fala com seu tom muito característico: em ritmo calmo e volume baixo, mas sempre muito bem audível e articulado. Ele começou falando a respeito do Cidadanismo, conceito central nos discursos e práticas do coletivo, que, segundo ele, foi inspirado na ação da cidadania, com o protagonismo da sociedade. Disse que o conceito era também uma homenagem ao sociólogo Herbert de Souza, o Betinho, ativista que teve a vida dedicada à luta em favor dos pobres e dos direitos humanos, falecido em 1997. Célio prosseguiu dizendo que é a sociedade quem deve tomar o poder e que, portanto, a representação política precisa ter humildade e aprender a escutá-la. Seria preciso saber mandar, mas mandar obedecendo (repetindo o princípio zapatista), servir. Propôs uma revolução brasileira que vai à alma do povo brasileiro, que vai à raiz, e mencionou os três princípios da Raiz (Tekó Porã ou Bem Viver, Ubuntu e Ecossocialismo) como um caminho nessa direção. Parece-me importante aqui chamar a atenção para uma concepção (mencionada no cap.1) bastante presente no coletivo de que haveria uma essência no povo brasileiro que, de alguma forma, foi esquecida ou sufocada pela tirania dos governos (em especial a ditadura militar) e pela lógica perversa do neoliberalismo e que os princípios do cidadanismo contribuiriam para o resgate dessa essência (quase) perdida. Em algumas reuniões, durante e depois da campanha, me deparei com uma variante desse essencialismo em algumas falas em que o caipira era retratado como cordial, acolhedor e portador de valores que o morador das grandes cidades teria deixado para trás e que deveriam ser resgatados, como a simplicidade, a honestidade, o espírito comunitário etc.

Por último, Turino apresentou as suas principais propostas e bandeiras, algumas já defendidas em sua trajetória pregressa como ativista, embora tenham sido atualizadas a partir da conjuntura daquele momento e das discussões coletivas; outras, foram o resultado de construção colaborativa com os demais cidadanistas e tinham como objetivo oferecer soluções para alguns dos mais graves problemas gerados pela crise e, ao mesmo tempo, promover os princípios políticos do coletivo.

1. Redução de 50\% do custo parlamentar: segundo Turino, a sua proposta de redução no orçamento e número de parlamentares não resultaria em diminuição da representatividade, caso fossem realizadas mais consultas diretas à população, como propôs. Em sua fala, o candidato não deu mais detalhes sobre a proposta que consistiria em uma redução gradual de $10 \%$ ao ano do gasto com parlamentar até atingir o gasto médio mundial. Segundo o material de campanha, no ano de 2022 essa medida economizaria anualmente aproximadamente R $\$ 7$ bilhões. Além disso, sua proposta 
previa a redução da câmara federal, de 513 para 380 deputados, e do senado, de três senadores para dois por estado.

2. Programa Agentes Jovens da Comunidade: consistiria na concessão de uma bolsa para jovens pobres. Turino defendeu que o projeto estava embasado em estudos e que parte do valor gasto na intervenção realizada no Rio de janeiro daria para pagar bolsas para 100 mil jovens por um ano. O material impresso e o site oficial da campanha <www.mandatocidadanista.com.br $>$ detalharam mais a proposta que previa o financiamento de entidades da sociedade civil (comunitárias) para o desenvolvimento de atividades de formação em cultura, meio ambiente e serviços comunitários, para jovens entre 16 e 24 anos e como alternativa ao atual serviço militar obrigatório. Seria concedida, durante o período de um ano, uma bolsa mensal de $\mathrm{R} \$ 600,00$ por uma carga horária de 20 horas semanais. A meta do projeto seria de um milhão de bolsas por ano.

3. Geração de emprego: a proposta do MC era utilizar um quarto das reservas internacionais para geração de empregos. De acordo com o material de campanha, há cálculos que apontariam que esse "Fundo Nacional de Trabalho" geraria cerca de 10 milhões de empregos.

4. Incluir na constituição os direitos da natureza: inspirado no conceito de Bem Viver, disse que, se eleito, iria trabalhar em um Projeto de Emenda Constitucional que teria como base a ideia de que o ser humano é apenas parte de uma comunidade da vida. Mencionou o sucesso de Paulo Búfalo (candidato a deputado Estadual de Campinas), ao conseguir o fim dos rodeios em Campinas e defendeu a proibição dos rodeios e das vaquejadas no país inteiro, argumentando que não deveria ser mais concebível que a nossa espécie pudesse se divertir com o sofrimento de outra. Turino deixou claro que não se tratava, no entanto, de acabar com o consumo de carne, mas de criar uma política de bem estar animal que proibisse, por exemplo, que uma ave fosse impedida de dormir com o uso de iluminação.

5. Célio também citou algumas bandeiras defendidas pelo Mandato Cidadanista como: políticas voltadas para crianças, jovens e LGBT's; a permissão para adoção de crianças por casais LGBT's; o fim da política do encarceramento em massa; tratamento da questão das drogas como política de saúde; a revogação da reforma trabalhista, da PEC do Teto dos Gastos Públicos e das nomeações para as agências reguladoras feitas no governo Temer. 
Antes de encerrar sua fala, Célio mencionou brevemente algumas parcerias em diversas áreas (permacultura, meio ambiente, LGBT) e agradeceu a todas e todos do coletivo, dizendo esperar fazer um rodízio com outr@ candidat@ depois de quatro anos. Ivan retomou a condução do evento informando que foram colhidas as assinaturas do Pacto Cidadanista - um documento contendo as assinaturas do Célio e d@s codeputad@s e que formalizava um compromisso com a sociedade e entre os próprios cidadanistas. Nesse momento, Ivan anunciou a apresentação, em um telão, de pequenos vídeos (com duração inferior a dois minutos) gravados para a campanha, sendo um vídeo para cada codeputad@, mas avisou que, por causa da correria, não teve tempo para gravarcom todos. Após cada vídeo,@ codeputad@retratad@era convidad@ a se sentar em uma das cadeiras colocadas no palco, organizadas em formato semicircular. Segue adiante a transcrição dos nove vídeos gravados que ainda se encontram disponíveis (18/08/2019) no canal Mandato Cidadanista, na plataforma de compartilhamento de vídeos YouTube.

O primeiro vídeo apresentado foi o da codeputada, especialista e defensora da agroecologia Ondalva Serrano.

A nossa população, seja do campo ou da cidade, merece e precisa de alimentação saudável que é oferecida pela agricultura orgânica. Infelizmente estão colocando veneno na nossa comida. Nós queremos plantar a vida e plantar a vida implica em podermos aproveitar, utilizar adequadamente as áreas urbanas, as áreas periurbanas e as áreas rurais que estão disponíveis para produzir esses alimentos orgânicos saudáveis para nutrir toda nossa população. Nós precisamos investir em políticas públicas comprometidas com a vida e a saúde da população. Políticas públicas que criem mecanismos e viabilização mesmo de recursos que invistam nessa produção local de alimentos, atendendo de forma saudável a população. Sou Ondalva Serrano, engenheira agrônoma. Estou junto com Célio para deputado federal no Mandato Cidadanista. Eu sou porque você é.

Fonte: $<$ https://www.youtube.com/watch?v=HClkP3sKSR4>

Terminado o vídeo, Ondalva foi convidada a falar. Ela disse que foi a sua primeira participação em organização política e que antes achava que o voto era o único meio de exercer a política. Para Ondalva, o Mandato Cidadanista foi uma verdadeira escola de formar cidadãos e agradeceu ao Mandato a oportunidade de ser aprendiz. Os presentes aplaudiram com entusiasmo. O vídeo seguinte foi do Eduardo Brasileiro, codeputado e ativista ligado à igreja Nossa Senhora do Carmo, em Itaquera. 
Ocupar as ruas. Gestar sonhos. Construir utopias. Esses são valores fundamentais para construir uma cidade de todos. A intolerância religiosa e política ela atinge diretamente as nossas comunidades. A prática de solidariedade vem se dissolvendo e a gente não consegue mais se unir e construir pontes para superar as nossas dificuldades. Queremos reunir as nossas comunidades de fé para construir a cultura do encontro. Esta que supera as nossas violências, as nossas dificuldades. Por isso, vamos articular políticas públicas inserindo nos nossos bairros, nas nossas comunidades, o que é necessário para construir uma cidade mais humana. Queremos articular comunidades que possam se engajar na construção da cultura do encontro, dos diálogos de cidadania que forjem nas nossas comunidade a esperança possível. Por isso, para construir uma cidade mais humana, precisamos articular políticas públicas em busca de justiça e de solidariedade. Sou Eduardo Brasileiro, nascido e criado em Itaquera, faço parte de um coletivo de igrejas e também trabalho na formação político pastoral da minha comunidade. Codeputado no Mandato Cidadanista com Célio Turino pelo Bem Viver, para assim juntos ocuparmos uma cadeira em Brasília. Eu sou porque você é. Queremos mudar nosso bairro com muito amor e fé.

Fonte: $<$ https://www.youtube.com/watch?v=oSmBiH_cG0A $>$

Após o término do vídeo, Eduardo foi à frente para falar. Defendeu que era preciso dizer que as comunidades eclesiais têm um projeto e que ele é libertador. Lamentou o modelo neoliberal que fala em termos do individual e falou da importância da comunidade e que o modelo de atuação dos cidadanistas tinha que ser circular, uma mandala onde todos se encontram. Enquanto era aplaudido, Eduardo se acomoda em uma das cadeiras e, nesse momento, o vídeo da codeputada Thaynah Gutierrez, ativista pela educação, de Ermelino Matarazzo, foi iniciado.

As nossas escolas, elas podem e devem ser espaços onde todos e todas aprendam a ser mestres dos seus próprios destinos. As nossas escolas públicas, elas foram construídas em um modelo autoritário que acaba não educando ninguém. Dá pra gente fazer melhor. A gente precisa propor soluções que façam com que nós jovens sejamos protagonistas de uma nova reforma no ensino e tudo isso acontece a partir de muito diálogo e debate com quem tá na ponta sendo ensinado por esse ensino que hoje não permite que os jovens entrem no ensino superior público, faz com que os jovens entrem em ensinos superiores que são afastados da nossa realidade, das nossas necessidades e isso impede que o jovem realize os seus sonhos que sequer o jovem tenha sonho. A gente precisa escutar mais, fazer com que as escolas sejam espaços onde as nossas vivências pessoais sejam ressaltadas ao invés de excluídas. A gente precisa mostrar que é por meio de nós jovens que a gente consegue fazer a transformação e, principalmente, que é através da educação que a gente consegue modificar todas essas realidades do país. Eu sou a Thainah, sou estudante de administração pública na Fundação Getúlio Vargas, sou bolsista e moradora da periferia da zona leste de São Paulo, em Ermelino Matarazzo. Estou com Célio Turino e com Mandato Cidadanista buscando uma cadeira como deputada federal para realmente fazer a mudança. 
Fonte: $<$ https://www.youtube.com/watch?v=HH9JRfKO77M $>$

Após o vídeo, Thaynah foi chamada às falas. Ela falou que o pobre é incluído até certo limite e que era preciso estar presente no legislativo. Em seguida, lamentou a postura reacionária e a atuação dos evangélicos neopentecostais, sem entrar em detalhes sobre o caráter de sua reprovação, uma vez que as razões costumavam ser sempre objeto de comentários e discussões. Após a sequência de aplausos e sua acomodação no semicírculo de codeputad@s sentad@s, foi iniciado o vídeo de Rafaela Guabiraba, codeputada e ativista ligada à Paróquia São Francisco de Assis, localizada na sua comunidade de residência e atuação, em Ermelino Matarazzo.

As políticas públicas nunca incluíram as periferias da cidade. Nós não queremos migalhas, mas as mesmas oportunidades. Merecemos viver em uma São Paulo onde tenhamos uma cultura de paz. As nossas periferias são carentes de políticas. Nós não queremos migalhas, mas as mesmas oportunidades. É hora de agir aqui e agora. É justamente através da nossa participação dentro da política que podemos transformar outras sociedades possíveis. Uma sociedade mais justa, mais fraterna e mais digna, onde todos e todas tenham qualidade de vida na moradia, na saúde, na educação, na segurança... É preciso coragem e quando a coragem se junta com a capacidade de se indignar, a esperança brota novamente. Sou Rafaela Guabiraba, atuo na paróquia São Francisco de Assis, em Ermelino Matarazzo, periferia de São Paulo. Sou codeputada e estou com Célio Turino a uma cadeira de deputado federal em Brasília, a serviço do bem comum. Eu sou porque você é e queremos exercer o direito à cidade com fé e amor. Fonte: $<$ https://www.youtube.com/watch?v=RxB nY2QY5g $>$

Em seu breve comentário após o vídeo, Rafaela falou sobre o reencantamento pela política que o Mandato Cidadanista trouxe de volta e agradeceu ao mestre Célio Turino. O vídeo seguinte foi do codeputado Thomaz Enlazador, permacultor e ativista ambiental.

Juntos somos mais fortes. Trabalhamos por um Brasil do Bem Viver, um Brasil que respeite os direitos da natureza. Ao longo dos últimos vinte anos o Brasil e o estado de São Paulo sofreu uma série de retrocessos na área ambiental: desflorestamento, crise hídrica, desertificação, agrotóxicos, alimentação contaminada, mudanças climáticas, não dá mais. A proposta é a criação de políticas públicas inspiradas no Bem Viver, inspiradas e implementadas com o lastro dos direitos da Mãe Terra, como a permacultura popular, agroecologia para todos, uma alimentação nas escolas sem veneno, a economia solidária, as ecovilas como instrumento de assentamentos humanos sustentáveis. Sou Thomaz Enlazador, permacultor social, mestre em políticas e gestão ambiental e to militando há 20 anos na área. Sou codeputado pelo Mandato Cidadanista junto com Célio Turino a uma vaga para ocuparmos o congresso nacional. Se não nós, quem? Se não agora, quando? Fonte: $<$ https://www.youtube.com/watch?v=HA7BiPxP8EU $>$ 
Thomaz assumiu o microfone e disse que o trampo é muito desafiador. Falou da necessidade da conexão com os povos ancestrais e da defesa de pautas urgentes: a reforma agrária, a conversão de desertos verdes em agroflorestas, a discriminalização da cannabis e a criação de hortas orgânicas em toda a cidade. Terminou sua apresentação com a conhecida frase da filosofia ubuntu, tão cara aos cidadanistas: eu sou porque nós somos!

Em seguida foi a vez da codeputada Surya Guimaraens realizar o seu discurso, já que não tinha vídeo gravado. Surya militava na cidade de Campinas, onde residia, e sua atuação era em favor da igualdade de gênero. A codeputada contou que entrou para a política em 2016 quando foi candidata à prefeita de Campinas. Em seguida disse que, assim que surgiu a ideia da candidatura coletiva, foi convidada pelo Célio para compor o Mandato Cidadanista. Depois encerrou a sua intervenção falando sobre a desigualdade de gênero ainda muito persistente na sociedade. Falou sobre as dificuldades das mães conseguirem emprego e sobre a necessidade das mulheres se reafirmarem o tempo todo enquanto os homens não precisam.

Logo após a Surya acomodar-se em uma cadeira, a sua colega de Campinas, a codeputada Deise Mara, também sem vídeo gravado, fez a sua breve apresentação. Deise era Jornalista e trabalhou por muitos anos em projetos ambientais. Ela encerrou a sua fala dizendo que as estruturas políticas tradicionais estavam ruindo e que havia a necessidade de um novo modelo.

A última cidadanista sem vídeo gravado, a codeputada indígena Cristine Takuá, deu início a sua apresentação, sempre muito eloquente. Cristine se apresentou como educadora e pensadora com formação em filosofia. A codeputada disse que, por onde passava, sempre insistia na ideia de dar voz para os que não falam. Segundo ela, era preciso dar ouvido às vozes do silêncio da floresta onde há seres que pensam como nós. Agradeceu à força dos espíritos sagrados da floresta e a seu companheiro, um líder espiritual, que estava ausente. E terminou sua apresentação citando os versos popularizados por Raul Seixas: sonho que se sonha só é só um sonho e sonho que se sonha junto é realidade. Depois foi a vez do curta do codeputado Magno Oliveira, representante de Poá e Alto Tietê.

Ser jovem é ter fé na vida, fé no amor e fé no que virá, como cantava Gonzaguinha. Estamos cansados de sermos abandonados pelos políticos sempre após as eleições. Não vemos possibilidade de solução para os principais problemas que nos afetam como saúde, segurança, educação, cultura e esporte. Por meio do Mandato Cidadanista solucionaremos este problema porque o povo participará ativamente das tomadas de decisões, das elaborações de projetos, poderá, por exemplo, decidir como ser utilizada emenda 
parlamentar, por meio de audiência pública onde será consultado e mais: poderá propor onde ser utilizado esse recurso. O Mandato Cidadanista será o povo em Brasília. Eu sou Magno Oliveira, codeputado por Poá e Alto Tietê e estou com Célio Turino para deputado federal.

Fonte: $<$ https://www.youtube.com/watch?v=LmbINFKZ33k $>$

Após o vídeo, Magno dirigiu-se ao palco e começou a improvisar um jingle de campanha no microfone. Disse que se perdeu no caminho para o evento e que andou muito para chegar, por isso se atrasou. Falou que estava no Mandato para fazer política para o povo e com o povo. Para isso, lembrou da importância da plataforma Rios e da proposta de encontros semestrais do Célio Turino com suas bases. Por último, afirmou que poderia sentar com políticos para construir uma política pública, mas que não iria se sentar com malfeitores.

A seguir, foram apresentados, em sequência, os vídeos de Aluizio Marino, Baby Amorim e Dennis Oliveira, que não estavam presentes no evento. O codeputado Aluisio Marino era ativista e pesquisador nos temas de cultura digital, urbanismo e ocupações culturais.

Existe uma efervescente produção na cidade: uma produção comum, seja no âmbito da cultura, seja no âmbito de um urbanismo humano, seja no âmbito da redução de danos, do trabalho com as populações vulneráveis. E como que a gente pode fortalecer essa produção comum, como que a gente pode aproveitar essa riqueza e potencializar ainda mais essas experiências, essa é uma das propostas do Mandato Cidadanista: de fortalecer e de reconhecer ocupações culturais, grupos antiproibicionistas, experiências de participação social diferentes que ampliam a participação do sujeito para além do voto e sim para possibilidade concreta de transformação da realidade. Me chamo Aluizio, sou pesquisador nas áreas da cultura digital e do urbanismo humano, estou compondo a proposta do Mandato Cidadanista com Célio Turino e uma galera muito massa pra disputar essa espaço como deputado federal, vamos juntos ocupá-lo. Fonte: $<$ https://www.youtube.com/watch?v=unzV8wDPW6c $>$

Baby Amorim tinha larga experiência em gestão cultural e contribuiria, caso o Mandato fosse eleito, com a implementação da política dos pontos de cultura, permitindo que a gestão cultural fosse feita a partir da auto-organização dos próprios agentes culturais das comunidades.

Eu gostaria que um dia a cultura realmente fosse valorizada como ela merece ser. Cultura é transformação, cultura é alimento pra alma. Eu acredito que temos que repensar as políticas culturais, programas que realmente estimulem essa produção cultural do país. O programa Cultura Viva, ele chega desescondendo o Brasil, desescondendo a cultura brasileira. Então a gente vê fomentos indo para aldeias indígenas, quilombos, desescondeu toda essa gama de trabalhos culturais do nosso país, de norte a sul. 
Sou Baby Amorim, sou codeputada do Mandato Cidadanista, estou junto com Célio Turino para uma vaga para deputado federal.

Fonte: $<$ https://www.youtube.com/watch?v=yt_OZAMgb7s $>$

Por último, foi apresentado o vídeo gravado com o codeputado Dennis Oliveira, professor de jornalismo na USP e militante da Rede Antirracista Quilombação ${ }^{30}$.

Você jovem negra, negro da periferia, quer viver em paz e ser feliz, hoje infelizmente isso não é possível, na periferia você enfrenta todo tipo de violência que vem das forças policiais, vem da ausência de oportunidades e para isso o Mandato Cidadanista de Célio Turino tem uma proposta muito importante que é a construção do projeto agente jovem que é nada mais do que você criar uma linha de fomento específica para financiar jovens da periferia a executarem projetos e ações culturais nas suas localidades. Há recursos pra isso, basta apenas cortar todas as mordomias, todos os penduricalhos dos grandes cargos comissionados do executivo, legislativo e judiciário, que você tem recursos suficientes para bancar um universo grande de jovens da periferia que poderão assim desenvolver projetos sociais, projetos culturais nessas localidades. Esse é um projeto necessário, um projeto lógico, um projeto importante para enfrentar a violência que a juventude enfrenta na periferia. Sou Denis de Oliveira, professor de jornalismo na USP e militante da rede antiracista quilombação. Sou codeputado no mandato cidadanista de Célio Turino em busca de uma vaga pra deputado Federal.

Fonte: $<$ https://www.youtube.com/watch?v=adPxS6HJ4dg $>$

Thomaz retomou o microfone e convidou às falas o Juninho, candidato a deputado estadual pelo PSOL. O convidado falou de uma estrutura criada pela burguesia para dificultar pessoas de origem popular de conquistarem espaço na política. Juninho era conhecido pela luta pela aprovação da Lei Griô ${ }^{31}$ (o termo griô é resultado do aportuguesamento do francês griot) que, segundo ele, buscava o reconhecimento da ação dos mais velhos. Após os aplausos do público, Thomaz convidou o Célio para se sentar em uma cadeira junto aos demais e o Gabriel, animado como de costume, dirigiu-se à frente e pegou o microfone. Brincou, dizendo ser um bobo da corte e falou, com entusiasmo, para nunca pararem de sonhar, dando como exemplo os republicanos e abolicionistas que, alguns séculos atrás, eram vistos como loucos.

30 Blog da Rede Antirracista Quilombação fica no endereço <https://quilombacao.wordpress.com>. De acordo com o blog: "Quilombação é um coletivo de ativistas antirracistas lançado no dia 14 de dezembro de 2013 no Encontro Clóvis Moura de Ativistas contra o Genocídio da População Negra".

31 "A Lei Griô tem como missão instituir uma política nacional de transmissão dos saberes e fazeres de tradição oral, em diálogo com a educação formal, para promover o fortalecimento da identidade e ancestralidade do povo brasileiro". Fonte: <http://www.leigrionacional.org.br/ >. 
Com a abertura do encontro às perguntas e comentários da plateia, um membro do Partido Pirata declarou o seu apoio pessoal à candidatura do Mandato (já que não podia falar em nome do partido). Disse que o mandato pirata se baseava no conceito de mandato coletivo. A primeira pergunta foi sobre a situação do movimento da Raiz e qual seria a sua relação com o Mandato. Depois perguntou sobre a posição do coletivo em relação à privacidade de dados e se dispôs a contribuir com propostas nessa área. Célio retomou a palavra e citou as outras candidaturas do PSOL, a da professora Lisete, candidata à governadora, do Boulos, com seu sacerdócio na luta dos sem-teto e da Sonia Guajajara, que seria a cara do povo originário. Lembrou da boa relação do coletivo com o Partido Pirata e de um encontro realizado em 2010. Após esse comentário, o Ivan se dirigiu ao palco e falou sobre a Raiz. Disse que ela estava em processo de reconstrução, mas que os cidadanistas encerraram a coleta de assinaturas para a institucionalização do coletivo como partido político. E encerrou com uma declaração que, apesar de talvez ter trazido mais dúvidas do que esclarecimento para o colega pirata, foi, sem dúvida, uma grande pista em relação ao caminho que a Raiz iria seguir depois da eleição: A Raiz não está oficialmente no PSOL. Ela está onde deve estar, inclusive no PSOL.

O encontro foi encerrado com a leitura do manifesto de lançamento da candidatura do Mandato Cidadanista, realizada pelo autor, o poeta Hamilton Faria. Em seguida, Gabriel pede para falar e começa a cantarolar o principal jingle da campanha, uma paródia de dois versos da música Andar com Fé, do Gilberto Gil: Votar com fé eu vou, o Brasil precisa mudar. Depois, chamou os que estavam na plateia para tirarem fotos e os que permaneciam no teatro foram, aos poucos, acomodando-se na frente, todos bem juntos para caberem nas fotos e em ritmo descontraído, enquanto tocava, ao fundo, uma canção leve e alegre do cantor Flávio Venturini.

\subsection{Fazendo campanha}

No começo da campanha, a impossibilidade de estar presente em todas as atividades fez com que eu olhasse para o meu material e enxergasse nele uma série de lacunas que só poderiam ser preenchidas com um trabalho de campo mais ampliado e sistemático. No entanto, depois de acompanhar atividades no centro da cidade e nos bairros, percebi que minha sensação de incompletude se devia à premissa muito enraizada na disciplina de que, em qualquer realidade social, existe um todo que pode ser reconstituído (quase) em sua plenitude por um trabalho de 
campo bem realizado em cada uma das suas supostas partes. Logo vi, ao acompanhar as atividades dos cidadanistas da região central da cidade (e depois da zona leste), que eu estava lidando, não com um fragmento que apontava para um nível de inteligibilidade maior, mas com um todo, por direito próprio, que não necessitava de uma pesquisa complementar em outros pontos da cidade para ser entendido. Assim, por exemplo, as dinâmicas e conflitos do Mandato Cidadanista (o suposto todo) manifestavam-se em cada um dos seus segmentos regionais (partes). Por isso optei por focar a pesquisa de campo na região leste de São Paulo, onde eu tinha maior facilidade de acesso, e no centro da cidade, região onde aconteceram os eventos de campanha considerados mais importantes. Além disso, a zona leste é uma região que acabou assumindo proeminência naturalmente, em virtude dos ativismos dos integrantes do coletivo, com destaque para aqueles ligados à igreja.

A autonomia dos cidadanistas para planejarem e executarem ações de campanha foi ao encontro da necessidade de se fazerem presentes em vários lugares e de manterem uma agenda de atividades intensa, como seria o esperado em uma campanha eleitoral. Por outro lado, uma campanha baseada, em sua maior parte, na ação voluntária dos envolvidos, ficava dependente da disponibilidade de tempo dos voluntários e do seu comprometimento, algo de difícil mensuração. A noção de comprometimento do coletivo era aplicada diferencialmente, de forma mais ou menos individualizada e acionada para avaliar a atuação dos agentes, de maneira que uma pessoa que tivesse participado de três ações de campanha em uma semana e uma que tivesse atuado em seis atividades poderiam ser ambas consideradas, de modo geral, como igualmente comprometidas. Cidadanistas com muitos compromissos pessoais (como aqueles relacionados ao trabalho, filhos e família) que não tinham participação tão frequente, se comparados aos demais, eram normalmente incluídos nos discursos como aqueles que se comprometeram com o Mandato. Apenas de um modo bastante impreciso o comprometimento individual admitia alguma comparação e, geralmente, em casos muito extremos. Nas reuniões de campanha e, principalmente, nos encontros de avaliação realizados depois das eleições, o comprometimento diferencial dos agentes foi considerado um dos elementos responsáveis por não atingirem a quantidade de votos esperada. Mas essa comparação da dedicação dos sujeitos era feita apenas entre aqueles que participavam e entre aqueles com pouquíssima participação e sem que fossem citados nominalmente, pois isso deveria ser evidente para todos, tanto para os participantes, como para aqueles cujo empenho era objeto de críticas. $\mathrm{O}$ que chama a atenção para outro aspecto do comprometimento que era a necessidade de autoconsciência dos agentes envolvidos. Assim, cada sujeito sabe de si (dos seus compromissos 
pessoais, das suas responsabilidades assumidas com o coletivo, da sua vontade de participar) e, portanto, deveria refletir e atuar com base no que achasse justo e honesto para com o coletivo e para consigo mesmo. Na prática houve momentos em que o coordenador de campanha precisou intervir, reforçando o senso de que o tempo estava passando e de que as lacunas na agenda de campanha precisavam ser preenchidas. Algumas semanas em que ocorreram poucas atividades eram justamente aquelas mais distanciadas das reuniões de campanha, como se houvesse certo arrefecimento das iniciativas dos cidadanistas na ausência de algum estímulo (externo). Esse estímulo não provinha exclusivamente da coordenação de campanha e a rede social WhatsApp também teve um papel fundamental nesse sentido.

\subsubsection{Fazendo campanha com Whats $A p p$}

Em meados de maio foi criado, no aplicativo WhatsApp, o grupo Mandato Cidadanista EM, para reunir os cidadanistas do bairro de Ermelino Matarazzo. Fui adicionado no grupo no mês de agosto, quando as atividades de campanha no bairro passaram a se tornar mais frequentes. No final de agosto foi criado o grupo ZL:Mandato Cidadanista, para reunir os cidadanistas da Zona Leste, sobretudo, de Ermelino e Itaquera, grupo no qual ingressei no começo de setembro. E, por fim, no começo de outubro, também fui adicionado ao grupo VoluntarixCidadanista5088, criado no final de agosto e que possui a seguinte descrição: Grupo de articulação dxs voluntarixs para as ações de campanha do Mandato Cidadanista com Célio Turino 5088. Fica claro que o terceiro grupo poderia contribuir muito para o andamento da pesquisa já que nele foram combinadas muitas atividades de campanha. No entanto, só fui adicionado no grupo na semana das eleições, razão pela qual estive ausente de uma ou outra mobilização (além de ter perdido discussões potencialmente relevantes), mesmo que alguns interlocutores me avisassem frequentemente sobre a ocorrência de alguma ação. De fato, fui tomando conhecimento da existência dos grupos com o andamento do processo eleitoral e, em algumas ocasiões, vi que mesmo alguns cidadanistas entravam nos grupos muito tempo depois de terem sido criados. Era muito desafiador saber exatamente quantos grupos estavam ativos e quantos foram paulatinamente sendo abandonados (e aqui eu também incluo o período pré e pós-eleitoral e outras plataformas como o Telegram) e a ideia de querer fazer parte de todos os grupos existentes não me pareceu, nem necessária, nem adequada. Penso que uma boa dose de bom senso é fundamental e o pedido para ingresso nas redes sociais dos cidadanistas deveria 
ocorrer de forma natural, em momento propício, cuja identificação comportaria, sem dúvida, outra boa dose de intuição e análise subjetiva. No caso do grupo dos voluntários, eu só fiquei sabendo da sua existência tardiamente, uns dez dias antes de ser incluído, e mesmo assim me parecia um canal de diálogo que demandava alguma reserva e que não era conveniente eu fazer parte. Por mais que eu tivesse sido muito bem acolhido no coletivo e tivesse muitas afinidades políticas com os meus interlocutores, vez ou outra, havia pequenos sinais de incômodo ou preocupação com a minha presença, sobretudo no começo da pesquisa. Isso se deveu, em parte, ao diferencial da pesquisa antropológica em relação a outras ciências sociais, como a Sociologia ou a Ciência Política. Lembro de alguns interlocutores que se mostravam surpresos com o fato de eu ter interesse (observando e anotando) em aspectos que lhes pareciam incabíveis para um estudo da política (como o desenho dos impressos ou as dinâmicas de caráter lúdico), por mais que eu tivesse explicado essas características do trabalho de campo. ${ }^{32} \mathrm{Na}$ verdade, tomando como base os comentários de alguns cidadanistas, suponho que a maioria esperava que eu recolhesse algum material, tomasse notas de algumas reuniões, fizesse algumas entrevistas e encerrasse a pesquisa de campo. Seja como for, não deve ter sido muito agradável a sensação de ser observado e analisado, por mais que meus objetivos fossem aceitos e até admirados. Nos grupos de WhatsApp havia ainda um complicador adicional, que é o fato de pessoas ingressarem e começarem a interagir no grupo sem saberem que estavam sendo observadas, o que, nessa modalidade de trabalho de campo, acaba sendo, muitas vezes, inevitável. Além disso, nos grupos digitais as fronteiras comumente estabelecidas entre o discurso público e o privado tornam-se bastante instáveis. Eventualmente acontecia de, no meio de conversas sobre estratégias eleitorais e compartilhamento de memes e notícias, aparecerem mensagens que exprimiam inquietações e desabafos que talvez não fossem compartilhadas em reuniões públicas presenciais, situação que requer, mais uma vez, cautela e responsabilidade ética por parte do investigador.

O WhatsApp funcionou como importante ente articulador e conector dos integrantes do Mandato Cidadanista e a sua arquitetura teve efeitos nada desprezíveis sobre as formas de atuação política do coletivo. O seu modo de operação como empilhador de mensagens remete ao efeito fragmentador e dispersor mostrado no capítulo anterior em relação ao Fórum de mensagens. Se considerarmos que o principal objetivo dos grupos de WhatsApp era a articulação dos cidadanistas para ações de campanha, é preciso reconhecer que o funcionamento do aplicativo também promovia

32Talvez, pelas características do meu campo, teria sido muito mais efetivo criar um blog, uma página no Facebook ou mesmo um texto explicativo em um editor de texto compartilhável, esclarecendo esses aspectos fundamentais da pesquisa e ter divulgado continuamente o link para acessá-lo nas redes sociais utilizadas pelos meus interlocutores. 
lógicas diversas daquelas nas quais se baseavam as ações pretendidas pelo coletivo. Na medida em que a campanha era baseada no agendamento contínuo e sistemático de atividades, o empilhamento diacrônico de mensagens dificultou muito o acompanhamento de todos os agendamentos realizados e o controle de compromissos ${ }^{33}$. Soma-se a isso o fato de que a maioria dos cidadanistas estava inscrita em mais de um grupo relacionado ao Mandato. Certa noite, caminhando em direção à estação de metrô, comentei com um interlocutor a respeito de uma atividade que tinha sido promovida no centro da cidade, o qual manifestou imediatamente seu desagravo por não ter sido avisado, embora essa atividade tenha sido postada com antecedência no grupo em que ele estava inscrito e acessava. Em outra circunstância ouvi um relato de um cidadanista sobre ter errado o horário e data de uma roda de conversa por ter confundido com outro evento que foi publicado no mesmo grupo posteriormente. Também não posso deixar de lembrar que, em um dia muito atribulado, perdi uma roda de conversa em Ermelino Matarazzo por ter consultado outro grupo em que havia uma atividade semelhante, mas em um horário diferente. Se equívocos do tipo ocorrem em grupos com dezesseis ou vinte inscritos é de se esperar que um grupo com cinquenta ou noventa membros as complicações aumentem consideravelmente. Essa dificuldade em acompanhar a agenda coletiva também contribui para diminuir a sensação de transparência, uma noção que, conforme vimos no capítulo anterior, é componente fundamental da noção de democracia do coletivo. Ao reclamar por não ter sido convidado para a atividade no centro da cidade, o primeiro interlocutor declarou que situações como essa o faziam se sentir deixado de lado, como se não fizesse efetivamente parte do coletivo ou como se não fosse tão importante para o Mandato quanto os demais.

O compartilhamento de fotos nos grupos digitais das ações de campanha também parece ter funcionado como um estímulo para outras iniciativas, sobretudo em semanas com poucas atividades nos bairros. É como se a imagem de uma ação puxasse outras ações, seja por ser uma inspiração para outras atividades, seja por lembrar a todos que alguns estão na luta e que é preciso seguir o seu exemplo para alcançar a vitória. Dificilmente uma foto postada em um dos grupos deixava de ser respondida com: expressões, sinais e imagens de incentivo ou admiração; mensagens encorajando todos a atuarem; outras fotos de ações (imediatamente após a primeira foto ou mesmo no dia seguinte). Mais do que apenas o mero registro de um momento, essas imagens colocavam em movimento o coletivo, pois elas faziam sentir, faziam pensar e faziam agir.

33 Essa observação que, a princípio, pode parecer destituída de grande importância, não me parece nada trivial quando nos damos conta de que inúmeros coletivos no mundo têm adotado esse aplicativo para as suas atividades políticas, incluindo partidos como o Podemos espanhol. 
Ao deslizar o polegar para baixo sobre a tela do meu Smartphone no grupo digital Mandato Cidadanista - EM ou ZL: Mandato Cidadanista vi que a maior parte das postagens consistia em reflexões e análises políticas (em texto ou em links para textos ou vídeos); convites para eventos sobre temas de interesse comum; vídeos, memes e piadas (a maior parte com humor de caráter crítico-político); ocasionalmente algumas frases de autores conhecidos ou de autoajuda; e muitas notícias, sobretudo, no campo da política institucional. O compartilhamento de notícias - que se intensificou no segundo turno das eleições e continuou sendo realizado cotidianamente no grupo Raiz Nacional - não poderia ser reduzido ao objetivo puro e simples de meio de informação (mostrar e saber o que se passa na política do país), mas deve ser considerado, sobretudo, uma prática de formação, em sentido lato. Em primeiro lugar, ele parece ter contribuído para a criação de uma espécie de mapa dinâmico e coletivo da política, onde o lugar de cada acontecimento e cada personagem era estabelecido, reafirmado ou deslocado. As notícias sobre episódios de agressão a minorias e defensores de causas sociais eram reproduzidas, comentadas e complementadas por outras notícias do gênero, reforçando e dando formas específicas à visão de que estávamos caminhando a passos largos em direção a um regime totalitário. Foi bastante instrutivo ver como ocorreu a transformação da imagem da deputada federal Tabata Amaral, do PDT, de uma companheira na luta pela educação à traidora dos mais pobres. Se, a princípio, ela era defendida por alguns cidadanistas, apesar de discordâncias em relação a algumas de suas ideias (associadas à defesa de aspectos do modelo neoliberal), a 'curadoria' coletiva de notícias acabou convencendo alguns desses ciberagentes de que não era do lado dos mais pobres em que Tabata se colocava. Em segundo lugar, a composição conjunta de um painel dinâmico de notícias parece ter contribuído para criar e reforçar uma experiência compartilhada da (des)ordem política brasileira e para produzir a emergência, o encontro, a circulação e a disseminação de afetos (neste caso, principalmente aqueles associados à revolta e indignação), que reforçavam o senso de 'estar-junto’ e impelia os sujeitos à ação. Isso ficou muito mais claro no segundo turno das eleições em que os sentimentos de raiva, tristeza e inconformidade e seus efeitos se mostravam de forma amplificada e continuada, como veremos adiante. 


\subsubsection{Liderança e democracia na prática}

Apesar do MC ter sido concebido como um projeto de experiência política coletiva $e$ compartilhada, a figura da liderança foi estabelecida logo de saída, já que a candidatura se constituiu em torno de Célio Turino - a quem foi dirigido o convite para participar do pleito e de quem partiu a iniciativa de montar um mandato de caráter coletivo. Célio sempre teve um papel de destaque na Raiz, atuando ativamente tanto na escrita da carta de fundação do coletivo (o que incluiu a sua participação em debates e discussões conceituais) quanto na elaboração do estatuto, que estabeleceu as linhas fundamentais do seu modo de organização e funcionamento. Tudo isso, somados a uma experiência de quarenta anos como gestor público, à também longeva militância política e a um notável carisma pessoal, fizeram com que Turino conquistasse profunda admiração e respeito entre os cidadanistas. Desse modo, mesmo que o nome para a candidatura tivesse sido escolhido de uma forma mais democrática (a partir da discussão e deliberação de todos, como seria o ideal), seguramente o nome do Célio seria escolhido, se não por unanimidade, por algo muito próximo disso. Mais de uma vez ouvi dizerem que ele cumpria um importante papel aglutinador, no sentido de ter a capacidade de unir as pessoas com facilidade em torno de si, o que não deixava de ser uma preocupação tendo em vista a reconhecida necessidade da construção de uma política que não dependesse de grandes personalidades ou, mais estrategicamente (e de forma algo contraditória), de uma política que apostasse na constituição de outras lideranças para candidaturas futuras.

No começo da campanha, eu me deparei, grosso modo, com dois caminhos: o primeiro era priorizar as atividades de campanha em que o Célio estaria presente e o segundo era acompanhar as ações d@s codeputad@s e voluntári@s nos bairros. No final das contas, a pesquisa se concentrou um pouco mais nos bairros da zona leste e no centro da cidade sem, portanto, perder a maior parte das ações do Célio. Não acompanhei suas atividades de campanha em cidades fora da capital (que não foram muitas) e nem tampouco em outras regiões da cidade, exceto poucas ações (em passeatas e manifestações) na zona oeste. Essas opções nas estratégias da pesquisa são importantes e, sem dúvida, refletem diretamente nos seus resultados, sobretudo na discussão de questões relativas à centralização, liderança e autonomia. No entanto, acredito que obtive muitos ganhos analíticos ao começar com o foco nas ações nos bairros, expandi-lo para as ações mais centrais e depois retornar aos bairros, um movimento que me fez atentar para a emergência de ações organizadas sem o direcionamento de lideranças ou coordenação centralizada. É verdade que algumas vezes o Ivan 
exercia esse papel diretor, mas na maioria das ocasiões suas intervenções tinham um caráter propositivo e incentivador e não foram sistemáticas e diárias.

O caráter personalista da disputa eleitoral seguramente forçou os cidadanistas a uma centralização da campanha na imagem do Célio, afinal de contas os eleitores não iriam votar na Rafaela ou no Thomaz, mas era a imagem do Célio que iria aparecerna urna. Às vezes, @s codeputad@s se mostravam um pouco desconfortáveis com essa situação, principalmente, por ela lhes impor limites para fazer campanha de forma mais autônoma e conquistar um eleitorado que não conhecia o homem de chapéu da foto. Nas caminhadas que acompanhei em Ermelino Matarazzo, o Célio sempre assumia uma posição de destaque, como em uma ação realizada na comunidade Santa Inês.

A caminhada na comunidade foi iniciada por volta das $18 \mathrm{~h} 30$ e contava com a presença de quatorze participantes, além do líder comunitário Shepa, que fez o convite. Apesar da ação contar com poucos participantes, chamou bastante a atenção dos moradores, que observavam com curiosidade a equipe. No trajeto, a maioria dos participantes abordava os moradores, distribuindo panfletos e o jornal Folha Cidadanista (que tinha a matéria e a foto do Célio com o papa Francisco na primeira página). O Célio tomou a dianteira e adentrou os comércios que estavam abertos, na maioria das vezes entrava sozinho e os outros componentes da caminhada permaneciam na rua, alguns distribuindo impressos para os passantes e para os moradores que estavam nos portões e quintais de suas casas, como era o meu caso. Algumas vezes ele falava sobre a sua proposta de bolsa para os jovens, em outras ele falava do caráter comunitário e compartilhado do Mandato. O Célio foi quem mais distribuiu material e conversou com as pessoas. Por volta das $20 \mathrm{~h} 00$ a caminhada termina na paróquia de São Francisco de Assis. O Célio, a Silvana e mais duas pessoas ficam na igreja para a missa e eu me despeço deles e dos demais e volto para casa.

Ao tomar a iniciativa da distribuição de material, o Célio era imediatamente seguido pelos que, até então, não se ocupavam de nenhuma atividade, comportamento que também pude presenciar em outras ocasiões. É como se, com sua ação, ele chamasse a atenção de todos para a necessidade de sair da inércia e colocar as mãos na massa e, ao mesmo tempo, reforçasse a ideia, muitas vezes reiterada, de que o líder, além de não possuir nenhum privilégio sobre os demais, deve servir ao coletivo e não ser servido por ele. Não é demais chamar a atenção para o fato de que, segundo o líder comunitário Shepa, vários candidatos se aproximaram dele para fazer campanha na Santa Inês, mas nenhum se dispôs a adentrar as ruas da comunidade para conversar com as pessoas, a não ser na sua rua de acesso principal. Isso chama a atenção também para a ideia de comunidade 
que permeia as ações do coletivo que, embora já estivesse presente nos discursos da Raiz, adquiriu centralidade e foi realizada na prática na campanha do Mandato Cidadanista.

\subsubsection{Política na comunidade}

Comunidade era um termo onipresente nos discursos de campanha dos cidadanistas, tanto nas conversas com o eleitorado quanto nos diálogos entre os seus correligionários de Mandato. Embora a noção já fosse acionada na Raiz - e ela teve presença marcante na Carta Cidadanista -, ela só ocupou o lugar proeminente que assumiu com a constituição do mandato coletivo. Isso se explica, em parte, pelo fato da Raiz ter, por um longo período de tempo, concentrado as suas ações no digital, lugar onde a noção raramente se apresentava de forma direta. As críticas ao digital levaram ao fortalecimento dos discursos em favor de uma retomada das relações presenciais, de modo geral, e do comunitário. O imaginário do comunitário colocou-o em relação de oposição ao digital e sempre esteve profundamente associado a uma série de predicados que remetem à oposição clássica do pensamento social comunidade/sociedade e, em última instância, ao dualismo natureza/ cultura, embora essas oposições não configurassem um binarismo estático e estivessem carregadas de nuances e tensões. Como vimos no capítulo anterior, a própria ideia do digital como o lugar das relações frias e distanciadas era desafiada por práticas que promoviam relações de camaradagem e afeto. Ainda assim, a comunidade era comumente associada à proximidade, à cooperação (e ao compartilhamento), à simplicidade, às relações de afeto, ao cuidado, à conversa e, por último, mas não menos importante, ao território. Assim, quando os cidadanistas falavam em obter uma candidatura orgânica e natural para o próximo pleito municipal, eles estavam falando não apenas de um candidato dedicado a alguma causa social (um ativista), mas, sobretudo, de um candidato que possuísse vínculos com alguma comunidade e que, idealmente, estivesse envolvido com ações de intervenção nessas localidades. As relações comunitárias de certa forma eram vistas como uma proteção ou um antídoto contra a desagregação social e o desmoronamento da legitimidade da representação política. Os cidadanistas supunham - durante e, especialmente, depois da campanha que uma ação continuada ao lado das comunidades seria um poderoso meio de angariar o apoio e votos em uma campanha eleitoral, mas para isso seria necessário saber ouvir e falar a língua do povo. Vem ganhando força nos últimos anos, principalmente depois do resultado das eleições (com o encolhimento dos partidos tradicionais de esquerda), a ideia de que o discurso da esquerda se 
distanciou do eleitorado e de que é preciso se reconectar com a voz do cidadão comum, diagnóstico compartilhado pelos meus interlocutores. Mas, na prática, as coisas se passavam de um modo um pouco mais complicado e os cidadanistas logo viram que o discurso que efetivamente mobilizava as pessoas ia justamente no sentido contrário dos princípios defendidos pelo coletivo. Foi algo que pude facilmente constatar em algumas situações de interação e diálogo com as comunidades, como em uma roda de conversa promovida na parte externa de uma paróquia, na Vila Robertina, região leste de São Paulo. Em certo momento da conversa sobre as propostas do Mandato, três dos presentes começaram a defender pautas que estavam em total desacordo com os ideais do Mandato, como a defesa da palmada como forma de educar os filhos (defendida, curiosamente, por uma professora) e a separação dos jovens rebeldes dos demais alunos nas escolas, o que deixou o Célio visivelmente constrangido e o fez logo mudar de assunto. Os meus interlocutores tinham consciência de que a situação política favorecia discursos que promoviam valores opostos aos seus (como a violência, o preconceito etc.), como bem resumiu a fala de Eduardo, dita logo após a eleição: perdemos a eleição porque falamos de amor. Entretanto, ao mesmo tempo, persistia a ideia de que a comunidade guardaria uma espécie de essência que remete aos bons valores humanos. Algumas vezes essa visão era expressa, inclusive, em termos históricos, como se o retorno à comunidade fosse o retorno a nossa raiz - e voltar a essa raiz seria fortalecer o que haveria de melhor em nossa humanidade. Esse discurso de retorno à raiz era tanto acionado para se referir às nossas raízes culturais (as três raízes ameríndia, africana e europeia) como para se referir a formas de socialidade que remontariam a um tempo passado genérico, quando elas eram predominantes. Também era associado a uma reconexão com a natureza e com formas de socialidade que lhes seriam mais próximas e que foram sendo perdidas no decurso do desenvolvimento da civilização e do capitalismo.

\subsection{Da urgência das ruas ao sentimento das urnas}

Com o avanço da disputa eleitoral um senso de urgência começou a tomar conta dos cidadanistas, preocupação que, como vimos, entrava em conflito com a forma de pensar a política do coletivo que enaltecia a conversa imersiva e o trabalho de formação política, modelos de atuação claramente opostos ao apelo direto por votos e à conversão instantânea, típicos do jogo eleitoral. Era a chegada a hora de atingir o maior número possível de eleitores e havia cada vez menos tempo 
para rodas de conversa e pequenas reuniões com as comunidades. $\mathrm{Na}$ semana que antecedeu a eleição intensificaram-se as atividades de distribuição de material impresso nos locais de grande fluxo de pessoas como as saídas de estações de metrô e terminais de ônibus. Em muitas ações os cidadanistas dividiam-se entre lugares diferentes, algumas vezes aproveitando a proximidade com seus locais de estudo e residência, em outras, eles combinavam ações conjuntas em equipes maiores, como foi o caso em locais de grande circulação.

Com a reta final da campanha se aproximando, minha atenção para com o alerta de mensagens do WhatsApp - que sempre fôra muito reduzida antes do começo da pesquisa - passou a ser redobrada, para que eu pudesse planejar a minha agenda adequadamente. A iniciativa para realizar uma atividade podia partir de qualquer um, a qualquer hora, bastava mandar uma mensagem e propor uma ação ou perguntar: amanha ves estão pensando em vir na feira aqui em Ermelino? Por simples que possam parecer, as ações de panfletagem também contribuíram para desvelar os modos de fazer, sentir e conceber a política dos cidadanistas. Para um olhar mais apressado, poderia parecer a atividade técnica por excelência desprovida de qualquer sentido que não seja o de colocar um pedaço de papel nas mãos da maior quantidade possível de pessoas. Entretanto, nada seria mais enganador, pois como vimos anteriormente, os cidadanistas improvisaram uma forma de abordagem que conciliava a necessidade de atingir um amplo eleitorado com a forma de fazer política, digamos assim, mais dialógica do coletivo, que alguns chamaram de panfletagem qualificada. Mesmo assim esse tipo de abordagem não consistia numa fórmula a ser aplicada a todas as ocasiões, pelo contrário, havia grande abertura ao improviso e à criatividade. Tomo como exemplo a distribuição de impressos realizada na mobilização contra candidatura de Bolsonaro (mobilização que ficou marcada pelo uso e disseminação da hashtag \#elenao), no Largo da Batata, na zona oeste da cidade. Tratava-se de uma situação bastante favorável para abordagem na medida em que o público era majoritariamente de esquerda e, o mais importante, tinha disponibilidade de tempo para conversar.

Cheguei um pouco antes das 17 horas no Largo da Batata. A praça estava lotada, mal havia espaço para caminhar. Fiquei andando lentamente por entre as pessoas para ver se encontrava algum cidadanista ou a banca do Mandato, até que finalmente avistei a bandeira da Raiz tremulando no alto. Ao me aproximar da banca, vi o Gabriel distribuindo material impresso a favor da liberação da maconha. Cumprimentei o Gabriel, o André, o Renato, a Kida e a Fernanda, que agitava a bandeira. O André, que vestia a camiseta branca da Raiz, estava distribuindo panfletos do lado direito da banca e colando adesivos nas camisetas das pessoas que passavam onde estava escrito tudo para todas, seguido pelo número e nome do Célio 
Turino. Depois direcionei minha atenção para a intervenção do Gabriel, que distribuía os impressos de cor rosa em favor da canabbis. Ele oferecia e entregava os panfletos para os passantes enquanto falava em voz alta: MACONHA! Legalização da MaCÔnha, você é a favor? - perguntava, dirigindo-se visualmente às pessoas e entregando para cada uma um impresso. E continuava repetindo: alguém mais é a favor da legalização da maCÔÔnha? - falava colocando ênfase e prolongando a segunda sílaba (co), o que conferia um efeito jocoso a sua fala. A repetição da pergunta, você é a favor?, funcionava como um convite ao estabelecimento de uma relação comunicativa com os sujeitos abordados que, na maioria das vezes, respondiam favoravelmente. As pessoas que fixavam o olhar no Gabriel dificilmente ficavam indiferentes e era muito comum pegarem o panfleto e sorrirem, balançando a cabeça afirmativamente.

Algumas diziam frases como: Ai sim ein!

Fatores como o perfil do público e modo de circulação foram fundamentais para improvisação dessa estratégia de abordagem, já que não poderíamos esperar a mesma estratégia nas ações de distribuição de impressos realizadas nas saídas das missas e muito menos com o panfleto em prol da legalização da cannabis. As ações de panfletagem, realizadas nos terminais de ônibus também não abriram mão da criatividade, embora ela não fosse tão evidente como no caso do Gabriel. Apesar de sutil, a uma primeira olhada, a experimentação e a variação de estratégias nessas situações eram muito recorrentes. Primeiro parecia-lhes ser uma boa estratégia ficar nos espaços com maior fluxo de pessoas, onde centenas passavam em poucos minutos. Ao perceber que a maioria andava muito rápido e não demonstrava qualquer interesse em pegar o material, os cidadanistas se deslocaram para outras plataformas onde os transeuntes caminhavam mais devagar e se mostravam mais disponíveis para receber o material e mesmo conversar. Minutos depois perceberam que as pessoas nas filas dos pontos de ônibus ficavam paradas por um tempo razoável e que era uma situação favorável para a distribuição do jornal e uma conversa mais envolvente. Depois atravessaram as plataformas procurando locais que pareciam favoráveis para a abordagem mais detida. O ponto é que os cidadanistas não pareciam satisfeitos em ficar apenas parados entregando impressos para milhares de pessoas. Enquanto os distribuidores de impressos de outros candidatos permaneciam praticamente no mesmo lugar por horas (entregando panfletos freneticamente onde quer que houvesse grande circulação de pessoas), os cidadanistas tinham mudado de tática e lugar um sem-número de vezes. Tudo se passava como se os meus interlocutores tivessem sido tomados por certa inquietação e pelo senso de que era preciso inventar novas estratégias, fazer pequenas variações, por mais sutis que pudessem parecer. Tanto na intervenção realizada na passeata antibolsonaro, como nas ações nos terminais, havia o forte sentimento de que 
era preciso imprimir uma marca diferencial que indicasse que ali não se tratava de uma distribuição de panfletos qualquer, como seria a de outros candidatos, mas sim de uma ação que apresentava outro modo de fazer política.

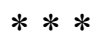

A chegada da eleição foi um momento bastante tenso para todos já que, além da expectativa a respeito da eleição do Mandato, havia também a preocupação com a provável ida para o segundo turno do candidato do PSL. A percepção geral do coletivo foi que a campanha representou a irrupção do ódio e de várias formas de preconceito que sempre estiveram em um estado latente na sociedade, mas que nunca encontraram expressão política adequada, até a candidatura de Bolsonaro. No dia 07 de outubro, dia da eleição, todos foram convidados via WhatsApp para se encontrarem no salão social do Cifa, órgão vinculado à Igreja Nossa Senhora do Carmo, em Itaquera, para acompanharem a apuração e fazerem uma pequena confraternização. Cheguei por volta das $19 \mathrm{~h} 00$ no local e cumprimentei a todos parabenizando-os pela dedicação, já sabendo que o Célio não iria conseguir o número de votos suficientes para ser eleito. Naquele momento havia na sala pouco mais de trinta pessoas, a maior parte sentada em cadeiras dispostas semicircularmente. Havia uma mesa com alguns lanches levados pelos presentes, como amendoins, esfihas, refrigerantes e sucos, e um telão onde acompanhávamos os boletins televisivos sobre a apuração. O clima era de muita tristeza, pois além do desempenho do Célio ter sido muito aquém do esperado, a esquerda, como um todo, teve um péssimo desempenho, a despeito de algumas importantes vitórias pontuais. O Célio fez uma breve declaração, agradecendo o empenho de todos e lamentando o desempenho da esquerda na eleição, dizendo que a disponibilidade de recursos determinou diretamente o resultado da votação. Avisou também que não seria mais o candidato titular em 2020. O Ivan tomou a palavra e disse que viu a atuação do Mandato Cidadanista como uma semente, uma esperança para 2020. Thomaz falou que, apesar da tristeza com o resultado, era preciso celebrar, pois as pessoas se transformaram durante a campanha. Completou dizendo que não havia uma configuração astrológica favorável naquele momento e que Deus, o grande espírito, sabe o que faz. As falas se alternaram entre a consternação com o resultado, a preocupação quanto ao futuro político do país, a celebração das relações que se constituíram e se fortaleceram entre os membros da equipe e a necessidade de manter unido o coletivo para a construção de um projeto de candidatura para as eleições municipais de 2020. Após os discursos, a sala foi tomada por um 
silêncio raramente visto nas reuniões do coletivo, às vezes quebrado por uns breves borburinhos, logo descontinuados. Nesse momento eu me encontrava sentado em uma das cadeiras dispostas ao redor da mesa, mas um pouco afastado, atento às ações dos presentes e conversando com aqueles que se dirigiam a mim. Os presentes foram se servindo e aos poucos o silêncio foi sendo quebrado com comentários esparsos e diálogos curtos e, uma vez por outra, as atenções se viravam para o telão com a projeção dos primeiros resultados das eleições em todo o país e com as entrevistas televisivas com os candidatos vitoriosos e derrotados. Pouco a pouco os presentes foram se retirando do local até que o esvaziamento do encontro precipitou o seu fim, então organizamos o espaço (retirando os alimentos da mesa e colocando as cadeiras nos seus lugares) e nos retiramos de forma discreta, sem tocarmos no assunto da eleição, mas com expressões claras de pesar e descontentamento. Apesar dos discursos terem chamado a atenção para a necessidade dos cidadanistas se manterem unidos, no encontro não se falou a respeito do futuro do movimento, nenhum plano e nenhuma ação futura foram propostos, a reunião terminou com um forte senso de término de um ciclo e de incertezas quanto ao porvir.

No dia seguinte após a eleição, ainda digerindo o resultado das urnas, também fui tomado por um profundo sentimento de incerteza, primeiro, por não saber se a pesquisa de campo continuaria e, depois, pela dúvida quanto à possibilidade de, em tão pouco tempo, revertermos o quadro eleitoral para impedir a vitória definitiva de Bolsonaro, no segundo turno. Naquele momento, pesquisa e vida se mostraram, mais do que nunca, indiscerníveis e as incertezas me levaram à paralisia nos primeiros dias daquela semana, como se esperasse por algum acontecimento que me despertasse para a ação. Aos poucos as postagens nos grupos de WhatsApp começaram a quebrar o silêncio com mensagens sobre os números da eleição (mostrando, por exemplo, que havia um percentual de eleitores que não tinha votado no Bolsonaro e que permitiria alcançar a vitória); estratégias para conquistar votos em favor do candidato do PT, Fernando Haddad (com dicas para abordagem e retóricas para o convencimento do eleitorado); e a divulgação de reuniões para a construção de frentes de luta e planejamento de ações de campanha mais eficazes. O teor das postagens foi aos poucos conformando um ambiente com claro sentido de resistência, um chamado reiterado em defesa da democracia e dos direitos sociais. A divulgação das projeções mostrando a possibilidade matemática de virada indicava ao mesmo tempo uma pequena janela para intervenção no real e um alerta para a magnitude da tarefa e necessidade de reação imediata para lograrem o sucesso. Além disso, o compartilhamento de notícias sobre atos de intolerância e violência perpetrados por eleitores de Bolsonaro e dos discursos de ódio proferidos pelo próprio candidato, 
mobilizavam e davam forma aos afetos de tal modo que era quase impossível ficar indiferente. Como alguns cidadanistas comentaram em mensagens e em reuniões de mobilização durante a campanha do segundo turno, não dá pra ver tudo isso que tá acontecendo e ficar parado, como se o compartilhamento reiterado dos acontecimentos impelisse os sujeitos à ação e, nesse caso, ficar parado seria mais do que simplesmente a ausência de ação, pois implicaria em luta contra afetos que atravessavam os sujeitos e os compeliam ao movimento. Assim, seria praticamente inevitável que fossem afetados por essas notícias e cada nova postagem compartilhada contribuía para aumentar o sentimento de incrustação e a intensidade das experiências políticas dos sujeitos, assim como os ajudava a conformarem um imaginário do momento político eleitoral. Mas o funcionamento dos grupos digitais de WhatsApp não pode ser entendido sem levarmos em consideração o ecossistema de notícias mais amplo que envolvia múltiplos agentes e veículos, como blogs, páginas de ativistas e movimentos sociais, outras redes sociais (principalmente o Facebook), os grandes meios de comunicação, entre outros. Todas essas agências contribuíram para mover os sujeitos e para produzir identificações políticas coletivas e sentimentos de revolta e indignação que os incitavam a agir. No WhatsApp, as imagens, memes, depoimentos pessoais e notícias (ou seus títulos) reiteravam, marcavam e inseriam os acontecimentos num novo arranjo significativo que imprimia uma forma característica ao coletivo digital e ajudava a engendrar as imagens e as experiências da desordem e da catástrofe política iminente. Assim, o assassinato de um professor de capoeira motivado por críticas a Bolsonaro, na Bahia, a invasão da reunião da Conferência Nacional dos Bispos do Brasil com agressores proferindo ofensas de teor anticomunista e discursos de ódio de pessoas próximas - como a declaração de um familiar de um membro homossexual do MC (a respeito de notícias sobre ataques homofóbicos) que dizia que viado tem que morrer mesmo - eram enredados em um todo significativo que adquiria ainda mais consistência na medida em que estavam imbricados nas experiências íntimas dos sujeitos.

Durante a campanha, vários cidadanistas relataram terem que lidar com reações hostis do eleitorado, especialmente em alguns casos em que eleitores do Bolsonaro perceberam que os cidadanistas assumiam um posicionamento político radicalmente oposto ao do político de direita. Esse clima de hostilidade foi, inclusive, a razão pela qual a proposta de ação de campanha Testemunha de Jeová (bater à porta dos eleitores) foi prontamente descartada. Eu mesmo vivenciei a tensão política daquele momento quando, no começo da semana seguinte, saí para colar alguns cartazes no bairro com frases polêmicas ditas por Bolsonaro até que um passante percebeu o cartaz recém-fixado e o rasgou imediatamente dirigindo-se a mim em tom ameaçador, dizendo que eu não 
devia espalhar aquelas mentiras. O ocorrido naquela manhã não apenas reforçou em mim o sentimento de que estávamos vivenciando uma escalada de ódio e intolerância, impulsionada pela candidatura da direita, mas foi decisivo para tornar onipresente a sensação de que os atos de intolerância política passaram a fazer parte das situações cotidianas mais triviais, em convergência com a percepção crescente dos meus interlocutores. Posso afirmar que, foi no âmbito dessas experiências emocionais que se deu a máxima identificação do eu-investigador com os sujeitos investigados, contrariando os preceitos da ontologia naturalista, calcada na separação sujeito-objeto. Ao aumentar a intensidade da experiência, os afetos parecem contribuir para elevar a compreensão a uma forma de verdade que implica o sujeito conhecedor de modo visceral, já que se trata de um conhecimento que ressoa marcadamente nos corpos, o que sempre foi explicitamente reconhecido pelos agentes. A pressão no peito, a falta de ar, o coração acelerado, os tremores incontíveis nas mãos, dores e sensações na cabeça (de pressão ou latejamento), o calor no peito e nas zonas lateral e frontal da cabeça, eram sensações sempre atreladas a sentimentos referidos como estresse, angústia, depressão (em um sentido genérico de tristeza profunda e continuada), desalento, medo, raiva, entre outros. Em quase todas as ocasiões em que houve a associação direta entre corpos e afetos, ela ocorria no campo dos afetos negativos, o que é esperado, por se tratar de um momento em que a intolerância e o ódio se tornaram característicos do processo político. Nesse sentido negativo, as emoções também eram entendidas como uma espécie de fluxo energético com enorme potencial disruptivo que, se contido no interior dos sujeitos, colocaria em risco a sua integridade física e mental. Seria então preciso que essa tensão acumulada fosse canalizada para seguir um curso mais favorável, que ela fosse colocada para fora por meio de alguma ação catártica ou compartilhada com outros membros do coletivo, aliviando a carga sobre o sujeito, ou mesmo convertida em impulso inicial para ações construtivas podendo, nesses casos, produzir afetos positivos. Assim podemos entender como as emoções originadas de situações cotidianas de ódio e intolerância, vivenciadas direta ou indiretamente, fizeram com que os cidadanistas chamassem reiteradamente a atenção para a importância do acolhimento e da conversa afetiva e alertassem para os perigos do isolamento. $\mathrm{O}$ compartilhamento e o reconhecimento de experiências afetivas comuns concorreram para reforçar o sentimento de pertencimento, intensificado pelo fato de pessoas muito próximas aos cidadanistas terem apoiado a candidatura Bolsonaro, incluindo vizinhos, amigos e familiares.

Essa eleição revestiu-se, para esses sujeitos, de um caráter marcadamente distinto de todas as outras: pois não se tratava apenas de uma escolha entre um candidato de esquerda e um de direita, mas da defesa de direitos e valores básicos que nunca, desde a ditadura, estiveram sob 
ameaça tão flagrante, como costumava pontuar Célio. Causava-lhes profunda tristeza, raiva e indignação ouvirem repetidamente de parentes e amigos próximos que o candidato tinha razão, que polícia tinha que matar mesmo, que casais gays demonstrando afeto em espaço público deveriam ser espancados, entre outros absurdos proferidos pelo candidato. Os ataques verbais de Bolsonaro às minorias, às instituições democráticas e direitos fundamentais eram entendidos como ameaça à própria existência desses agentes e o mais doloroso era constatarem que pessoas a quem amavam e admiravam estavam, de algum modo, contribuindo para a escalada de intolerância que os colocava em risco - aliás, em sua perspectiva, os próprios partidários de Bolsonaro estariam atuando contra si próprios embora não tivessem consciência disso. Assim, a eleição foi marcada pelo acirramento de divisões e pela deterioração, quando não rompimento, de inúmeros vínculos sociais no campo de relações pessoais mais amplo (para além do MC), por um lado, e um estreitamento dos laços sociais entre os integrantes do coletivo, por outro. Além disso, esses sentimentos contribuíram para abrir o coletivo a outras alianças e experiências e produzir novas relações e também para que a ideia de compor frentes de luta ganhasse centralidade na agenda política do coletivo. Se a raiva, a tristeza e o medo reuniram os sujeitos imprimindo forma característica ao senso de urgência (de que é preciso fazer algo), o ‘estar-junto' e o 'sentir-junto', característico das ações de resistência, pareciam atuar como forças conectivas que iam muito além da mera resistência de caráter negativo. Pois se o lema ele não traduzia de imediato o sentido negativo das ações de resistência, sua incompletude constitutiva parecia, do mesmo modo, soar como um chamado para a afirmação: afirmação das identificações políticas dos sujeitos, da democracia que aspiravam e da sua capacidade de ação criativa e propositiva. A participação em ações de mobilização na campanha antibolsonaro contribuiu para superação do desânimo pós-primeiro turno e para re-pensarem e atualizarem, na prática, suas concepções de política e democracia em resposta a um cenário político que, se já era ruim antes, se mostrava agora como hipérbole de todas as situações cotidianas de misoginia, preconceito e intolerância que sempre testemunharam no país. A ideia de que a sociedade brasileira sempre foi intolerante e preconceituosa e que a candidatura da direita apenas deu-lhe voz e expressão política, começou a fazer parte das reflexões e discursos do coletivo, em linha de convergência com análises que têm sugerido que essas eleições tiraram a máscara de cordialidade dos brasileiros (MOTA 2019) ${ }^{34}$. De todo modo, seria preciso encontrar meios de avançar na luta pela igualdade e pela democracia mesmo com o quadro desafiador de devastação social, política e institucional que se acelerou após o impeachment fraudulento da ex-presidenta Dilma Roussef.

34 Visão que, em grande medida, se contrapunha à ideia - muito comum nas reflexões cidadanistas sobre o Brasil - de que haveria uma bondade (cordialidade, empatia) intrínseca ao brasileiro. 
Nesse momento estava ficando claro para os cidadanistas que era necessário, mais do que nunca, prosseguir na defesa das bandeiras da Raiz, embora a campanha do Mandato e a experiência das mobilizações do segundo turno tivessem mostrado que uma política orgânica - que fincasse raízes sólidas na sociedade, como sempre defenderam - necessitava de uma redefinição de suas estratégias e uma reconfiguração de sua linguagem para que pudessem dialogar com as pessoas comuns, aquelas que estavam distantes da política institucional e dos movimentos sociais.

\subsection{Seguindo em frente}

Se os dias posteriores a eleições são sempre marcados pelas avalanches de notícias sobre os candidatos eleitos, suas biografias, trajetórias políticas, promessas de campanha, expectativas dos mercados etc., nessa eleição tudo isso foi amplificado e conformado pela potência característica das redes sociais. A única forma de escapar da onipresença do tema vitória de Bolsonaro, seria por meio de uma ação deliberada de isolamento, como alguns cidadanistas disseram ter feito em alguns momentos e que eu mesmo tentei fazer, ao menos na maior parte dos primeiros dias, fechado no meu quarto, praticamente sem acesso às redes sociais ou aos meios de comunicação. Com receio de perder algum acontecimento importante, interrompi meu isolamento no terceiro dia para ler as postagens dos cidadanistas no WhatsApp que, em larga medida, convergiam no seu conteúdo com as postagens dos outros grupos digitais dos quais faço parte (mais especificamente, aqueles com pessoas ligadas à esquerda partidária e universitária). Em primeiro lugar, as postagens reproduziam notícias negativas sobre os planos e declarações dos integrantes do governo eleito (como a absorção do ministério do meio ambiente pelo ministério da agricultura e o projeto para o fim do investimento em atividades culturais pelo chamado sistema S) e também sobre a onda de retrocessos que estava na pauta dos últimos meses do legislativo - postagens que não se distinguiam muito das notícias compartilhadas nos meus outros 'grupos-web'. Pouco frequentes, mas muito marcantes por sua densidade emocional, eram as mensagens de desabafo que expressavam o desgaste subjetivo provocado pela leitura continuada dessas notícias, a ponto de, nos primeiros encontros após a eleição, alguns interlocutores se referirem a sua ausência nas redes sociais como uma desintoxicação; a postagem compartilhada pelo Valdir no grupo ZL: Mandato Cidadanista 
exprimiu com notável expressividade o modo como era acionada essa noção e a dinâmica dos afetos característica do final da campanha eleitoral que tem sido discutida aqui:

Para os próximos dias eu sugiro: desintoxicação das redes sociais, silêncio, música, abraço, poesia, literatura, pequenas rodas de afeto com os pares e espaço para respiração lenta e profunda. Se afastem de pessoas nocivas, dos parasitas que vão sentir prazer com a tristeza e decepção de vocês. Não as alimente. NUNCA! Apenas se afastem ou ignorem. Mas também não se deixem dominar pelo medo. Se protejam, apenas. Não se isolem, não se dispersem. Criem redes de cuidado uns com os outros. Alguns dos nossos perderam amigos e família pelo caminho, acolha-os em suas casas, suas famílias e suas vidas. E se foi você quem os perdeu peça acolhimento aos outros. Nós somos muitos. Família não é sangue, é afeto. Vamos viver nosso luto, vamos chorar, vamos sentir vergonha e raiva, mas vai passar, sempre passa. Nossa luta foi linda e vai continuar sendo. Arranjem modos de purgar a raiva, mas não odeiem, a candidatura fascista se alimentou de afetos ruins e de negação aos direitos humanos mais fundamentais. Não alimentem isso. Nossa força afetiva, acolhedora, amorosa e respeitosa é a fraqueza dessa gente. Vocês repararam que o candidato perdedor parecia mais feliz do que o vencedor? É isso! Eles não conhecem a alegria da luta. Sorriam e riam deles sempre que puderem!. Dancem! Não se deixem contaminar! Como disse o poeta: "Eles passarão, nós passarinho"

Ademais, nos grupos cidadanistas havia uma ênfase reiterada nas ações de resistência, que iam desde o estímulo à participação em enquetes do Senado sobre pautas antidemocráticas, passando pela divulgação de dicas, táticas, instituições e redes de apoio e defesa de direitos (como o compartilhamento de um manual para professores lidarem com o assédio e censura em sala de aula e o contato da Anistia Internacional), até a indicação de um curso com técnicas de defesa pessoal para mulheres e pessoas LGBT, promovido por um coletivo de Ermelino Matarazzo. De qualquer modo, as queixas em torno do contato contínuo com as postagens pós-eleição que, evidentemente, incluíam outras mídias além do WhatsApp, evocavam geralmente as imagens de medo e impotência (as forças do retrocesso eram avassaladoras e, por isso, ultrapassavam a capacidade de ação dos ativistas), de resistência (era preciso fazer algo para defender os direitos conquistados e, quando possível, para garantir novas conquistas) e de solidariedade (algumas categorias sociais eram mais vulneráveis a essas políticas e era preciso atuar em sua defesa). Entretanto, nenhuma dessas mensagens fazia menção à continuidade do movimento, até o quarto dia, quando o Ivan, a Fernanda e o Eduardo postaram nos grupos do WhatsApp um convite para uma nova reunião do coletivo. Os cidadanistas estavam de volta. 


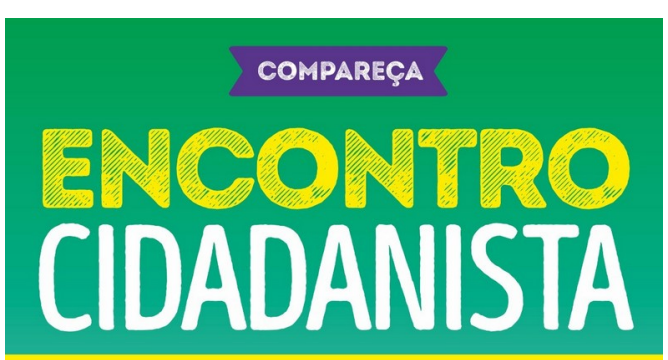

É HORA DE SE JUNTAR, AVALIARE SEGUIR ADIANTE.

REUNIÄO DOS INTEGRANTES DO MANDATO CIDADDANISTA PARA DEFINIÇÃO DOS PROXIMOS PASSOS.

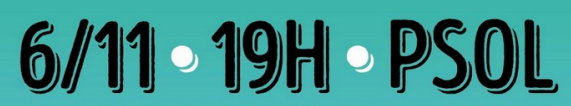

Alameda Barão de Limeira, 1412

Imagem 1. Convite - Encontro Cidadanista, na sede do PSOL. Enviado para os três grupos digitais do MC no aplicativo WhatsApp.

\subsection{1. É na derrota que se vence uma eleição}

As reuniões do Mandato Cidadanista pós-eleição se estenderam até o encontro Nacional da Raiz (Teia Nacional) e consistiram, em termos gerais, na discussão sobre a experiência das eleições, a continuidade do Mandato Cidadanista (que tinha sido constituído, a princípio, apenas para a participação nas eleições) e a relação do MC com a Raiz. Foram, no total, sete encontros, de novembro de 2018 a fevereiro de 2019, sendo que, duas das reuniões sobre mandatos coletivos, não tratavam especificamente do Mandato Cidadanista e tiveram a participação de membros de outros coletivos da região de Ermelino e Itaquera para discutir a ideia de mandato coletivo e a viabilidade de uma candidatura local. Embora esses encontros não tenham sido realizados utilizando o nome do Mandato e mesmo que eles tivessem relação com ações já realizadas periodicamente na Paróquia São Francisco de Assis, podemos, de certo modo, dizer que se tratava de um encontro do MC em Ermelino. Na verdade, se levarmos em conta o ideal de autonomia que permeia as ações do coletivo, não faz muito sentido questionar se essas ações faziam ou não parte do Mandato Cidadanista, afinal de contas, o esperado era justamente que as pessoas tomassem iniciativas de ações e fizessem parcerias e alianças sem, necessariamente, nomeá-las ou enquadrá-las como ações do Mandato, sobretudo, naquele momento de incerteza em relação à continuidade do movimento enquanto tal. De certo modo, é possível afirmar que o movimento parecia tanto mais definido quanto mais indefinidas fossem suas fronteiras, o que, mais uma vez, torna a noção de grupo, como 
uma entidade substantiva com limites bem demarcados, pouco útil para dar conta da configuração existencial do coletivo.

Se fôssemos também pensar o Mandato por meio da clássica e um tanto obsoleta oposição dentro/fora, ficaria claro que ela seria continuamente subvertida, uma vez que o suposto exterior se tornava frequentemente o centro dinâmico das atenções e ações do Mandato. Os encontros de formação política e da constituição de uma frente democrática, realizados em Ermelino Matarazzo, muitas vezes apenas com a participação de dois ou três integrantes do $\mathrm{MC}$, frequentemente colocavam em pauta a ideia de, a partir dali, surgir uma candidatura para as eleições seguintes, isto é, haveria grande possibilidade do candidato do Mandato para vereador não ter origem no MC. Ao que tudo indica esse ponto de vista não apenas não era estranho ao movimento, como pode ser facilmente compreendido a partir da ideia cidadanista de que os representantes políticos deveriam ter um vínculo orgânico com os seus representados, o que coloca em questão a própria noção de representação política que fundamenta o conceito moderno de democracia. Assim, a próxima candidatura do coletivo poderia ser construída tanto a partir de um de seus membros como de movimentos sociais existentes na região de atuação do Mandato e a abertura do MC a esses ativistas locais não seria apenas receptiva (no sentido de que o Mandato receberia qualquer um que quisesse participar), mas seria um ideal buscado ativamente e, para isso, as reuniões de formação política e rodas de conversa com a comunidade teriam um papel fundamental. No entanto, é verdade que, em vários momentos, a preocupação com definições mais precisas ou delimitação de contornos não esteve completamente ausente nas reflexões sobre o movimento, como veremos mais adiante.

O principal assunto em pauta nas primeiras reuniões pós-eleitorais foi a avaliação da campanha, seus acertos, erros e algumas lições para uma futura candidatura. As primeiras impressões dos cidadanistas eram de que o legado da campanha tinha sido bastante positivo apesar do resultado frustrante da eleição. Quase todos reconheceram enfaticamente - como alguns já vinham fazendo em comentários ocasionais durante a campanha - que o Mandato Cidadanista fortaleceu o coletivo, promovendo a união dos raizeiros que estavam dispersos e, com isso, encorajando a retomada da Raiz. Mas se o 'fazer-junto' contribuiu para reavivar certo senso de coletividade, como vimos, - também em razão da intensa experiência emocional compartilhada -, ele, por si só, não poderia funcionar como uma força sociativa capaz de garantir a união dos correligionários de Mandato, como uma visão durkheimianamente inspirada poderia esperar. $\mathrm{Na}$ realidade, a experiência comum poderia, inclusive, ter efeitos bastante desagregadores, como 
ocorreu nas eleições municipais de 2016, que figura no imaginário dos cidadanistas como um momento de desestruturação do movimento. Para eles, o simples fato da ação coletiva importaria menos do que os modos de relação que lhe seriam constitutivos, daí a preocupação sempre presente com a forma como as pessoas se relacionavam no momento das práticas conjuntas. Assim se poderia entender como as primeiras avaliações individuais da campanha eleitoral apontaram para um saldo positivo, apesar do insucesso nas urnas, de modo que a visão da campanha eleitoral como uma derrota não emergiu simplesmente de uma constatação automática do fato de não terem conquistado a vaga na câmara federal.

Mesmo que a ideia de derrota estivesse presente no coletivo, o sentido de fracasso eleitoral teve que ser trabalhado para adquirir maior relevância e uma forma específica. Era preciso, antes de tudo, lidar com uma contradição que se encontrava na própria origem do Mandato Cidadanista e que, ocasionalmente, vinha à tona nas atividades de campanha. Trata-se da tensão, já mencionada, entre a forma dos cidadanistas pensarem a política e o que eles entendiam como imperativos e regras do jogo eleitoral. Se a política vista sob o prisma cidadanista deveria enredar paulatinamente as pessoas em um modo de existência política que transbordasse a imediaticidade do período eleitoral e o âmbito das instituições oficiais, a lógica da disputa exigia uma abordagem pensada em termos de estratégias mais ou menos eficientes para conseguir a maior quantidade de votos dentro do tempo e das possibilidades dadas (número de pessoas, recursos materiais etc.). Por mais que essa lógica tenha sido reconhecida como sintomática da degradação das instituições políticas vigentes e por mais que os cidadanistas tenham sempre nutrido uma grande desconfiança para com a ideia de que bons fins pudessem ser alcançados por meios viciados, eles reconheciam que era preciso compor com essa realidade, fazendo-lhe concessões e, tanto quanto possível, promovendo os ideais políticos do coletivo. E não apenas se convenceram da necessidade de atuar de acordo com as regras do jogo, como em muitos momentos se mostraram entusiasmados com o desafio de maximizar as chances de vitória por meio de ações de amplo alcance, como intervenções em espaços públicos, distribuições de impressos entre outras. Mas para se chegar à avaliação retroativa do processo eleitoral como um caminho na direção do fracasso, foi preciso mais que o mero resultado das urnas e, para isso, a intervenção da coordenação de campanha nas primeiras reuniões de avaliação cumpriu um papel decisivo.

Embora a campanha tenha tido como um dos seus traços mais característicos a abertura para as iniciativas e protagonismo da equipe executora das ações (codeputad@s e voluntári@s), o Ivan sempre cumpriu um papel, reconhecido coletivamente, de coordenador geral, reunindo as pessoas, 
estimulando a manutenção de uma agenda de atividades, suscitando o autorreflexão e a autoavaliação contínua do desempenho dos agentes etc. Mas o que me pareceu mais importante nesse momento foi o seu papel de mediador entre o universo da política oficial (com seus números, orçamentos, análises de conjuntura, pesquisas sobre o comportamento do eleitor, intercâmbios e alianças outros candidatos) e o universo do Mandato com seu propósito de colocar em prática os princípios de uma política mais inclusiva, solidária, humanista, ou seja, uma política que muitos costumam chamar, até com certo desdém, de idealista. A ação coordenativa do Ivan contribuiu para que os cidadanistas se situassem e se orientassem no universo da política eleitoral e a forma como eles responderam às suas intervenções durante e após a campanha mostrou que a sua atuação estava investida de grande prestígio e legitimidade e - tendo em vista que a eleição tinha um componente tensivo fundamental -, a aquiescência deliberada dos meus interlocutores ao seu pragmatismo eleitoral não deixou nenhuma dúvida quanto ao caráter decisivo da sua participação.

Os primeiros encontros pós-eleição, começaram com depoimentos sobre aspectos positivos da experiência do mandato, otimismo que logo foi contestado pelas intervenções de Célio e Ivan, que defenderam enfaticamente a necessidade do reconhecimento coletivo da derrota. Para dar consistência a essa visão derrotista elencaram alguns elementos que, durante a campanha, eram reiteradamente reconhecidos como parâmetros que poderiam garantir o sucesso em uma eleição. Para eles, a principal evidência de que a campanha teria sido um grande fracasso foi a quantidade de votos conquistados pela chapa (9074 votos), muito aquém do necessário para ocupar uma cadeira na câmara, mas pior seria a frustração resultante da expectativa que superariam a marca dos 50 mil votos. A interpretação do alcance de apenas um quinto desse montante como um grande fracasso só foi possível a partir do reconhecimento prévio de uma relação de equivalência entre uma grandeza numérica e a qualidade do trabalho ou do empenho dos agentes que, diga-se de passagem, acreditavam estar dando o melhor de si em uma conjuntura política bastante desfavorável. É importante adicionar que durante a campanha foram sendo construídos acordos sobre quais práticas conduziriam ao sucesso eleitoral e essa demarcação de tipos ou modos de ação foi o que permitiu, nessas reuniões, um olhar retroativo sobre todo o processo eleitoral para elencarem o conjunto de fatores causadores do seu fracasso. Nesse sentido, as sugestões comuns a algumas análises dos cidadanistas de que o número pequeno de votos foi resultado de um contexto político que favorecia candidaturas da direita ou da esquerda identitária, foram consideradas, pela coordenação da campanha e alguns dos cidadanistas mais participativos, insuficientes ou pouco relevantes para explicar o insucesso coletivo. Ficou bastante claro nesses discursos que colocar um peso demasiado 
no contexto político eximiria de responsabilidade os agentes envolvidos, podendo acarretar consequências bastante indesejáveis. O que me parece mais importante nessa forma de atribuição causal é o que ela revelou acerca de uma outra preocupação subjacente com o controle e com o estatuto da agência dos sujeitos. Pois se os elementos que determinavam o sucesso eleitoral não pudessem ser controlados pela ação dos agentes e dependessem, sobremaneira, das forças irrefreáveis e imprevisíveis do cenário político mais amplo, não pareceria haver muito o que dizer e o que fazer para transformar a derrota daquela eleição em vitória na seguinte. Por outro lado, se fosse possível identificar as variáveis que determinariam o sucesso eleitoral e atuar sobre elas, a vitória dependeria, tão somente, da capacidade de executarem ações que incidissem diretamente sobre esses fatores determinantes. E mesmo que houvesse um gap entre o conhecimento dos fins e os meios empregados, ainda assim persistiria a ideia de que o sucesso estaria nas mãos dos agentes e que o planejamento e a ação realizados com empenho e antecipação praticamente assegurariam a vitória do coletivo no pleito seguinte. Essa visão também ajudou a construir imagens temporais específicas de um passado, presente e futuro e estabelecer um sentido de continuidade entre elas, de modo que o passado pôde ser entendido como uma etapa de aprendizado necessária para alcançar o êxito eleitoral futuro e os agentes, transformados por essa experiência, agora estariam munidos de um 'saber-fazer' que, bem realizado (no tempo certo, com disponibilidade de recursos financeiros mínimos, pessoas etc.), garantiria-lhes um resultado completamente distinto. Isso lhes permitiu diminuir as incertezas e restituir a confiança em relação ao futuro bem como pensar a noção de fracasso distanciando-a da acepção, sugerida em um comentário isolado, de perda de tempo. Era preciso juntar os cacos e tirar lições do passado, para, o quanto antes, germinar as sementes que foram plantadas naquela eleição a fim de que pudessem colher os frutos da vitória na eleição seguinte.

É importante chamar a atenção para o fato de que, embora a coordenação da campanha não tivesse feito grandes esforços para estabelecer os termos sob os quais era realizado o debate político - pois eles radicavam, em sua maioria, nas categorias acionadas nas práticas cotidianas dos agentes -, os valores que lhes eram atribuídos prestavam-se, comumente, a embates e modificações dos cidadanistas. A noção de fracasso e sucesso eram para todos ideias-chave na simbólica da eleição. Mas quando entravam em jogo os valores atribuídos, por exemplo, ao alcance de um montante de votos ou ao revigoramento dos laços coletivos, foi necessário mobilizar uma série de procedimentos retóricos para que pudessem entrar em acordos. Essas operações não se atinham apenas ao discurso verbal (ações de campanha ou um gráfico mostrando a distribuição dos votos pelos distritos 
eleitorais também entravam nessas operações), o que aproxima essas práticas discursivas da definição de retórica social de Herzfeld como "qualquer sistema simbólico utilizado como um instrumento de persuasão - ou, como poderíamos dizer hoje, utilizado para efeitos performáticos" [...] (HERZFELD 1996: 139). Isso não quer dizer que as práticas discursivas desses agentes serviam para mascarar intenções ou interesses dissimulados, pelo contrário, eles se encontravam totalmente enredados nas retóricas que acionavam.

Em um estudo etnográfico realizado em uma campanha eleitoral de um candidato a vereador em um município do Estado do Rio de Janeiro, Goldman e Silva (1999) mostraram a importância da ideia de retórica social para o exame das lógicas presentes nos discursos que buscavam explicar a derrota eleitoral de um candidato que, a princípio, era dado como vitorioso. Essa abordagem permitiu aos autores colocar no campo da retórica algo que, sob outra ótica, poderia parecer uma contradição pura e simples: o fato dos agentes terem apresentado as mesmas razões, tanto para prever a vitória do candidato, quanto para, posteriormente, explicar a sua derrota.

Entre os cidadanistas, elementos que eram apresentados, antes das eleições, como diferenciais que impulsionariam o MC em direção à vitória, também passaram a ser elencados como causadores de sua derrota após a eleição. Até a linguagem utilizada (baseada na promoção de princípios como empatia e solidariedade), que antes supunham ter o poder de conquistar corações $e$ mentes, também foi, em parte, responsabilizada pelo resultado, visão muito bem sintetizada na fala decidida de Eduardo: perdemos porque falamos de amor. O mesmo poderia ser dito em relação ao diagrama com o modelo de organização do MC, que deixou de ser considerado uma bela síntese de sua proposta de democracia participativa para se transformar em uma bolinha que não comunica. Mas, como acabamos de ver em relação à consolidação de uma visão derrotista, essa mudança significativa dos termos do jogo político não se fez naturalmente e foi preciso mobilizar outros elementos para a constituição de um conjunto retórico persuasivo.

\subsection{Oficina Cidadanista: de volta aos trabalhos}

Em uma manhã quente de sábado do mês de fevereiro, os cidadanistas se reuniram no salão social da Paróquia Nossa Senhora do Carmo, em Itaquera, para discutirem os passos seguintes do MC, principalmente, a viabilização de uma candidatura coletiva para as eleições municipais de 
2020. Eu me detenho com mais vagar nesse encontro pois ele foi entendido como a retomada efetiva do Mandato após do encerramento das eleições e, por isso, a avaliação das eleições já não era objeto direto de discussão, como havia sido antes. Essa reunião ainda assumia maior importância pois antecedia a Teia Nacional da Raiz, ocasião em que seria decidido o futuro da associação. Com esse encontro, portanto, os cidadanistas (que também eram integrantes da Raiz) assumiam um compromisso mútuo, independente de qual fosse a decisão da Raiz nesse assunto. É bom ressaltar que meus interlocutores afirmavam, reiteradamente, que não viam diferença entre o Mandato e a Raiz a não ser pelo fato da última ter uma estrutura organizativa de nível mais abrangente que, por isso, requereria uma resolução específica sobre sua atuação nas eleições, principalmente tendo em vista a crise gerada no pleito de 2016. Como os cidadanistas viam a Raiz como em um relativo estado de inatividade (hibernação) - relativo, pois seus integrantes continuavam a atuar nos movimentos sociais como membros da Raiz -, parecia-lhes inoportuno reuni-la justamente no momento conturbado de uma eleição (seria preciso, por exemplo, uma reflexão coletiva prévia sobre a pertinência de uma candidatura, uma reavaliação da estrutura organizativa etc.). Depois, a candidatura do MC se constituiu em torno do Célio Turino por ele ter sido convidado pelo PSOL e não em virtude de um projeto gestado no âmbito das atividades da Raiz de São Paulo. Mas embora o Mandato não fosse uma ação oficial da Raiz, praticamente todos concordavam que ele era como se fosse uma ação da Raiz na prática, como não se cansavam de dizer.

Descartando logo de saída as discussões acerca do estatuto da Raiz ou da relação Raiz-MC, que já tinha sido discutida em ocasiões anteriores, a Oficina Cidadanista tinha como objeto elencar um conjunto de ações que viabilizassem eleger alguém em 2020. Seu objetivo era, portanto, assumidamente pragmático. Mas como praticamente tudo entre os cidadanistas não era exatamente o que parecia ser, com a sua ideia de pragmatismo eleitoral não poderia ser diferente. Pois o pragmatismo eleitoral reivindicado por eles não visava apenas a conquistar os votos necessários para elegê-los mas objetivava, sobretudo, estabelecer uma relação mais orgânica com as comunidades onde estariam as suas bases eleitorais (considerada condição sine qua non de legitimidade para uma candidatura cidadanista $)^{35}$, contribuindo para diminuir o fosso que, na política institucional, tem separado representantes e representados. Desse ativismo comunitário também surgiriam os integrantes da chapa da candidatura, incluindo a cabeça de chapa ou, como

35 É nesse sentido que podemos entender a sentença de Eduardo de que não faria parte de um projeto futuro que não estivesse conectado com o sentimento da zona leste, uma crítica à suposta falta de organicidade do mandato nas eleições. 
preferiam chamar, o nome na urna. Tratava-se, sem dúvida, de pensar meios efetivos e eficazes para realização de determinados fins, mas eles não poderiam ser reduzidos à lógica maximizadora (de votos) do cálculo eleitoral (definida, algumas vezes, como pescar votos). A diferença fica ainda mais clara quando vemos que, mesmo uma oficina pensada para ter objetivos claros e bem definidos, abria um grande espaço para práticas que normalmente estão associadas com o oposto disso, como veremos a seguir.

Quando cheguei ao local do encontro, uma sala para cursos e reuniões do Cifa, em Itaquera, todos já estavam sentados em suas cadeiras, dispostas em uma configuração circular, como era o costume. Ao adentrar a sala, imediatamente senti o choque entre o meu ritmo acelerado e o silêncio e a quase imobilidade corpórea dos presentes, exceto pela fala da Silvana, com um tom que me parecia muito eloquente e emocionado e que absorvia irresistivelmente a atenção de todos. Depois que eu me acomodei em uma das cadeiras que estavam no círculo, peguei o meu caderno de campo e uma caneta e fui, de imediato, advertido para, naquele momento, não fazer anotações. Terminada a fala da Silvana, a Kida me explicou que se tratava de uma roda de escuta profunda (pinakarri) e que todos deveriam apenas escutar uns aos outros, ininterruptamente, até o final de suas falas, pois nessa modalidade de escuta não tem debate e não tem contraposição.

A escuta profunda dos cidadanistas foi inspirada nas práticas de escuta associadas a inúmeros povos indígenas, mas o termo acionado pinakarri remete, especificamente, às práticas dos aborígenes Martu Mandjilidjara do deserto Great Sandy na Austrália ocidental e que foram traduzidas e incorporadas em uma metodologia (Dragon Dreaming) criada para a construção de organizações e projetos visando à sustentabilidade econômica, social e ambiental de coletivos e comunidades ao redor do mundo (CROFT 1991). A versão da pinakarri reivindicada pelos cidadanistas parte do princípio de que estamos perdendo a capacidade de ouvir o outro e tendemos a submeter o seu discurso ao nosso próprio sistema de verdades. A proposta da escuta profunda só pode ter sucesso quando assumimos as limitações da nossa sabedoria e reconhecemos que as outras pessoas podem deter saberes e perspectivas que nos libertam e nos enriquecem, o que implica, na prática, estabelecer uma relação de empatia com a fala do outro. Geralmente, nessas práticas os participantes podem iniciar um pinakarri ativando algum tipo de sinal previamente acordado, normalmente um sino ou um gongo, e a partir desse momento todos ficam em silêncio por um período de tempo, para dar voz aos seus desejos e necessidades interiores (DRAGON DREAMING BRASIL 2014:6). Outra variação, e a que aqui nos interessa, consiste em passar o bastão da palavra, ou seja, passar um objeto de mão em mão em uma roda de modo que aquele que o estiver segurando 
torna-se o portador da palavra e passa a contar com a atenção total de todos os integrantes do círculo. $\mathrm{Na}$ escuta profunda dos cidadanistas o objeto que marcava o início e o término das falas era um maracá, em alusão às rodas de conversa dos povos ameríndios, especialmente os Guarani. Antes de dar início à fala, cada um se dirigia ao centro da roda e pegava o maracá que estava sobre uma pequena mesa e que deveria ser segurado durante todo o tempo do seu discurso. Sem entrar em detalhes a respeito do conteúdo de cada uma das falas, por seu caráter confidencial e sigiloso, posso destacar algumas características bastante recorrentes nesses relatos. Em primeiro lugar todas as falas eram marcadamente subjetivas e emotivas e começavam com narrativas autobiográficas que reconstruíam as trajetórias pessoais e políticas que levaram os agentes a se encontrarem naquele projeto comum. Histórias pessoais que contribuíram para sensibilizá-los em relação à miséria e à devastação planetária e que os levaram à luta contra a desigualdade, as suas frustrações com a política institucional e a esquerda partidária, tudo isso compunha uma trama que, ao mesmo tempo, adquiria e dava sentido pleno ao modo de existência política do coletivo. Excetuando uma ou outra referência muito indireta, nada foi dito sobre as eleições passadas ou sobre a candidatura futura, pauta principal do encontro. A mudança brusca no ritmo e no tom das falas, as vozes embargadas e olhares marejados indicavam o clímax emocional do encontro e tinham, visivelmente, o efeito duplo de, ora captar os olhares da audiência, ora fazer com que alguns desviassem seus olhares para um ponto qualquer, como se demonstrassem certo desconcerto ou tentassem conter as suas próprias emoções. Mais do que produzir um sentimento geral de pertencimento coletivo, esse ritual de escuta também parece ter contribuído para criar um forte sentimento de identificação com as experiências uns dos outros e de reavivamento das próprias experiências pregressas. Esse foi um momento no meu trabalho de campo em que o ideal positivista da separação entre sujeito e objeto se mostrou, mais do nunca, uma grande quimera e o meu enredamento emocional na escuta condicionou sobremaneira o resultado dos caminhos interpretativos aqui trilhados. Se em alguns momentos no campo ficava evidente uma diferença de classe que me fazia sentir uma certa distância em relação a alguns dos meus interlocutores, a escuta suscitou em mim a sensação de que deveras partilhávamos uma mesma existência e a tensão na fala da Silvana e o meu 'frio no estômago' eram como se fossem índices corpóreos e constituintes de uma forma de habitar e sentir um mundo em comum. Pouco antes de chegar a vez da minha fala eu planejava me restringir aos grandes acontecimentos que me levaram à escolha da temática e dos sujeitos da pesquisa, mas no fim do primeiro minuto eu já tinha abandonado completamente o script, como se uma força tivesse me afastado da superficialidade protocolar da academia e me arrastado em direção ao 
âmago das minhas motivações mais íntimas, dos meus medos, da grave situação que ameaçava a subsistência da minha família (resultado direto da crise econômica do país) etc. Era como se o ritmo e o conteúdo do meu discurso fossem gerados a partir de uma tensão que atravessava os corpos e que era refratária a qualquer tentativa de controle consciente. A mudança no tom das vozes e as falas embargadas, facilmente percebidas nos meus interlocutores em grandes momentos de tensão, se impuseram igualmente a mim ao verbalizar memórias e eventos investidos de grande valor simbólico-emocional. E assim, cada uma das manifestações individuais foi marcada em algum momento por elementos autobiográficos ou por reflexões gerais sobre como os cidadanistas se sentiam e se situavam em relação aos companheiros de luta, à política e ao mundo.

Se a escuta profunda pôs em evidência a autoria individual do discurso, colocando essa prática, quase que naturalmente, em oposição à dinâmica de uma roda de discussão típica, é preciso cuidado para não reduzir as duas formas discursivas ao dualismo indivíduo/sociedade, que alicerça nossos sistemas de entendimento. Pois se o autor, com sua voz solitária e, marcadamente, autobiográfica, foi reconhecido, destacado e singularizado, a escuta compôs um quadro heteróclito que costurava o eu e o outro de uma forma profunda e nada trivial. Tudo leva a crer que a imersão da escuta também funcionou como uma espécie de atalho para a construção de vínculos de confiança que, idealmente, só se estabeleceriam a partir de relações de afeto e conhecimentos interpessoais, elementos que parecem centrais na escuta profunda (mesmo com sua duração temporal reduzida). Vale lembrar os debates e as queixas acerca das dificuldades em estabelecerem vínculos de confiança nas relações em meios digitais (cap.2), uma concepção que, ocasionalmente, era reiterada nos encontros.

Outro aspecto que talvez merecesse maior atenção e que não será aqui objeto de análise detalhada é o forte caráter de contágio e propagação do ritual de escuta. Ficou claro que a primeira fala estabeleceu, na prática, um modelo discursivo - para além das duas únicas regras explicitamente formuladas de não interromper e não se contrapor - que orientou consideravelmente as falas seguintes a ponto de, em certa altura, um dos falantes avisar, logo no começo da sua fala, que assuntos familiares teriam um espaço reduzido em seu discurso (indo na contramão de todos que o antecederam). Se todos eram livres para falar o que quisessem, não ficaria bem, após um discurso longo, imerso em uma notável densidade emotiva, alguém fazer uma síntese informativa típica dos melhores currículos lattes. O que chama a atenção também para a capacidade das primeiras falas de estabelecerem, ainda que de modo grosseiro, um parâmetro temporal, mais especificamente, uma noção geral de que há uma duração mínima adequada para uma fala profunda. 
Mas ultrapassado certo limite, o discurso emocionado pareceu ter o efeito de suspender o tempo, de modo que sua duração passaria a ser demarcada a partir de sua própria dinâmica interna. E, deste modo, a escuta ultrapassou o tempo previsto no planejamento para o dia, ocupando toda a primeira parte da oficina, que só foi retomada após o intervalo para o almoço.

O encontro foi retomado, após o almoço, com o Ivan apresentando uma proposta de readequação do cronograma em razão da escuta ter se estendido para além do esperado e, em seguida, com alguns informes gerais. Essa segunda parte do encontro começou com uma breve discussão acerca das resoluções da última reunião com as deliberações sobre o lançamento de uma candidatura baseada territorialmente na zona leste de São Paulo e sobre a decisão de uma filiação de parte do coletivo ao PSOL. Questões sobre a relação entre o MC e a Raiz foram trazidas para a discussão, mas logo o Ivan ponderou que isso ficaria para a Teia Nacional da Raiz e que a oficina tinha o objetivo bastante pragmático de elencar um conjunto de ações para serem implementadas nos meses seguintes. Nesse momento a Kida tomou a palavra e pediu para que os presentes se dividissem em dois grupos, atribuindo alternadamente o número um e dois a cada um de nós. Aqueles que tivessem o mesmo número deveriam se reunir para realizar a atividade proposta. Eu fui para o grupo da Fernanda, Jopa, Kida e Sônia. O Jopa e eu cortamos algumas folhas de sulfite ao meio, horizontalmente, e distribuímos essas metades entre todos, enquanto que, em uma lousa, a Kida escreveu cinco colunas, respectivamente intituladas: o quê (ações); por quê (justificativa); desafios; como (procedimentos); quando? A tarefa dos grupos era pensar ações que preenchessem cada um dos requisitos dessas colunas e que pudessem ser implementadas em, no máximo, seis meses e, no final, deveriam escolher uma das ações discutidas para ser apresentada e discutida com todos. Sentados em um círculo dentro da sala, cada integrante do meu grupo falou sobre as ideias que tinha em mente, enquanto o outro grupo fez o mesmo em outro espaço do Cifa. As ideias apresentadas pelos cinco integrantes grupo foram as seguintes:

(1) Grupo de acolhimento às vitimas de violência (Jopa): o Jopa propôs montarem um grupo de acolhimento de vítimas de violência com espaços de conversa e assistência médica e jurídica. A ideia também seria tirar desses grupos pautas de ações propositivas. O Jopa justificou brevemente a sua escolha em razão do quadro de violência que estávamos vivendo e que tendia a se acirrar com o governo eleito. 
(2) Ações de modificação e intervenção na paisagem (Thiago): propus que fossem feitas intervenções na paisagem dos bairros com reforma de praças, plantio de árvores, jardinagem ou outras ações do gênero. Justifiquei dizendo que essas ações costumavam ser muito bem recebidas pela população e deixavam marcas que poderiam servir como vitrine para as eleições municipais de 2020 (tendo em vista que o objetivo dessas ações era justamente viabilizar uma candidatura para 2020).

(3) Escolher o representante do Mandato (candidatura oficial) para as eleições (Sônia): para a Sônia seria importante, já nos próximos meses, organizarem-se em torno de uma liderança social natural para viabilizarem a sua candidatura.

(4) Economia paralela e moeda social (Kida): a ideia da Kida era fortalecer o comércio e a economia local com uma moeda social. A ideia incluiria atividades de divulgação para as pessoas e ações de doação, troca e compartilhamento.

(5) Sarau cidadanista (Fernanda): a Fernanda propôs promover um Sarau que tivesse como objetivo se tornar uma referência de cultura entre os moradores do bairro.

(6) Jornal Microterritorial de WhatsApp (Fernanda): a Fernanda sugeriu a criação de um listão de notícias semanais de um microterritorio. O listão seria constituído majoritariamente de notícias locais e cotidianas (até mesmo um correio elegante) e, para isso, os próprios moradores contribuiriam com o registro e seleção de notícias.

(7) Rede de Solidariedade (Fernanda): a terceira ideia da Fernanda era montar uma rede de solidariedade que conectasse as pessoas que precisassem de algum tipo de ajuda com aquelas que pudessem ajudá-las. Deu o exemplo de quilombolas, em risco de perder o seu território, que poderiam ser auxiliados por advogados voluntários a partir da intermediação de uma rede.

Como achamos difícil escolher a melhor ideia - e nunca é demais lembrar que o coletivo sempre fez críticas reiteradas à noção clássica de escolha - a Fernanda apresentou todas as sugestões, com exceção da proposta da Sônia por acreditarmos que ela necessariamente seria 
contemplada como decorrência da implementação de qualquer uma das propostas. Representando o seu grupo, o Ivan apresentou duas propostas: (1) Um mutirão de revitalização de espaços públicos com atividades culturais; (2) A promoção do plano do bairro (uma iniciativa da sociedade civil prevista no plano diretor do município). O Ivan completou dizendo que a zeladoria é uma preocupação muito presente em pesquisas feitas com a população e chamou a atenção de todos para o fato de que ninguém ali estava falando diretamente de candidatura, pois o candidato sairia naturalmente dessas ações. Das seis propostas do meu grupo, foram escolhidas a proposta de intervenção na paisagem e o sarau cidadanista, deixando o plano de bairro e o jornal territorial como ações paralelas que seriam implementadas, possivelmente, mais adiante. Logo todos perceberam a grande convergência entre as ações sugeridas e que a decisão seria menos função de uma escolha entre propostas prontas fechadas sobre si como objetos estanques - do tipo: ou (1) ou (2) ou (3) ou (4) - do que fazer com que várias propostas habitassem conjuntamente o interior de uma ideia mais ampliada - $\left(1^{*}\right.$ e $\left.\left\{2^{*}, 3^{*}, 4^{*}\right\}\right)$-, sendo que cada uma das propostas originais foi de algum modo transformada para compor o novo arranjo. Assim, o mutirão foi ampliado para receber: o sarau cidadanista (que agora teria um formato muito mais aberto); venda de artesanato, orgânicos $\mathrm{e}$, talvez, uma feira de trocas (buscando conciliar a ideia de economia paralela com o formato de uma feira); intervenções na paisagem (mas se distanciando da ideia de jardinagem original em favor de intervenções menos dependentes de manutenção contínua); e, por fim, um espaço para acolhimento temático com atendimento social de advogados, psicólogos etc. (podemos ver que aqui houve a aproximação e a transformação das ideias do grupo de acolhimento, do Jopa, com a ideia da rede de solidariedade, da Fernanda).

Depois foram discutidos os outros requisitos para viabilizar a ação como os desafios, os procedimentos, o local (alguma praça), a data (no mês de abril) etc. Nesse momento ficou evidente a preocupação com o envolvimento e a participação dos moradores da região onde seria realizada a ação e com a capacidade do coletivo realizar com sucesso esse conjunto de ações. Isso os levou a discutirem a distância existente entre o plano (teoria) e a prática e reafirmarem, como fizeram muitas vezes, a necessidade de se aprender fazendo, uma concepção que era muito comum ser reiterada nos momentos de planejamento e de ações conjuntas. Ao serem perguntados sobre a disponibilidade para participarem da ação, todos levantaram prontamente as mãos e, em seguida, dividiram-se, voluntariamente, nos dois grupos de trabalho sugeridos, um grupo local (onde foram 
alocados aqueles que tinham mais disponibilidade para atuarem na zona leste) e um grupo operacional (que foi constituído por aqueles que residiam em outras regiões).

\subsection{Teia Nacional da Raiz}

Uma semana após a oficina cidadanista, foi realizada, em São Paulo, a $10^{\mathrm{a}}$ Teia Nacional da Raiz, reunindo os integrantes da Raiz de todo o país. O encontro foi realizado em dois dias, sendo o primeiro dia em Itaquera, zona leste da cidade, e o segundo no Jardim Paulista, na região oeste. Essa Teia foi cercada de muita expectativa e se revestia de grande importância por representar um momento chave de definição acerca da continuidade e dos rumos da Raiz após um longo período de pouca atividade.

Além dos cidadanistas de São Paulo, estavam presentes integrantes da Raiz do Rio Grande do Sul, Ceará e Pernambuco (um total de 18 pessoas) e outros participaram por meio do canal da Raiz na plataforma Youtube, que apresentou problemas na transmissão na primeira parte do encontro. A seguir, farei um resumo geral do evento destacando apenas alguns pontos que me pareceram pertinentes para a discussão aqui travada.

A primeira parte do encontro de Itaquera foi dedicada a uma roda de escuta profunda, como na oficina realizada na semana anterior. Entretanto, a dinâmica dessa escuta foi bastante diversa da primeira, marcando ainda mais a especificidade daquela. A pinakarri da Teia consistiu basicamente em uma roda de apresentações, com uma descrição sintética da atuação de cada um, em alguns casos, precedida de um breve histórico de militância. Tudo isso condensado num espaço de tempo de três minutos (com tolerância de mais dois minutos), duração que foi delimitada pelo cair da areia de uma ampulheta. Como era de se esperar, esse momento foi bem menos intimista do que foi na Oficina Cidadanista, em que todos falaram com profundidade dos seus sentimentos e de suas vidas pessoais (para muito além da sua atuação nos movimentos sociais). Como no último encontro, não fiz anotações das falas, apenas observei e me apresentei aos presentes, aproveitando a oportunidade para falar sobre a minha pesquisa para aqueles que não a conheciam. No decorrer de suas falas, os cidadanistas das outras regiões do país destacaram alguns dos muitos ativismos em que estavam engajados, dentre os quais: 
(1) A atuação dos integrantes do círculo da Raiz de Porto Alegre no estabelecimento de uma rede de apoio a retomadas indígenas e junto a movimentos de mulheres (Ocupação Mirabal, rede de apoio a vítimas de violência doméstica e um movimento pela legalização do aborto). (2) $\mathrm{O}$ apoio à luta por moradia dos integrantes da Raiz da cidade de Cotia por meio de assistência jurídica.

(3) O trabalho socioambiental em prol do desenvolvimento agrosilvopastoril sustentável (que inclui ações em favor do acesso à água e no combate à desertificação do semiárido) junto a agricultores e comunidades indígenas, em Pernambuco.

(4) Uma ação de resgate da cultura xukuru no Ceará.

(5) Outras ações incluíam: a participação na elaboração de um curso sobre a auditoria cidadã da dívida pública e ações em prol dos direitos humanos, como a participação num comitê antitortura.

Parece-me importante chamar atenção para o fato de que, embora todos compreendessem os seus ativismos como parte da sua atuação como integrantes da Raiz - Movimento Cidadanista, ainda assim persistia a ideia de que a Raiz estava pouco ativa ou mais ou menos parada, como disse Ricardo, um discurso muito próximo ao dos cidadanistas de São Paulo, como mostrei aqui. E, curiosamente, essa visão persistia concomitantemente à ideia de que os círculos territoriais (como o de Porto Alegre) dos quais faziam parte encontravam-se em plena atividade. Quando essa contradição é vista mais de perto, ou seja, em suas situações de enunciação concretas, é fácil constatar que a noção de paralisia e inatividade era acionada quase sempre e com mais ênfase quando a Raiz era pensada em uma dimensão mais ampliada, nacionalmente. Não é que não houvesse referências ocasionais à necessidade de retomada de ações no âmbito mais local - como era o caso dos membros do pequeno círculo de Itaquera que, não raro, diziam que suas atividades no bairro precisavam ser retomadas; mas, ao contrário da ideia de uma Raiz paralisada, não colocavam em causa o futuro da ação coletiva nesse nível mais local (a sua retomada estava quase garantida, sendo apenas uma questão tempo). Quando nas discussões do MC, questões sobre quem eram e o que queriam entravam em pauta, elas eram geralmente remetidas às imagens de uma articulação coletiva de nível mais amplo, já que a própria constituição do Mandato indicava que, de um jeito ou de outro, o cidadanistas de São Paulo continuariam se articulando e atuando politicamente com as mesmas bandeiras de luta e os mesmos princípios de sempre. É por isso que a pauta do primeiro dia de encontro era tão esperada e parecia tão fundamental, afinal de contas, o 
que era exatamente esse movimento político e qual o sentido de pensá-lo como uma organização política de âmbito nacional?

$\mathrm{Na}$ segunda parte do encontro o Ivan tomou a palavra e pediu para os presentes se dividirem em três grupos para discutirem a seguinte questão, que escreveu em uma lousa e leu em voz alta: $O$ que é a Raiz e o que nos une como grupo: princípios, valores e identidade. Depois da discussão, um representante de cada grupo deveria fazer um relato para todos sobre as conclusões do coletivo. Os grupos foram divididos aleatoriamente e eu fiquei no grupo três com o William, o Gabriel, a Marilu e o Ricardo.

O William iniciou a sua fala dizendo que o que unia o coletivo era o manifesto da Raiz, os princípios contidos na Carta Cidadanista. Disse que as eleições de 2016 quebraram a Raiz em razão de alguns apenas vê-la sob uma perspectiva partidária e, a partir de então, a Raiz se dispersara, sobretudo quando interrompeu a coleta das 500 mil assinaturas para legalização partidária. Mas também lembrou que cada um, na sua prática, continuava desenvolvendo um trabalho afinado com os princípios cidadanistas.

O Gabriel disse que o que os uniu não foi a prática, mas o sonho do que queriam ser. E completou dizendo que o que os movia não era exatamente os princípios da Carta Cidadanista, mas a busca por eles. Por último, falou que a marca do movimento Raiz era a horizontalidade e a crítica ao capitalismo e à sua versão desenvolvimentismo.

A Marilu também chamou a atenção para os princípios, dizendo que o Ubuntu estava introjetado no modo de pensar do coletivo. Disse que todos que estavam ali compartilhavam uma cosmovisão e aqueles que não compartilhavam acabaram saindo. A Raiz seria, para ela, um coletivo contra-hegemônico onde era possível experimentar movimentos e momentos de solidariedade, ao contrário da máquina de capitalismo que reproduziria modos nocivos de se relacionar.

Para o Ricardo, os princípios implicam, necessariamente, uma não institucionalidade formal, já que esta atuaria contra a vitalidade do movimento na medida em que seria sempre burocrática e hierárquica. Eu fiz um breve comentário à fala do Ricardo dizendo que a institucionalidade precisaria ter alguma abertura para ser definida e reconfigurada pela prática e pelas ações dos movimentos senão ela poderia perder a vitalidade e fechar-se sobre si. Nesse ponto da conversa, o Ricardo chamou a atenção para a necessidade de diluírem a separação entre princípios e práticas que ainda estava muito presente em várias discussões do coletivo.

Como já tínhamos ultrapassado o tempo combinado e precisávamos fazer uma síntese para apresentar para os integrantes dos outros grupos na sala de reuniões, munido de papel e caneta, 
sugeri fazermos um resumo do que foi discutido. Inesperadamente, pediram para que eu fosse o orador do grupo, convite que - com alguma hesitação - aceitei, com a condição de que eu fosse complementado e ajudado pelos demais durante a minha fala. De volta à sala de reuniões, todos os integrantes dos grupos se uniram, sentados em cadeiras arrumadas em um grande círculo, enquanto que os oradores dos grupos foram, um a um, para a frente de um laptop (que fazia a conexão com outros membros da Raiz que estavam online) $)^{36}$ para falar sobre o que tinha sido discutido nos grupos. Com um resumo na mão, comecei a apresentar as conclusões do meu grupo e, no final da minha fala, os demais foram, um após o outro, complementá-la, incluindo alguns pontos que ficaram fora da minha síntese. Os representantes dos outros grupos foram em seguida apresentar as suas sínteses e, sem entrar nos pormenores de cada apresentação, todos convergiram de forma bastante notável em dois pontos, intimamente associados. O primeiro é a grande importância conferida aos princípios contidos na Carta Cidadanista. Depois, foi a preocupação em colocar em prática tais princípios nas suas ações de militância e em favor da transformação da realidade política e social do país.

Embora os cidadanistas reconhecessem tacitamente que havia uma base comum (que ia muito além das suas afinidades político-ideológicas, associadas comumente à esquerda) que lhes conferia o sentimento de que faziam parte de um projeto coletivo ou até mesmo de que compartilhavam um modo de 'ser-no-mundo', nem tudo se mostrou tão simples quando entrou em debate o diálogo da Raiz com a institucionalidade, quando o que estava em questão era o relacionamento da Raiz com os partidos e o sistema político institucional, assunto que já foi objeto de conflitos com efeitos bastante desagregadores. $\mathrm{O}$ teor polêmico do assunto se mostrou no mesmo momento em que o Ivan propôs a discussão, quando, de imediato, foi inquirido pela Marilu, cidadanista de Porto Alegre: A gente vai discutir a Raiz como movimento ligado a partido político ou como um movimento ligado ao PSOL? Tensão que também ficou clara na fala seguinte do Gabriel: em primeiro lugar não quero brigar com ninguém e eu estou aberto \{à discussão\}.

Alguns cidadanistas, principalmente, do nordeste e sul logo externalizaram a sua frustração com a não institucionalização partidária do movimento e até cogitaram aproveitar o registro partidário do $\mathrm{PPL}$ - que estava em processo de fusão com o $\mathrm{PC}$ do $\mathrm{B}$-, o que se viu, mais tarde, não ser legalmente viável. Quase todos os presentes defenderam a necessidade do movimento atuar na

36 O encontro podia ser assistido remotamente por meio do canal da Raiz no YouTube $<$ https://www.youtube.com/channel/UCorm0TAWhF0gd8avH22u1XQ>. Entretanto, a interação com a plataforma e os ciberagentes assumiu uma importância visivelmente secundária na Teia, inclusive, partes do encontro não puderam ser assistidas online em razão de problemas técnicos. O mesmo pode ser dito em relação às mensagens dos participantes que eram lidas muito rapidamente e raramente tinham efeitos perceptíveis na discussão. 
arena político-institucional - e a única voz que disse não ver essa necessidade também não fez oposição à ideia -, já que acreditavam que nela haveria instrumentos indispensáveis para mudanças substantivas na sociedade e que, uma vez eleitos, poderiam transformar as formas de fazer política nesses espaços. Então restava a questão de saber como fazer isso para não repetirem os erros que tanto desgaste causou ao coletivo nas eleições em 2016. Todos concordavam que não deveria haver mais espaço para alianças com partidos tradicionais, que sempre atuaram contra os direitos da população e contra os princípios expressos na Carta Cidadanista e o PSOL parecia-lhes a alternativa mais próxima da política que defendiam ou, pelo menos, a opção menos ruim. Como vimos no capítulo 2 em relação à Raiz de São Paulo, boa parte dos cidadanistas achavam o PSOL uma burocracia centralizadora e com forte inclinação autoritária (sobretudo aqueles que participaram da campanha da Erundina), embora outros o concebessem como uma organização horizontal e democrática, sempre aberta a iniciativas políticas de inspiração libertária e socialista, como a da Raiz. A maior parte dos cidadanistas de fora de São Paulo também mostrava grande desconfiança com relação ao Partido Socialismo e Liberdade e temia que a entrada da Raiz no PSOL resultasse em uma absorção total a ponto de sua estrutura centralizadora colocar em xeque a sua autonomia e impedir a realização prática dos seus princípios. Nenhuma das opções que se desenhavam no horizonte pareciam satisfazer os presentes: pois se escolhessem permanecer fora do PSOL (e do mundo político institucional) para manter sua independência, perderiam a chance de utilizar poderosos instrumentos para transformação política (e tinham a convicção de ter respostas genuínas para a crise social que assola o país) e arriscariam cair na armadilha da imobilidade e da irrelevância política. Por outro lado, se entrassem no PSOL como uma corrente, possivelmente teriam que se submeter a regras partidárias contrárias aos seus princípios e ainda correriam o risco de sucumbir à lógica perversa da disputa partidária. Mas se, à primeira vista, a política dos politicos parecia exigir a submissão dos sonhos da Raiz à realidade dura das alternativas infernais, os cidadanistas também tinham uma habilidade singular para sujeitar tais alternativas à potência criativa dos seus arranjos coletivos. E assim, foram desenhando outra proposta que já tinha sido esboçada na penúltima reunião dos cidadanistas de São Paulo, antes da Teia. Mas o que chama atenção é que ela não foi apresentada imediatamente, como uma proposta pronta para ser submetida à votação, mas ela foi ressurgindo paulatinamente, a partir de alinhamentos progressivos em torno de determinadas questões, como propunha o Consenso Progresso. A seguir, destaco alguns pontos do longo debate que começou no primeiro dia e se estendeu pelo segundo, para mostrar a dinâmica de funcionamento do Consenso Progressivo na prática. 
$1^{\circ}$ Foi reiterado (ponto incontroverso) que a Raiz deveria se fortalecer e crescer como movimento social, a sua dimensão mais importante, independente de qualquer decisão.

$2^{\circ}$ Apesar de quase todos acharem que o ideal seria a Raiz ter um registro partidário, a ideia de constituírem um partido foi descartada por unanimidade (ao menos na atual conjuntura) em virtude de uma impossibilidade prática (não foram bem sucedidos na coleta de assinaturas). Também não era viável adotar o registro de outro partido (por motivos legais).

$3^{\circ}$ Quase todos defenderam a necessidade de ocuparem espaços na política institucional e, portanto, de participarem de eleições. Apenas um dos presentes relatou não estar convencido desta necessidade, mas também não se opôs à ideia, ou seja, não concordou, mas aceitou.

$4^{\mathrm{o}} \mathrm{A}$ aproximação com o sistema partidário deveria ser com apenas uma sigla para eliminar a possibilidade de alianças indesejadas, como já ocorreu antes. Nesse ponto, houve uma discordância, com o argumento de que em regiões diferentes do país outros partidos poderiam ter uma atuação mais alinhada com os princípios da Raiz. Os argumentos que falavam sobre o risco em liberarem as alianças foram suficientes para aceitação da proposta (a aceitação assumiu o sentido de abrir mão de um posicionamento para permitir uma solução satisfatória para o problema em discussão, evitando um impasse).

$5^{\circ}$ A sigla escolhida seria o PSOL por terem maior afinidade político-ideológica com o partido, em comparação com outras siglas. Apesar das críticas ao PSOL, ninguém discordou da ideia de que a sigla era a melhor (ou menos ruim) comparativamente, com uma ressalva de que a atuação do partido Unidade Popular, em Porto Alegre, parecia mais horizontal do que a do PSOL.

$6^{\circ}$ Alguns não concordaram com a ideia de entrismo no PSOL e descartaram a possibilidade de suas filiações ao partido, principalmente pelo risco de perderam a autonomia em uma instituição vista por eles como autoritária e centralizadora. A discussão se encaminhava para um impasse. 
$7^{\circ}$ Em resposta a discordâncias inconciliáveis em relação à entrada no PSOL, foi sugerido que só uma parte dos integrantes da Raiz se filiasse ao partido, possibilidade que já tinha sido levantada nos encontros em São Paulo. Essa proposta diminuiu a divisão em torno do assunto, mas ainda havia hesitação por haver dúvidas em relação a como isso funcionaria.

$8^{\circ}$ Foi proposto que a Raiz-movimento teria autonomia absoluta em relação à Raiz-partido (corrente no PSOL) e nenhuma decisão tomada no âmbito do PSOL seria válida para toda a Raiz. Essa proposta tornou a anterior aceitável para parte dos que ainda estavam reticentes, mas ela precisou ser explicitada e complementada pela seguinte.

$9^{\circ}$ A resolução final aprovada no última dia de debates foi: que o braço da Raiz dentro do PSOL (dimensão-partido) ficaria subordinado à sua dimensão-movimento, cuja estrutura incluiria todos os integrantes da Raiz, incluindo os não-filiados ao PSOL. O que significa que a atuação da Raiz-partido no PSOL seria determinada por uma instância que a ultrapassaria e englobaria. Inclusive disputas por cargos eleitorais seriam decididas nessa dimensão-movimento.

$10^{\circ}$ A aproximação com o PSOL teria um caráter experimental e sua continuidade deveria ser referendada no encontro nacional do ano seguinte. Essa última proposição foi muito bem recebida pelos presentes, incluindo dois que se mostravam céticos à entrada no PSOL.

O aprofundamento e sistematização da discussão dos últimos quatro pontos e a decisão, propriamente dita, aconteceram no segundo dia da Teia, mas esses pontos já haviam sido apresentados ou debatidos no dia anterior, embora não tivessem recebido atenção mais detalhada. Isso permitiu que os cidadanistas pensassem com profundidade sobre o assunto, já que para mim estava claro que, em certos momentos, a aceitação de algumas proposições foi bastante hesitante e influenciada pelos ânimos coletivos ou mesmo por interpelações diretas, como quando o Vermelho perguntou ao Wellington se, com a proposta apresentada, ele não mudaria de opinião. Ao final, três cidadanistas apresentaram discordância em relação à proposta de resolução final e as suas posições foram resumidas nos seguintes termos:

(1) Não concordo, vou focar nas minhas atividades \{de militância\}.

(2) Fico na dimensão do movimento só, me resguardo a fazer o que sempre fiz. 


\section{(3) Eu atuarei na dimensão-movimento e respeito a decisão.}

É importante sublinhar que não houve qualquer oposição à resolução, mesmo que três cidadanistas tenham deixado explícitas as suas discordâncias pessoais, postura adotada, sem dúvida, graças à possibilidade de continuarem atuando na Raiz sem a necessidade de filiação ao PSOL. Isso ficou claro quando a proposta de entrada no PSOL como corrente foi apresentada de forma crua e direta (Vejo sim, em São Paulo, a possibilidade de sermos uma corrente do PSOL), logo no início desse debate. Colocada dessa forma, essa possibilidade foi imediatamente rechaçada, a ponto de um dos cidadanistas dizer, logo em sequência, que não continuaria na Raiz se ela entrasse como corrente do PSOL.

É forçoso reconhecer que a esquematização desse debate aqui apresentada, acaba deixando de lado elementos (nuances argumentativas, estratégias retóricas etc.) que, sem dúvida, também foram importantes para a condução do Consenso Progressivo. Entretanto, acredito que essa simplificação se justifica diante do objetivo modesto deste trabalho que é pôr em relevo certas dinâmicas do processo decisório do coletivo investigado. Procurei mostrar como a partir de um terreno comum muito bem estabelecido e de uma questão política desafiadora foi possível avançar e construir alinhamentos e soluções de compromisso que, mesmo que tivessem exigido alguma renúncia, permitiram que todas as vozes fossem objeto de consideração e tivessem algum peso na construção dos arranjos, por um lado, e impediram que vozes dissonantes ou opiniões minoritárias fossem descartadas como voto vencido, por outro. Aliás, a própria ideia de votação sempre foi vista com desconfiança por alguns cidadanistas, embora ela não estivesse completamente ausente de suas práticas. A resolução sobre o ingresso da Raiz no PSOL foi produto de uma construção coletiva gradativa, mas precisava ainda contar com a anuência explícita de todos para ser legitimada ${ }^{37}$ e oficializada. Mas no lugar de uma votação direta, a proposta foi lida em voz alta como uma decisão coletiva (como em uma votação simbólica) e aqueles que se lhe opunham manifestaram a sua discordância livremente não se restringindo apenas à manifestação de desagrado com um sinal (levantar os braços, virar o polegar pra baixo ou seja lá o que for). Mesmo que, cada um dos três descontentes tenha resumido a sua decisão a uma frase - não podemos esquecer, no entanto, que já tinham debatido o assunto exaustivamente -, ainda assim fica evidente que, embora as três

37 Acredito que essa preocupação tinha mais a ver com uma necessidade de legitimar o processo decisório perante os integrantes da Raiz que não participaram da Teia do que com uma preocupação dos presentes em legitimar essas decisões para si mesmos. Essa suposição surgiu das inúmeras vezes que vi questionamentos a respeito de quando e como uma decisão teria sido tomada, principalmente no Loomio, o que, não raro, levava a desentendimentos. 
sentenças expressassem claramente a discordância, elas também indicavam positivamente que eles prosseguiam na sua trajetória como membros da Raiz.

A Teia Nacional foi encerrada com a reconfiguração da estrutura da Raiz (levando em consideração a sua recém-criada dimensão-partido) e a eleição dos componentes da Esfera, a sua instância executiva. Ao mesmo tempo em que o Ivan coordenava as falas - à medida que os presentes chegavam a pequenos alinhamentos em relação a nova estrutura do movimento -, ele fazia o esboço de um organograma a partir de suas sugestões em uma folha de papel pardo fixada em uma das paredes da sala. De início, propuseram a criação de um grupo para a dimensão-partido e outro para dimensão-movimento, com um porta-voz para cada um. A proposta foi, de imediato, criticada por criar instâncias circunscritas (caixinhas) desnecessariamente, quando bastariam dois porta-vozes atuando junto à coordenação para dar conta da função. $\mathrm{O}$ autor da primeira proposta disse não acreditar nesse arranjo, pois seria fundamental prever a substituição daqueles que não conseguissem executar as suas funções e que, além disso, seria preciso um líder para puxar os trabalhos a partir de um plano executivo. Segundo ele, a Raiz não funcionava pois lhe faltava liderança. A partir desse diagnóstico o debate se tornou bastante acirrado, com sucessivos embates em torno da polêmica ideia da necessidade de um líder em um coletivo que sempre procurou fazer da horizontalidade um princípio, um meio e um fim. Para uma parte dos presentes o problema da Raiz era, antes de tudo, de organização e um arranjo estrutural bem arquitetado, que funcionasse segundo regras bem definidas, seria suficiente para garantir o bom funcionamento do movimento. A posição contrária defendia que nada garantiria a existência do coletivo se as pessoas fossem deixadas a si, sem alguém que as coordenasse e cobrasse, o que remete às discussões do capítulo 2 sobre a confiança no caráter antientrópico de algumas instâncias, como as Coordenadorias e Grupos de Trabalho. Mas se ali a imagem preponderante da falta de uma força ordenadora era o caos, aqui, a falta de uma liderança conduziria, quase que naturalmente, à paralisia ou a inoperância. Mas isso se daria menos por uma incapacidade organizativa intrínseca (os agentes teriam a plena capacidade de se juntarem e realizar ações com sucesso) do que por uma suposta falta de senso de dever e responsabilidade que estaria às voltas com a ação voluntária. Mesmo aqueles a quem a ideia de liderança era, de saída, inaceitável, quando confrontados com a possibilidade bastante plausível (e empiricamente atestada) de alguém faltar com suas obrigações, mostraram-se mais receptíveis à ideia de alguém exercer o papel de coordenar e cobrar as pessoas. As discordâncias agora pareciam ser fruto dos diferentes entendimentos sobre o que seria cobrar as pessoas e, sobretudo, acerca do 
significado do conceito de liderança, ainda muito associado à ideia de um poder decisório monocrático. Era ainda preciso explicitar e negociar os sentidos que tornavam possível entrar em um acordo sobre o que seria um líder aceitável, que não atentasse contra os princípios democráticos da Raiz.

O final do debate foi marcado por uma aproximação entre o posicionamento lógica de empresa (que lhes permitiria sair da paralisia e fazer as coisas funcionar a partir de um plano de gestão proposto e implementado por um líder) e os anseios de igualdade política entre todos os participantes do movimento. Assim, ficou acordado que o líder deveria apenas colocar em prática o que teria sido decidido pelo coletivo, podendo propor uma metodologia de trabalho (sujeita à aprovação coletiva) e cobrar daqueles que não realizassem as ações a que se propunham. Independente do que foi colocado em prática efetivamente - que ultrapassou o período do trabalho de campo - fica evidente que essa solução foi acolhida porque ainda estava arraigado no espírito dos cidadanistas o dualismo metafísico que tem organizado a cosmologia política do ocidente e que coloca a política e a técnica em domínios ontologicamente distintos. Entretanto, tenho que reconhecer que, em vários momentos, li e ouvi críticas expressamente formuladas a essa divisão, principalmente quando estavam discutindo a questão ecológica. Pois mesmo que, nesse modo de pensar, a técnica estivesse subordinada à política, ainda havia uma separação constitutiva fundamental que permitiria a um modelo empresarial colocar em bom funcionamento o mecanismo pesado e ineficiente da política. A ideia, tributária de certo hilemorfismo, de que o líder deve apenas executar um plano decidido previamente pela ação política coletiva, supõe em larga medida que é possível a pura execução prática ou que o líder é, ou deveria ser, uma extensão ou encarnação da vontade coletiva. A exemplo do que vimos no capítulo anterior, considerar a tarefa de colocar em prática um plano ou de organizar um coletivo como ações meramente executivas, administrativas etc., é também uma forma de colocar toda uma infinidade de pequenas decisões e acontecimentos para fora do âmbito da ação e da reflexão coletiva, erigindo fronteiras entre o político e o não político que, a despeito de serem sempre problemáticas e sujeitas à implosão, podem produzir efeitos políticos opostos àqueles desejados.

Entretanto, ao aceitar a figura da liderança e da representação a Raiz estava fazendo um pouco mais do que apenas atualizar as figuras políticas do modelo político-representativo dominante. Ela estava colocando em questão a oposição entre a participação (direta) e a representação e que tem sido traduzida - por um discurso muito influente dentro da esquerda -, na oposição entre atividade e passividade (ZIZEK 2011:128). Pois para os cidadanistas, politizar não 
significava participar ativamente em tudo, aliás, como vimos no capítulo anterior, essa lhes seria uma impossibilidade empírica. Mais importante do que a participação efetiva de todos em todas as atividades ou etapas do processo decisório, seria a abertura das instâncias democráticas para a participação voluntária e intervenção dos sujeitos. A existência de uma liderança ou um representante não parecia ser um grande problema desde que houvesse a possibilidade de rever e obstaculizar as suas decisões e que a atividade da liderança e o processo decisório fossem pautados pela transparência. Vimos no capítulo 2 que esse sentido de transparência ultrapassa a ideia corrente de 'deixar-ver' e aponta para uma noção mais ativa de transparência, na qual deveria haver a busca contínua de meios para tornar as ações da liderança e os processos decisórios abertos à monitoração e à inclusão participativa. Embora essa ideia de transparência ativa nunca tenha sido conceitualizada dessa forma, os predicados que nela estão subsumidos sempre se fizeram presentes nas dissensões e nas reflexões dos cidadanistas sobre suas práticas políticas.

A confiança também cumpria um papel fundamental na aceitação e legitimação da liderança. Se, por um lado, a ideia (abstrata) da liderança gerou um debate acalorado entre os cidadanistas, a sugestão (concreta) do Ivan para ser líder contou com a concordância imediata e entusiasmada de todos (aliás, um dos poucos momentos de consenso instantâneo, sem quaisquer mostras de hesitação ou ressalva). Os cidadanistas sempre reconheceram que a confiança estava diretamente relacionada a relações de afeto e à convivência, fatores mais associados aos relacionamentos presenciais. Isso explica, de certa forma, por que a obsessão com transparência era muito maior nas relações digitais. Até certo ponto, a ausência de confiança poderia ser compensada com transparência e vice-versa. $\mathrm{Na}$ verdade, nas práticas digitais a relação entre as duas parecia, antes, genética do que uma relação entre variáveis independentes (que poderiam ser substituídas uma pela outra em função dos seus efeitos semelhantes), na medida em que a transparência também geraria confiança (e a sua falta, desconfiança), como no caso de alguns ciberagentes que se empenhavam em manter todos informados, que chamavam os seus correligionários para participarem das discussões e que insistiam em manter as votações no Loomio abertas por mais tempo (para mais pessoas participarem), posturas que os faziam conquistar grande respeito e admiração.

Democracia, consenso, participação e representação são apenas alguns dos termos onipresentes nas práticas discursivas dos cidadanistas e que têm, há séculos, colocado em movimento o pensamento político do ocidente. Desse modo, pode-nos causar certa estranheza um coletivo que propunha uma nova forma de fazer política acionar um conjuntos de categorias que nos soam tão familiares. Mas quando olhamos mais de perto logo vemos a multiplicação incessante de 
pequenos deslocamentos em relação às nossas definições categoriais, a torção ou mesmo a diluição de dualismos enraizados em nossa cosmologia política (ainda que, algumas vezes, eles estivessem prontos para ressurgir) e inversão de valores de termos e recombinações em novos arranjos que se mostravam verdadeiros atos de 'bricolage' política. Penso que essa e outras experiências políticas têm muito a nos ensinar, não como modelos a serem seguidos - algo que a Raiz nunca se propôs mas como práticas que nos fazem re-pensar os nossos conceitos analíticos e políticos e, por isso, funcionam como dispositivos de abertura para novas possibilidades existenciais. 


\section{CONCLUSÃO}

À guisa de conclusão, gostaria de chamar atenção mais uma vez para o caráter inacabado e em permanente (re)construção da Raiz Movimento Cidadanista e do seu projeto político. Se é verdade que a literatura política e socioantropológica mostra que a maior parte dos coletivos políticos acredita que o porvir lhes reserva mudanças promissoras, a Raiz fez da sua abertura à transformação, o motor da sua existência, em movimentos que, ora se satisfaziam com o plantio de sementes que iriam germinar e dar frutos em um amanhã mais promissor, ora se lançavam ao desafio de realizar o futuro no tempo do agora (o que, sem dúvida, aponta para a limitação das nossas categorias temporais de passado, presente e futuro para pensar essas iniciativas políticas). Espero ter deixado claro para os leitores, assim como ficou claro para mim, de que estamos lidando com pensamentos em movimento (e há pensamento que não esteja?) e, por isso, não vos devem causar estranheza as contradições, as incoerências e conflitos a que tal projeto político estava sujeito, o que nada diz acerca da sua pertinência ou sobre o seu valor como objeto legítimo de pensamento e de inspiração política. E isso me leva a outro aspecto dessas práticas que também me parece fundamental e pode fazer com que reavaliemos muitas ações que, sob determinados aspectos, poderíamos concebê-las como incoerentes: trata-se do caráter profundamente experimental e criativo dessas práticas políticas. Os cidadanistas assumiam com orgulho as suas inspirações libertárias e indígenas, mas tinham plena consciência de que o modelo político que almejavam nunca existiu historicamente e precisava ser construído por meio de múltiplas tentativas, erros e transformação contínua. Nesse sentido, tudo seria provisório, revogável e sujeito à avaliação e não deveria haver grande problema em voltar atrás. É por isso que certas atitudes taxadas de puristas eram alvo constante de severas críticas por parte de muitos cidadanistas, como presenciei em inúmeros momentos, desde os debates na plataforma Loomio. Os cidadanistas entendiam que, muitas vezes, seria necessário compor com os escombros de um sistema social e político devastado, com lógicas que, em muitos sentidos, entravam em contradição com os seus princípios basilares e sabiam dos perigos de serem absorvidos por esse sistema podre. A questão política que gerava tanta inquietação no dia-a-dia desses sujeitos era então: como compor com esse sistema sem se deixarem corromper por suas lógicas e suas práticas perversas? Esse "como" nunca foi de modo algum um ponto pacífico, de fácil consenso, e muitos desistiram de prosseguir no coletivo por se 
decepcionarem com o desvio do caminho político que esperavam. Mas se a transformação e a provisoriedade poderiam ser consideradas características fundamentais do Movimento Cidadanista, havia algo que figurava no seu imaginário com a marca da continuidade e da permanência: os seus princípios fundadores, lapidados com esmero e sentimento no seu manifesto fundador, a Carta Cidadanista. Mais do que uma ideologia política, esses princípios representavam para os cidadanistas, uma ética, uma filosofia e um modo de dar sentido a sua forma de 'ser-no-mundo', a ponto de serem vistos como uma perfeita síntese dos aspectos mais nobres das nossas raízes identitárias e, nesse sentido, podem ser pensados como uma espécie de 'descoberta-invenção'. Por isso, para alguns, seria mais fácil conceber a extinção da Raiz do que imaginar o fim do cidadanismo (esse encontro primoroso entre o Bem Viver, o Ubuntu e o Ecossocialismo) e não é à toa que, mesmo pessoas egressas do movimento ou que ameaçavam deixá-lo, declaravam que continuariam seguindo os princípios da Carta Cidadanista, mesmo estando fora da Raiz. O próprio Mandato Cidadanista, visto por grande parte dos seus membros como uma ação prática da Raiz, foi um bom exemplo de que, para além da ideia de grupo ou organização, esses princípios eram percebidos como componentes fundamentais da subjetividade política desses agentes e, por isso, poderiam acompanhá-los onde quer que eles estivessem. Não me parece que meus interlocutores ignorassem a possibilidade desses princípios serem interpretados diferentemente em suas reflexões e em suas distintas situações enunciativas. No entanto, persistia a ideia de era preciso estudá-los mais a fundo, de que um mergulho sistemático em suas fontes seria capaz de dotá-los da capacidade de compreender a sua essência e tornar as suas ações cotidianas mais próximas do espírito que os animava em seus contextos sociais de origem.

Quando vi a primeira manifestação do movimento passe livre em 2013, não poderia imaginar onde ela nos levaria e, muito menos, que ela poderia ter efeitos tão perversos em relação às intenções e sonhos daqueles jovens insurgentes. Mesmo que, enquanto cientistas sociais, tenhamos consciência da conjunção complexa de fatores que nos trouxeram à atual situação política e olhemos com desconfiança para os modelos explicativos que recorrem a causalidades mecânicas e variações concomitantes de poderosas variáveis, não podemos deixar de pensar sobre o que teria acontecido se, por algum motivo, aquele movimento não tivesse irrompido naquele momento. Estou certo de que, muito provavelmente, essa dissertação, - ou qualquer outra dissertação no campo da Antropologia da Política - nunca viria a ser por mim escrita. Olhando para o que se passou nas ruas em 2013, para os acontecimentos políticos dos últimos anos e para esses três conturbados anos de mestrado, também não consigo deixar de pensar em como determinados acontecimentos nos 
colocam em movimento e transformam inexoravelmente a nossa existência. Contudo, os meus interlocutores, verdadeiros mestres na arte da política, se não me ensinaram, certamente fixaram em meu espírito de uma vez por todas, a cláusula adicional que condiciona a força transformadora do evento a uma postura de abertura, a um deixar ser afetado por ele. Evidentemente, essa é uma aventura política, intelectual, afetiva e moral imprevisível e isenta de quaisquer garantias, mas o fato inelutável da nossa condição imprime, no mais íntimo de nosso ser, a certeza de que, de um modo ou de outro, é preciso viver e que toda vida é política. 


\section{REFERÊNCIAS}

AGAMBEN, Giorgio. Deus não morreu. Ele tornou-se dinheiro (Entrevista concedida a Peppe Salvà). Revista IHU Online, 30 de agosto de 2012. Disponível em: $<$ http://www.ihu.unisinos.br/noticias/512966>. Acesso em 15 de junho de 2016.

AGIER, Michel. Os saberes urbanos da antropologia. In: . Antropologia da cidade: lugares, situações, movimentos. São Paulo: Terceiro Nome, 2011. p. 59-88.

ALONSO, Angela. As teorias dos movimentos sociais: um balanço do debate. Lua Nova, v.76:4986, 2009.

ALVES, Daniel. Aportes teórico-metodológicos para o estudo de redes transnacionais de líderes pentecostais e carismáticos. Horizontes Antropológicos, 18 (37), 2012. p. 45-71. Disponível em: $<$ https://dx.doi.org/10.1590/S0104-71832012000100003>. Acesso em 19 de agosto de 2016.

ANDRION, Roseli. O que as mudanças no Instagram podem significar para os usuários? 17 de julho de 2019. Disponível em:

$<$ https://olhardigital.com.br/noticia/o-que-as-mudancas-no-instagram-podem-significar-

para- os-usuarios/88080>. Acessado em: 13 de abril de 2019.

BÁDUE, Ana Flávia. A nebulosa do decrescimento. Um estudo sobre as contradições das novas formas de fazer política. Dissertação (Mestrado em Antropologia Social). Programa de PósGraduação em Antrop. Social. Faculdade de Filosofia, Letras e Ciências Humanas. São Paulo: 2012.

BALDIN, Nelma; MUNHOZ, Elzira Bagatin. Snowball: uma ténica metodológica para pesquisa em educação ambiental comunitária. Comunicação apresentada no X Congresso Nacional de Educação - Educere, na Pontifícia Universidade Católica do Paraná em novembro de 2011. Disponível em: < http://educere.bruc.com.br/CD2011/pdf/4398_2342.pdf>. Acesso em 10 de agosto de 2016.

BALZA, Guilherme. Após rachar PSB, apoio de Marina a Aécio provoca saída de membros da Rede. Portal Uol Eleições. 13 de outubro de 2014. Disponível em:

$<$ http://eleicoes.uol.com.br/2014/noticias/2014/10/13/apos-rachar-psb-apoio-de-marina-aaecio-provoca-saida-de-membros-da-rede.htm>. Acesso em 12 de setembro de 2016.

BARAD, Karen. Meeting the Universe Halfway: Quantum Physics and the Entanglement of Matter and Meaning. Durham, NC : Duke University Press, 2007. 
BAYON, Denis; FLIPO, Fabrice; SCHNEIDER, François. La Décroissance, 10 questions pour comprendre et en débattre. Paris: La Découverte, 2010.

BBC Brasil. Protestos globais crescem com perda de fé na política e no Estado. 23 de junho de 2013. Disponível em: <http://www.bbc.com/portuguese/noticias/2013/06/130623_protestos_ pressreview_bg.shtml>. Acesso em 13 de setembro de 2016.

BBC NEWS. Instagram 'worst for young mental health'. 19 May 2017. Disponível em: $<$ https://www.bbc.com/news/health-39955295>. Acessado em: 13 de abril de 2019.

BOGOST, Ian. Alien Phenomenology, or What It's Like Be a Thing (Posthumanities). Minneapolis: University of Minnesota Press, 2012.

BOELLSTORFF, Tom. For whom the ontology turns: theorizing the digital real. Current Anthropology 57(4), 2016. Disponível em:

<www.journals.uchicago.edu/doi/full/10.1086/687362>. (acessado em dezembro de 2017).

BRYANT, Levi; SRNICEK, Nick and HARMAN, Graham. 2011. The Speculative Turn: Continental Materialism and Realism. Melbourne: re.press.

BUTLER, Judith. "Bodies In Allience And The Politics Of The Street", apresentação oral em setembro de 2011 em Veneza, no evento The State of Things, organizado por Office for Contemporary Art de Noruega (OCA). 2011. Disponível em: < http://eipcp.net/transversal/1011/butler/en/print >. Acesso em 8 de agosto de 2016.

CHARBONNIER, Pierre; SALMON, Gildas \& SKAFISH, Peter. "Introduction” In: CHARBONNIER, Pierre; SALMON, Gildas \& SKAFISH, Peter (Eds.). Comparative Metaphysics: Ontology after Anthropology. London, New York, Rowman \& Littlefield, 2017.

COSTA, Dom Henrique Soares da. Teimam em gritar: a Teologia da Libertação está viva! Disponível em: <http:/www.domhenrique.com.br/index.php/analises/956-teimam-emgritar- a-teologia-da-libertacao-esta-viva> Acessado em 26 de maio de 2017.

CROFT, John. Dragon Dreaming:a manual for personal empowerment, community building and envronmental action. Perth: Gaia Foundation,1991.

DANOWSKI, Débora; VIVEIROS DE CASTRO, Eduardo. Há mundo por vir? Ensaio sobre os medos e os fins. Desterro [Florianópolis]:Cultura e Barbárie/Instituto Socioambiental, 2014. DELEUZE, Gilles; GUATTARI, Félix. Mil platôs: capitalismo e esquizofrenia 2, vol. 3. 2a ed. São Paulo: Editora 34, 2012. 
DESMOND TUTU, Mike Nicol. Croire - inspirations et paroles de Desmond Tutu. Acropole Belfond, 2007.

DI GIOVANNI, Julia Ruiz. Seattle, Praga, Gênova: política anti-globalização pela experiência da ação de rua. Dissertação (Mestrado em Antropologia Social). Programa de Pós-Graduação em Antropologia Social. Faculdade de Filosofia, Letras e Ciências Humanas. Departamento de Antropologia da Universidade de São Paulo. São Paulo: 2008.

DI GIOVANNI, Julia Ruiz. “Artes de abrir espaço. Apontamentos para a análise de práticas em trânsito entre arte e ativismo", Cadernos de Arte e Antropologia, Vol. 4, No 2. 2015. p. 13 27.

DRAGON DREAMING BRASIL (Comunidade) (Ebook). Guia prático Dragon Dreaming: Uma introdução sobre como tornar seus sonhos em realidade através do amor em ação. Janeiro de 2014. Disponível em: <http://dragondreamingbr.org>. Acessado em 03 agosto de 2019.

DUSSEL, Enrique. Teologia da Libertação - Um panorama do seu desenvolvimento. Petrópolis: Vozes, 1999.

EMOTICON. In: WIKIPÉDIA, a enciclopédia livre. Flórida: Wikimedia Foundation, 2019.

Disponível em: $<$ https://pt.wikipedia.org/w/index.php?title=Emoticon\&oldid=54804724>. Acessado em: 13 abr. 2019.

EXPOSITO, Marcelo.“Todo mi cuerpo recuerda: desorden festivo, mutación subjetiva y devenir revolucionario.” in Playgrounds. Reinventar la plaza (catálogo) editado por Museu Reina Sofía. Madrid: Museo Nacional Centro de Arte Reina Sofía/Ediciones Siruela. 2014. p.218231.

FORTES, Meyer \& EVANS-PRITCHARD, E. African political systems. Oxford: Oxford University Press, 1940.

FORUM (Portal). Coletivo Avante define nome de novo partido. 17 de março de 2015. Disponível em: < http://www.revistaforum.com.br/blog/2015/03/coletivo-avante-define-nome-de-novopartido/>. Acesso em 12 de setembro de 2016.

FUKUYAMA, Francis. Fim da história e o último homem. Rio de Janeiro: Rocco, 1992.

GALINIER, Jacques \& MOLINIÉ, Antoinette. Les néo-Indiens, une religion du IIIeme millénaire. Paris: Odile Jacob, 2006. 
GASPER, Phil. Karl Marx, radical environmentalist. SocialisWorker.org. June 4, 2014. Disponível em: $<$ http://socialistworker.org/2013/06/04/karl-marxs-environmentalism> Acesso em 07 de maio de 2019.

GELL, Alfred. Art and Agency: An Anthropological Theory. Oxford: Clarendon Press, 1998.

GERBAUDO, Paolo. The Mask and the Flag: Populism, Citizenism and Global Protest. Oxford: Oxford University Press, 2017.

GLUCKMAN, Max. Análise de uma situação social na Zululândia moderna. In: FELDMANBianco, Bela (org.). Antropologia das sociedades contemporâneas: métodos. São Paulo: Unesp (2a edição), 2010. p. 227-344.

GOLDMAN, Márcio; SILVA, Ana Claudia Cruz. Por que se perde uma eleição? In: BARREIRA, Irlys; PALMEIRA, Moacir. Candidatos e Candidaturas. Enredos de Campanha Eleitoral no Brasil. Anablume/UFC:São Paulo, 1998.

GOLDMAN, Márcio. Segmentaridades e movimentos negros nas eleições de Ilhéus. Mana. Estudos de Antropologia Social [online]. vol.7, n.2, 2001. p. 57-93.

HENARE, Amiria, HOLBRAAD, Martin and WASTELL, Sari (eds.). 2007. Thinking Through Things: Theorising Artifacts Ethnographically. London: Routledge.

HERZFELD, Michael.Cultural Intimacy. Social Poetics in the Nation-State. New York/London: Routledge, 1996.

HOLBRAAD, Martin; PEDERSEN, Morten Axel. The Ontological Turn: an Anthropological Exposition. Cambridge: Cambridge University Press, 2017.

KITSCHELT, H. Movements Parties. In: KATZ, R.; CROTTY, W (Org.). Handbook of Party Politics. London - UK, Thousand Oak - US, New Delhi - IN: SAGE Publications, 2003.

KNOX , Hannah; WALDORF, Antonia. Is there an ontology to the digital? In: Cultural Anthropology website, 2016. Disponível em: <http://culanth.org/conversations/17theorizing-the-contemporary>. Acessado em dezembro de 2017.

KOVEL, Joel; LÖWY, Michael. An ecosocialist manifesto, Paris, sept. 2001. Disponível em: $<$ http://members.optushome.com.au/spainter/Ecosocialist.html $>$. Acesso em maio de 2019.

LATOUCHE, Serge. Pequeno tratado do crescimento sereno. São Paulo: Martins Fontes, 2009. LATOUR, Bruno. Jamais fomos modernos. Rio de Janeiro: Editora 34, 1994.

LATOUR, Bruno. Pandora's Hope: Essays on the Reality of Science Studies. Cambridge, MA: Harvard University Press, 1999. 
LATOUR, Bruno. Políticas da natureza. Bauru: EDUSC, 2004.

LATOUR, Bruno. Reassembling the Social: An Introduction to Actor-Network-Theory. Oxford: Oxford University Press, 2005.

LATOUR, Bruno. Face à Gaïa: huit conférences sur le nouveau regime climatique. Paris: La Découverte, 2015.

LÉVI-STRAUSS, Claude. Introduction: Histoire et Ethnologie. In: Anthropologie structurale, Paris: Plon, 1958 (1949). p. 3-33.

LÉVI-STRAUSS, Claude. O pensamento selvagem. Campinas: Papirus, 2009.

LÖWY, Michael. Ecologia e socialismo. São Paulo: Cortez, 2005.

MARQUES, A. C.; COMERFORD, J. C.; CHAVES, C. Traições, intrigas, fofocas e vinganças.

Notas para uma abordagem etnográfica do conflito. In: MARQUES, A.C.(Org.). Conflitos, política e relações pessoais. Campinas: Pontes/CNPq/UFC, 2007. p. 27-55.

MAUMUS, Johan. Les premiers smileys, une blague de typographe. 08 de junho de 2017.

Disponível em:

$<$ https://www.graphiline.com/article/26092/premiers-smileys-une-blague-de-typographe> Acessado em: 13 de abril de 2019.

MITCHELL, Clyde (org.) The concept and use of social network. In: Social networks in urban situations. Manchester: Manchester University Press, 1969. p. 1-50.

MITCHELL, Clyde. Social networks. Annual Review of Anthropology, v.3, 1974. p.279-299.

Disponível em: <http://links.jstor.org/sici?Sici=00846570\%281974\%292\%3A3\%3C279\% 3ASN\%3E2.0.CO\%3B2-Q>. Acesso em:15 de agosto de 2015.

MCKENZIE, Hamish. Occupy Democracy: Loomio attempts to re-invent group decision-making... as a co-op. May 2, 2013. Disponível em:

$<$ https://pando.com/2013/05/02/occupy-democracy-loomio-attempts-to-re-invent-groupdecision-making-as-a-co-op/>. Acessado em 15 de julho de 2018.

MOORE, Jason. Capitalism in the Web of Life. New York: Verso, 2015.

MOORE, Jason; PARENTI, Christian. Anthropocene or capitalocene? nature, history, and the crisis of capitalism. Oakland, CA: PM Press, 2016.

MORAES, Alana; TIBLE, Jean. “Quando novos personagens entram em cena? (Introdução).” In: Cartografias da Emergência: Novas Lutas no Brasil. São Paulo: Fundação Friedrich Ebert (FES), 2015. 
MOTA, Camilla Veras. Brasileiro abandonou 'máscara' de cordial e assumiu sua intolerância, diz Lilia Schwarcz. BBC News Brasil, 1 de junho de 2009. Disponível em:

$<$ https://www.bbc.com/portuguese/brasil-48424619>. Acesso em 10 de setembro de 2019.

ORTELLADO, Pablo. Os protestos de junho: entre o processo e o resultado. In: JUDENSNAIDER, Elena; LIMA, Luciana; ORTELLADO, Pablo; POMAR, Marcelo. 20 centavos: a luta contra o aumento. São Paulo: Editora Veneta, 2013.

PIKETTY, Thomas. O capital no século XXI. São Paulo: Intrínseca, 2014.

Raiz. Carta Cidadanista. 2015. Disponível em: < < <ttp://www.raiz.org.br/media/uploads/ documentos_da_raiz/raiz_carta-cidadanista2.pdf>. Acesso em 10 de setembro de 2017.

POVINELLI, Elizabeth. Geontologies: a requiem to late liberalism. Durham: Duke Press, 2016.

RAIZ. Carta Cidadanista. 2015. Disponível em:

$<$ http://www.raiz.org.br/media/uploads/documentos_da_raiz/raiz_carta-cidadanista2.pdf $>$. Acessado em 10 de setembro de 2017.

RAIZ. Consenso Progressivo. 2015. Disponível em: $<$ http://www.raiz.org.br/consensoprogressivo>. Acessado em 10 de setembro de 2017.

RAIZ. Guia para Consenso Progressivo. 2015. Disponível em:

$<$ http://www.raiz.org.br/media/uploads/2016/02/23/consensov1.pdf > . Acessado em 13 de abril de 2018.

RAIZ. Teia Digital - Loomio, 2017. Disponível em: < https://www.loomio.org/g/OBJDMnPl/teiaraiz>. Acessado em 08 de dezembro de 2017.

Raiz - Movimento Cidadanista (Grupo de Facebook). Disponível em:

$<$ https://www.facebook.com/groups/RaizMovimentoCidadanista/> . Acesso em 08 de dezembro de 2017.

Raiz - Movimento Cidadanista (Fanpage de Facebook). Disponível em:

$<$ https://www.facebook.com/RaizMovimentoCidadanista/>. Acesso em 08 de dezembro de 2017.

RAPOSO, Paulo. "Artivismo: articulando dissidências, criando insurgências", Cadernos de Arte e Antropologia, Vol. 4, No 2. 2015, p. 3-12.

RIBEIRO, Claudio de Oliveira. A Teologia da Libertação Morreu? Aparecida: Santuário, 2010.

ROCKSTRÖM, Johan; STEFFEN, Will; NOONE, Kevin et al. A safe operating space for humanity. Nature 461, 472-475, 23 sept. 2009. Disponível em: <http://www.nature.com/nature/journal/ v461/n7263/full/461472a.html>. Acessado em: 17 maio de 2019. 
SANCHOTENE, Carlos. O uso de Emoticons nas Fanpages de Folha de São Paulo e Estadão. In: Dispositiva - Revista do Programa de Pós-Graduação em Comunicação Social, Vol.6 (Abordagens Semióticas, Consumo, Tecnologias), n.10, 2017.

SAFATLE, Vladimir. A esquerda que não teme dizer seu nome. São Paulo: Três estrelas, 2012.

SANTOS, Boaventura de Sousa. A onda Podemos. Agência Carta Maior - Sítio de notícias, 18/11/2014. Disponível em <http://cartamaior.com.br/?/Coluna/A-onda-Podemos/32260>. Acesso em: 07/08/2018

SIMMEL, Georg. A natureza sociológica do conflito. In: Moraes Filho, Evaristo (org.), Simmel. São Paulo: Ática, 1983.

SOUZA, Cláudio A. Pensar a democracia: desafios e reflexões sobre a representação política na contemporaneidade. Revista Pindorama, v. 1, 2012. p. 1-21.

STENGERS, Isabelle. Au temps des catastrophes: resister à la barbarie qui vient. Paris: La Découverte, 2009.

STENGERS, Isabelle. "La propuesta cosmopolítica". Revista Pléyade 14, 2014. p. 17-41.

SZTUTMAN, Renato. Reativar a feitiçaria e outras receitas de resistência - pensando com Isabelle Stengers. Revista do Instituto de Estudos Brasileiros, Brasil, n. 69, p. 338-360, abr. 2018.

TURNER, Victor. "Frame, Flow and Reflection: Ritual and Drama as Public Liminality". Japanese Journal of Religious Studies, 6 (4), 1979. p. 465-499.

WHYTE, William Foote. Sociedade de esquina. Rio de Janeiro: Jorge Zahar Editora, 2005.

ZIZEK, Slavoj. Primeiro como tragédia, depois como farsa. São Paulo: Boitempo, 2011. 